\title{
Anna-Liisa Ojala
}

\section{Vaihtoehtoisuutta ja valtavirtaisuutta}

Tutkimus suomalaisten lumilautailijoiden uria raamittavista asenteista, olosuhteista ja resursseista
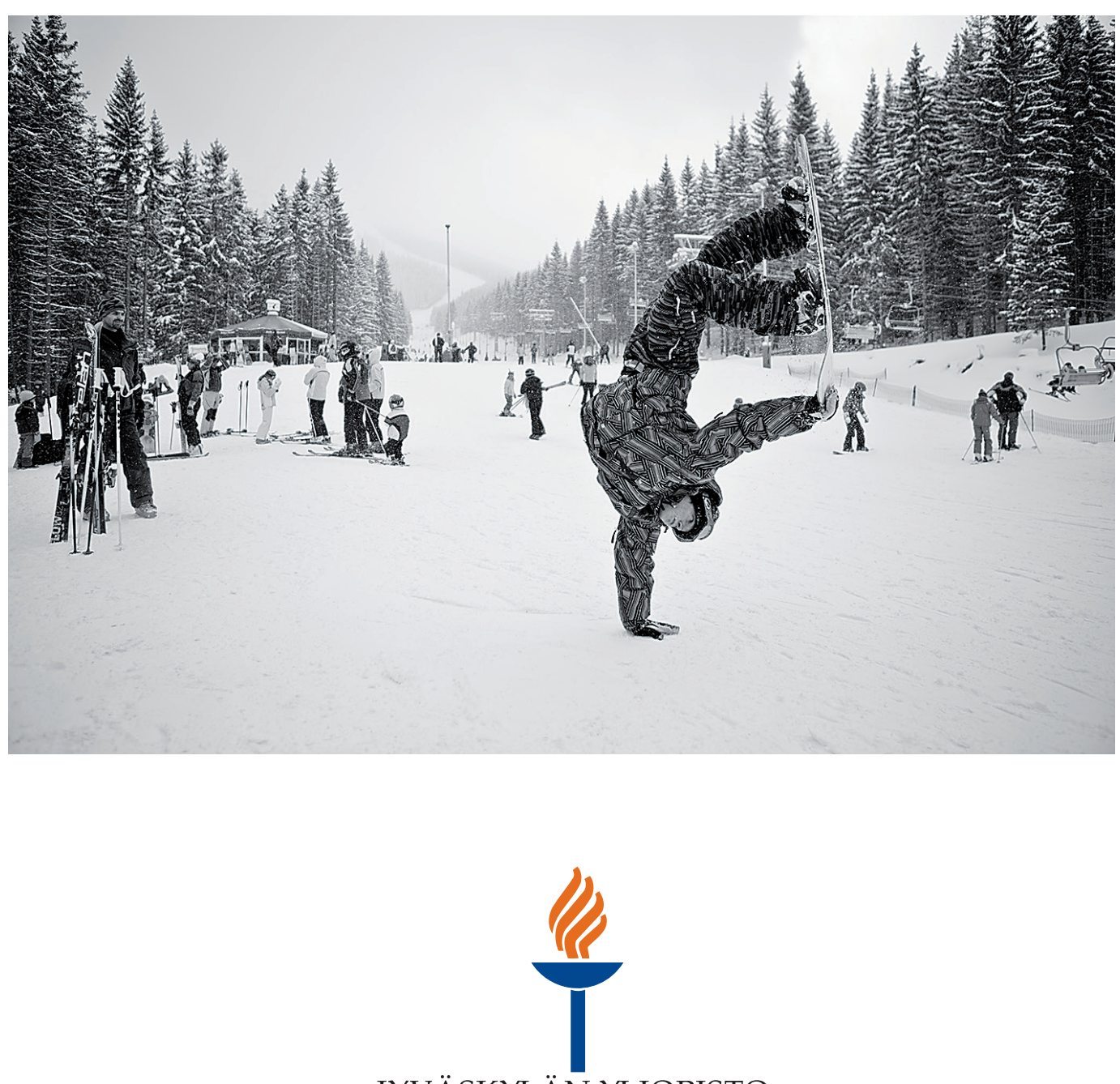


\section{Anna-Liisa Ojala}

\section{Vaihtoehtoisuutta ja valtavirtaisuutta \\ Tutkimus suomalaisten lumilautailijoiden uria raamittavista asenteista, olosuhteista ja resursseista}

Esitetään Jyväskylän yliopiston liikuntatieteellisen tiedekunnan suostumuksella julkisesti tarkastettavaksi yliopiston Liikunnan salissa L303 huhtikuun 24. päivänä 2015 kello 12.

Academic dissertation to be publicly discussed, by permission of the Faculty of Sport and Health Sciences of the University of Jyväskylä, in the Liikunta building, auditorium L303, on April 24, 2015 at 12 o'clock noon.

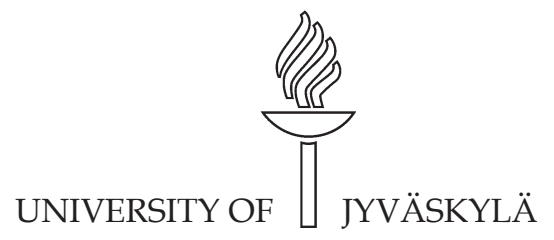

JYVÄSKYLÄ 2015 


\section{Vaihtoehtoisuutta ja valtavirtaisuutta}

Tutkimus suomalaisten lumilautailijoiden uria raamittavista asenteista, olosuhteista ja resursseista 


\section{Anna-Liisa Ojala}

\section{Vaihtoehtoisuutta ja valtavirtaisuutta \\ Tutkimus suomalaisten lumilautailijoiden uria raamittavista asenteista, olosuhteista ja resursseista}

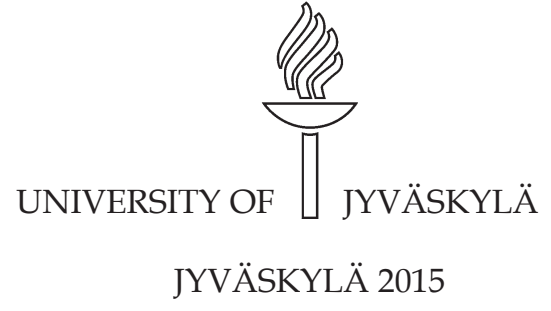




\section{Editors}

Jarmo Liukkonen

Department of Sport Sciences: Physical Education and Social Sciences of Sport,

University of Jyväskylä

Pekka Olsbo, Timo Hautala

Publishing Unit, University Library of Jyväskylä

Kannen kuva: Sami Tuoriniemi

URN:ISBN:978-951-39-6115-2

ISBN 978-951-39-6115-2 (PDF)

ISBN 978-951-39-6114-5 (nid.)

ISSN 0356-1070

Copyright @ 2015 , by University of Jyväskylä

Jyväskylä University Printing House, Jyväskylä 2015 


\author{
ABSTRACT \\ Ojala, Anna-Liisa \\ Alternative and mainstream: a study on the attitudes, circumstances and resources \\ framing the careers of Finnish freestyle snowboarders. \\ Jyväskylä: University of Jyväskylä, 2015, 103 p. \\ (Studies in Sport, Physical Education and Health \\ ISSN 0356-1070; 219) \\ ISBN 978-951-39-6114-5 (nid.) \\ ISBN 978-951-39-6115-2 (PDF)
}

Action sports such as snowboarding, skateboarding, BMX-bicycling and parkour are attracting an increasing number of participants, especially among young people. This qualitative study makes use of five research papers to examine Finnish freestyle snowboarders' access to the field of professional freestyle snowboarding. The study provides an overview of a field in which goal-directed sports meet the versatility and expressional methods of youth cultures as well as the commercial potential of the entertainment and media industries.

The primary data of the study included semi-structured interviews with Finnish professional and semi-professional snowboarders (19 male, 2 female, 17-31 years) and their managers (4 personal managers, 5 sponsors' team managers). During the research process I also utilized previous studies of action sports and follow-up questions for the informants. The data was transcribed, coded and themed according to each research question.

The findings of this study indicate that the field of professional freestyle snowboarding comprises two subfields: the competitive snowboarding sub-field and the snowboarding film and magazine sub-field. The organization models emphasized in the two fields differ greatly from one another and determine the opportunities for selfexpression in each field. Moreover, this study suggests that the media is structurally omnipresent in sport-related youth subcultures. Different forms of media have traditionally played different roles in the maintenance of the snowboarding culture. Furthermore, the study showed that in snowboarding's uncertain and rapidly changing circumstances, Finnish snowboarders value their peers and mentors more than coaches.

Although snowboarding is an Olympic sport, it does not conform to traditional sporting cultures. According to this study, a snowboarder ought to possess physical prowess, but sporting skills and success in competitions alone are not sufficient attributes to obtain good sponsorship contracts. The snowboarder also has to fit the image of the sponsoring brand and be respected among his or her peers in order to secure a career. Moreover, the study identified a career path which differs from those in traditional sports; some snowboarders are cultural producers who gather the necessary knowledge, actors and resources around them and build media productions around their snowboarding skills. Although snowboarding competitions continue in the goaldriven traditions of modern sports, the diversity and versatility of snowboarding styles and the array of goals within the sport allow snowboarders to construct their identities in more creative ways than athletes in modern sports.

Keywords: snowboarding, action sports, youth cultures, professional sports, coaching 
Anna-Liisa Ojala

Department of Sport Sciences,

University of Jyväskylä

PL 35, 40014 Jyväskylän Yliopisto

ojala.annaliisa@gmail.com

Supervisors

Hannu Itkonen

Department of Sport Sciences

University of Jyväskylä

Päivi Harinen

Department of Social Sciences

University of Eastern Finland

Holly Thorpe

Department of Sport and Leisure Studies

University of Waikato

\section{Reviewers}

Kimmo Jokinen

Family Research Centre

University of Jyväskylä

Stig Söderholm

School of History, Culture and Arts Studies

University of Turku

Opponents

Vesa Puuronen

Department of Educational Sciences and

Teacher Education

University of Oulu 


\section{ESIPUHE}

Syksyllä 2010 astuin sisään Professori Itkosen työhuoneeseen keskustellakseni mahdollisista jatko-opinnoista. En ollut suorittanut urapolkuni aikana ainoatakaan Liikuntatieteellisen tiedekunnan kurssia. Itkonen tulkitsi taustani monitieteisyydeksi ja kannusti aloittamaan.

Matkan varrella Professori Itkonen on muuttunut Hannuksi, mutta kannustus ja luottamus ovat säilyneet. Sain rinnalleni valmentajan, joka ei ole tuputtanut näkemyksiään, vaan on mahdollistanut, kyseenalaistanut ja tukenut. Aivan kuten totesin tutkimuksessani hyvän valmentajan toimivan. Olen tästä valmennussuhteesta äärimmäisen kiitollinen.

Urapolkuani ovat tasoittaneet myös kaksi muuta ohjaajaa: Päivi Harinen ja Holly Thorpe. Kummankin tuki ja ohjeet ovat tulleet tarpeeseen ja jouduttaneet matkantekoa. Heidän lisäkseen tahdon kiittää oikolukija Stacy Blythiä, jonka kanssa olemme nauraneet monet naurut artikkelieni, abstraktieni, yhteenvetojeni ja konferenssidiojeni parissa. Ilman Stacyn ammattitaitoa, tarkkuutta ja joustavuutta englanninkieliset kolleegani olisivat nauraneet jopa enemmän kuin me hassunperäisten [sic] sanavalintojeni vuoksi.

Artikkeliväitöskirjaa tehneet muistavat varmasti hyvin sen tunteen, kun vertaisarvioijat iskevät kommenteillaan kapuloita rattaisiin, mutta palaute pitäisi pysytyä näkemään matkaa jouduttavana. Jos saisin tietooni ensimmäisen artikkelini toisen vertaisarvioijan, lähettäisin hänelle kimpun kukkia. On suuri taito osata asettaa sanansa kunnioittavasti ja rakentavasti varsinkin silloin, kun valtasuhde on niin ilmeinen, mitä väitöskirjan vertaisarviointiprosesseissa välttämättä on. Tämän taidon olivat omaksuneet myös tutkimukseni esitarkastajat, Stig Söderholm ja Kimmo Jokinen sekä pari muuta artikkelieni arvioijaa ja editoria. Suurkiitos heille lempeästä asenteesta.

Urheiluun liittyvällä urapolulla myös organisaatiot ja instituutiot ovat keskeisessä asemassa. Tahdon kiittää Pauli Rintalaa ja Kalervo Ilmasta sekä liikunnan loistavaa työyhteisöä hyvän työilmapiirin mahdollistamisesta. Teidän kanssanne on ollut mukava kasvaa ja kehittyä. Jatko-opintoseminaarilaisille ja Pilvikki Heikinaro-Johanssonille kiitokset matkaseurasta ja ohjeista. Esa Nykäselle erityiskiitos myötätunnosta ja avusta tietoteknisten laitteiden sekä julkaisujen ulkoasujen kanssa.

Opetus- ja kulttuuriministeriötä haluan kiittää tutkimukseni fasilitoimisesta ja tieteellisen rauhan tarjoamisesta. Mieleeni jäi eräs kansainvälinen konferenssi parin vuoden takaa, kun saksalainen tutkijakollegani kommentoi myötätuntoisesti tilannettani kuultuaan tutkimukseni rahoittajan: "et varmaan uskalla julkaista kaikkea, mitä saat tutkimuksessasi selville". Olin hieman ihmeissäni, mutta myös ylpeä todetessani, ettei sensuuri hyödyttäisi niitä pyrkimyksiä, joita rahoittajani fasilitoimisellaan tavoittelee.

Tutkimukseni opetti, että myötämäkien tuuppaaminen ja vastamäkien tamppaaminen on nautinnollisempaa vertaisten kanssa. Olen iloinnut epävirallisista vertaisohjaustuokioista Outi Aarresolan, Misi Szeróvayn ja Elina Hasasen 
kanssa. Lisäksi haluan kiittää Jarmo Mäkistä muutamasta lukuvinkistä ja Mikael Lindfeltiä ideoideni kommentoinnista.

Tutkimukseni ei olisi ollut mahdollista ilman lumilautailijoiden rentoa asennetta akateemisia pyrkimyksiäni kohtaan. Kiitos kaikille vuosien varrella matkaa kanssani taittaneille rentuille. Olette opettaneet paljon ja tarjonneet rutkasti mielenkiintoista tutkittavaa. Erityisesti haluan kiittää Suomen Lumilautaliiton porukkaa myötämielisestä ja avarakatseisesta suhtautumisesta puuhasteluuni. Lisäksi haluan kiittää niitä lumilautamedian edustajia, jotka ovat sitoutuneet yhteistyöhön ja avunantoon tämän projektin aikana. Lupasin lisäksi osoittaa kiitokset Pässille haastateltavan tavoittelemisesta haastista varten.

Perheelle olen kiitollinen niistä hengähdystauoista, joita he ovat tarjonneet urapolkuni lomaan. Tuomoa, Veikkoa ja Tyttiä haluan kiittää erityisesti siitä, että he ovat muistuttaneet maailmassa olevan tärkeämpiäkin asioita, kuin väitöskirjan teko. Toisaalta olen kiitollinen samalle kolmikolle niistä rinneriemuista, joita olemme kokeneet yhdessä tämän neljän vuoden aikana ympäri maailmaa. Olette ehdottomasti parasta laskuseuraa, mutta samalla myös ehkä huonointa afterskiseuraa! Tuomolle kuuluvat lisäksi monet kiitokset niistä hetkistä, kun olen voinut pohtia ääneen löydöksiäni ja saanut testata tulkitojeni kestävyyttä. Valitettavasti tämä hyötysuhde ei ole ollut väitöskirjatöissämme ekvivalentti.

Jyväskylässä, yöllä 1.2.2015, puuterilumen sataessa

Anna-Liisa/Okke 
KUVIOT

KUVIO 1 Tutkimuksen aineiston hyödyntäminen tutkimuksen vaiheissa. ............................................................................ 59

KUVIO 2 Lumilautailun organisoituminen suhteutettuna vauhdin ja maaston muokkaukseen. ................................................... 61

KUVIO 3 Suomalaisten freestyle-lumilautailijoiden uraa raamittavat asenteet, olosuhteet ja resurssit............................................. 77

FIGURE 4 The attitudes, circumstances, and, resources framing the careers of Finnish freestyle snowboarders.............................. 90

\section{TAULUKOT}

TAULUKKO 1 Tutkimusongelmat ja niihin vastaaminen artikkeleissa............ 22 TAULUKKO 2 Urheilun huipputason areenat ja rahoitukselliset perusteet...... 71 


\section{VÄITÖSKIRJAAN SISÄLTYVÄT ARTIKKELIT}

I Ojala, A.-L. 2014. Institutionalisation in professional freestyle snowboarding - Finnish professional riders' perceptions. European Journal for Sport and Society, 11 (2), 103-126.

II Ojala, A.-L. \& Itkonen, H. 2013. Median merkitys nuorisokulttuurisessa liikkumisessa. Nuorisotutkimus, 31 (4), 20-35.

III Ojala, A.-L. \& Thorpe, H. 2015. The role of the coach in action sports: Using a problem-based learning approach. International Sport Coaching Journal, 2 (1), 64-71.

IV Ojala, A.-L. Luovan luokan esiinmarssi huippu-urheiluun: tapaustutkimus suomalaisten ammattilumilautailijoiden ja heidän managereidensa näkemyksistä urheilu-uran resursoinnissa. Lähetetty tieteellisen aikakausilehden arvioitavaksi.

V Ojala, A.-L. \& Itkonen, H. Nautinnonhalu vie voitonjanon: Lumilautailu ja muuttuvat sosialisaatioympäristöt. Kasvatus \& Aika, 8 (4), 7-19. 


\title{
SISÄLLYS
}

\author{
ABSTRACT \\ ESIPUHE \\ KUVIOT JA TAULUKOT \\ SISÄLLYS
}

1 JOHDANTO - SUKELLUS TUTTUUN JA TUNTEMATTOMAAN........... 11

1.1 Tutkimuksen tausta ja konteksti: nuorisokulttuurista

organisoitumista ja omaehtoisuutta....................................................... 11

1.1.1 Uuden lajin pitkä historia lyhyesti ........................................... 12

1.1.2 Nuorisokulttuuria vai vaihtoehtoista elämäntapaa? ................ 14

1.1.3 Lumilautailu suomalaisen organisoidun toiminnan

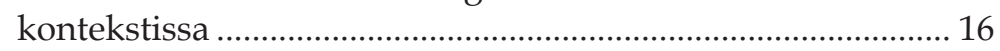

1.1.4 Kaupallisuus ja ammattilumilautailu....................................... 19

1.1.5 Lumilautailun suhde mediaan.................................................. 20

1.2 Tutkimusongelmat ja keskeiset käsitteet................................................ 21

1.2.1 Ongelmia ja kysymyksiä .............................................................. 21

1.2.2 Tutkimuksen käsitteet ja ammattilumilautailun tutkimisen

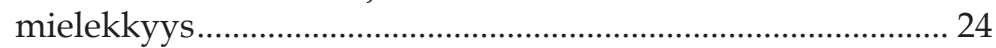

2 TUTKIMUKSEN TEOREETTINEN PERUSTA........................................... 28

2.1 Lumilautailu ja alakulttuurintutkimus.................................................. 28

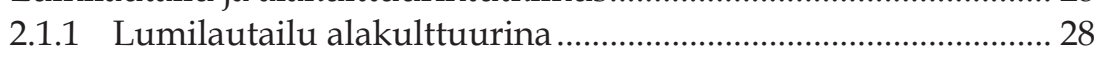

2.1.2 Alakulttuurinen pääoma lumilautailun kentällä ...................... 31

2.2 Uusinstitutionalismi ammattilumilautailukentän hahmottamisvälineenä............................................................................ 33

2.3 Valmennus harrastajien kontrollia kannattavassa lajissa .................... 35

2.3.1 Ongelmakeskeinen oppimisstrategia lumilautailukulttuuriin sopivana valmennusmetodina ................................. 35

2.3.2 Jotain uutta, jotain vanhaa: vertaisvalmennus ja

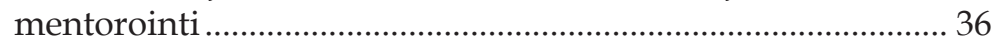

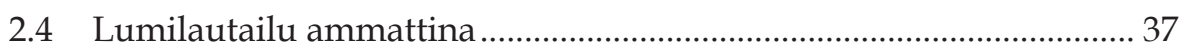

2.4.1 Huippu-urheilun organisoitumisen kolmijako ........................ 38

2.4.2 Ammattilumilautailu luovien toimialojen kontekstissa........... 39

2.5 Lumilautailu sosialisaatioympäristönä ................................................... 40

3 TUTKIMUSPROSESSI JA TUTKIMUKSEN RAKENTUMINEN.................. 44

3.1 Tutkimuksen lähtökohdat ja perusaineiston kertyminen..................... 44

3.2 Ensimmäisen osatutkimuksen toteutus: lumilautailijoiden näkemyksiä itseilmaisusta................................................................... 51

3.3 Toisen osatutkimuksen toteutus: median rooli esiin aiempien tutkimusten kautta 
3.4 Kolmannen osatutkimuksen toteutus: valmentajien rooli lumilautailijoiden kokemana

3.5 Neljännen osatutkimuksen toteutus: lumilautailijan resursointi lautailijoiden ja managerien näkemyksissä ............................................ 56

3.6 Viidennen osatutkimuksen toteutus: lumilautailijoiden urheilu-urien tavoitteet

3.7 Aineisto sekä itsenäisenä kokonaisuutena että keräyskontekstiinsa sidottuna

4.1 Suomalaisten lumilautailijoiden sopeutuminen ammattilumilautailukentän instituutioihin

4.2 Median rooli suomalaisten lumilautailijoiden uralla ............................ 64

4.3 Valmentajien rooli suomalaisten lumilautailijoiden uralla ................. 66

4.4 Suomalaisten lumilautailijoiden uran mahdollistava resursointi ..... 69

4.5 Lumilautailijoiden poikkeavat tavoitteet suhteessa perinteisiin

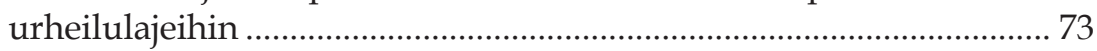

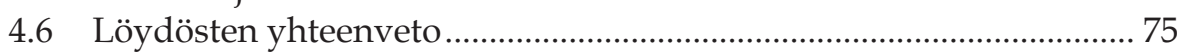

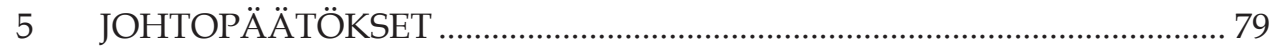

5.1 Tutkimuksen anti lumilautailun ja nuorisokulttuurisen liikkumisen tutkimukselle.....

5.2 Löydösten merkitys liikunnan organisoidun toiminnan ja urheiluvalmennuksen tutkimuksille

5.3 Uusia näkemyksiä urheilun, liikunnan ja liikkumisen käsitteellistämiseen.

5.4 Maailma on nuoren (alakulttuurinen) peili ........................................... 83

5.5 Parhaani tein, katsotaan mihin se riittää .................................................. 85

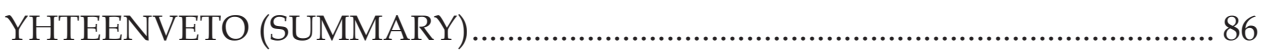

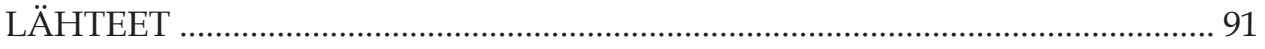

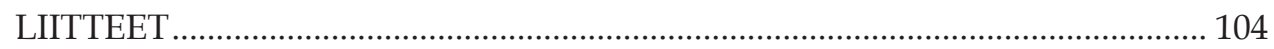




\section{JOHDANTO - SUKELLUS TUTTUUN JA TUNTEMATTOMAAN}

Nuorisokulttuurisen liikkumisen tutkijan on hankala saada otetta tutkimuskohteesta, kun näkökulmia on monia ja tutkimuskohde jatkuvassa muutoksessa. Tämä tutkimus asettaa tarkasteltavakseen nuorisokulttuurisen liikkumisen ja huippu-urheilun rajapinnalla liukuvan suomalaisen ammattilumilautailun, jossa yhdistyy mielenkiintoisella tavalla alakulttuurien muuttuvaisuus ja ilmaisuvoima, viihde- ja mediabisneksen kaupalliset mahdollisuudet sekä huippuurheilukentän pyrkimys tuloksellisuuteen. Esittelen ensin tutkimuksen taustan, tutkimusongelmat ja -käsitteet, minkä jälkeen siirryn teoreettisen viitekehyksen kautta tutkimusprosessin kuvaamiseen ja löydöksiin. Lopuksi esitän tutkimuksen johtopäätökset ja jatkosuositukset.

\subsection{Tutkimuksen tausta ja konteksti: nuorisokulttuurista organisoitumista ja omaehtoisuutta}

Ammattilaisuuteen kiinnittyessään suomalaiset lumilautailijat paikantuvat kenttään, jossa nuorisokulttuurinen liikkuminen yhdistyy urheiluun kaupallisuuteen ja mediaan. Urheilun resurssit tällä viihdebisnekseksi muodostuvalla kentällä syntyvät sen kyvyistä kantaa merkityksiä (Wernick 1991, 109). Merkitykset, joita media ja hyödyketeollisuus pyrkivät myymään kuluttajille, mahdollistavat urheilun kaupallistamisen ja liikuntasosiologi John Hornen $(2006,14)$ mukaan myös globalisoitumisen: niin urheilua organisoivien yritysten kuin sponsorienkin tavoitteena on laajentaa markkinoitaan uusien kuluttajien saavuttamiseksi, mikä tarkoittaa hakeutumista kansainvälisille kentille. Seuraavissa tutkimuksen taustaa ja kontekstia käsittelevissä alaluvuissa ankkuroin tarkasteluni urheilun, kaupallisuuden ja median kolmijakoon lumilautailun kontekstissa. Ensimmäiset kolme alalukua käsittelevät lumilautailua liikkumismuotona historian, nuorisokulttuurien ja organisoidun toiminnan suunnista. Seuraavat kaksi alalukua avaavat lyhyesti ammattilumilautailun suhdetta kaupalli- 
suuteen ja mediaan ennen tutkimusongelmien ja -kysymysten tarkempaa esittelyä sekä käsitteiden määrittelyä.

\subsubsection{Uuden lajin pitkä historia lyhyesti}

Lumilautailu on urheilun historiassa suhteellisen uusi laji. Vaikka poikittain erilaisten objektien päällä liukumista on harjoitettu leikinomaisesti lumella vuosisatoja, katsotaan nykylumilautailun syntyneen vasta 1960-luvulla surffauksen ja pulkkailun perinteistä (Howe 1998, 5-6). 1960-luvun puolivälissä michiganilainen insinööri Sherman Poppen kiinnitti kaksi suksea yhteen lasten leikkejä varten ja nimitti aikaansaannostaan Snurfferiksi. Snurfferista ja sen suosiosta innostunut Jake Burton Carpenter kehitti lelusta 1970-luvulla massatuotantoon ja urheilemiseen sopivamman version, mikä johti liikkumismuodon suosion kasvaessa tuottoisan tuotemerkin kehittymiseen (Thorpe 2011, 21-22; Howe 1998, 9-11).

Susanna Howe $(1998,28-35)$ kuvailee kirjoittamassaan lumilautailun sosiaalihistoriassa, kuinka lumilautojen kehittelystä innostuneet toimijat PohjoisAmerikan eri puolilla saivat lähtökohdikseen omien vuoristojensa erilaiset olosuhteet ja ympäristöjensä kulttuurit, mikä vaikutti jo alkuvuosina erilaisten lumilautailugenrejen syntymiseen. Merkittävimmät perinteet tämän tutkimuksen kannalta vahvistuivat 1980-luvulla, kun lumilautoja saattoi saada nyrkkipajojen sijasta erikoiskaupoista ja yleisöistä alettiin kilpailla. Jake Burton Carpenterin tukema lumilautailun kehitys kohti hyväksyttyä urheilua sekä kalifornialaisen Tom Simsin rullalautailuperinteestä vaikutteet ottanut alakulttuurisuus näkyivät heidän ylläpitämissään tiimeissä ja järjestämissään kilpailuissa (Howe 1998, 43-52).

Lumilautailun alakulttuurimaisuuden kehittymisen kannalta oli merkittävää, ettei suurin osa hiihtokeskuksista päästänyt lumilautailijoita rinteisiinsä ennen 1980-luvun puoliväliä ja loppua. Lumilautailun ympärille muodostui vastakulttuurisuuden leima, jopa monien lumilautailijoiden sovittelevista pyrkimyksistä huolimatta (Howe 1998, 39-41). Hiihtokeskusten ulkopuolella harrastaneet lumilautailijat loivat omalle lajilleen ominaisen tavan liikkua, mikä poikkesi muista hiihtolajeista. Lopulta lumilautailun omintakeinen kehitys kaipasi apua hiihtokeskuksilta: Kasvanut vauhti, korkeammalle suuntautuneet hypyt sekä varsinkin Kalifornian Lake Tahoella luonnon muodostamissa lumikouruissa laskeminen aiheuttivat vaatimuksen yhä paremmista olosuhteista. Kun hiihtokeskusyrittäjät huomasivat kasvavan lumilautailijajoukon potentiaalisina asiakkaina, pääsivät lumilautailijat muokkaamaan elämäntapaansa urheilun suuntaan hiihtokeskusten rinteille (Thorpe 2007). Temppuiluun keskittyvä freestyle-lumilautailu on aina ollut nuoren lumilautailuyleisön mieleen (Thorpe 2010), eikä hiihtokeskusyrittäjillä ollut varaa olla ottamatta huomioon lisääntyvää nuorten harrastajien joukkoa.

Lumilautailun omaleimainen liikkuminen yhdistettynä surffauksesta ja skeittauksesta omaksuttuihin vaikutteisiin loi varhaisista lumilautailutapahtumista kulttuurisia juhlia, joissa näytettiin taitoja, haettiin vaikutteita ja käyttäydyttiin hyvin epäurheilijamaisesti hegemoniseen urheilukulttuuriin nähden 
(Humphreys 1997; Howe 1998, 43-44; Thorpe 2012b). Vaikka lumilautailu on tulkittu alkuvuosinaan suhteellisen tasa-arvoisena harrastuksena naisille ja miehille, toivat myöhemmät vuodet mukanaan maskuliinisen hegemonisuuden (Thorpe 2006). Vakiintunut lumilautailukulttuuri päihteitä railakkaasti käyttävine harrastajineen ja uhkarohkeine ruumiillisine käytäntöineen on tulkittu nuorten miesten ruumiinkäytäntöjen ja ideologioiden luonnollistettuna leikkikenttänä, jossa pärjätäkseen naisten on yhtä aikaa miellytettävä miesten silmää naisellisuudellaan ja toimittava miehisillä tavoilla (Anderson 1999; Thorpe 2005; 2006; 2008; 2009b; 2011, 170-171; Sisjord 2009; 2013; Lindström 2012).

Lumilautailuun varhain kehittyneistä erilaisista genreistä huolimatta lumilautailun sisimmässä asui alkuvuosista asti kollektiivinen ajatus siitä, että lumilautailu poikkesi perinteisestä laskettelukulttuurista (Thorpe 2011, 22-23). Tämä näkemys dokumentoitui verrattain uudesta lajista kiinnostuneisiin tutkimuksiin, jotka varsinkin 1990-luvulla ja 2000-luvun alussa painottivat lumilautailun alakulttuurisuutta perinteiseen urheilukulttuuriin nähden (ks. esim. Humphreys 1996; 1997; 2003).

Lumilautailun suosio synnytti myös tarpeen lajia kehittäville ja kilpailuja järjestäville organisaatioille. Ensimmäiset lumisurffauksen mestaruuskisat järjestettiin Yhdysvaltojen Vermontissa vuonna 1982 ja viisi vuotta sen jälkeen perustettiin Pohjois-Amerikkaan ja Eurooppaan omat lumilautailuorganisaatiot. Vuonna 1991 aiemmat liitot yhdistettiin kansainväliseksi lumilautailujärjestö ISF:ksi (International Snowboarding Federation), joka toimi kattojärjestönä myös kansallisille liitoille. (Humphreys 1996.)

Lumilautailun kasvanut suosio 1990-luvun alussa herätti Kansainvälisen Olympiakomitean kiinnostuksen lajia kohtaan. Lumilautailun, purjelautailun ja BMX-pyöräilyn olympiasuhteita kulttuuripoliittisesti tutkineiden Holly Thorpen ja Belinda Wheatonin (2011) mukaan tämä kiinnostus osui juuri siihen ajankohtaan, kun olympialaisten tarjonta ei näyttänyt liikuttavan nuorisoa. Samaan aikaan heräsi Kansainvälisen Hiihtoliiton (FIS) kiinnostus suosiota keränneen lumilajin edustamisesta. Organisaatioiden valtataistelu vaikutti myös kansallisiin organisaatioihin, joiden piti päättää, mille taholle he haluavat kumartaa ja mille samalla kääntää selkänsä (Popovic 2006). Tästä ajanjaksosta seurannut kehityskulku muutti perustavanlaatuisesti niin lumilautailun kuin lumilautailututkimuksen kehityssuuntaa.

Kansainvälinen hiihtoliitto tarjoutui edustamaan lumilautailua olympialaissa lumilautailijoiden äänekkäästä vastustuksesta huolimatta (Popovic 2006; Thorpe \& Wheaton 2011). Lumilautailusta tuli olympialaji Naganossa 1998. Yhtäkkiä lumilautailu oli vaihtoehtolajin sijasta huippu-urheilua, mikä näkyy tutkimuksissa (Thorpe 2007; Thorpe 2011, 27-28; Thorpe \& Wheaton 2011) kertomuksina siitä, kuinka lumilautailusta tuli valtavirtaa. Samat tutkimukset esittivät olympialaisten lisäksi vuonna 1995 perustetut mediayhtiö ESPN:n X Games -kilpailut ja yleisen kaupallistumisen merkittävinä tekijöinä kehityskaaressa, jossa lumilautailusta tulee tavallista urheilun showbisnestä.

Lumilautailukulttuurin sisälle on kuitenkin mahtunut enemmän kuin yksi totuus kerrallaan. Valtavirtaisuuden kyljessä on sinnitellyt monia tapoja harjoit- 
taa lajia jopa huipputasolla valtavirrasta poikkeavasti. Urheiluorganisaatioiden kontekstissa vaihtoehtoisuus on tarkoittanut Ticket to Ride -organisaation (TTR), eli uuden lumilautailijavetoisen kansainvälisen kattojärjestön perustamista vuonna 2002. TTR:n ylläpitämä sertifiointijärjestelmä, joka muuttui kaudella 2012-2013 World Snowboard Touriksi, on kerännyt tärkeimmät lumilautailukilpailut yhdeksi kiertueeksi siten, ettei lumilautailijoiden ole tarvinnut kilpailla hiihtoliiton kilpailuissa kuin olympiavuonna (World Snowboard Tour s.a.). Toisaalta myös vahva erikoismedia on tarjonnut lumilautailijoille mahdollisuuksia näyttää taitojaan kilpailuista poikkeavilla areenoilla. Samalla lumilautailukilpailuiden sertifiointi ja televisiointi sekä lumilautailukuvausten hyödynnettävyys markkinoinnissa ovat taanneet joillekin lumilautailijoille suhteellisen hyvät tienestit, joiden eteen lumilautailijoiden on toisaalta pitänyt tehdä ideologisia myönnytyksiä. Tämä mielenkiintoinen yhdistelmä vaihtoehtoisuutta ja valtavirtaisuutta on tarjonnut väitöskirjatyölleni sen kontekstin, johon olen tutkimukseni ankkuroinut. Vaihtoehtoisuuden ja valtavirtaisuuden yhdistyminen urheilun ammattitasolla on myös aiheena ajankohtainen ja vähän tutkittu, mikä tekee tutkimuksestani ajankohtaisen.

\subsubsection{Nuorisokulttuuria vai vaihtoehtoista elämäntapaa?}

Lumilautailu kuuluu luokitteluissa ruumiillisuuden muotoihin, joista puhutaan Suomessa nuorisokulttuurisena liikkumisena (Hasanen 2001; Hänninen 2012; Itkonen 2012). Englanninkielisessä tutkimuskirjallisuudessa nuorisoon viittaavaa sosiaalista kategoriaa ei ole haluttu sisällyttää lumilautailun kaltaisia lajeja kuvaavaan termistöön. Esimerkiksi liikuntasosiologi Belinda Wheatonin $(2013,29)$ mukaan kyseisistä liikuntamuodoista on innostunut iältään hyvinkin vaihteleva harrastajajoukko. En kuitenkaan näe nuorisokulttuurista liikkumista tämän tutkimuksen kannalta harhaanjohtavana käsitteenä. Vaikka joidenkin musiikkigenrejen yleisöjen tavoin freestyle-lumilautailun harrastajajoukko voi olla iältään kirjava, osuu freestyle-lumilautailun kulttuuria aktiivisesti kehittävien ikähaarukka nuoruuteen ja varhaiseen aikuisuuteen, kuten Holly Thorpen (2010) lumilautailevien miesten maskuliinisuuden kehittymistä tarkasteleva tutkimus antaa olettaa.

Nuorisotutkija Andy Bennett (2007) näkeekin tärkeänä erottaa fyysisen ja kulttuurisen nuoruuden. Puhuttaessa freestyle-lumilautailusta nuorisokulttuurina viitataan siis kulttuuriin, jonka merkitykset ovat pääosin nuorista lähtöisin, eivätkä aikuisten urheilukulttuurin imitointia, kuten perinteisemmissä urheilulajeissa voi olla (ks. Itkonen 2012). Vanhempi harrastaja saattaa jopa kokea itsensä lumilautailemalla biologista ikäänsä nuoremmaksi (ks. Bennett 2007). Vaikka näin ei kaikkien harrastajien kohdalla olisikaan, olen selvyyden vuoksi käyttänyt suomalaisissa tutkimusosioissani nuorisokulttuurista liikkumista lumilautailun kaltaisten lajien yläkäsitteenä.

Englanninkielisessä tutkimuskirjallisuudessa lumilautailu kategorisoidaan nuoruuden sijasta elämäntavan, vaihtoehtoisuuden, äärikokemusten tai toiminnan käsitteiden avulla. Englanninkielisen käsitteistön suurimpana erona suomalaiseen voidaan pitää sitä, että englanninkielisten yläkäsitteiden alle si- 
sällytetään myös esimerkiksi vuorikiipeily, laskuvarjohyppy sekä isojen vuorten lumilautailu. Nämä liikkumismuodot vaativat harrastajiltaan niin paljon kokemusta tekniikasta ja luonnonolosuhteista, ettei nuorilla olisi mahdollista olla näiden lajien keskiössä. Suomessa kyseisille lajimuodoille ei ole vakiintunutta yläkäsitettä, jollei haluta käyttää englanninkielisten käsitteiden käännöksiä.

Wheaton (2004, 4-5) päätyy käyttämään elämäntapaurheilun käsitettä kuvatessaan lumilautailun, skeittauksen, surffauksen, purjelautailun tai kiipeilyn tapaisia liikkumismuotoja ennen muuta siitä syystä, että hänen tutkimustensa osanottajat ovat painottaneet kokevansa kyseiset lajit elämäntapoina. Nämä elämäntavat, jotka eri lajien omista erityispiirteistä ja historioista huolimatta kannustavat hauskuuteen, harrastajalähtöisyyteen, vapauteen, hetkeen tarttumiseen, luovuuteen, esteettisyyteen ja itsensä ilmaisemiseen, vaikuttavat harrastajien identiteetteihin siten, että voidaan puhua lajeista saman yläkategorian alla (Wheaton 2004, 9-12).

Extreme-urheilusta puhutaan yhä varsinkin psykologian (esim. Hetland \& Vitterso 2012; Brymer \& Schweitzer 2013; Seiler 2014) ja markkinoinnin tutkimuksissa (esim. Walker 2002; Liberman 2003; Olson 2012) kuvattaessa samaa lajikokonaisuutta, jota Wheaton $(2004,2013)$ nimittää elämäntapaurheiluksi. Monet tutkijat jättävät tietoisesti äärikokemuksiin viittaavan extreme-termin markkinoijille ja käyttävät tutkimuksissaan muita käsitteitä. Holly Thorpe (2009a) kuitenkin muistuttaa, että vaikka harrastamisen riskit lumilautailun kaltaisissa lajeissa riippuvat lopulta yksilöiden halusta ottaa riskejä sen sijaan, että riskien otto olisi lajeihin sisään kirjattua, tuovat muuttuvat harrastusolosuhteet perinteisistä urheilulajeista poikkeavissa ympäristöissä harrastamiseen toisinaan äärikokemuksia.

Lumilautailun ja muiden samankaltaisten lajien luokittelua vaihtoehtolajeiksi ovat vauhdittaneet tutkimukset, joissa todetaan lajien harrastajien haastavan ja kyseenalaistavan perinteisen liikuntakulttuurin sääntöjä ja tapoja tehdäkseen liikkumisesta itsensä näköistä (esim. Beal 2005; Thorpe 2009c; Turner 2013). Kyseisiä liikkumismuotoja luokittelevista termeistä käytetyin lienee nykyään kuitenkin action sports, joka suhtautuu neutraalisti elämäntapaan ja ikään liittyviin oletuksiin. Niissä harvoissa tutkimuksissa, joissa sivutaan action sports käsitteen etymologiaa, todetaan lajien perustuvan 1960-70-lukujen vapaa-ajan trendeistä nousseelle hedonistiselle toiminnallisuudelle ja ilmaisuvapaudelle (ks. esim. Bennett, Henson \& Zhang 2002; Thorpe \& Wheaton 2011). Olen luokitellut lumilautailun tutkimukseni englanninkielisissä osatutkimuksissa action sportsiksi käsitteen yleisyydestä johtuen.

Nuorisokulttuuristen lajien kyvyn puhutella nykyajan nuorisoa sekä vanhempaa yleisöä on nähty johtuvan yksinkertaisesti siitä, että kyseiset liikkumismuodot sopivat hyvin nykyajalle ominaisiin kulttuurisiin käytäntöihin. Nuorisokulttuuristen lajien on nähty tarjoavan keinoja ajalle ominaiseen elämän- ja riskienhallinnan pyrkimyksiin, muuttuviin identiteetteihin ja refleksiivisyyteen (Wheaton 2013, 4-5). 


\subsubsection{Lumilautailu suomalaisen organisoidun toiminnan kontekstissa}

Kolmannen sektorin toiminnalla on Suomessa pitkät perinteet. Tuntuisi kummalliselta tutkia suomalaisten lumilautailijoiden kiinnittymistä ammattilaisuuteen ilman lumilautailun peilaamista edes pintapuolisesti suomalaisen organisoidun järjestöliikunnan ja urheilun kenttään. Siksi selvitin Suomen Lumilautaliiton ja seurojen toimintaa puhelimitse vuonna 2011 liiton silloiselta toiminnanjohtajalta Mats Lindforsilta sekä seuratoiminnasta vastanneelta Paulus Ähtävältä. Vaikka tämä tarkastelu jää todelliseksi pintaraapaisuksi - osin siksi, ettei lumilautailuseuroja ole tutkittu edes kansainvälisesti - näen tarkastelun tärkeänä: organisoidun toiminnan konteksti yhdistää lumilautailun osaksi niitä liikkumiskäytäntöjä ja tutkimusperinteitä, jotka ovat suomalaisissa liikkumiskulttuureissa ja niiden tutkimuksissa tyypillisiä (ks. Itkonen 1996; Siisiäinen 2007). Avaamalla lyhyesti alaluvun lopussa lumilautailun valmennuskulttuuria tuon lumilautailun osaksi huippu-urheilun kenttää, jossa valmentautuminen on urheilijan uralla liki itsestäänselvyys.

Suomessa on tyypillistä, että suosiotaan kasvattavan lajin ympärille perustetaan urheiluseuroja. Lumilautailu ei tehnyt tässä mielessä poikkeusta. Vuonna 1988 Suomeen perustettiin yksi maailman ensimmäisistä lumilautailuliitoista (Areng \& Willners 1995, 14); muutama vuosi myöhemmin kuin lumilautailua esiteltiin ensikertoja suomalaisessa mediassa (Hänninen 2007). Vuonna 2014 lumilautaseuroja on Suomen Lumilautaliiton (s.a.) internetsivujen mukaan 36, mutta osa niistä on oman kokemukseni ja Mats Lindforsin (henkilökohtainen tiedonanto 15.11.2011) kolmen vuoden takaisen arvion perusteella niin kutsuttuja pöytälaatikkoseuroja, joiden aktiivinen toiminta on hyvin vähäistä tai olematonta.

Paikkakunnilla, joilla lumilautailun seuratoiminta on vahvaa, organisoidaan myös kilpailuja. Näillä paikkakunnilla aktiivisia kilpalaskijoitakin on ymmärrettävästi enemmän kuin seuratoiminnaltaan vähäisemmillä alueilla. Nämä seurat toimivat seuratoimintavastaava Paulus Ähtävän (henkilökohtainen tiedonanto 16.11.2011) mukaan pääsääntöisesti suurempien kaupunkien hiihtokeskuksissa. Seurojen perustamiseen ja toiminnan aktivointiin liitto on kannustanut muun muassa Parkkikoulu-tempauksin, joilla valmennusta herätellään hiihtokeskuksissa, mutta toiminnan tulee olla jäsenseurojen järjestämää.

Lumilautaseurojen toiminta on noudattanut hyvin samankaltaisia malleja kuin perinteisten kilpaurheilulajien. Vaikka lumilautailussa kilpailemisen rinnalla harrastajat esittelevät taitojaan myös audiovisuaalisten laitteiden ja median välityksellä, ei kuvaustoiminnan kytkeminen seuratoimintaan ole ollut yleistä. Paulus Ähtävä mainitsi puhelinkeskustelussa marraskuussa 2011 oman yrityksensä järjestävän kaudella 2011-2012 harrastajille kaksi kuvausleiriä. Ähtävän mukaan oli luontevampaa järjestää kuvausleirit oman yrityksen kuin seuratoiminnan tai liiton toimesta: 
P. Ä.: Seurat pyörii valmennuksen ympärillä tai niin se usein ainaki koetaan. Kuvaamista ei koeta seuratoiminnan alle, kun kuvaamista harjoittaa lokaalit porukat eikä seuroilla oo ollut tarjottavaa videoporukoille. Seuroissa tähdätään kisoihin ja niitä valmennetaan.

A-L. O.: Miksei seurat tavoita videoporukoita?

P. Ä.: Lumilautailijoilla on seuratoiminnasta se ajatus, et eiks se oo vähän tyhmää se seurahomma. Se ajatus oli Messilänkin suhteen ku alettiin perustaa sitä [uutta seuraa]. . . Jos seuroilta tulis enemmän infoa siihen suuntaan, et viedään liittoa kisoista pois, mut ku seuroista tulee huonosti mitään, miten pitäis olla ja liiton kokouksissaki on vähemmän näitä nuoria.

(Paulus Ähtävä, henkilökohtainen tiedonanto 16.11.2011)

Ähtävän kommentin perusteella voisi päätellä, että valmennusta kaipaavat ja kilpailuihin tähtäävät nuoret saattavat olla seurojen ja liiton toiminnassa mukana, kun taas kuvauspuolta harrastavat ja lumilautailun sosiaalista puolta painottavat nuoret organisoivat toimintaansa kaveriporukoiden toimin. Suomen Lumilautaliitto joutuu toimintatavoissaan huomioimaan nämä lajin harrastajille ominaiset identiteetit, joihin lajiliittokin on harrastajia edustaessaan sidottu (Steen-Johnsen 2008). Suomen Lumilautaliitto onkin pyrkinyt pois pelkästä seuratoimintaleimasta tekemällä yhteistyötä esimerkiksi yksityisten kilpailujärjestäjien kanssa, jolloin liiton kilpailukiertueet on järjestetty harrastajien arvostamien yksityisten toimijoiden organisoimina.

Tarkasteltaessa Suomen Lumilautaliiton rahoituksen kehitystä ei liene epäselvää, että kilpailutoiminnan ja huippu-urheilun kehittäminen ja ylläpito on liitolle tärkeää. Tilikaudella 2013 reilusti yli kolmasosa, jollei jopa puolet, Suomen Lumilautaliiton toiminnan rahoituksesta saatiin Olympiakomitean valmennusmäärärahoina, huippu-urheilun vuoksi maksettavina sponsorituloina tai siihen ohjautuvana opetus- ja kulttuuriministeriön toiminta-avustuksena (Suomen Lumilautaliitto 2013; Mika Andersson, henkilökohtainen tiedonanto 5.11.2014). Legitimoidakseen Olympiakomiten ja sponsorien tulot Suomen Lumilautaliiton on kyettävä osoittamaan mesenaattien toivomia tuloksia huippuurheilun saralla. Harrastajien kilpailutoiminnalla tai leiritoiminnalla liitto ei kuitenkaan yritä kartuttaa tuloja esimerkiksi huippu-urheilijoiden käyttöön. Kynnys kilpailuihin osallistumiseen pyritään pitämään matalana siten, että lisenssit ovat pakollisia vain kansainvälisen hiihtoliiton alaisissa kilpailuissa ja muutoin lajilisenssi toimii kilpailumaksuna kaikkiin liiton järjestämiin kilpailuihin.

Vaikka kilpailumenestys on Suomen Lumilautaliitolle tärkeää, ei liiton valta lumilautailussa ole edes kilpailuissa samankaltainen kuin perinteisessä kilpaurheilussa. Arvostetuimpia kansainvälisiä kilpailuja järjestävät yksityiset 
organisaatiot ja mediayhtiöt, joiden kilpailijavalintoihin Suomen Lumilautaliitolla ei ole yleensä mahdollisuutta vaikuttaa. Myöskään yhteiskunnan resursseja ei ole tarvittu lumilautailun edistämiseen samalla tavalla kuin liikuntasosiologi Hannu Itkonen (1996, 224) mainitsee tapahtuneen kilpailullisvalmennuksellisesta kaudesta (1960-luvun lopulta) eteenpäin suomalaisessa urheilussa. Harjoitteleminen lumilautailussa on ollut riippuvaista kaupallisin perustein toimivien hiihtokeskusten fasiliteeteista, eikä kunnilla ja seuroilla ole ollut ratkaisevaa merkitystä harrastepaikkojen takaamisessa. Luonnollisissa ympäristöissä harjoitettavat lumilautailun genret ovat olleet vielä vähemmän riippuvaisia ulkopuolisista toimijoista.

Liikuntatieteilijä Kari Steen-Johnsenin (2008) Norjan lumilautaliiton toimintamalleja tarkastelleen tutkimuksen mukaan nuorisokulttuuristen lajien harrastajien vahva pyrkimys individualismiin, leikkimielisyyteen ja epäautoritäärisiin toimintamalleihin aiheuttaa tilanteen, jossa liiton on hankala miellyttää harrastajia ja tehdä samalla yhteistyötä perinteisten urheilujärjestöjen, kuten kansallisen olympiakomitean kanssa. Yhtä lailla voidaan huomata, että jos valtavirtamedioissa esitettävät lumilautailudiskurssit ja kilpailutapahtumat, kuten olympialaiset ja maailmanmestaruuskilpailut, ovat Suomen Lumilautaliitolle onnistuneen toiminnan rahoittajina ja osoittajina tärkeitä, ovat ne lumilautailun alakulttuurin markkinointikanavina ja elämäntavan välittäjinä vähemmän merkityksellisiä (ks. Thorpe 2011, 77-81).

Lumilautailu on käynyt läpi mittavia muutoksia viimeisten vuosikymmenten aikana, eikä ole yllättävää, etteivät kaikki lumilautailijat kaipaa vapautta ja omaehtoisuutta harjoittaessaan lajiaan. Jos yhteistyö valmentajien kanssa oli ollut lumilautailun alkuvuosikymmeninä ammattilaislumilautailijalle häpeällistä, voi se olla nykyisille olympiaurheilijoille normaali menestyksen tavoittelun strategia.

Kansallisten liittojen ja olympiakomiteoiden investoidessa lumilautailijoiden menestykseen myös ammattivalmentajien määrä lisääntyy. Nämä valmentajat saavat kunniaa urheilun emokulttuurissa lumilautailijoiden pärjätessä. Esimerkiksi amerikkalainen lumikouruvalmentaja Rick Bower valittiin vuoden 2011 olympiavalmentajaksi. Hän oli jo kolmas kyseisellä tittelillä palkittu amerikkalainen lumilautailuvalmentaja kymmenen vuoden sisällä (USSA 2012). Myös Suomen Valmentajat ry. valitsi Suomen Lumilautaliiton päävalmentajan, Pekka Koskelan, vuoden 2013 valmentajaksi suomalaislumilautailijoiden hyvän kilpailumenestyksen vuoksi (Suomen Valmentajat ry 2014). Nämä nimitykset asettavat valmentajat sellaiseen valoon, jossa heidän nähdään omaavan urheilijan - tässä tapauksessa lumilautailijan - suorituksia parantavaa tietoa (ks. Potrac \& Cassidy 2006; Cassidy, Jones \& Potrac 2009). Yhtä lailla nämä nimitykset kertovat valmentajien ammattimaistumisesta, mikä merkitsee myös valmentajan aseman kyseenalaistamattomuutta urheilijan uralla (Taylor \& Garratt 2013). 


\subsubsection{Kaupallisuus ja ammattilumilautailu}

Nuorisokulttuuriset lajit kykenevät välittämään uusliberalistisessa kapitalismissa hyvin teollisuudelle ja medialle tarpeellisia merkityksiä (Bennett, Henson \& Zhang 2002; 2003; 2004). Vaikka esimerkiksi nuorisokulttuurisiin lajeihin erikoistunut X Games -kilpailutapahtuma oli nimensäkin mukaisesti suunnattu 1970-80-luvuilla syntyneelle X-sukupolvelle (Crawford 2007), ovat nuorisokulttuurisen urheilutapahtumat liikuttaneet myös 1980-1990-luvuilla syntyneen Ysukupolven edustajia perinteisiä urheilutapahtumia paremmin (Bennett, Henson \& Zhang 2003; Thorpe \& Wheaton 2011). Lajien jännittävyys ja vauhti ovat sopineet varsinkin nuorten miesyleisöjen tavoittamiseen, mikä kiinnostaa hyödyketeollisuutta ja mediaa (Wheaton 2013, 3).

Ammattilumilautailijoiden kaupallinen rooli nopeasti kehittyvässä ja vahvasti medioituneessa alakulttuurissa on ollut alusta asti merkittävä. Lumilautavalmistajilla on ollut varhaisvaiheista asti omat tiiminsä (Howe 1998, 47) ja tuotteita on myyty ennen muuta ammattilumilautailijoiden imagoilla (Humphreys 1997). Imagoperusteisuuden vuoksi teollisuus ja media ovat olleet kiinnostuneita lumilautailijoiden taitojen lisäksi lumilautailijoiden persoonallisuuksien ja asenteiden sopivuudesta tarkoituksiinsa (Thorpe 2011, 57). Tavoiteltaessa nuorten miesten mielenkiintoa urheilijan imagon ei ole tarvinnut edustaa perinteisten lajien puhtoista ideaalityyppiä. Särmikkäät persoonat massasta erottuvine tyyleineen ja toimintamalleineen ovat vedonneet valtavirtayleisöönkin, kuten Salt Lake Cityn olympialaisista ja lumilautailija Heikki Sorsan irokeesikampauksesta muistamme.

Lumilautailun kiinnostavuudesta mediaurheiluna kertovat Holly Thorpen $(2011,2)$ tutkimukseensa aikakausilehdistä keräämät tiedot, joiden mukaan lumilautailija Shaun White oli Vancouverin olympialaisten suosituin urheilija ja lumikourun finaaleja seurasi pelkästään yhdysvalloissa yli 30 miljoonaa TVkatsojaa. Tässä valossa ei ole lainkaan kummallista, että lumilautailu kiinnostaa teollisuutta ja mediaa ja laji kaupallistuu. Jos aiemmat tutkimukset näkivät nuorisokulttuuristen lajien kaupallistumisen tapahtuvan teollisuuden ja median ohjauksella, hahmottavat uudemmat tutkimukset nuorisokulttuuristen lajien ja kaupallisuuden kietoutuvan monimutkaisiksi kokonaisuuksiksi, joissa myös nuorisokulttuuristen lajien osanottajat pyrkivät aktiivisesti hyötymään (Edwards \& Corte 2010; Wheaton 2013, 37).

Yhtä lailla lumilautailun kaupallistuminen mahdollistaa työpaikkoja innokkaille lumilautailijoille myös ammattilaisina. Thorpe (2011,57-59) kuitenkin muistuttaa, että vaikka ammattilaisuus voi tuntua unelmatyöpaikalta, tuo kaupallistaminen mukanaan vieraantumisen omasta tekemisestä, kun suoritukset hyödykkeistetään. Tunne vieraantumisesta voi olla erityisen vahva lajissa, jossa elää illuusio vapaudesta ja luovuudesta. Tämä kaupallisuuden, lumilautailijuuden ja median kietoutuneisuus tarjoaa tutkimukselleni mielenkiintoisen kohteen ja asettaa lumilautailun siihen kontekstiin, jossa yhden lajin tutkiminen voi vastata laajempiin ajankohtaisiin yhteiskunnallisiin ja liikuntatieteellisiin kysymyksiin. 


\subsubsection{Lumilautailun suhde mediaan}

Median suhde urheiluun on niin läheinen, että urheilusosiologi John Horne (2006, 40-41) esittää median vaikuttaneen sen muodostumiseen, mitä nykyään kutsutaan moderniksi huippu-urheiluksi. Massamedian kehittyminen ja yhteistyö urheilun kanssa on tehnyt urheilusta populaarikulttuuria muun viihdeteollisuuden rinnalle. Populaarikulttuurin osana urheilun ja urheilijoiden riippuvuus julkisuudesta kasvaa, jolloin urheilulajien ja urheilijoiden tulee sopia median narratiiveihin säilyäkseen pinnalla (Ruddock 2013, 159).

Alakulttuurin sisällä toimivat mediat ja paikallismediat vaikuttavat massamedian rinnalla alakulttuuristen muodostelmien syntymiseen ja ylläpitoon (Thornton 1996). Vakaa suhde erikoismediaan on lisännyt lumilautailijoiden mahdollisuuksia perinteisistä urheilulajeista poikkeaviin ilmaisumuotoihin. Lumilautailuun syntyi erikoismedia lehtineen ja videoineen jo 1980-luvun loppupuolella surffaus- ja skeittauskulttuureiden vaikutteiden sekä kenttien yhteisten toimijoiden vuoksi (Howe 1998, 103-106; Hufman 2008). Howen (1998, 104) journalistisen sosiaalihistorian mukaan erikoismedian sekä kuvaajien merkitys oli huomattavan suuri lumilautailuissa sen vuoksi, että lumilautailijat olivat omistautunutta yleisöä. Lehtiä luettiin kuin kuvakirjaa ja videoilta opiskeltiin viimeisimmät kehityssuunnat. Näin ollen lumilautailun kyky välittää merkityksiä on kietoutunut tiukasti erikoismediaan.

Valtavirtamedian rooli ei muodostunut lumilautailussa yhtä tärkeäksi kuin erikoismedian, sillä valtavirtamedian toimittajat olivat suhteellisen tietämättömiä lajista ja vahvistivat Thorpen $(2011,77)$ mukaan kulttuurisia stereotypioita uusien suuntauksien levittämisen sijaan. Tässä ilmapiirissä myös erikoismedian rooli lumilautailuteollisuuden imagonluojana pääsi kehittymään vahvaksi (Howe 1998). Tämä on kiinnostava lähestymiskulma omaa tutkimustani ajatellen. Jos urheilun, valtavirtamedian ja markkinoiden suhde on nähty urheilututkimuksissa toisistaan riippuvaisena (ks. esim. Itkonen 1996, 230; Horne 2006, 40-43; Boyle \& Haynes 2009, 17-18), tulee lumilautailijoiden kiinnittymistä ammattilaisuuteen tarkastelevassa tutkimuksessani huomioida myös erikoismedian poikkeuksellisen merkittävä rooli ammattiurheilun ylläpidossa ja eri genrejen mahdollistamisessa.

Vaikka median muodot ovat lisääntyneet internetin kehittyessä, ei lumilautailijoiden innostus mediayhteistyölle sekä -kulutukselle näytä muuttuneen. Thorpe (2011, 77-81) osoittaa valtavirtamedian tuottavan yhä kaupallista kuvaa lumilautailusta suurelle yleisölle menestyksekkäästi ja lumilautailijoiden etsivän tietoa lumilautailun kehityssuunnista erikoislehdistä ja -videoilta. Verkkomedian roolia lumilautailussa ei Thorpenkaan (emt., 81-83) tutkimus kykene tyhjentävästi selittämään, vaan tyytyy toteamaan lumilautailijoiden käyttävän sosiaalista mediaa yhä enemmän lumilautailun ruumiillisia käytänteitä koskevassa kommunikoinnissaan. Näin ollen kun aiemmat tutkimukset lumilautailun organisoitumisesta kilpailuja ja urheilujärjestöjä koskien tarjosivat tutkimukselleni yhtä aikaa valtavirtaisuutta ja vaihtoehtoisuutta alleviivaavan pohjan, eivät mediaa koskevat tutkimukset tuoneet näkökulmaan mitään uutta. 


\subsection{Tutkimusongelmat ja keskeiset käsitteet}

Seuraavaksi esittelen väitöskirjatyöni tutkimusongelmat ja -kysymykset osatutkimus kerrallaan. Sen jälkeen käyn läpi tutkimuksen keskeiset käsitteet ja pohdin lyhyesti freestyle-lumilautailun ammattikentän tutkimisen mielekkyyttä.

\subsubsection{Ongelmia ja kysymyksiä}

Tämän väitöskirjatyön tutkimusongelma kysyy: millaiset tekijät vaikuttavat suomalaisten freestyle-lumilautailijoiden kiinnittymisessä ammattilaisuuteen? Jaoin tutkimusprosessin aikana tutkimusongelman viiteen osa-ongelmaan:

1. Kuinka suomalaiset lumilautailijat sopeutuvat ammattilumilautailukentän instituutioihin?

2. Millainen on median rooli suomalaisten lumilautailijoiden uralla?

3. Millainen on valmentajien rooli suomalaisten lumilautailijoiden uralla?

4. Millainen rahoitustausta mahdollistaa suomalaisten lumilautailijoiden uran?

5. Millaisia tavoitteita lumilautailijat asettavat urheilu-uralleen?

Jokaiseen osaongelmaan vastaaminen on synnyttänyt väitöskirjatyöhön oman artikkelinsa. Tosin toisessa artikkelissa median roolin tarkastelu suomalaisten lumilautailijoiden kiinnittymisessä ammattilaisuuteen muuttui median roolin tarkasteluun yleisesti nuorisokulttuurisissa lajeissa syistä, jotka selvitän luvussa 3.3. Näin jokainen tutkimuksen artikkeli tuo osavastauksen tutkimuksen ongelmaan, kuten alla oleva taulukko 1 havainnollistaa: 
TAULUKKO 1 Tutkimusongelmat ja niihin vastaaminen artikkeleissa.

\begin{tabular}{|l|l|}
\hline $\begin{array}{l}\text { Lumilautailukentän } \\
\text { instituutiot }\end{array}$ & $\begin{array}{l}\text { Ojala, A.-L. 2014. Institutionalisation in professional } \\
\text { freestyle snowboarding - Finnish professional riders' } \\
\text { perceptions. European Journal for Sport and Society, } \\
11 \text { (2), 103-126. }\end{array}$ \\
\hline $\begin{array}{l}\text { Median } \\
\text { rooli }\end{array}$ & $\begin{array}{l}\text { Ojala, A.-L. \& Itkonen, H. 2013. Median merkitys } \\
\text { nuorisokulttuurisessa liikkumisessa. Nuorisotutki- } \\
\text { mus, 31 (4), 20-35. }\end{array}$ \\
\hline $\begin{array}{l}\text { Valmentajien } \\
\text { rooli }\end{array}$ & $\begin{array}{l}\text { Ojala, A.-L. \& Thorpe, H. 2015. The role of the coach } \\
\text { in action sports: Using a problem-based learning ap- } \\
\text { proach. International Sport Coaching Journal, 2 (1), } \\
\text { 64-71. }\end{array}$ \\
\hline $\begin{array}{l}\text { Uran } \\
\text { rahoitustausta }\end{array}$ & $\begin{array}{l}\text { Ojala, A.-L. Luovan luokan esiinmarssi huippu- } \\
\text { urheiluun : tapaustutkimus suomalaisten ammattilu- } \\
\text { milautailijoiden ja heidän managereidensa näkemyk- } \\
\text { sistä urheilu-uran resursoinnissa. Lähetetty tieteelli- } \\
\text { sen aikakausilehden arvioitavaksi. }\end{array}$ \\
\hline $\begin{array}{l}\text { Lumilautailijoiden } \\
\text { tavoitteet }\end{array}$ & $\begin{array}{l}\text { Ojala, A.-L. \& Itkonen, H. Nautinnonhalu vie voiton- } \\
\text { janon: Lumilautailu ja muuttuvat sosialisaatioympä- } \\
\text { ristöt. Kasvatus \& Aika, 8 (4), 7-19. }\end{array}$ \\
\hline
\end{tabular}

Tutkimuksen kokonaisuuden kannalta ensimmäisen osaongelman ja siten ensimmäisen artikkelin tarkoituksena oli hahmottaa ammattilumilautailun kenttää siitä suunnasta, kuinka kenttä näyttäytyy lumilautailijoille itselleen. Ammattilumilautailukentän instituutioiden tarkastelu tuntui lähestymistavalta, jonka kautta voisi täyttää tämän tavoitteen. Samalla ensimmäisen osatutkimuksen tehtävänä oli paikantaa ne seuraavat osaongelmat, jotka toisivat vastauksia tutkimuksen kokonaisongelmaan eri suunnista.

Tutkimuksen osaongelmien valikoituminen ja rajautuminen tapahtui tutkimusprosessin edetessä. Tarttuminen ammattilumilautailukentän instituutioihin toi minut luonnollisesti lähelle instituutioteorioita; lähelle akateemisen sosiologian alkujuuria. Aineistoa lukiessa huomasin, ettei ammattilumilautailun 
kenttä ollut suinkaan yhtenäinen edes suomalaisten ammattilumilautailijoiden suunnasta katsottuna. Kuten aiemmat tutkimuksetkin (Coates, Clayton \& Humberstone 2010; Thorpe \& Wheaton 2011; Thorpe 2011, 28-29; Thorpe 2012a, 78) osoittavat, nuorisokulttuuriset lajit ovat fragmentoituneita. Myös lumilautailu sisältää useita tyylilajeja ja perinteitä, mutta pyrkimys ilmaisulliseen luovuuteen, vapauteen ja hauskuuteen on ollut lajikulttuurille tyypillistä (esim. Humphreys 1996; 2003). Samalla aineistossa oli lukuisia kommentteja organisoitumisen vaikutuksista lumilautailulle. Halusin ymmärtää lumilautailijoiden kokemuksia ammattilumilautailukentän organisoitumisesta. Ratkaisun löysin uusinstitutionalismista ja ennen muuta W. Richard Scottin (2001) tavasta hahmottaa sosiaalista organisoitumista instituutioiden sekä niitä vahvistavien ja ylläpitävien elementtien kautta. Uus-institutionalismin raameissa ammattilumilautailun kenttää ei tarvinnut pyrkiä hahmottamaan kokonaisuutena, vaan sitä kautta, miten sen eri toimijat rakentavat kentällä legitimiteettiä ja millaisia organisoitumismuotoja he vahvistavat toiminnallaan.

Toisen osa-ongelman muodostuminen oli seurausta ensimmäisen osatutkimuksen tuloksista, mutta myös lukeneisuudestani. Median merkitys niin lumilautailuareenoiden kuin urankin luomisessa näyttäytyi merkittävänä jo ensimmäisessä osatutkimuksessa. Lisäksi mediatutkijat, kuten Winfried Schultz (2004), painottavat medioitumiskehityksen vaikuttaneen yhteiskunnissa siten, että media on nykyään läsnä kaikkialla ja läpäisee kaiken. Nämä mediatutkijoiden väitteet ovat realisoituneet niissä nuorisokulttuurista liikkumista tarkastelleissa tutkimuksissa, joita olin lukenut tutkimuskenttää taustoittaessani. Esimerkiksi liikuntasosiologit Belinda Wheaton ja Becky Beal (2003) huomasivat skeittareiden lukeneen erikoislehtiä oppiakseen tietoa alakulttuurisista arvoista, tyyleistä, tekniikoista ja välineistä. Näin ollen tutkimus lumilautailijoiden kiinnittymisessä ammattilaisuuteen olisi tuntunut tyngältä ilman median roolin tarkastelua. Varsinkin kun myös monet lumilautailua tarkastelevat tutkimukset (Humphreys 1996; Humphreys 1997; Coates, Clayton \& Humberstone 2010) ovat esittäneet lajin vaihtoehtoisena perinteisille lajeille myös siitä syystä, että kilpailemisen voi korvata tekemällä aktiivisesti yhteistyötä erikoismedian kanssa.

Valmentajan rooli lumilautailijoiden kiinnittymisessä ammattilaisuuteen valikoitui kolmanneksi osa-ongelmaksi kahdesta syystä. Vaikka urheilu-termiä on vierastettu lumilautailun ja muiden nuorisokulttuurisen liikkumisen lajeissa varsinkin populaareissa keskusteluissa (esim. Lilja 2013), on ammattilumilautailu ollut vuodesta 1998 myös olympiaurheilua. Toiseksi analysoidessani aineistoa ensimmäisen osatutkimuksen kohdalla huomasin, etteivät lumilautailijat maininneet valmentajia omissa urakertomuksissaan useasti. Vaikka lumilautailun institutionalisoituminen ja varsinkin olympialaiset ovat tuoneet aiempien tutkimusten (Thorpe 2007; Thorpe \& Wheaton 2011; Thorpe 2011) mukaan perinteisille lajeille tyypillisiä piirteitä mukanaan, ei oma aineistoni näyttänyt valmentajaa ainakaan alustavissa tarkasteluissa merkittävänä hyötynä lumilautailijoille. Lumilautailun valtavirtaistumista toistavien tutkimusten ja oman aineistoni valossa katsoin tarpeelliseksi tarkastella myös valmentajien roolia 
suomalaislumilautailijoiden urilla. Valmentautumista tarkasteltaessa lumilautailu vertautuu lajina perinteisiin urheilulajeihin.

Ammattiurheilu ilman rahoitusta ei olisi ammattilaisuutta. Siten neljäs osa-ongelma - suomalaisten lumilautailijoiden uran mahdollistava rahoitustausta - oli itsestään selvä tarkastelukohde tutkimuksen suunnitteluvaiheesta alkaen. Myös viides osa-ongelma, eli lumilautailijoiden urheilu-urien tavoitteet, liittyy urheilu-uraan niin keskeisesti, että aihepiiri oli luontevasti osa tutkimustehtävääni. Viidennen osa-ongelman sisällyttäminen väitöskirjatyöhöni oli lopulta seurausta artikkelimuotoisesta väitöskirjaprosessista. Olin koodannut lumilautailijoiden tavoitteita aineistosta pyrkiessäni hahmottamaan siitä nousevia teemoja kenttäjakson jälkeen. Aihe jäi kuitenkin odottamaan parempaa hetkeä. Artikkelien vertaisarviointiprosessien pitkittyessä minun oli syytä varmistaa tutkimusaikataulussa pysyminen vielä yhdellä käsikirjoituksella. Tällöin nostimme Hannu Itkosen kanssa viidennen osaongelman esille ja aloimme työstää siitä artikkelia.

Mielessäni oli suunnitteluvaiheessa myös muita varteenotettavia tarkastelukohteita, jotka eivät lopulta päätyneet osatutkimuksiini. Esimerkiksi jokaisessa osatutkimuksessa sivutaan urheiluorganisaatioiden roolia suomalaisten lumilautailijoiden kiinnittymisessä ammattilaisuuteen, minkä arvioin tutkimuksen alussa yhdeksi tärkeäksi tutkimuskohteeksi. Väitöskirjatutkimuksen ajallisen rajallisuuden vuoksi osa-ongelman muodostaminen esimerkiksi seurojen ja liiton roolista suomalaislumilautailijoiden urilla oli liikaa. Samoin perhetaustan ja ystävien rooli lumilautailijoiden kiinnittymisessä ammattilaisuuteen olisi kaivannut pohdintaa. Ystävien roolia sivutaan kolmannessa osajulkaisussa, mutta perhetaustan merkitys jää tutkimukseni tarkastelun ulkopuolelle. Toisaalta Outi Aarresola on tehnyt samaan aikaan omaa väitöskirjatutkimustaan, jossa hän on tutkinut vanhempien roolia urheilu-uralle sosiaalistumisessa (Aarresola \& Konttinen 2012a; Aarresola \& Konttinen 2012b).

\subsubsection{Tutkimuksen käsitteet ja ammattilumilautailun tutkimisen mielek- kyys}

Puhuttaessa urheilun huipputasosta käytetään huippu-urheilun termiä. Huippuurheilun sisältö kuitenkin pakenee määrittelyjä, kuten huippu-urheilua Pohjoismaissa kartoittava Opetusministeriön (Lämsä 2004) selvityskin toteaa. Liikuntatieteilijät Sheldon Hanton, David Fletcher ja Guy Coughlan (2005) käyttävät seuraavaa ehtoa valikoidessaan huippu-urheilijoita tutkimukseensa: urheilijan tulee olla sellaiseen kansalliseen edustustasoon kuuluva henkilö, joka on ottanut osaa oman lajinsa kilpailuihin korkeimmalla tasolla. Kilpailuihin viittaaminen onkin huippu-urheilun määrittämisessä tyypillistä (Andersen \& Ronglan 2012). Lumilautailun ja sen tutkimuksen kannalta kilpailuihin nojaava määrittelytapa on ongelmallinen. Lumilautailijoille kilpailut eivät ole ainoita areenoita taitojen esittelyyn ja vertailuun edes lajin huipputasolla. Kilpailuiden lisäksi lumilautailijat esittelevät taitojaan lumilautailumedioissa.

Ammattilumilautailun määritteleminen on lajin monimuotoisuuden vuoksi yksinkertaisempaa kuin lumilautailun huipputason: tässä tutkimuksessa am- 
mattilumilautailija tarkoittaa sellaista lumilautailijaa, joka harjoittaa lumilautailemista työnään, eikä tarvitse muita tulonlähteitä elämiseensä. On toki todettava, etteivät kaikki ammattilumilautailijat välttämättä täyttäisi niitäkään huippuurheilun määritelmiä, joissa kilpailumenestyksen sijasta puhutaan kunkin lajin huipputason saavuttamisesta (ks. esim. Robinson 1985). Puoliammattilaisista puhuessani viittaan niihin lumilautailijoihin, jotka ovat ehkä matkalla ammattilaisiksi, mutteivät vielä saa täyttä toimeentuloa pelkästään lumilautailemalla. Toisaalta puoliammattilaiset voivat olla myös ammattilaisuraansa jäähdytteleviä lumilautailijoita. Ammattilaisten ja puoliammattilaisten ero on näin määriteltynä häilyvä, sillä tiedämme jo kulutussosiologisista tutkimuksista (Aro \& Wilska 2011), että pienillä tuloilla voi tulla hyvin toimeen ja toisaalta suuret tulot voivat tuntua pieniltä elintasovaatimusten ollessa korkeita. Huomasin kuitenkin kerätessäni tutkimuksen aineistoa, etteivät edes haastattelemani lumilautailijat osanneet määrittää, ketkä ovat ammattilaisia ja ketkä puoliammattilaisia. Jotkut tekivät kesäisin sivutöitä silkasta ilosta tai omistivat jonkun yrityksen, josta saivat tuloja. Lisäksi haastatteluhetkellä määritelty status voi muuttua hetkessä loukkaantumisten tai sponsorisopimusten muuttumisen myötä. Näin ollen informanttien määrittely haastatteluhetkellä ammattilaisiksi ja puoliammattilaisiksi kertoo vain sen hetkisen tilanteen, jos sitäkään tyhjentävästi.

Tarkastellessaan lumilautailijoiden kiinnittymistä ammattilaisuuteen tutkimukseni paikantuu urheilijan urasta kiinnostuneeseen tutkimusperinteeseen. Urheilijan uran siirtymävaiheita sekä yksilön ominaisuuksia ja olosuhteita on tutkittu runsaasti varsinkin psykologisin (Wylleman, Alfermann \& Lavallee 2004; Alfermann \& Stambulova 2007; Barker et al. 2014) suuntauksin. On ymmärrettävää, että urheilijan uraa on kartoitettu paljon kehityspsykologisesta näkökulmasta ja pohdittu niitä ominaisuuksia ja olosuhteita, jotka johtavat huipulle. Näihin olosuhteisiin kuuluvat myös ammattimaisen urheilu-uran käytännön järjestelyt kunkin lajin organisoitumismuotojen ja lajikulttuurin kontekstissa. Kulttuuritutkimuksen yhteiskuntatieteellisen nousun myötä kulttuurisen kontekstin tarkastelu on huomioitu hiljalleen urheilijoiden uraa koskevassa kirjallisuudessa (Stambulova \& Alfermann 2009; Ryba \& Stambulova 2013). Silti esimerkiksi urheilijan lajikulttuurisen kontekstin ja rahoitusjärjestelyjen pohtiminen on herättänyt tutkijoiden kiinnostusta huomattavan vähän. Näitäkin tutkimuksia on toki tehty (esim. Kahma 2012; Kärmeniemi, Lämsä \& Savolainen 2013; Piispa \& Huhta 2013). Esimerkiksi Mikko Piispa (2013) toteaa suomalaisten huippu-urheilijoiden elämänkulkuja tarkastelevassa tutkimuksessaan urheilu-uran vaativan perheeltä keskimääräistä parempaa taloudellista taustaa, sillä harjoitteluun keskittyminen on myös taloudellinen riski.

Lumilautailuammattilaisuutta sivutessaan liikuntasosiologi Duncan Humphreys esitti vuonna 1996, että lumilautailuun kehittyi skeittausbisneksestä kopioitu ammattilaisuuden muoto, jossa kilpaileminen ei ole yhtä välttämätöntä kuin sopivan imagon ylläpito. Myös liikuntasosiologi Holly Thorpe (2011, 55) tulkitsee lumilautailun ruumiillisuutta tarkastelevassa kirjassaan ammattilumilautailijat yritysten palkkaamina makukulttuurin manipuloijina. Makujen ohjailu onnistuu siitä syystä, että miespuoliset ammattilumilautailijat ovat lumi- 
lautailukentän hierarkian huipulla ja päättävät, mikä kulloinkin on arvostettua (Thorpe 2010). Sponsorisopimuksiksi muuntuva arvostus aiheuttaa kuitenkin monenlaista painetta ja vaatimuksia, jolloin lumilautailija ei ole enää vapaa päättämään ruumilllisuudestaan ja lajistaan itse (Thorpe 2011, 56-59; Coates, Clayton \& Humberstone 2010).

Vaikka edellä esitellyt tutkimukset tarjoavat useita mielenkiintoisia näkökulmia nuorisokulttuuristen liikkumismuotojen mahdollistamiin urapolkuihin, jättävät ne avoimiksi useita kysymyksiä. Gregory J. Snyder (2012) toteaa skeittaustutkimuksessaan, että nuorisokulttuurisia lajeja on järkevää tarkastella alakulttuureina jopa ammattiurheilun tapauksessa, vaikka alakulttuurin teoriat ovat tarjonneet huonot välineet kaupallisuuden ja alakulttuurien yhteistyön hahmottamiseen. Myös lumilautailun alakulttuurisuuden ja kaupallisuuden yhteistyö vaatisi tutkimusta, sillä lumilautailu on merkittävä bisnesala (Thorpe 2011, 51-56). Alakulttuurien sisäisten markkinoiden tutkimuksia ei kuitenkaan ole tehty. Lisäksi nuorisokulttuuristen lajien fragmentoituneisuuden empiirinen tarkasteleminen on jäänyt toistaiseksi tekemättä, vaikka tutkijat ymmärtävät lajien sisältävän paljon erilaisia tyylejä, harrastajaryhmiä ja muuttuvuutta (Coates, Clayton \& Humberstone 2010; Thorpe \& Wheaton 2011; Thorpe 2011, 28-29; 2012a, 78; Snyder 20012). Tämä tutkimus nojaa aiempien tutkimusten löydöksiin lajien fragmentoituneisuudesta sekä alakulttuurien ja kaupallisuuden yhtymäkohdista, ja tarttuu samalla yhtä nuorisokulttuurista lajia laajempiin liikuntatieteellisiin ja sosiologisiin kysymyksiin.

Suomalaisessa liikuntatutkimuksen perinteessä on totuttu puhumaan eriytymisen käsitteestä fragmentoitumisen sijasta (esim. Itkonen 1996; Mäkinen 2010; Kokkonen 2013, 106). Koin eriytymisen käännöksen (differentiation) tuovan varsinkin englanninkielisissä osatutkimuksissani mielleyhtymän Talcot Parsonsin (1951) ja Niklas Luhmanin (1977) systeemiteorioista. Halusin ottaa osaa ennen muuta nuorisokulttuurisen liikkumisen tutkimuskeskusteluihin, minkä vuoksi käytin eriytymisen sijasta niille tuttua fragmentoitumisen käsitettä. Artikkeleihini valikoituneet teoriat ja teoreettiset käsitteistöt tuntuivat selkeämmiltä ilman mielleyhtymiä laajoihin systeemiteorioihin.

Väitöskirjatyöni keskittyy freestyle-lumilautailuun siitä syystä, että se on Suomen pienten mäkien ja vähäisen lumimäärän vuoksi suomalaislumilautailijoille itsestään selvin lumilautailun muoto. Freestyle-lumilautailulla tarkoitetaan skeittauksesta vaikutteensa saanutta lumilautailun osa-aluetta, jossa keskeisen tavoitteen muodostavat teknisten ja tyylikkäiden temppujen suorittaminen (pääsääntöisesti) ihmisten tekemissä suorituspaikoissa (Thorpe 2011, 29). Freestyle-lumilautailu on tutkimusilmiönä erityisen kiinnostava siksi, että juuri tämä lumilautailun osa-alue yhdistää nuorisokulttuuriselle liikkumiselle tyypilliset arvot ja asenteet olympiaurheiluun. Näin ollen tutkimukseni tarkastelee sellaista kenttää, jossa muutos on nopeaa ja lajista kiinnostuneita osapuolia on paljon. Tämä asetelma tekee tutkimuksesta sekä mielenkiintoisen että haastavan.

Käytän sosiologi W. Richard Scottin mallin mukaisesti kenttää metodologisena käsitteenä viitatessani organisatoriseen kenttään, joka sitoo niitä olosuhtei- 
ta ja ympäristöjä, joissa ammattilumilautailu tapahtuu, ja joissa ammattilumilautailun institutionaaliset prosessit toimivat (Scott 2001, 43). Tämä kenttä ei ole Scottin (2008) näkemyksiä noudatellen yhtenäinen, muuttumaton tai selvärajainen, vaan sitoo ympärilleen alakulttuurista poikkeavasti myös ne toimijat, jotka eivät tunnista lumilautailun alakulttuuriin liittyviä asenteita ja arvoja, mutta mahdollistavat - vaikka vain hetkellisesti - ammattilumilautailun olemassaolon. Tämä kenttä pitää sisällään myös ammattilumilautailun areenat, joilla tarkoitan niiden todellisten tapahtumapaikkojen ja medioiden yhdistelmiä, joiden kautta ammattilumilautailijat näyttävät taitojaan, ja joiden kautta lumilautailun kehitys tulee yleisöjen eteen kilpailuina, TV-lähetyksinä, sanomalehdissä, lumilautailuvideoissa, erikoislehdissä ja sosiaalisessa mediassa. 


\section{TUTKIMUKSEN TEOREETTINEN PERUSTA}

Esittelen tässä luvussa ne teoriat, jotka ovat olleet keskeisiä omalle tutkimukselleni. Aloitan katsauksen alakulttuurin tutkimuksista, joista siirryn instituutiotutkimusten kautta valmennustutkimuksiin sekä huippu-urheilua ja ammattilaisurheilua raamittaviin tutkimuksiin.

\subsection{Lumilautailu ja alakulttuurintutkimus}

Lumilautailua lähestytään tutkimuksissa liki poikkeuksetta liikkumisen ilmiönä, jossa on varsinkin lajin alkuaikoina ollut perinteisestä urheilukulttuurista poikkeavia ja sitä vastustavia ilmaisullisia ja aatteellisia muotoja (ks. esim. Humphreys 1996; 2003; Thorpe \& Wheaton 2011). Sosiologi Dick Hebdigen $(1979,2)$ klassikkotutkimuksen mukaan tällöin voidaan puhua alakulttuureista. Vaikka Hebdige $(1988,35)$ kritisoi myöhemmin itsekin vastustuksen ja kaupallistamisen ehdottomuutta omassa alakulttuurinäkemyksessään, tarjoaa hänen alakulttuurimääritelmänsä hyvän lähtökohdan lumilautailun alakulttuurisuuden pohdinnalle. Koska hallinnan ja vastustuksen tematiikka on ollut läsnä aiempien lumilautailututkimusten määrittämän lumilautailun aatemaailman vuoksi jokaisessa osatutkimuksessani, koen lumilautailun tarkastelun alakulttuurintutkimuksen kontekstissa tarpeelliseksi. Ensimmäisessä alaluvussa peilaan lumilautailua alakulttuurin teorioiden kautta. Toisessa alaluvussa tarkastelen lumilautailun alakulttuurista pääomaa, joka toimi keskeisenä käsitteenä kolmannessa osatutkimuksessa.

\subsubsection{Lumilautailu alakulttuurina}

Hallinnan ja vastustuksen kautta syntyvä kulttuuri on kiinnostanut kulttuurintutkijoita jo kauan. Erityisesti tämä asetelma on herättänyt kiinnostusta alakulttuurintutkijoissa. Kiinnostus alakulttuurin ilmiöön ja käsitteeseen on ollut niin suurta myös liikuntatieteen alalla, että alakulttuurisuudella on selitetty monen- 
laisia ilmiöitä. Käsitteen selitysvoima on heikentynyt. (Crosset \& Beal 1997.) Kulttuurien fragmentoitumisen, kulutustottumusten muuttumisen, elämäntapojen nopean muutostahdin sekä median merkityksen ja tyylittelyn huomioiminen varsinkin nuorison elämäntavoissa on tuonut tutkimuksiin alakulttuurin haastavia uusia käsitteitä ja lähestymistapoja. Jälkialakulttuurisuudeksi kutsutun koulukunnan (Bennett \& Kahn-Harris 2004) tutkijat alkoivat puhua liikuntatieteissäkin skeneistä, uusheimoista, makukulttuureista, elämäntaparyhmistä ja figuraatioista alakulttuurin sijasta (Young \& Atkinson 2008). Tässä tutkimuksessa olen kuitenkin päättänyt käyttää alakulttuurin käsitettä liikuntasosiologi John Hughsonin (2008) esittämään perusteluun tukeutuen: on turha hylätä vanhaa käsitettä vain siksi, että maailma on muuttunut tai käsite ei ole tyhjentävä; myös käsitteitä tulee kehittää tieteen ja yhteiskunnan kehittyessä.

Alakulttuuri-termi viittaa sosiologi Milton J. Yingerin (1960) uraauurtavan esseen mukaan arvoiltaan, ideologioiltaan tai toimintatavoiltaan valtakulttuurista poikkeavaan ryhmään, joka ei saa vastakulttuurin tavoin koko energiaansa valtavirran vastustuksesta. Valtavirran käsite muodostuu alakulttuurille olennaiseksi juuri Yingerin (1960) esittämästä syystä: rajatun ryhmän jäsenet voivat herkästikin kokea oman elämäntapansa valtavirrasta poikkeavaksi, mutta alakulttuuria elämäntavasta tulee vasta silloin, kun valtavirta marginalisoi sen. Lumilautailun osalta tämä voisi tarkoittaa sitä, ettei lumilautailijoiden yleinen kapinointi vaikkapa Kansainvälisen Hiihtoliiton toimintatapoja vastaan FUCK FIS -tarroja liimailemalla tee lumilautailusta yksistään alakulttuuria, mutta Kansainvälisen Hiihtoliiton käytäntö noteerata lumilautailusta vain valtavirtayleisön ymmärtämät kilpailuformaatit yhdistettynä lumilautailijoiden kapinointiin tekee. Näin alakulttuuri on olemassa sekä alakulttuurin sisäisten toimien että alakulttuurin ulkopuolisen yhteiskunnan reagoinnin seurauksena. Samalla hallinnan ja vastustuksen tematiikka on alakulttuurin käsitteeseen niin vahvasti sisäänrakennettu, että tutkijoiden tehtäväksi on jäänyt Crossetin ja Bealin (1997) mukaan vain arvailla, mikä eletyissä kulttuureissa on hallintaa tai myötäilyä ja mikä vastustusta.

Alakulttuurien syntyä ja niihin liittymistä on tulkittu eri teoriaperinteissä poikkeavasti. Chicagon koulukunnan näkemyksissä alakulttuurit syntyivät yksilöiden sosiaalisista olosuhteista ja reaktioista yhdenmukaisuuden vaateisiin. Esimerkiksi Albert K. Cohen (2005 [1955]) tulkitsee ihmisten kehitykseen vaikuttavan sen, että he kokevat saavansa hyväksyntää näkemyksilleen ja olemukselleen jossain tietyssä ryhmässä. Näistä kanssakäymisistä syntyy pieniä maailmoja sosiaalisen maailman sisälle. Vaikka alakulttuureissa itseään toteuttavat nuoret ovat chicagolaisten näkemyksissä luovia, ratkaisukeskeisiä ja vapaudestaan neuvottelevia, ovat he myös sidoksissa sosioekonomiseen asemaansa (ks. Puuronen 1997, 65-73; 92-98). Samoin birminghamilaisessa teoriaperinteessä, eli brittiläisessä kulturalismissa alakulttuurit nähdään sidosteisina luokkaperustaansa. Alakulttuurien synty ja viehätys selitetään kuitenkin chicagolaisista poikkeavasti myös massakulttuurin ja keskitien kulkemisen vastustamisella (Gelder 2005). Sosiologit John Clarke, Stuart Hall, Tony Jefferson \& Brian Roberts (2005 [1975]) tulkitsevat, että luokkasidonnainen emokulttuuri antaa nuo- 
rille välineitä käsitellä laajoja kokonaisuuksia, kuten sukupuolirooleja, jolloin luokkasidonnaisia arvoja ja merkityksiä uusinnetaan myös alakulttuureissa. Räikeäkin tyylittely nähdään ennen muuta alakulttuurisen identiteetin rakentamisen ja ylläpidon välineenä, joka ilmentää myös sen jäsenten luokkataustaa. (Puuronen 2006, 113-114.)

Huolimatta amerikkalaisista ja brittiläisistä alakulttuuritutkimuksen perinteistä, olen tässä tutkimuksessa käsitellyt alakulttuuria luokkataustasta riippumattomana ilmiönä. En kuitenkaan halua tulkita, ettei lumilautailijoiden luokkataustoilla olisi mitään merkitystä heidän urapoluillaan. Esimerkiksi Sune Q. Jensen (2006) osoittaa tanskalaisnuoria tarkastelevassa tutkimuksessaan, että luokalla, sukupuolella ja etnisellä taustalla on merkitystä siinä, mitä tulkitaan kussakin ryhmässä alakulttuuriseksi pääomaksi. Alakulttuurinen pääoma vaikutti samassa tutkimuksessa siihen, millaisia elämänpolkuja nuoret ohjautuivat kulkemaan. Luokkataustaisuuden syvempi pohdinta lumilautailijoiden urapoluilla olisi vaatinut kuitenkin oman osa-tutkimuksensa, eikä siihen ollut väitöskirjani raameissa mahdollisuutta.

Lumilautailututkimuksissa hallinnan ja vastustuksen tulkitseminen on ollut hyvin yleistä. Historiaan keskittyvät tutkimukset huomioivat muun muassa hiihtokeskusten lumilautailukiellot (Humphreys 1996; 1997; Howe 1998, 39-41; Thorpe 2007; 2011, 23) ja valtavirtamedian paheksunnan (Humphreys 1996; Thorpe 2011; 79-80) alakulttuurin ja valtakulttuurin neuvotteluina. Organisoitumismuotoja tai valtasuhteita pohtivat tutkimukset taas keskittyvät valtavirtaurheilusta poikkeaviin areenoihin, joita urheilu- ja mediaorganisaatiot pyrkivät hyödyntämään omiin tarkoituksiinsa alakulttuurin areenojen monimuotoisuudelle kohtalokkain seurauksin (Humphreys 2003; Popovic 2006; Coates, Clayton \& Humberstone 2010; Thorpe \& Wheaton 2011). Lumilautailun ruumiillisuutta tarkastelevat tutkimukset tuovat esiin varsinkin hiihtolajeista poikkeavan ilmaisutapojen luovuuden, tyylin ja muutostahdin (Humphreys 2003; Thorpe 2009c; Thorpe 2011, 121-122). Omassa tutkimuksessani olen käyttänyt tausta- ja tulkintakehikkona kaikkia edellä esitettyjä alakulttuurisuuden ilmenemismuotoja, mutta huomioinut ennen muuta lumilautailukulttuurissa kannatetut arvot ja asenteet. Olen kutsunut näitä asenteita ja arvoja ensimmäisessä osatutkimuksessani lumilautailun perinteiseksi eetokseksi. Aiemmat tutkimukset ovat esittäneet lumilautailun alakulttuurin kannustavan hauskuuteen, luovuuteen, vapauteen, omaehtoisuuteen ja auktoriteettivastaisuuteen, mikä on yhtäaikaisesti viehättänyt alakulttuurin ulkopuolisia toimijoita sekä aiheuttanut paheksuntaa (Humphreys 1996; 2003; Beverland, Farrelly \& Quester 2010; Thorpe \& Wheaton 2011; Thorpe 2007; 2009c; 2011, 23).

Lumilautailun kohdalla on syytä erottaa Peter Donnellyn (1990) näkemyksin alakulttuuri (lumilautailu), emokulttuuri (hegemoninen urheilukulttuuri) ja valtakulttuuri (hegemonista urheilukulttuuria ympäröivät kulttuuriset järjestelmät) toisistaan (vrt. Puuronen 2006, 113). Tämä siksi, että lumilautailututkimukset ovat esittäneet lumilautailun alakulttuurisuuden muodostuneen arvojen ja asenteiden osalta ennen muuta alakulttuurin ja emokulttuurin välillä käydyissä neuvotteluissa. Samalla tutkimukset ovat jättäneet hyvin vähälle 
pohdinnalle sen eron, kuinka lumilautailun alakulttuuri syntyy lumilautailijoiden ja emokulttuurin, ja toisaalta lumilautailijoiden ja valtakulttuurin välisissä neuvotteluissa. Toisin sanoen lumilautailun poikkeavuus hiihtokulttuurista ja lumilautailun liittäminen olympialaisiin on huomattu monissa tutkimuksissa (esim. Humphreys 1996; 1997; Howe 1998, 39-41; Thorpe 2007; 2011, 23; Popovic 2006), mutta yhteiskunnan makrotason vaikutus lumilautailun alakulttuurin muodostumiseen ja ylläpitoon on jäänyt pohtimatta (kuitenkin Humphreys 1996; 1997; 2003). Samalla tutkimukset ovat kuvanneet lumilautailun valtavirtaistumista unohtaen sen, ettei valtavirtaistuminen ole välttämättä totaalista (ks. Donnelly 1990; Crosset \& Beal 1997). Alakulttuurit kykenevät keksimään uusia vastustuksen muotoja, joihin emo- ja valtakulttuurit reagoivat tai ovat reagoimatta.

Lumilautailun alakulttuurille tyypillisillä arvoilla ja asenteilla olen selittänyt ensimmäisessä osatutkimuksessani lumilautailijoiden suhtautumista ammattilumilautailukentän organisoitumismuotoihin ja institutionaalisiin elementteihin. Toisessa osatutkimuksessa laajensimme Hannu Itkosen kanssa tutkimuskohteen koskemaan lumilautailun sijasta nuorisokulttuurista liikkumista yleensä, ja tutkimuksen analyysityökaluksi valikoitui alakulttuurinen pääoma erontekojen välineenä. Tästä työkalusta kerron lisää seuraavassa alaluvussa. Kolmannessa osatutkimuksessa tulkitsimme Holly Thorpen kanssa lumilautailijoiden valmentajanäkemysten selittyvän jälleen lumilautailussa vallitsevilla arvoilla ja asenteilla. Neljännessä osatutkimuksessa selitin tietynlaisen resursointimallin kehittymistä ammattilumilautailuun valtakulttuurin ja lajin otollisilla arvoilla ja asenteilla. Viimeisessä osatutkimuksen tarkasteluissa lumilautailun asenteet ja arvot luovat historisen taustan lumilautailijoiden tavoitteille. Näin ollen alakulttuurisuus on ollut monin tavoin mukana tutkimusasetelmissa, vaikka alakulttuuriteoriat eivät ole olleet analyysityökaluna kuin toisessa osatutkimuksessa. Samalla voin todeta tutkimukseni olleen rakenteiden korostamisen ja toimijuuden vähäisen huomioimisen vuoksi suomalaiseen sosiologiseen perinteeseen tyypillinen (Alapuro 2006).

\subsubsection{Alakulttuurinen pääoma lumilautailun kentällä}

Ranskalainen sosiologi Pierre Bourdieu löi läpi erottautumismekanismeihin perustuvalla kokonaisteoriallaan, jossa nähdään sosiaalinen maailma kenttinä, joilla yksilöt pyrkivät kartuttamaan arvostettuja pääomia (Bourdieu 1984). Liikuntatieteilijät ovat suhtautuneet Bourdieun näkemyksiin suopeasti. Tarjoavathan hänen ajatuksensa habituksesta ja hexiksestä - eli ulospäin näkyvistä, asenteisiimme, valintoihimme ja sopeutumiseemme vaikuttavista, ruumiillistuneista elämänhistorioista - mahdollisuuden sosiaalisen rakenteen ja yksilötason yhdistämiseen siten, että kehollisuuden rooli huomioidaan. Bourdieu oli kuitenkin tarkka habituksen luokkasidonnaisuudesta ja muuttumattomuudesta. Bourdieun tulkitsemana habitus ei muuttunut edes nuoruuden vertaisryhmien vaikutuksista (ks. esim. Kivinen 2006), mikä tekee hänen käsitteidensä käytön nuorisokulttuurisen liikkumisen analysoimisessa hankalaksi. 
Englantilainen sosiologi ja kulttuurintutkija Sarah Thornton (1996) keksi yhdistää Bourdieun pääomanäkemykset ja chicagolaisen alakulttuurintutkimuksen tarkastellen alakulttuureita makukulttuureina. Hänen yksi keskeisistä löydöksistään oli nähdä media merkittävänä tekijänä alakulttuurien muodostumisessa. Thorntonin lähestymistapa mullisti mahdollisuuden tulkita resurssien strategista hyödyntämistä luokkataustasta riippumattomin oletuksin medioituneessa maailmassa. Tästä syystä koin Thorntonin lähestymistavan lumilautailun tutkimiseen toimivaksi.

Thornton (1996, 8-9) vaikuttui Howard Beckerin jazztutkimuksesta, jossa ihmiset luokittelivat toisiaan sisäpiiriläisiksi ja ulkopuolisiksi, ja sovelsi kyseistä näkökulmaa tanssiklubien kulttuureihin. Alakulttuurinen pääoma perustuu ajatukselle autenttisuudesta ja "cooliudesta" tietyssä kontekstissa. Lumilautailukulttuurissa alakulttuurinen pääoma olisi juuri sen ruumillistunutta ymmärtämistä ja toteuttamista, mikä on siistiä ja arvostettua lumilautailijoiden keskuudessa (Thornton 1996, 3). Alakulttuurista pääomaa omatessaan lumilautailijat palkitaan hyväksynnällä, statuksella ja arvostuksella sellaisten ominaisuuksien, tyylien ja tiedon omistamisesta, toteuttamisesta ja ymmärtämisestä, mikä erottaa heidät epäautenttisesta "massasta" (Jensen 2006). Todellisuudessa kukaan ei kuitenkaan koe kuuluvansa tähän massaan, josta alakulttuurisen pääoman turvin tehdään eroa. Massa vain sattuu olemaan helpoin vastavoima sille, mihin ei haluta kuulua. (Thornton 2005 [1995].)

Lumilautailun alakulttuurin perustuessa - antropologi Gregory J. Snyderin (2012) skeittaustutkimusta soveltaen - tietylle ruumiilliselle liikekielelle, on lumilautailutaitojen omaksuminen alakulttuuriin kuulumisessa välttämätöntä. Kuitenkin liikkumisen alakulttuuri merkitsee paljon muutakin kuin fyysisiä suorituksia alakulttuurin jäsenille. Samojen arvojen ja asenteiden jakaminen porukan kesken sekä "hengaaminen" hyvässä porukassa tekee harrastamisesta mielekästä (Turner 2013). Näin ollen lumilautailijoille tärkeitä arvoja, asenteita ja tyylillisiä merkityksiä jaetaan myös fyysisten lumilautailusuoritusten ulkopuolella. Antropologi Riitta Hännisen $(2012,67)$ mielestä lumilautailijoita ei olekaan syytä rajata selkeäksi ryhmäksi vaikkapa lumilautailukokemuksen perusteella.

Lajiteknisten taitojen tarpeellisuus tulkitaan lumilautailututkimuksissa skeittaustutkimusten tapaan välttämättömänä alakulttuurisen pääoman kartuttamisessa. Sosiaalistumalla lumilautailun alakulttuuriin sen jäsenet oppivat alakulttuurin hierarkiat, joissa lumilautailutaidot ovat keskeisiä (Thorpe 2011, 133-134). Voitaisiinkin sanoa, että viimeisimmät lumilautailutekniikat ja -tyylit ovat juuri ne alakulttuurisen pääoman muodot, jotka eivät ole kaikille alakulttuurin jäsenille opetettavissa. Näin ollen lumilautailutaidot toimivat hyvin erottautumisen välineenä. Koska ammattilumilautailijoilla on eniten aikaa ja mahdollisuuksia omien pääomiensa esittelyyn ja lumilautailutaitojen opetteluun, on heillä yleensä myös eniten valtaa lumilautailumakujen ja tyylien määrittämisessä (Thorpe 2010, 188).

Alakulttuureihin sosiaalistumista tapahtuu myös median välityksellä, kuten Thornton (1996) huomasi. Tämä oli oman tutkimukseni kannalta tärkeä 
seikka. Lumilautailua seuraava yleisö voi olla kiinnostunut lajista joko mediayleisönä tai oman harrastuksen kautta. Epäilemättä eri yleisöillä on erilainen motivaatio ymmärtää lumilautailusuorituksia ja seurata lajia. Valtavirtamedia tarjoaa lumilautailua yleisölle samojen jakelukanavien kautta kuin muutakin urheilua, eli laji on helposti alakulttuurin ulkopuolisen yleisön seurattavissa. Lisäksi tarjonta on helposti ymmärrettävää. Alakulttuurissa autenttisemmaksi luokiteltua tietoa saadakseen harrastajat seuraavat erikoismediaa, jonka rooli puhetapojen, tyylien ja lajitekniikoiden opettajana on nopeasti kehittyvässä lumilautailussa keskeinen (Thorpe 2011, 129). Valtavirta- ja erikoismedian lisäksi Thornton (1996, 137-151) noteeraa vielä kolmannen mediamuodon, mikromedian. Se tarjoaa tietoa paikallisille alakulttuurin harrastajille alakulttuurissa tärkeistä tapahtumista julisteiden ja mainoslehtisten muodossa.

Jos mediayleisöt niin alakulttuurin sisällä kuin ulkopuolellakin saavat erilaisia tietoja nuorisokulttuurista lajeista eri medioiden kautta, on eri mediamuodoilla Thorntonin (1996) mukaan myös suuri merkitys alakulttuurin ylläpitämisessä. Koska alakulttuurinen ärsytys ja emo- tai valtakulttuurin reagointi on alakulttuurin kannalta välttämätöntä, voi nuorisokulttuurisen liikkumisen aiheuttama pahennus valtavirtamediassa vahvistaa alakulttuurin identiteettiä. Tämä prosessi vahvistaa alakulttuurin erilaisuutta ympäröivästä kulttuurista. Näin alakulttuuri rakentuu myös valtavirtamedian moraalisten paniikkien ja niihin reagoivan alakulttuurisen median kautta (McRobbie \& Thornton 1995). Alakulttuurin sisäiset mediat taas ylläpitävät kulttuuria viestimällä, luokittelemalla ja nimeämällä kaikkea mikä on noteeraamisen arvoista (Thornton 1996, 151).

Median vahva rooli alakulttuurien muodostumisessa ja ylläpidossa tarkoittaa myös lumilautailun kohdalla epäilemättä sitä, että erilaiset mediamuodot vaikuttavat eri tavoin lumilautailun merkityksiin, rakenteisiin ja käytäntöihin. Lähdimme tarkastelemaan kyseistä roolia nuorisokulttuurisen liikkumisen kontekstissa Hannu Itkosen kanssa tehdyssä toisessa osatutkimuksessa, jossa analysoimme aiempien tutkimusten löydöksiä. Thornton ei vielä vuonna 1996 ilmestyneessä tutkimuksessaan avannut internetvälitteisen median asemaa alakulttuurien ylläpidossa ja muodostumisessa. Koska myöhemmissäkään tutkimuksissa ei ole päivitetty Thorntonin teoreettista viitekehystä internetaikakaudelle, oman tutkimuksemme analyysivaihe hankaloitui. Internetin merkitys alakulttuurisessa viestinnässä on tiettävästi hyvin tärkeä nykyajan nuorisokulttuurisessa liikkumisessa. Verkkoviestinnän merkityksistä emme kuitenkaan saaneet kunnolla otetta.

\subsection{Uusinstitutionalismi ammattilumilautailukentän hahmottamisvälineenä}

Instituutio kuuluu sosiologisen tutkimuksen peruskäsitteistöön. Organisaatio- ja instituutiotutkimuksen yhteistyö alkoi kunnolla 1970-luvulla, kun instituu- 
tiotutkimus muodostui hallitsevaksi lähestymistavaksi organisaatioita tarkasteltaessa (Greenwood et al. 2008). Tätä väljästi fokusoitunutta tutkimussuuntausten yhdistelmää on kutsuttu uusinstitutionalismiksi.

Ajatus uusinstitutionalismin mahdollisesta hyödystä omalle tutkimukselleni heräsi sen kautta, että kyseisen suuntauksen teoreetikot ovat tutkineet muun muassa sääntöjen ja säätelyn legitimiteettiä. Lumilautailuun varsinkin urheiluorganisaatioiden kautta vaikuttavat säädökset tuntuivat olevan näkyvästi esillä aineistoni lisäksi myös aiemmissa tutkimuksissa (esim. Humphreys 2003; Popovic 2006; Thorpe \& Wheaton 2011) ja lumilautailumedian keskusteluissa (esim. Wittlake 2011; Haakonsen 2014). Koin uusinstitutionalismin tarjoavan välineitä sen ymmärtämiseksi, kuinka ammattilumilautailijat sopeutuvat ammattilumilautailukentän instituutioihin, ja kuinka organisoituminen vaikuttaa lumilautailijoiden kokemuksiin mahdollisuuksistaan ilmaista itseään luovuuteen, vapauteen ja hauskuuteen kannustavassa lajissaan.

Seurasin osatutkimuksessani W. Richard Scottin $(2001,2008)$ mallia instituutioista ja institutionaalisista elementeistä. Scottin $(2001,49)$ mukaan instituutiot ovat monimuotoisia, sosiaalisista toiminnoista, symbolisista osasista ja materiaalisista resursseista muodostuvia rakennelmia, jotka ovat institutionaalisten elementtien vuoksi suhteellisen pysyviä. Institutionaaliset elementit Scott $(2001 ; 2008)$ on nimennyt regulatiivisiksi, normatiivisiksi ja kulttuuriskognitiivisiksi. Regulatiiviset elementit viittaavat sanktioin vartioituihin lakeihin ja sääntöihin, joita ylläpidetään hallinnollisin järjestelmin. Normatiiviset elementit ovat Scottin mallissa moraalisesti hallinnoituja arvoja ja odotuksia, jotka näkyvät esimerkiksi ammattirooleissa ja velvollisuuksissa. Kulttuuriskognitiiviset elementit tarkoittavat itsestäänselvyyksiä ja jaettua ymmärrystä. Vaikka instituutiot ovat suhteellisen pysyviä, voi niiden legitimaatioperusta muuttua ajan ja sosiaalisen järjestyksen muuttuessa. (Scott 2001, 51-77.)

Oma tutkimukseni rakentui tarkastelemalla lumilautailijoiden näkemyksiä ammattilumilautailukentän organisoitumisesta, minkä toteutin keskittymällä institutionaaliisiin elementteihin. Jos institutionaaliset elementit rakentavat legitimiteettiä, mutta saattavat olla keskenään ristiriitaisia toimijoiden pyrkiessä omiin tavoitteisiinsa omista lähtökohdistaan, syntyy kentälle valtasuhteita (Lawrence 2008; Westenholz 2009). Nämä valtasuhteet vaikuttavat lumilautailukentän rakenteisiin ja lumilautailijoiden mahdollisuuksiin toteuttaa itseään lumilautaillessaan ja urapoluillaan.

Kuten sosiologi Thomas B. Lawrence (2008) osoittaa, instituutiot kantavat valtarakennelmia siten, että sosiaalinen järjestelmä suosii tietynlaista toimintaa, rooleja ja ajatusmalleja, eli tarjoaa tietynlaisen kontekstin toiminnalle. Valtarakennelmia voi syntyä esimerkiksi resurssien dominoimisen kautta: kilpailuorganisaatio tai kuvausryhmä voi päättää siitä, ketkä lumilautailijat pääsevät mukaan kilpailuihin tai kuvauksiin ja millä ehdoilla. Toisaalta lumilautailijoilla on valtaa valitessaan, mihin he haluavat ottaa osaa ja neuvotellessaan ehdoista. Näitä valtamuotoja Lawrence (emt.) kutsuu episodisiksi vallan muodoiksi. Lawrencen systeemisen vallan muodoiksi kutsumat sosialisaatioprosessit taas näkyvät lumilautailijoille tyypillisissä asenteissa ja hierarkioissa, joista esimerkiksi lumi- 
lautailututkijat Duncan Humphreys (2003) ja Holly Thorpe (2010) ovat puhuneet tutkimuksissaan. Jottei lumilautailun valtakenttä näyttäytyisi liian yksinkertaisena, otin tutkimuksessani huomioon skandinaaviseksi institutionalismiksi kutsutun näkemyksen, joka painottaa toimijoiden aktiivista suhdetta maailmaan. Lumilautailijat eivät vain sosiaalistu, neuvottele tai alistu, vaan myös muuttavat merkityksiä, asenteita, käytäntöjä ja symboleja omiin tarkoituksiinsa sopiviksi omaksuessaan niitä. Tätä prosessia instituutiotutkijat Kerstin Sahlin-Andersson (1996) ja Guje Sevón (1996) kutsuvat ideoiden käännösprosessiksi (translation). Kuitenkin tätä ideoiden käännösprosessia - jota Kerstin Sahlin ja Linda Wedlin (2008) kutsuvat jatkuvassa muodossaan editoimiseksi - ohjaavat instituutioiden muuttumista rajoittavat rakenteet. Näiden rajoitusten myötä lumilautailijakin asettuu itseilmaisumahdollisuuksissaan osaksi laajempaa rakenteiden kontekstia.

Ammattilumilautailukentän lähtökohta institutionaalisten elementtien ja ideoiden käännösprosessien analysoimiseksi on mielenkiintoinen, sillä fragmentoituneessa lumilautailukentässä mahdollisia areenoita monien kilpailukiertueiden ja mediatuotantojen vuoksi on monia. Siksi käännösprosesseja voi tapahtua eri tavoin tyylien, osallistumistapojen, tekniikoiden ja asenteiden vaihdellessa. Näin ollen lumilautailijoilla voi olla perinteisten lajien urheilijoita enemmän keinoja pitää lajinsa monimuotoisena huolimatta kentän vakiintumisen aiheuttamasta homogenisoitumisesta, minkä sosiologit Paul J. DiMaggio ja Walter W. Powell (1983) diagnosoivat teoreettisessa tutkimuksessaan.

\subsection{Valmennus harrastajien kontrollia kannattavassa lajissa}

Avaan seuraavassa alaluvussa ongelmakeskeistä oppimisstrategiaa, joka sopi lumilautailun arvoihin ja lumilautailijoiden asenteisiin valmentajien roolia tarkastelevassa osatutkimuksessamme. Lisäksi käyn lyhyesti läpi vertaisvalmennuksen ja mentoroinnin käsitteitä omassa alaluvussaan osatutkimuksen empiriasta nousseiden havaintojen vuoksi.

\subsubsection{Ongelmakeskeinen oppimisstrategia lumilautailukulttuuriin sopivana valmennusmetodina}

Ongelmakeskeinen oppimisstrategia kehitettiin lääketieteen koulutuksessa jo 1970-luvun puolivälissä (Neufeld \& Barrows 1974; Barrows \& Mitchell 1975), mutta silti se on nähty yhä epätyypillisenä ja jopa haastavana lähestymistapana urheilijoiden valmennuksessa (ks. Trudel, Gilbert \& Werthner 2010; Morgan et al. 2013). Siten myös empiirisiä tutkimuksia ongelmakeskeisen oppimisstrategian käytöstä valmennuksessa on ymmärrettävästi vähän (ks. kuitenkin Hubball \& Robertson 2004; Hubball \& Butler 2006). Silti ongelmakeskeisen oppimistavan on koettu tuottavan hyötyä valmentajien koulutuksessa (Jones \& Turner 2006; Gilbert, Gallimore \& Trudel 2009; Cushion et al. 2010). 
Kolmannen osatutkimuksen aikana herännyt kiinnostuksemme ongelmakeskeistä oppimisstrategiaa kohtaan johtui strategian konstruktivistisista lähtökohdista. Holly Thorpe (2009a; 2009c) peräänkuulutti urheilupsykologisissa tutkimuksissaan vahvaa laji-ideologioiden tuntemusta kaikilta nuorisokulttuuristen lajien parissa työskenteleviltä. Kasvatustieteilijät John R. Savery ja Thomas M. Duffy (1995) painottavat ongelmakeskeisen oppimisstrategian klassikkotutkimuksessaan, että kaikki oppiminen riippuu oppimissisällöstä, oppijan motivaatiosta, asia- ja oppimisyhteydestä sekä oppijan omista päämääristä. Lisäksi oppiminen määräytyy oppimisympäristössä olevasta ja oppimista ohjaavasta herätteestä sekä vuorovaikutteisesta yhteisöstä, jolta oppija saa palautetta ideoihinsa, näkemyksiinsä ja toimimiseensa. (Savery \& Duffy 1995.) Koimme Holly Thorpen kanssa tehdyssä osatutkimuksessa näiden oppimisnäkemysten hierarkiattomuuden ja oppijakeskeisyyden antavan hyvän ja lajikulttuuria kunnioittavan lähtökohdan lumilautailuvalmennukseen.

Kuten oppimispsykologit Cindy Hmelo-Silver ja Catherine Eberbach (2012) kuvaavat, opettajan tehtävänä on olla ongelmakeskeisessä oppimisstrategiassa tiedontarjoajan sijasta oppimisprosessin mahdollistaja ja helpottaja. Näin ollen valmentaja luopuu oppimisprosessissa omasta roolistaan auktoriteettina ja antaa tilaa valmennettavan omalle kekseliäisyydelle, vertaisryhmälle ja oppimisympäristölle. Ongelmakeskeisen oppimisstrategian myötä oppijan tulisi omaksua ja kehittää helposti sovellettavaa tietoa, tehokkaita ongelmanratkaisu-, oppimis- ja yhteistyötaitoja sekä sisäinen motivaatio itsensä kehittämiselle (Hmelo-Silver \& Eberbach 2012). Katsoimme näiden tavoitteiden arvostamisen olevan välttämättömiä valmentajille harrastajalähtöisyyttä ja vapautta kannattavissa nuorisokulttuurisissa lajeissa.

Kun oppimistapahtumat liitetään Saveryn ja Duffyn (1995) mukaan laajempaan kontekstiin, josta oppija on kiinnostunut, ja kun oppijaa autetaan saamaan ote opittavasta kokonaisuudesta ja oppimisprosessista mahdollisimman aidossa ja haastavassa toimintaympäristössä, oppimistulosten pitäisi olla hyviä. Lisäksi oppijaa pitäisi tukea kohti tehokkaita ja itsenäisiä toimintatapoja sekä kohti uskallusta testata osaamistaan ja ideoitaan sosiaalisessa vuorovaikutuksessa myös vastakkaisia näkemyksiä vastaan (emt.) Nämä kaikki näkemykset tukivat mielestämme lumilautailuun jo omaksuttuja oppimismalleja. Koimme, että valmennusmetodien tulisi hyödyntää jo hyväksyttyjä malleja ennemmin kuin yrittää sopeuttaa omaehtoisuutta kannattavaa lajikulttuuria johonkin uuteen.

\subsubsection{Jotain uutta, jotain vanhaa: vertaisvalmennus ja mentorointi}

Galipeaun ja Trudelin (2006) mukaan urheilijat suovat yleensä valmentajalle valtaa oman uransa ohjaamisessa. Samassa tekstissä he kuitenkin mainitsevat, etteivät urheilijat aina arvosta valmentajan tietotaitoa, eivätkä tällöin luota valmentajaan. Lumilautailijoiden harrastajalähtöisyyttä arvostavassa ja nopeasti muuttuvassa alakulttuurissa vertaisten tarjoama tieto kehityksestä, tyyleistä ja tekniikoista voi olla välttämätöntä. Silloin lumilautailijat saattavat luottaa vertaisiin ja mentoreihin valmentajia enemmän. Nämä vertaisryhmät saattavat 
näyttäytyä valmentaja-urheilija-suhteissa ongelmallisina perinteisen urheilututkimuksen kontekstissa (Cushion, Armour \& Jones 2006). Kuitenkin vertaisvalmennuksesta ja mentoroinnista on nähty monia hyötyjä ihmisen urakehitykselle kasvatustieteen, johtamistieteen ja hoitotieteen tutkimuksissa (esim. Bowman \& McCormick 2001; Zwart et al. 2007; Miller 2011). Myös urheilututkimuksissa mentoroinnin hyödyt ovat nousseet esille, vaikkakin vain valmentajan urakehityksen näkökulmasta (Cushion 2006; Jones, Harris \& Miles 2009; Bloom, Stevens \& Wickwire 2003).

Mentoroinnilla tarkoitetaan kehityksellistä prosessia, jossa kokeneempi työntekijä tukee ja avustaa vähemmän kokeneen työntekijän kehittymistä. Mentoroitavat voivat oppia kokeneemmilta ammatin sisältöön liittyviä taitoja ja rooleja sekä saada urakehitystä edistävää suojelua, ystävyyttä ja neuvoja. (Bryant \& Terborg 2008.) Mentoroinnin mahdollistama kriittinen reflektointi on koettu oppijalle tärkeänä. Kuten liikuntasosiologi Criss Cushion (2006) huomaa, arkisten toimintojen keskellä tapahtuva oppiminen luonnollisissa ympäristöissä ja yhteisön jäsenten tukemana opettaa oppijaa syvällisesti. Se myös tutustuttaa oppijaa yhteisön työtavoille.

Eri urheilulajeissa voidaan siis nähdä olevan keskeisiä oppisisältöjä, jotka ovat yhteisö- ja kulttuurisidonnaisia ja siten parhaiten opittavissa mentoreiden ja vertaisten kautta. Nämä taidot voivat puuttua lumilautailuvalmentajilta, varsinkin jos he eivät ole tiukasti mukana lumilautailukulttuurissa (ks. Galipeau \& Trudel 2006).

Kun mentoroinnin idea on kokemukseen perustuvassa hierarkkisessa suhteessa, perustuu vertaisvalmennus tasavertaisten oppijoiden suhteeseen, jossa osapuolet oppivat toisiltaan (Kram \& Isabella 1985). Toimijat ja ryhmät oppivat vuorovaikutuksessa keskenään tarjoten tukea, kumppanuutta, palautetta ja apua (Ladyshewsky 2006). Psykososiaalisen ja ammattiin liittyvän tiedon jakamisen lisäksi vertaiset myös luovat yhdessä uutta, mikä saattaa muodostaa urakehityksen kannalta merkittävän kilpailuedun (Bryant 2005; Bryant \& Terborg 2008). Silti urheilututkijat eivät ole olleet kiinnostuneita tutkimaan vertaisvalmennuksen hyödyntämistä urheilijoiden kanssa työskentelyssä. Aiheen vähäinen kiinnostus valmennustutkimuksessa on mielenkiintoista. Huomasivathan Gareth Irwinin, Sheldon Hantoonin ja David K. Kerwinin (2004) tunnetussa valmentajatutkimuksessaan valmentajien oppivan parhaiten havainnoimalla toisten valmentajien toimintoja ja ottamalla niistä vaikutteita.

\subsection{Lumilautailu ammattina}

Useat markkinointitutkimukset ovat sivunneet nuorisokulttuuristen lajien ammattiurheilua, mutta toistaiseksi olen löytänyt vain sosiologi ja antropologi Gregory J. Snyderin (2012) skeittaustutkimuksen, jossa yhteiskuntatieteellisenä tutkimuskohteena on juuri ammattiurheilu nuorisokulttuurisessa liikkumisessa. Näin ollen olen lähestynyt tutkimuskohdettani olosuhteiden pakosta tuorein viitekehyksin ilman aiempien tutkimusten tukea tai painolasteja. Seuraavassa 
alaluvussa esittelen neljännen osatutkimukseni teoreettisena viitekehyksenä käyttämäni Mikael Lindfeltin huippu-urheilun mallin. Sen jälkeen luon lyhyen teoreettisen katsauksen luoviin toimialoihin, joihin ammattilumilautailun tulkitsen kuuluvan.

\subsubsection{Huippu-urheilun organisoitumisen kolmijako}

Huippu-urheilu tarjoaa helppoa viihdettä urheiluyleisöille, sillä lajien säännöt ovat suhteellisen yksinkertaisia. Siten yleisö ja urheilijat ymmärtävät helposti, kuka voittaa ja ketkä ovat lajien huipulla. Sääntöjensä perustavanlaatuisen samankaltaisuuden vuoksi Mikael Lindfelt $(2007 ; 2010)$ tulkitsee urheilulajit keskenään samankaltaisina. Hannu Itkonen $(2012,165)$ puhuu samasta ilmiöstä urheilun sääntöjen normittamisena siten, "ettei tulkinnalle jää tilaa". Perinteisessä huippu-urheilun rakenteessa, kuten Lindfelt (2007, 29; 2010; 2012) kutsuu kansallisille tavoitteille rakentuvaa urheilujärjestelmän rakennetta, urheilija on ennen muuta osa kansallista urheilujärjestelmää. Tämä järjestelmä osoittaa toimivuutensa silloin, kun se kykenee puskemaan kansallisen tason huippuja mahdollisimman monissa lajeissa kansainvälisen tason huipulle. Silloin kansakunta on onnistunut. Näinhän urheilun kertomukset meille todistavat.

Nykyinen urheilujärjestelmä ei rakennu kokonaisuudessaan perinteiselle huippu-urheilujärjestelmälle; ei edes Suomessa. Osa urheilulajeista houkuttelee näkyvyyttä ja rahoittajia enemmän kuin toiset, ja lajit kilpailevat näistä resursseista keskenään. Monet urheilulajit rakentavatkin taloutensa, organisoitumisensa ja näkyvyytensä kaupallisille toimintatavoille ja mediayhteistyölle. Näiden organisoitumisrakenteiden eriäväisyyksien vuoksi Lindfelt (2007, 50; 2010) jakaa lajit kolmeen kategoriaan: harrastehuippu-urheiluun, yleisöhuippu-urheiluun ja ammattilaishuippu-urheiluun.

Harrastehuippu-urheilun lajeja ylläpidetään kansallisten urheilujärjestöjen tuella. Näiden lajien näkyvyys mediassa on niin pientä, etteivät kaupalliset rahoittajat ole kiinnostuneita rahoittamaan lajien ylläpitoa riittävästi. Urheilijat edustavat kilpailuissa omia maitaan ja kilpailut viestivät eri kansallisuuksien kilpailukyvystä huippu-urheilussa. Lindfelt (2010) puhuukin harrastehuippuurheilun rakentumisesta kansalliselle agendalle, millä hän tarkoittanee pienen mediakiinnostuksen ja yksityisen rahan johdosta urheilijan ja kansallisen urheilujärjestelmän välille syntynyttä keskinäistä riippuvuussuhdetta.

Kansallisen ja kaupallisen organisoitumisen välille piirtyvän janan toisessa äärilaidassa ovat ammattilaishuippu-urheilun lajit, joita ylläpidetään yksityisen rahan ja laajan mediakiinnostuksen voimin. Näiden lajien yhteistyö kansallisten urheiluorganisaatioiden kanssa on ohutta. Kaupalliset toimijat määrittelevät lajien säännöt ja toimintaedellytykset, kuten mediayhtiö ESPN:n järjestämissä lumilautailun X Games -kilpailuissa tapahtuu (Rinehart 2008b). Urheilijoiden kansallisuuksilla ei ole ammattilaishuippu-urheilussa sikäli merkitystä, että median laaja kiinnostus lajeja kohtaan tekee urheilijoista tähtiä heidän taustoistaan riippumatta. Lisäksi lajien rahoitustausta tukee laajaa ammattilaisurheilun järjestelmää, jolloin kansallisten urheiluorganisaatioiden merkitys huippuurheilijoille on taloudellisestikin pieni. Janan ääripäiden väliin jää yleisöhuip- 
pu-urheilu, joka on organisoitunut osittain kansallisin agendoin, mutta joka omaa myös vahvan kaupallisen toimintarakenteen.

Jos Mikael Lindfelt $(2007 ; 2010)$ tarkasteli mallissaan eri lajien sijoittumista kolmeen organisoitumiskategoriaan, niin itse tarkastelin viimeisessä osatutkimuksessani huippulumilautailun eri osa-alueiden asettumista Lindfeltin kehikon sisälle. Tarkoituksenani oli verrata lumilautailua perinteisempiin kilpaurheilulajeihin, jolloin nuorisokulttuurisille lajeille ominaiset organisoitumistavat voivat nousta kiinnostavasti esille. Jos urheilun kenttä on monimuotoistunut kaupallisten toimintatapojen yleistyessä ja urheilulajien medioituessa, tarjoavat nuorisokulttuuriset lajit sääntöjensä ymmärtämiseen yhä lisähaasteita haastamalla kilpaurheiluun nojaavat urheilurakenteet media-areenoilla. Vaikka esimerkiksi X Games -kilpailuorganisaatio on onnistut yksinkertaistamaan ja opettamaan valtavirtayleisöille lumilautailun sääntöjä (2008a; 2008b), ovat huippusuorituksia arvottavat säännöt lumilautailun erikoismedia-areenoilla yhä liian monimutkaiset valtavirtayleisöille. Tai oikeammin: yhteisesti sovittuja sääntöjä ei ole. Nuorisokulttuuristen lajien säännöt rakentuvat erikoismediaareenoilla jatkuville alakulttuurisille neuvotteluille, joihin nojaavat myös lajien harjoittajien hierarkiat (Snyder 2012). Silti nämäkin areenat perustuvat urheilijoiden väliselle kilpailulle, vaikka kilpailu ei ohjaudu valtavirran ymmärtämällä tavalla ja urheiluorganisaation ohjauksessa. Kilpailullisuudesta ja niiden alakulttuurisesta arvostuksesta johtuen sisällytin myös huippulumilautailun media-areenat osaksi huippu-urheilua.

\subsubsection{Ammattilumilautailu luovien toimialojen kontekstissa}

Huippulumilautailun mediavälitteiset areenat eivät asetu säännöiltään kilpaurheilun toimintamalleihin, mutta luovan teollisuuden kanssa niillä on paljon yhteistä. John Hartley (2005a; 2005b) selventää luovan teollisuuden tarkoittavan monialaista kulttuuriteollisuuden osa-aluetta, jossa taiteen perinteet ja mediateknologiaa hyödyntävät teollisuuden tuotantomallit yhdistyvät. Aiemmin luovaa teollisuutta kutsuttiin nimellä kulttuuriteollisuus. Kulttuuriteollisuus korvautui neutraalimmalla luovan teollisuuden käsitteellä kulttuurielitistien varsinkin Frankfurtin koulukuntalaisten - kulttuurille lataaman arvon vuoksi ja tekijänoikeuksien merkityksen kasvaessa (Garnham 2005; Hartley 2005a). Siksi käytän tässä tutkimuksessa luovan teollisuuden käsitettä.

Jatkuvasti muuttuvat tyylit, imagot, musiikit ja muu hienovarainen symboliikka saa näkyvyyttä lumilautailun mediavälitteisillä areenoilla urheilusuoritusten lisäksi. Tämä todistaa Angela McRobbien $(1994,179)$ mukaan kulttuurin vallasta ja nuorisokulttuurisen luovuuden merkittävyydestä sosiaalisessa järjestyksessä. Nuorisokulttuurisissa lajeissa kannatetut yksilöllisyyden, omaehtoisuuden ja tee-se-itse-toiminnan arvot sopivat hyvin uusliberalistisiin ideologioihin, joissa yksilön tulisi ottaa vastuu omasta hyvinvoinnistaan ja aktiivisesta kansalaisuudestaan (Wheaton 2013, 5). Lumilautailun mediavälitteisyyden vuoksi tukeuduin neljännessä osatutkimuksessani John Hartleyn kahteen tutkimukseen, Creative industries (2005a) ja Creative identities (2005b), ymmär- 
tääkseni ammattilumilautailun rahoitusmuotoja, jotka tulkintani mukaan nojaavat kulttuuriteollisuuden voittokulkuun.

Kulttuurisen merkityksenannon kasvaessa yhteiskunnassa on ilmiselvää, että taloudellinen sektori seuraa muutosta. Se sopeutuu kehitykseen ja jopa nopeuttaa sitä. Epäilemättä luovan luokan taloudellista tärkeyttä alleviivaavat tutkimukset ja tutkimuskokoelmat (esim. McRobbie 1994; Ray \& Sayer 1999; Florida 2002; 2005) edesauttoivat kehitystä, jossa luovista toimialoista tuli yhä tärkeämpiä talouspolitiikan kohteita. Taloudellisen taantuman ja internetin kehityksen motivoimat uusliberalistit ovat jakaneet kannustimia luovan teollisuuden kehittämiselle (Hartley 2005a). Tämä kehityskulku on johtanut Nigel Thriftin (1999) mukaan myös organisaatioiden sisäiseen kulttuuriseen käänteeseen, jossa organisaatioiden toimintamalleihin on omaksuttu pehmeää tiedolla johtamista, ja verkostoitumisesta sekä imagon hallinnasta on tullut yhä tärkeämpää.

Hartleyn (2005a; 2005b) näkemykset luovan teollisuuden ja identiteetin poliittisesta tuesta sopivat hyvin ammattilumilautailun kontekstualisointiin. Niiden valossa mediatuotantoihin keskittyvien huippulumilautailijoiden ansaintalogiikka luovuuteen, muunteluun ja tee-se-itse-asenteeseen kannustavassa lumilautakulttuurissa näyttäytyy loogisena. Kulttuurin merkityksen kasvu yhdessä kehitystä vahvistavien poliittisten linjausten kanssa on tuottanut mielikuvaa hyvästä kansalaisesta, jonka tehtävänä olisi olla aktiivisesti luova ja hyödyttää omaksumallaan toimijuusmallilla yhteiskunnan taloudellista toimintavalmiutta (Hartley 2005b). Hartleyn (emt.) näkemysten myötä myös sponsorien halukkuus maksaa näkyvyydestä, luovuudesta ja imagosta asettuu kapitalismin ja interaktiivisen informaatioajan kontekstiin: Tuotteiden tulee tarjota välineitä luovien identiteettien ylläpitoon, mutta sponsorien viesti kuluttajalle hyödykeja informaatiotarjonnan tulvassa voi olla hankalasti välitettävissä. Tähän viestintään lumilautailun mediatuotannot voivat antaa välineen.

\subsection{Lumilautailu sosialisaatioympäristönä}

Viidennessä osatutkimuksessa tarkastelun kohteena oli se, kuinka urheilukulttuureissa ylläpidetyt, tavoitteita koskevat normit ovat muuttuneet nuorisokulttuuristen liikkumismuotojen tullessa keskeisiksi nuorisourheilun sosialisaatioympäristöiksi. Koska hyödynsimme Hannu Itkosen kanssa tehdyssä artikkelissamme sosialisaatioympäristöjen tarkastelukehikkona modernia ja jälkimodernia, käyn lyhyesti läpi sekä sosialisaation että modernin ja jälkimodernin käsitteet.

Sosialisaation käsitteellä on viitattu kasvatustieteissä prosessiin, jossa yhteisön jäsenet omaksuvat yhteisölle ominaista kulttuuria (Antikainen 1992, 75). Tuomas Takalan (1999, 10-12) mukaan sosialisaatiossa on kyse yksilöiden ja yhteisöjen vuorovaikutuksesta, jossa kulttuuristen käytäntöjen siirtämisprosessi takaa yhteisön jatkuvuuden, mutta mahdollistaa myös sosialisaatiopyrkimysten vastustamisen. Emme halunneet ymmärtää sosialisaatiota tutkimuksessamme 
vain omaksumisena tai sen vastustamisena, vaan tukeuduimme Sahlinin ja Wedlinin (2008) tutkimukseen omaksuttujen käytäntöjen valikoimisesta ja muokkaamisesta. Sosiaalistuessaan urheilukulttuureissa ylläpidettyihin tavoitteisiin nuoret oppivat yhteisöön kuulumiseen ja siinä toimimiseen tarvittavia malleja, joita he voivat muokata mahdollisuuksiensa ja urheilukulttuurien normien rajoissa omaan elämäänsä sopiviksi.

Urheilun sosiaalistumisympäristöjen kehittymistä on kuvattu historiallisena prosessina esimodernista jälkimoderniin. Esimodernissa yhteiskunnassa leikit ja kisailut olivat tyypillisiä liikkumisen muotoja, sillä agraariyhteiskunnassa päivittäinen työnteko oli ruumilllista ja kisailemaan ryhdyttiin vain jos voimaa ja aikaa jäi. Kisailemisen tavoitteet olivat yhteisöllisiä. (Itkonen 2012.) Koska kirjoitettuja sääntöjä ei ollut, olivat normit yhteisesti jaettuja perinteitä, joiden noudattamisesta osanottajat neuvottelivat keskenään (Elias \& Dunning 1971, 125-130). Modernisoituessaan urheilulajien sosialisaatioympäristöt muuttuivat yhtenäisten sääntöjen ja tavoitteiden sekä niitä valvovien urheiluorganisaatioiden kehittyttyä (Dunning 1999, 61-64). Esimerkiksi brittiläisissä julkisissa kouluissa suosittu pallon potkiminen muuttui kirjoitettujen sääntöjen ohjaamaksi jalkapalloksi, jossa pelaajilta vaadittiin itsensä kontrolloimista (Dunning 1971, 133-134).

Suomalaisen urheilukulttuurin järjestöihin sidottua normittumista ja sosialisaatioympäristön nopeaa muuttumista kuvaa oivallisesti vuonna 1906 perustetun Suomen Voimistelu ja Urheiluliiton (SVUL) virallinen yleisurheilun ennätysluettelo. Sitä alettiin ylläpitää jo vuonna 1907, vaikka yleisurheilu oli suomalaisille vielä perin uutta. (Kokkonen 2008, 43-44.) Modernin yhteiskunnan ihanteita seuraavaa urheilujärjestelmää jalostettiin koko 1900-luku, mikä näkyy muun muassa lasten ja nuorten urheilun ikäkausiryhmien ja kilpailusarjojen kehittymisessä 1900-luvun puolivälistä eteenpäin (Itkonen 2003, 331-334). Moderni urheilujärjestemä kannusti myös erikoistumiseen, mikä kasvatti lajiliittojen määrää 1900-luvun loppuun asti (ks. Koski \& Heikkala 1998, 63).

Nuorisokulttuuriset lajit poikkeavat kontrollin ja rationaalisuuden suuntaan kehittyneistä urheilujärjestelmistä. Liikuntatieteilijä Gunnar Breivik (2010) osoittaa nuorisokulttuuristen lajien harrastajien arvostavan jälkimoderniin aikaan sopivasti riskejä, yksilöllisiä kokemuksia ja valinnnanmahdollisuuksia enemmän kuin mitä moderni urheilujärjestelmä sallii osanottajilleen. Belinda Wheaton $(2004,11-12)$ taas tulkitsee nuorisokulttuurisen liikkumisen hauskuuden, hetkessä elämisen ja nautintokeskeisyyden haastavan vanhan urheiluperinteen. Hän kuitenkin haluaa sanoutua irti modernin ja jälkimodernin käsitteistä toteamalla uudenlaisten kuluttaja-aktiviteettien ja vapaa-aikateollisuuden nousseen hyvin keskeisiksi nykyajan kapitalistisessa taloudessa (emt., 6-7). Wheaton $(2013,5)$ osoittaa nuorisokulttuurisen liikkumisen piirteistä mieluummin uusliberalismin kulttuurisia ja ekonomisia vaikutuksia kuin jälkimodernin ajan aatemaailmaa. Tarkempaa syytä valinnalleen hän ei esitä.

Varsinkin brittiläisessä liikuntasosiologisessa tutkimusperinteessä modernin urheilujärjestelmän kehittyminen on liitetty hyvin vahvasti yhteiskuntien kulttuuriseen kehittymiseen. Tässä moderni tarkoittaa valistuksen hengessä 
kehittynyttä sivistyksen arvostusta ja oikeusperiaatteen toteutumista sääntöjen kehittymisen vuoksi (ks. Dunning 1971; 1999; Elias \& Dunning 1971). Näissä tutkimuksissa on siis korostunut yhteiskunnallisen kehityksen kulttuurinen puoli tuotantotaloudellisen sijasta, vaikka aineellisten olosuhteiden kehittymiseenkin on usein viitattu (ks. esim. Itkonen 2003; 2012). Tähän kulttuuristen käytäntöjen korostamisen perinteeseen asettuu myös lumilautailua tarkasteleva Riitta Hännisen (2012) antropologinen väitöskirja, joka hyödyntää myöhäismoderneja alakulttuuriteorioita.

Viidennessä artikkelissa päätimme jatkaa kulttuuristen liikuntasosiologisten tutkimusten perinnettä ja hyödyntää näkemystä modernin ja jälkimodernin urheilun normatiivisista eroista. Halusimme tarkastella, miltä nuorisokulttuuriset liikkumismuodot näyttävät niiden tutkimusten rinnalla, jotka kokevat urheilulajien kehityksen valistuksen perinteen seurauksena. Emme ota kantaa keskusteluun myöhäismodernista, jälkimodernista tai notkeasta modernista (ks. esim. Mouzelis 2008), joskin valitsemamme koonnit jälkimodernin ajan aatteista antavat tunnustusta myös niin kutsutun postmodernismin näkemyksille. Kuitenkin esimerkiksi Stephen Waggin ja kumppaneiden $(2009,174-180)$ liikuntasosiologisesta käsiteselvityksestä huomaa, kuinka hankalaa jälkimodernin ajan ja postmodernistien aatteita on erottaa toisistaan - vakaasta yrityksesta huolimatta. Viittasimme jälkimodernin ajan käsitteellä niihin aatteisiin, joilla nykyaikana haastetaan modernille ajalle ominaisia piirteitä. Aatteilla tarkoitimme ihmisten suhtautumista ympäröivään maailmaan, eli viimeisessä osatutkimuksessa urheilukulttuurien tavoitteisiin. Toisin sanoen, paikansimme tutkimuksessamme sitä tavoitteita koskevien normien muutosta, mikä uusissa urheilukulttuuriessa näkyy vanhempiin urheilukulttuureihin verrattuna.

Hyödynsimme Steven Seidmanin (1994) ja Pushkala Prasadin (2005, 221237) koonteja jälkimodernin ajan piirteistä. Seidman (1994, 2-4) ja Prasad (2005, 219-220) kuvaavat yhtäältä rajojen populaarikulttuurin ja taiteen välillä sekä toisaalta niiden sisäisten tyylisuuntien välillä hämärtyneen. Samalla totisuuteen ja elitismiin pyrkiminen on haastettu hauskanpidolla ja ironialla. Lisäksi Seidman $(1999,2)$ kertoo modernia aikaa leimanneen yhteiskunnallisen eriytymisen muuttuneen monelta osin yhteiskunnan osasten sekoittumiseksi. Tulkitsimme tämän tarkoittavan tutkimuksemme kontekstissa esimerkiksi sitä, että urheilun ja median käytännöt ovat sekoittuneet nuorten hahmottaessa urheilusuorituksiaan mediatallenteiden avustuksella, kun he kuvaavat suorituksiaan ja levittävät tallenteita sosiaalisen median kautta yleisöille (ks. Woermann 2012).

Lumilautailun tarkasteleminen jälkimoderniin peilaten on sikäli perusteltua, että Duncan Humphreys (1996; 2003) on osoittanut lumilautailun kehittyneen saman 1960-luvun vapaa-aikaliikkeen ilmapiirin seurauksena, jonka sosiaalihistorioitsija Hans van Zon (2013) esittää jälkimodernien aatteiden henkisenä kotina. Vapaa-aikaliike ihannoi uudenlaista yksilöllisyyttä ja kehotti ihmisiä löytämään oman elämäntyylinsä, minkä avulla tavoiteltiin erontekoja totisesta ja mukautumiseen kannustavasta yhteiskunnasta. Sama yksilöllisen elämäntyylin arvostaminen mahdollisti Zonin (emt.) mukaan myös uusliberalismin voittokulun. Tässä tulkintakehikossa lumilautailu asettuu sosiaalistumisympäristö- 
nä niihin alakulttuurisiin yhteisöllisyyden muotoihin, jotka ovat syntyneet Jaana Lähteenmaan $(1991,262)$ näkemyksen mukaan modernisoitumisen vastareaktiona. Lähteenmaan (emt.) tulkinta skeittareiden yhteisöllisyydestä eriytyneen modernin yhteiskunnan vastustuksena on kuitenkin epälooginen, ellei tulkitse vapaa-aikaliikkeen kannattaman yksilöllisyyden antaneen lupaa olla yksilöllisesti yhteisöllinen valtavirrasta poikkeavalla tavalla.

Omassa tutkimuksessani tarkastelen lumilautailun sosiaalistumisympäristöä väljempänä ilmiönä kuin Lähteenmaa (1991) elämäntapaskeittareita. Vaikka viittaan toisinaan lumilautailun alakulttuurisuuteen, näen lajin sisälle mahtuvan samaan aikaan sekä valtavirtaisuutta että alakulttuurisuutta. Tässä suhteellisen epäyhtenäisessä lajikulttuurissa lumilautailijat sekä omaksuvat lajissa ylläpidettyjä kulttuurisia käytäntöjä että vastustavat ja kehittävät niitä lajin sisällä. Samalla lumilautailijat reagoivat emo- ja valtakulttuureiden käytäntöihin toisinaan vastustaen ja toisinaan hyväksyen. 


\section{TUTKIMUSPROSESSI JA TUTKIMUKSEN RAKENTUMINEN}

Väitöskirjatyö on mahdollista tehdä monografia- tai artikkelimuotoisesti. Nuorisokulttuuristen lajien muutostahdin nopeus, jonka Holly Thorpe ja Belinda Wheaton (2011) kuvaavat haastavaksi urheiluorganisaatioille, kannusti minua tarttumaan osajulkaisumuotoiseen väitöskirjaan. Artikkeleissa tutkimusaiheet, aineistot ja teoreettinen viitekehys elävät tutkimusprosessin mukana joustavammin kuin monografiassa (Valo 2013). Seuraavaksi esitän oleelliset asiat osatutkimusten ympärille rakentuvan väitöskirjani aineistonkeruuprosessista. Sen jälkeen tarkastelen osatutkimus kerrallaan jokaiseen alaongelmaan liittynyttä tutkimusprosessia ja tutkimuskysymyksiä. Viimeiseksi kuvaan lyhyesti sen tiedonkäsityksen, jolle koko tutkimukseni oleellisesti perustuu.

\subsection{Tutkimuksen lähtökohdat ja perusaineiston kertyminen}

Halusin ottaa tutkimusprosessissa alusta alkaen huomioon lumilautailijoiden intressit. Siten merkitysten tutkiminen tuli tutkimuksen kantavaksi teemaksi, vaikken osatutkimuksissa liiemmin merkityksen käsitteen kanssa ole operoinutkaan. Kuitenkin samalla tavalla kuin filosofi Jonathan Lear $(2006,48)$ kuvailee kirjassaan shakkinappuloiden maailmaa laudalla, jossa tietyt säännönmukaisuudet, perinteet, roolit ja tavoitteet antavat nappuloille ja siirroille merkityksiä osana laajempaa kontekstia, olen pyrkinyt tarkastelemaan ammattilumilautailun kentän toimijoita ja instituutioita siitä suunnasta, mihin kontekstiin ne asettuvat lumilautailijoiden näkeminä heidän urallaan. Näin ollen laadullinen menetelmä oli tutkimuksessani luonnollinen valinta (Denzin 2007).

Suunnittelin tutkimusprosessin alussa toteuttavani tutkimukseni etnografista menetelmää hyödyntäen, joskin myös puolistrukturoituja haastatteluja tehden. Vaikka etnografista tutkimusta voi tehdä monella syvyystasolla (Wolcott 1988, 202), ajattelin etnografian olevan välttämätön metodi valaistaessa lumilautailijoiden tapaa hahmottaa uraansa. Pian kuitenkin huomasin, ettei taus- 
tani lumilautailua pitkään harrastaneena aktiivina ja entisen ammattilumilautailijan vaimona ollutkaan etnografisen lähestymistavan kannalta pelkästään positiivinen seikka. Jos Bronislaw Malinowski (esim. 2005 [1922]) saattoi tehdä kenttätyönsä ja poistua saarelta analysoimaan "villi-ihmisistä" tekemiään havaintoja, tunsin eläväni keskellä villiä lumilautakenttää koko ajan. Joka päivä toi mukanaan lisää havaintoja, sillä havainnoitavat osallistujat olivat tuttujani. Näin ollen etäisyyden ottaminen aineistosta, minkä Machteld de Jong, Frans Kamsteeg ja Sierk Ybema (2013) mainitsevat metoditutkimuksessaan keskeiseksi etnografisen prosessin osaksi, oli mahdotonta. Sen vuoksi päädyin suosimaan pelkästään puolistrukturoitua haastattelua tutkimuksen aineistonkeruussa, joskin kolmannessa osatutkimuksessa aineistoksi valikoituivat aiemmat tutkimukset.

Puolistrukturoitujen haastattelujen suosimiseen kehotti myös ensimmäisen artikkelini toinen vertaisarvioija. Hän koki etnografisen asetelman selittämisen artikkelin metodiosuudessa hankalaksi. Vertaisarvioijan kehotuksesta vakuutuin siitä, että keräämäni haastatteluaineisto oli täysin riittävä ensimmäisessä osatutkimuksessa tekemieni löydösten pohjaksi. Näin kenttäjaksojen havaintojen analysointi jäi pois osatutkimuksista ja keskityin pelkästään haastatteluaineistoon. Tämä poukkoilu ei kuitenkaan näy artikkelien aineisto-osuuksista, kuten lineaariseen tutkimusprosessikuvaukseen pyrkivissä tutkimusraporteissa on Cathrene Marshallin ja Gretchen B. Rossmanin $(2006,23)$ mukaan tyypillistä.

Puolistrukturoituja haastatteluja suunnitellessani ja tehdessäni nojauduin ennen muuta John Amisin (2005) ohjeisiin haastattelututkimuksen tekemisestä urheilututkimuksessa. Olin tietoinen joidenkin metoditutkijoiden varoittelevasta suhtautumisesta sellaista haastatteluasetelmaa kohtaan, jossa haastattelijan rooli tiedon tuottajana on keskeinen, kuten puolistrukturoiduissa haastatteluissa nähdään olevan. Esimerkiksi Michael Quinn Patton $(2002,347)$ kokee puolistrukturoidun haastattelun strukturoitua hankalampana, sillä haastattelurungon väljyys saattaa aiheuttaa sen, että joltain osallistujalta kerätään enemmän tietoa kuin toiselta. Olin kuitenkin vakuuttunut siitä, että puolistrukturoidun haastattelun joustavuus sopii lumilautailijoille ominaiseen rentouteen. Päätin noudattaa niitä metoditutkijoita, jotka painottavat laadullisen tutkimuksen vahvuuksina joustavuutta, mukanaelämistä ja herkkyyttä muuttuville tilanteille (Marshall \& Rossman 2006, 138). Esimerkiksi kielen muuttaminen kuhunkin tilanteeseen ja kullekin informantille sopivaksi vaikutti lumilautailijoiden kanssa hyvältä ratkaisulta.

Tutkimukselleni ongelmallisimpana valintana koen sen, että lähdin kentälle tekemään haastatteluja kovin varhain. Ensimmäisen tutkimussuunnitelman laadin elokuussa 2010 ja lokakuun lopussa olin jo tekemässä haastatteluja. Koin tämän järjestelyn kuitenkin resurssien vuoksi välttämättömänä. Helsingin messukeskuksessa vuosittain pyhäinpäivän viikonloppuna järjestettävät Skiexpo -messut keräävät yhteen suomalaiset ammattilumilautailijat ja puoliammattilaiset. Messuilla lumilautailijat ovat varautuneita siihen, että he ovat median ja markkinoinnin käytettävissä. Ajattelin tämän ympäristön olevan sopiva tutkimukseni aineistonkeruulle. Päätin siis tavoitella haastateltavien ja haastattelu- 
paikan valitsemisessa John Amisin (2005) ohjeen mukaisesti realismia ja valita sellaisen paikan ja osanottajat, jotka olisi mahdollista saavuttaa.

Skiexpo -messujen valikoitumiseen haastattelupaikaksi vaikutti myös se seikka, että tein tutkimustani vielä tuossa vaiheessa Kansaneläkelaitoksen tarjoamien tukien turvin. Jos en olisi valinnut Skiexpo-messuja vuonna 2010 kenttätyöpaikaksi, olisivat informantit olleet taas ympäri maailmaa kiireisen kilpailuja kuvauskalenterinsa vuoksi ainakin kesään asti. Kesällä taas aineiston keruu olisi vaatinut vankempia resursseja, jotta olisin kyennyt matkustamaan informanttien perässä heille sopiviin haastattelupaikkoihin.

En ollut Skiexpo-messuista huolimatta täysin vakuuttunut siitä, että informantit olisivat valmiita käyttämään tunnin kiireisestä messuajastaan kysymyksiini vastaten. Siksi sovin Snow Extreme -lehden päätoimittajan kanssa tekeväni lumilautailijan työtä koskevan jutun lehteen. Tällöin näkyvyydestä kiinnostuneet lumilautailijat saattavat motivoitua löytämään haastatteluaikaa herkemmin. Haastatteluaineiston keräämiseksi tehty yhteistyö lehtien kanssa vaikutti niin toimivalta, että tein kaiken kaikkiaan viisi juttua haastatteluaineistoon liittyen sekä Snow Extreme että Slammer -lehdille. Haastatellut lumilautailijat antoivat luvan haastatteluaineiston käyttöön sekä tutkimus- että mediatarkoituksissa. Koska lumilautailijat ovat tottuneita tekemään yhteistyötä lumilautamedian kanssa, koin haastatteluiden kannalta jopa hyvänä, että haastateltavat yhdistivät haastattelutilanteen itselleen tuttuun kontekstiin. Sain itse päättää lehtijuttujen aiheista, minkä vuoksi saatoin toimia oman haastattelurunkoni puitteissa. Samoin saatoin kattaa lehtijutuista saamillani pienillä tuotoilla aineistonkeruuvaiheesta aiheutuneita kuluja.

Skiexpo-messut vuonna 2010 osoittautuivat hyväksi paikaksi tavoittaa haastateltavia. Noudatin informanttien valinnassa niin kutsuttua lumipallometodia (Patton 2002, 237; Amis 2005): edellinen haastateltava antoi vinkin seuraavasta informantista, jolla voisi olla hyvä näkemys suomalaisen lumilautailijan uraan. Lumipallometodiin liittyvänä käytäntönä oli kysyä suomalaisilta ammattilumilautailijoilta: "Kuka tietäisi paljon suomalaisen ammattilumilautailijan urasta lumilautailijan suunnasta?" (Patton 2002, 237). Lisäksi pyysin jokaista haastateltua ammattilumilautailijaa nimeämään Skiexpo-messuilla kolme mahdollista puoliammattilaista, jotka tulevat "breikkaamaan läpi lähivuosien aikana". Pyrin tavoittamaan aineistonkeruuaikana ainakin viisi ammattilaisten mainitsemaa tulevaisuuden lupausta. Näillä valinnoilla koin tavoittavani mahdollisesti sellaisia informantteja, joilla on laadullisessa tutkimuksessa tavoiteltavaa rikasta tietoa (Marshall 1996) ammattilaisuuteen kiinnittymisestä lumilautailijan näkökulmasta.

Olin kuitenkin varautunut haastattelemaan vain lumilautailijoita messuilla, mikä oli virhe. Muistin vasta messujen aikana, että messukojuilla työskentelee paljon lumilautamedian, sponsorien ja lumilautaliiton henkilökuntaa. Heillä on kaikilla paljon näkemyksiä suomalaisen lumilautailijan urasta. Epäilemättä suomalaisen lumilautailijan kiinnittymisessä ammattilaisuuteen vaikuttaa yhteistyö sponsorien, median ja urheiluorganisaatioidenkin kanssa. Messujen aikana päätin laajentaa tutkimusasetelmaani niin, että astun jossakin tutkimus- 
prosessin vaiheessa myös lumilautailijan näkökulman ulkopuolelle. Tämä katsantokannan laajennus tapahtui toisessa ja neljännessä osatutkimuksessa.

Skiexpo-messut ja lumipallometodi toivat eteeni myös tiedon uusista kenttäjaksoista. Kuulin lumilautailijoiden suuntaavan Skiexpon jälkeen Rukan ensilumille epäviralliselle maajoukkueleirille. Pakkasimme messumatkan jälkeen perheen tavarat autoon ja kutsuimme itsemme appivanhempieni seuraksi syyslomamatkalle Rukalle. Lisäksi matkustin vielä Tahkolle Finnish Open kilpailuihin huhtikuussa 2011, Rukan Wappulounas -tapahtumaan vappuna 2011, Skiexpo-messuille pyhäinpäivänä 2011 ja Oslon maailmanmestaruuskilpailuihin helmikuussa 2012. Vuoden 2011 alussa Jyväskylän yliopiston rehtorin apurahoista ja vuodesta 2012 eteenpäin opetus- ja kulttuuriministeriöltä järjestyneet tutkimusrahoitukset mahdollistivat myös aineistonkeruumatkat Kelan tukia paremmin.

Tein kenttämatkojen lisäksi kaksi haastattelua puhelimitse ja yhden sähköpostitse informanttien toiveesta ja pitkien välimatkojen vuoksi. Puhelimitse haastattelemisen koin hankalaksi, sillä sovitut soittoajat eivät käyneetkään informanteille ja kuuluvuutta ei aina ollut. Sähköposti aiheutti silti enemmän päänvaivaa, sillä jouduin kerjäämään vastauksia useaan otteeseen ja sain silti vastaukset vain osaan kysymyksistä. Tein myös yhden haastattelun Jyväskylässä ja kaksi haastattelumatkaa Helsinkiin tavoittaakseni edellisten haastateltavien suosittelemia informantteja. Helsingin-matkat koin turhauttaviksi siksi, että tapaamiset olivat vähemmän spontaaneja ja haastattelutilanteet sen vuoksi selvästi varautuneempia kuin lumilautailutapahtumissa. Lisäksi yhden haastattelumatkan tein Helsinkiin turhaan, sillä haastateltava ei ilmaantunutkaan sovittuun tapaamiseen.

Lumilautailijoiden haastattelurunko rakentui kuuden teeman ympärille: lumilautailemisen taustat; harrastuksen muuttuminen vakavammaksi; kiinnittyminen ammattilaisuuteen; työnkuva; ammattilaisuuden aiheuttamat paineet; lumilautailu- ja urataitojen oppiminen. Teemojen alle olin rakentanut kahdesta kuuteen valmista kysymystä (liite 1), joiden käsittelyn pyrin varmistamaan haastatteluiden aikana, kuten puolistrukturoiduissa haastatteluissa on tapana (Amis 2005). Kysymykset olin rakentanut selvittämään kutakin teemaa kentän toimintatapojen ja rahoituksellisten seikkojen hahmottamisen kannalta. Kysymysten järjestys ja sanavalinnat vaihtelivat tilanteen mukaan. Keskustelu myös rönsyili uusiin kysymyksiin ja aiheisiin, jotka osoittautuivat mielenkiintoisiksi haastattelun aikana; vaikka pääsääntöisesti pyrin pysymään rungon sisällä, kuten Patton $(2002,344)$ kehottaa. Lisäksi keskityin kolmen Yhdysvalloissa asuvan lumilautailijan kanssa enemmän lumilautailijan uraa koskeviin Euroopan ja Pohjois-Amerikan eroihin. Näitä teemoja en saanut muilta haastateltavilta omakohtaisina esiin, ja kuitenkin Pohjois-Amerikka näyttäytyi jo kerätyssä aineistossa merkittävänä markkina-alueena myös lumilautailijan uran kannalta.

Tutkimuskysymysten rakentamiseen olisin voinut käyttää selvästi enemmän aikaa ja harkintaa. Olin toki tietoinen erilaisista kysymystyypeistä (Patton 2002, 348-352), mutta tavoitteet kentän toimintatapojen ja rahoituksellisten seikkojen selvittämiseksi eivät ehkä realisoituneet tieteellisesti hienostuneim- 
malla tavalla. Myöskään metodioppaat eivät tarjonneet selkeää ohjeistusta siihen, millä perusteella juuri tiettyjen kysymysten tulisi valikoitua kysymysrunkoon. Koin myöhemmin, että vahvempi teoreettinen lähestymistapa olisi helpottanut myös haastattelurungon rakentamisessa. Tutkimuksen alkuvaiheessa luin toki paljon nuorisokulttuuriseen liikkumiseen ja alakulttuurin teorioihin liittyvää kirjallisuutta, mutta haastattelurungon rakentaminen näiden tutkimusten pohjalta jäi mielestäni lopulta turhan irtonaiseksi. Sosiologi Toni Brucen (2010) mukaan teoreettisen kehikon irtonaisuus on väitöskirjatasoisille tutkimuksille hyvin yleistä.

Vaikka puolistrukturoitu haastattelu joustaa kysymysten sanamuodoissa ja järjestyksissä, koin suunniteltujen kysymysten kysymisen toisinaan turhauttavana. Kysyin esimerkiksi yhdeltä informantilta haastattelurungon kolmanteen teemaan liittyvän kysymyksen ensimmäisten sponsorisopimusten saamisesta, vaikka tiesimme informantin kanssa molemmat, että oma aviomieheni oli auttanut järjestämään sopimuksen kyseiselle informantille jokunen vuosi aikaisemmin. Toisen informantin kanssa olin elänyt samaa arkea jossain vaiheessa niin tiiviisti, että ymmärsin vasta haastattelun aikana olevani itsekin osa informantille merkittävää urakertomusta. Samoin jouduin leikkimään tietämätöntä asioissa, jotka kuvittelin tietäväni varsin hyvin. Yhdessä haastattelussa tämä näytteleminen aiheutti jopa närkästystä haastateltavassa. Näin ollen koin useita sellaisia tilanteita, joita Robert R. Faulkner ja Howard S. Becker (2008) mainitsevat tyypillisiksi haastateltaessa tutkijalle tuttuja ihmisiä ja ilmiöitä. Tuttuuden aiheuttamissa tilanteissa koin apua sen tiedostamisesta, etten tutki faktatietoja vaan lumilautailijoiden havaintoja ja kokemuksia, jotka ilmentävät heidän omia tapojaan jäsentää kulttuuria (Alastalo \& Åkerman 2010). Samalla kuitenkin koin showpainia tutkineiden Ted M. Butrynin ja Larry deGarrisin (2008) tavoin, että osallistuminen ja pyrkimys aktiiviseen mukanaoloon vaikuttavat positiivisesti siihen, millaista tietoa minun oli mahdollista saada käsiini. Haastateltavat yrittivät auttaa minua oman työni tekemisessä jopa siinä määrin, että sain hyviä vinkkejä sovinnaisista kirjoitustyyleistä lumilautailulehtien juttuja varten. Huomasin silti haastatteluaineistoa litteroidessani, että olisin voinut olla vieläkin tietämättömämpi, jotta jotkut sanomattomat seikat olisivat päätyneet nauhalle.

Tutkimusaineistoon kertyi lopulta 19 mieslumilautailijan ja 2 naislumilautailijan haastattelut, joista 16 oli haastatteluaikaan ammattilaisia ja 5 puoliammattilaisia. Informanttien kotipaikka jakautui läpi Suomen, joskin kolme informanttia asui pysyvästi Yhdysvalloissa. Iältään informantit olivat 17-31vuotiaita. Haastatteluista kolme toteutettiin samanaikaisesti kahden toisensa hyvin tuntevan informantin kanssa. Poistin myös aineistosta kaksi haastattelua, koska niissä ei koskaan päästy käsiksi kysymyksiin, jotka muodostuivat keskeisiksi osatutkimusten aiheille.

Lumilautailijoiden lisäksi haastattelin tutkimustani varten neljää lumilautailijoiden henkilökohtaista manageria, joille tein kysymykset lumilautailijan urataustan, ammattilaisuuteen kiinnittymisen ja työnkuvan teemoihin liittyen. Viideltä sponsorien team managerilta taas kysyin kysymyksiä lumilautailijan 
ammattilaisuuteen kiinnittymisestä ja työnkuvasta. Kaikki managerit ja team managerit olivat kansainvälisen tason toimijoita. Kaikki managerit olivat suomalaisia, mutta yksi heistä asui Ranskassa. Sponsorien team managereista neljä oli ulkomaalaisia, minkä vuoksi nämä haastattelut toteutettiin englanniksi. Teemoihin liittyvät kysymykset sopeutettiin managereille ja sponsorien team managereille sopiviksi, kuten puolistrukturoiduissa haastatteluissa on tapana (Amis 2005). Sopeuttaminen tarkoitti tässä tilanteessa hyvin luovaa soveltamista: Tapasin yleensä näitä managereita niin yllättävissä tilanteissa, ettei minulla ollut kyseiselle informantille sopivia haastattelukysymyksiä valmiina tai mukana. Jos yritin sopia tapaamista erikseen jonnekin, olivat varsinkin ulkomaiset informantit niin kiireisiä, ettei heitä kyennyt tavoittamaan lopulta haastatteluun edes lumilautailijan pyynnön jälkeen. Siksi koin riittäväksi, että sain haastattelut tehtyä jossakin spontaanissa tilanteessa, vaikka puhelimeen nauhoittamalla. Muistelin kysymysrunkoa sekä noudatin teemoja, jotka olin painanut mieleeni. Lisäksi haastattelin kolmea suomalaista lumilautamedian edustajaa, kahta valmentajaa ja kahta maahantuojaa, mutta näitä haastatteluja en käyttänyt aineistona mihinkään osatutkimukseen.

Litteroin kaikki haastattelut analyysiä varten. Yhteensä litteroitavaa nauhurimateriaalia oli pitkälle toista tuhatta minuuttia. Lyhin haastattelu kesti vain noin kymmenen minuuttia, kun taas pisin oli hieman yli tunnin mittainen. Lyhimmät haastattelut olivat kiireisten maahantuojien, managerien ja team managerien kanssa tehtyjä. Lumilautailijoiden haastattelut kestivät pääsääntöisesti 30-60 minuuttia. Kaksi haastatteluista kesti vain noin vartin ja kaksi 60-75 minuuttia. Aineiston litterointi oli puuduttava, mutta välttämätön keino etäännyttää itseään kentän tapahtumista siten, että ainestosta sai muodostettua analysoitavan kokonaisuuden. Pyrin silti valitsemani tietoteoreettisen näkökulman vuoksi säilyttämään läheisen suhteen aineistoon, mistä kerron lisää alaluvussa 3.7. Samalla kirjoittelin varovasti mielenkiintoisia huomioita aineistosta. Vaikka kaikki huomiot eivät osoittautuneet lopulta merkittäviksi artikkeleiden kannalta, auttoi huomioiden kirjoittaminen hahmottamaan aineiston sisältöä ja kokonaisuutta.

Oslon-matkan (2012) jälkeen olin niin aineistopöllyssä, että analysoimista varten tarvittavan etäisyyden ottaminen aineistoon tuntui hankalalta. Haastattelumetodeista kirjoittaneet Johanna Ruusuvuori, Pirjo Nikander ja Matti Hyvärinen (2010) ovat varoitelleet aineiston aiheuttamasta hämmennyksestä. Aineistoa oli kertynyt hyvin, mutta sen sisällön hahmottaminen oli vielä mahdotonta. Tässä kohdassa päätin tietoisesti, että aineiston keruu on ohi ja aineisto saa riittää.

Olin kirjoitellut ensimmäistä artikkelia jo ilman Oslossa keräämääni aineistoa. Aineiston kylläisyystasoa en kuitenkaan pystynyt arvioimaan. Tämänkaltaisille tutkimusprosesseille on tyypillistä, ettei tutkija ole vielä aineiston kerättyään täysin tietoinen siitä, mitä kaikkea tulee aineistostaan etsimään, ja millaisiin osatutkimuksiin tulee aineistoaan käyttämään (Eskola \& Suoranta 2003). Saturaatiota tutkineiden teoreetikoiden (Guest, Bunce \& Johnson 2006) mukaan aineistoni koko viittasi kuitenkin kylläisyyteen. Lisäksi totesin, että aineistoni 
koko oli määrällisestikin mitattuna hyvä, sillä Suomen Lumilautaliiton toiminnanjohtaja Mats Lindfors (henkilökohtainen tiedonanto, 12.8.2010) arvioi vuonna 2010 suomalaisia ammattilumilautailijoita olleen (kyseisenä vuonna) 20-30 ja niin ollen olin haastatellut tästä joukosta yli puolet. Tässä vaiheessa ohjaajani kehotti tutustumaan Seppo Knuuttilan (2010) tekstiin tutkimusaineistojen muodostamisesta.

Knuuttila $(2010,21)$ kirjoittaa tutkijan tilanteesta, jossa kaikki näyttää merkitykselliseltä ennen "kitkennän, harventamisen, preparoinnin, purkamisen, uudelleen kasaamisen ja muiden aineiston muokkausoperaatioiden aloittamista". Aloitin aineistoon tutustumisen ja muokkaamisen omassa tutkimuksessani sillä, että päätin sulkea silmät kaikesta ympärillä tapahtuvasta voidakseni alkaa muodostaa aineistosta analysoitavaa kokonaisuutta. Analysoitavan kokonaisuuden muodostaminen haastatteluaineistostani oli hankalampaa kuin olin tutkimuskentälle lähtiessäni suunnitellut. Vaikka lumilautailutapahtumissa tapahtunut aineistonkeruu osoittautui taloudelliseksi ja informantit olivat myötämielisiä haastatteluille, eivät haastatteluolosuhteet aina tukeneet suunnitelmieni mukaista haastattelun läpivientiä. Esimerkiksi yksi haastattelu sovittiin tehtäväksi päiväsaikaan, mutta informantti oli niin kiireinen, että tapaaminen lykkääntyi. Odottelin koko päivän soittoa. Informantti halusi kuitenkin pitää kiinni sovitusta tapaamisesta, joka lopulta järjestyikin lumilautailuelokuvan ensiiltatapahtumaan, Helsingin keskustan yökerhoon. Ensin neuvottelin tapahtuman ovimiehen kanssa oikeudesta ottaa haastattelulaitteeni sisätiloihin, ja sen jälkeen etsimme informantin kanssa haastatteluun soveltuvan tilan. Löysimme yökerhossa sijainneen kabinetin, josta saimme lopulta häädön haastattelun puolessa välissä. Muut tilat olivat liian meluisia haastattelemiselle, joten haastattelu oli ohi. Olen haastatellut myös messuhalliin tuodun VIP-bussin ohjaamossa jakaen penkin kontrabasson kanssa samalla, kun jumittuneet pyyhkijät lyövät tahtia keskustelullemme. Olen myös ilmoittanut haastateltavalle haastattelun kestävän noin tunnin, mutta puolessa välissä kavereilta tullut soitto ja kyyti rinteeseen jättää haastattelumme kesken. Nämä olivat vain muutamia esimerkkejä niistä tilanteista, jotka tekivät haastatteluaineistosta kovin repaleisen. Näin en voinut toteuttaa Irving Seidmanin (2006, 20, käännös A.-L. O.) metodioppaassaan antamaa neuvoa haastattelujen kestosta: "On tärkeää, että haastattelujen kestoaika päätetään ennen kuin haastatteluprosessi alkaa."

Jos selvisimme haastattelutilanteessa loppuvaiheisiin, tuli informanttien kyllästyminen usein vastaan noin 45 minuutin kohdalla, mikä näkyy haastateltavien tiedusteluina kysymysten määrästä. Huomasin kuitenkin informanttien olleen hyvin suopeita haastatteluiden tekemiselle, mikä saattaa johtua yhteistyöstäni lumilautailumedian kanssa, sekä tietysti siitä, että monet informanteista olivat tuttujani useiden vuosien takaa. Tuttujeni haastatteleminen oli tutkimuskentän tuttuuden vuoksi välttämätöntä. Tämän vuoksi jouduin vain toteamaan, että metoditutkijat (Seidman 2006, 42; Faulkner \& Becker 2008) löytävät tuttujen haastattelemisesta sekä negatiivisia että positiivisia puolia.

Näistä haastatteluista muodostui tutkimuksen perusaineisto. Toista ja kolmatta artikkelia varten keräsin lisäaineistoa, kuten seuraavissa alaluvuissa 
tarkemmin selvitän. Perusaineiston repaleisuus vaikutti tutkimuksen kulkuun siten, että osaongelmien valitsemisvaiheessa tiedostin Pattonin $(2002,349)$ mainitsemat puolistrukturoidun haastattelun heikkoudet ja tarkistin, että jokaisessa osatutkimukseen valikoituneessa haastattelussa myös käsiteltiin kyseistä aihetta.

Siirtyminen etnografisesta otteesta kohti haastattelututkimusta osoittautui toimivaksi ratkaisuksi. Koin pystyväni vastaamaan asettamiini tutkimuskysymyksiin paremmin ottamalla välimatkaa tutkimuskohteeseeni. Oma tutkijapositioni säilyi silti suhteellisen lähellä kenttää. Vaikka etnografinen ote jäi tutkimuksessa taka-alalle ja suljin arkistoni mielenkiintoisilta tapahtumilta Oslon maailmanmestaruuskilpailuiden jälkeen, ei arjessa tapahtunut kenttätyö todellisuudessa loppunut. Olisi epärehellistä väittää, ettei oma suhteeni kenttään olisi vaikuttanut niihin tulkintoihin, joita tutkimuksessani tein. Vaikka pyrin analysoimaan tiukasti haastatteluaineistoa, huomasin helposti ne aineiston säännönmukaisuudet, jotka olivat minulle tuttuja jokapäiväisestä elämästä. Tämä yhteys kokonaisuuteen auttoi minua ymmärtämään aineiston osasia. Samalla piirsin aineiston kautta laajempaa kuvaa ammattilumilautailukentästä. Näin käsittelin aineistoa hermeneuttisen tradition mukaisesti kokonaisuutena, joka sai merkityksiä myös siitä kulttuurisesta kontekstista, jossa haastateltujen näkemykset oli tuotettu (Prasad 2005, 35). Tutkimuskohteeseen jatkuneen vuorovaikutuksen vuoksi tiedostin myös systemaattisen koodaamisen ja teoreettisen viitekehyksen erityisen tärkeyden oman tutkimusprosessini kululle. Ilman systemaattista koodaamista ja teoreettisia viitekehyksiä olisin saattanut kysyä aineistolta ilmeisiä ja pintapuolisia kysymyksiä ilman, että aineisto olisi haastanut tekemään syvällisempää tulkintaa (ks. Braun \& Clarke 2006).

\subsection{Ensimmäisen osatutkimuksen toteutus: lumilautailijoiden näkemyksiä itseilmaisusta}

Tutkimuksen ensimmäisessä osaongelmassa tarkastelin sitä, kuinka suomalaislumilautailijat sopeutuvat ammattilaislumilautailukentän instituutioihin. Lähestyin tutkimusongelmaa seuraavan tutkimuskysymyksen kautta: Kuinka lumilautailijat tulkitsevat mahdollisuutensa itsensä ilmaisuun ammattilumilautailukentän lähivuosien muutosten seurauksena? Syy tämän tutkimuskysymyksen valikoitumiseen oli aiemmissa tutkimuksissa, jotka näkevät itsensä ilmaisun yhtenä urheilun keskeisistä tehtävistä (esim. Grove \& Dodder 1982; Majors 2001; Wiley, Shaw \& Havitz 2000). Liikuntahistorioitsija Duncan Humphreysin (2003) mukaan pyrkimys itseilmaisuun on lumilautailussa jopa vahvempi kuin perinteisissä urheilulajeissa. Toisaalta nuorisokulttuuristen lajien kaupallistuminen ja institutionalisoituminen on muuttanut lajien luonnetta, mikä taas on voinut vaikuttaa niiden kykyyn tarjota keinoja itseilmaisulle. Näin ammattilumilautailukentän instituutioihin sopeutuminen voi hahmottua hyvin sitä kautta, 
kuinka lumilautailijat tulkitsevat omat mahdollisuutensa itseilmaisuun ammattilumilautailun kentällä.

Ensimmäinen osatutkimukseni rakentui tutkimuksen perusaineistosta erilleen ottamilleni lumilautailijoiden haastatteluille. Osatutkimus sai vaikutteita urheilututkimuksista, joissa organisatorista institutionalismia on käytetty teoreettisena viitekehyksenä tutkittaessa norjalaisia urheiluseuroja (Skille 2011) ja englantilaisen rugbyliiton ammattimaistumista (O'Brien \& Slack 2003; 2004). Käytin tutkimuksessa W. Richard Scottin uuden instituutiotutkimuksen koulukuntaan luettavaa teoreettista viitekehystä, jota täydensin skandinaavisen instituutiotutkimuksen koulukunnan ajatuksilla.

Koodaamisen aikana pilkoin aineistoa värittämällä ja ottamalla esimerkkejä erilleen, sekä ryhmittelin sitä uudelleen piirtelemällä kaavioita ja kirjoittelemalla muistioita (Braun \& Clarke 2006). Huomattuani aineistossa taipumuksen puhua kilpalumilautailusta ja kuvauslumilautailusta erillisinä alakenttinä, joissa saattaisivat toimia eri institutionaaliset elementit ja jopa eri lumilautailijat, koodasin näitä kommentteja systemaattisesti ja piirsin alakentistä kuvion ymmärtääkseni alakenttien eroja lumilautailumaastojen valmisteluasteen ja vauhtien suhteen. Tämän kuvion piirtämiseen tarvitsin lisätietoa vauhdeista ja maastojen valmistelemisesta. Hankin lisätiedot soittamalla neljä puhelua aiemmin haastattelemilleni informanteille. Kuvio auttoi minua hahmottamaan kahden alakentän ilmenemistä lumilautailussa konkreettisesti ja luottamaan analyysiini institutionaalisten elementtien jakautumisesta ammattilumilautailun kentällä.

Sen jälkeenkoodasin aineistosta Scottin $(2001 ; 2008)$ tutkimuksen mukaisia institutionaalisia elementtejä (regulatiiset, normatiiviset ja kulttuuriskognitiiviset), jotka olivat lumilautailukentän kehitystä koskevien, arvolatautuneiden, lumilautailijoiden näkemysten takana. Seuraavaksi koodasin niitä seurauksia, jotka lumilautailijat mainitsivat näistä institutionaalisista elementeistä seuraavan (liite 3). Tarkastelin koodauksen tuloksia lumilautailuhistorian ja niiden arvojen valossa, joita lumilautailukulttuurissa on arvostettu. Kutsun näitä arvoja tutkimuksessa lumilautailun perinteiseksi eetokseksi. Perinteisen eetoksen käsite sisältää sellaisen lumilautailun kehityksen arvostamisen, joka mahdollistaa lajin harjoittajien kontrollin, taiteellisen herkkyyden ja vapauden itsensä ilmaisemiseksi. Kyseiset arvot ovat tutkimusten (Beverland, Farrelly \& Quester 2010; Humphreys 1996; 2003) mukaan olleet arvostettuja lumilautailussa läpi vuosikymmenien. Lisäksi tarkastelin löydöksiä mainittujen instituutioteorioiden valossa.

Näiden sisällönanalyysin osasten avulla pyrin käsitteellisemmälle ymmärryksen tasolle (Ruusuvuori, Nikander \& Hyvärinen 2010). Käytin osallistujien haastatteluja raportoinnissa ilman nimiä. Esimerkit valitsin sen perusteella, että ne olivat tyypillisiä ilmentymiä kustakin esitellystä ilmiöstä. 


\subsection{Toisen osatutkimuksen toteutus: median rooli esiin aiempien tutkimusten kautta}

Tutkimuksen toisessa osaongelmassa oli tarkoituksena pohtia median roolia suomalaislumilautailijoiden uralla. Median roolia sivusin hieman jo ensimmäisessä artikkelissani. Tutkimuksen haastatteluaineistossa ilmeni selvä mediamuotojen murros, mikä näkyi eri aikaan haastateltujen informanttien vastauksissa. Median nopea kehitys sai minut epäilemään haastatteluaineistoni ajankohtaisuutta. En kokenut lopulta median roolin tarkastelua ammattilumilautailussa tämän aineiston pohjalta mielekkääksi. Lisäksi verkkomediaa oli tutkittu nuorisokulttuurisessa liikkumisessa niin vähän, ettei tämän tutkimuskirjallisuuden avulla ollut mahdollista piirtää taustaa sille ilmiölle, jota olin lähdössä etsimään aineistostani.

Koin median roolin lumilautailijoiden kiinnittymisessä ammattilaisuuteen kuitenkin niin keskeisenä, että näin tarpeelliseksi käydä läpi aiemmat tutkimukset median roolista nuorisokulttuurisessa liikkumisessa kyetäkseni valottamaan edes jollain tavoin median roolia suomalaisten lumilautailijoiden kiinnittymisessä ammattilaisuuteen. Teimme Hannu Itkosen kanssa katsaustutkimuksen, jossa asetimme kolme tutkimuskysymystä: 1) Millä tavoilla media on osa nuorisokulttuurista liikkumista? 2) Millaisia eri median muotoja tutkijat nostavat esiin nuorisokulttuuriseen liikkumiseen liittyen? 3) Kuinka eri median muotojen oleminen osana nuorisokulttuurista liikkumista vaikuttaa nuorisokulttuuristen lajien rakenteisiin ja harrastamiseen?

Osatutkimuksen aineiston keräsimme tekemällä hakuja hakupalvelimissa ja tietokannoissa. Tutkimuksen aineisto kertyi Google Scholarin ja Melindan avulla. Tarkistimme myös Arton, Sportdiscusin ja World of Sciencen tarjonnan, mutta ne eivät tarjonneet mitään, mitä emme olleet löytäneet vielä Google Scholarista ja Melindasta. Aineiston tutkimukset löytyivät käyttämällä hakusanoja nuorisokulttuurinen liikkuminen, action sport, lifestyle sport, extreme sport ja alternative sport, sekä neljän viimeisen hakusanan suoria suomennoksia. Löytynyttä aineistoa rajasimme hakemalla aineiston sisältä sisältöä media-, online- ja internet-termeillä. Toimiessamme Google Scholarin kaltaisen hakukoneen kanssa olimme tietoisia siitä, että hauissa saattaa näkyä painotusta sen mukaan, mitä olemme hakukoneella hakeneet aikaisemmin. Scholarin avulla saimme kuitenkin haaviimme paljon sellaisia tutkimuksia, joita muut hakukoneet eivät löytäneet.

Hylkäsimme lähtökohtaisesti kaikki markkinointipainotteiset tutkimukset, joilla ei selvästi ollut yhteiskuntatieteellistä lähestymistapaa. Lisäksi Google Scholar toi eteemme neljä heikkotasoista tutkimusta sekä kaksi kirjaa, joita emme tavoittaneet. Nämä rajasimme aineistosta pois. Lisäksi poistimme aineistosta yhden ympäristötutkimuksen ja yhden mediateknologisen tutkimuksen, koska ne eivät tarjonneet yhteiskuntatieteellistä kosketuspintaa. Hyväksyimme kuitenkin aineistoomme yhden tieteellisen raportin sekä useiden tutkijoiden viittaaman journalistisen historiikin. Otimme aineistoon mukaan myös kolmen 
nuorisokulttuurista liikkumista käsittelevän artikkelikokoelman (Rinehart \& Sydnor 2003; Wheaton 2004; Atkinson \& Young 2008) artikkelit niiltä osin, kun niissä käsiteltiin mediaa. Näin varmistimme, että katsauksemme sisältää myös nuorisokulttuurisen liikkumisen peruskirjallisuuden. Vaikka aineiston muodostaminen sisälsi perkaamista ja subjektiivista valintaa suhteellisen paljon, koimme aineiston tarjonneen näkemyksiä median roolista nuorisokulttuurisessa liikkumisessa monesta eri suunnasta. Ainoastaan sosiaalisen median osalta tietoa tuntui olevan niukasti joustavasta tiedonhaustamme huolimatta.

Väitöskirjan toinen osatutkimus hyötyi Sarah Thorntonin (1996) brittiläistä rave-kulttuuria tarkastelevasta tutkimuksesta, jossa Thornton paikallistaa median roolin keskeiseksi alakulttuurien muodostumisessa ja ylläpidossa. Jäsentelimme aineistoa tutkimuskysymysten mukaisesti kolmella koodilla: median muodot; median roolit; mediamuotojen vaikutus. Muokkasimme Thorntonin (1996) massamedian, erikoismedian ja mikromedian nykypäivään sopivasti valtavirtamediaksi, erikoismediaksi ja sosiaaliseksi mediaksi, mikä ohjasi etsintäämme ensimmäisen koodin mediamuotojen kanssa. Toisen ja kolmannen koodin kohdalla tukeuduimme Thorntonin (1996; 2005 [1995]) näkemyksiin alakulttuurisesta pääomasta ja eronteoista suhteessa emokulttuuriin. Etsimme median tapoja olla osana nuorisokulttuurista liikkumista ja niiden rakenteellisia ja harrastamiseen liittyviä vaikutuksia. Raportointikehikoksi valikoimme Thorntonin mediajaottelun pohjalta synnyttämämme kolmijaon.

\subsection{Kolmannen osatutkimuksen toteutus: valmentajien rooli lumilautailijoiden kokemana}

Tutkimuksen kolmannessa osaongelmassa tarkastelimme Holly Thorpen kanssa valmentajan roolia suomalaisten lumilautailijoiden urilla. Tutkimuskysymykseksi määrittyi se, millaisia havaintoja suomalaiset lumilautailijat tekevät valmentajien roolista omilla urillaan. Käytimme aluksi tutkimuksen perusaineistoa myös tämän tutkimuksen aineistona. Koodattuamme aineiston valmentajan hyötyjä avaavalla koodilla totesimme, etteivät suomalaiset lumilautailijat koe juurikaan tarvitsevan valmentajia urillaan Paul Potrackin ja Tania Cassidyn (2006) valmennustutkimuksessaan mainitsemana kokeneempana lajitietäjänä. Tämän jälkeen koodasimme aineiston uudestaan etsien niitä välineitä, joita lumilautailijat toteavat keskeisiksi taitojen opettelussa. Merkittäväksi tekijäksi nousi vertaisvalmennus. Näistä tuloksista kirjoitimme ensimmäisen käsikirjoituksen. Käsikirjoitus kaatui kuitenkin kansainvälisen valmennusjournalin hylkäykseen. Monien muiden kommenttien lisäksi vertaisarvioijat kaipasivat tutkimukseemme selvempää näkemystä toimintamalleista, joita valmentajat voisivat hyödyntää lukiessaan kirjoituksemme. Vertaisvalmennusta emme hylänneet käsitteenä; niin olennaisena se näyttäytyi ensimmäisessä datassamme.

Lähetimme kahdeksalle lumilautailijalle sosiaalisen median kautta viestin, jossa pyysimme heitä vastaamaan neljään valmentajan roolia koskevaan kysy- 
mykseen. Halusimme varmistusta siitä, että valmentajan roolin tutkiminen lumilautailijoiden uralla on yhä niin mielenkiintoinen aihe, että jaksamme nähdä sen vaivan, jonka osatutkimuksen jatkaminen vaati. Saimme takaisin viisi vastausta, jotka vahvistivat aiemman analyysimme tulokset. Olimme vakuuttuneita, että kentälle palaaminen ja lisäaineiston kerääminen on tutkimisen arvoista.

Päätimme kerätä lisää aineistoa selittääksemme lumilautailijoiden penseää suhtautumista valmentajan tarpeellisuuteen, mikä ei tullut riittävän systemaattisesti perusaineistossa esiin vakuuttaaksemme valmennustutkijat. Skiexpomessujen lähestyessä vuonna 2013 pyysin erästä Suomen Lumilautaliiton hallituksen jäsentä nimeämään kaikki sellaiset suomalaiset ammattilumilautailijat ja puoliammattilaiset, jotka todennäköisesti saapuisivat Skiexpo-messuille. Lisäksi kyseinen hallituksen jäsen määritti lumilautailijat sen perusteella, olivatko he kilpailuihin vai mediatuotantoihin keskittyviä lumilautailijoita. Halusimme myös tutkimuksessamme tuoda ensimmäistä käsikirjoitusta selvemmin esiin lumilautailijan suhteen kilpalumilautailuun tai kuvauslumilautailuun, koska koimme tämän tekijän voivan selittää löydöksiä.

Käytimme nimilistaa haastateltavien valikointiin siten, että pyrin tavoittamaan messuilla kaikki mahdolliset listassa esiintyneet henkilöt kysyäkseni heiltä viisi puolistrukturoitua valmentajan roolia koskevaa kysymystä (liite 2). Informanttien valikoitumiseen pyrin keruutilanteessa vaikuttamaan vain siten, että tarkistin ensimmäisen haastattelupäivän jälkeen, että olen haastatellut naisia ja miehiä, kilpailijoita ja kuvauslaskijoita, ammattilaisia ja puoliammattilaisia. Uusi kysymysrunko oli muutoin sama kuin sosiaalisen median kautta lähetetty, paitsi että yksi kysymys oli jaettu kahdeksi siten, että saimme selville paremmin, oliko informantilla aiempaa historiaa valmentajien kanssa työskentelystä. Lisäksi kysymysrunkoon oli merkitty mahdollisia lisäkysymyksiä, joita tuli esittää aina tarpeen mukaan. Sosiaalisen median kautta tavoitettuja vastaajia en enää yrittänyt tavoittaa.

Sain haastateltua Skiexpo-messuilla kahden päivän aikana kymmenen informattia. Lisäsimme nämä haastattelut sosiaalisen median kautta kerättyyn aineistoon ja aloitimme koodaamisen tälle aineistolle saadaksemme vastauksia siihen, millaisia havaintoja suomalaiset lumilautailijat tekevät valmentajien roolista omalla urallaan. Jatkoimme kuitenkin tätä ensisijaista tutkimuskysymystä toisella kysymyksellä, joka toi tutkimusasetelmamme lähemmäs sosiologista valmennustutkimuksen kenttää: Kuinka lumilautailun omaleimainen arvorakennelma tulisi ottaa huomioon rakennettaessa toimivaa urheilija-valmentajasuhdetta? Osatutkimus jakautui työvaiheissa lopulta kahtia: Ensimmäisen kysymyksen kohdalla koodasimme aineistoa "valmentajan hyödyt" koodilla mahdollisimman aineistolähtöisesti (ks. liite 3). Tällöin teemoittelimme neljä erilaista näkemystä valmentajan roolista lumilautailijoiden urilla ilman koodien yhdistelyä. Tämän työvaiheen jälkeen pyrimme ymmärtämään löydöksiä lumilautailukulttuurin arvojen suunnasta (Humphreys 1996; 2003; Beverland, Farrelly \& Quester 2010; Thorpe \& Wheaton 2011; Thorpe 2007; 2009c; 2011, 23) sekä löytämään valmennukseen lähestymistavan, joka tarjoaisi tilaa lumilautai- 
lukulttuurin omaleimaisille arvoille, ja joka noudattelisi teemoittelun kautta tulkitsemiamme hyötyjä valmentajasta.

Lumilautailijoille ominaiset oppimistavat, jotka sopivat myös lumilautailukulttuurin arvoihin, olivat hyvin samankaltaisia, joita ongelmakeskeisessä oppimisstrategiassa suositaan. Tukeuduimme siis Saveryn ja Duffyn (1995) perinteikkääseen sekä Hmelo-Silverin ja Eberbachin (2012) uudempaan tutkimukseen ongelmakeskeisestä oppimisesta. Tarkastelimme kyseisen lähestymistavan mahdollisuuksia lumilautailukulttuurin arvojen ja urheilijan menestyspyrkimysten yhteensovittamiseksi urheilijan ja valmentajan työskentelyssä. Koimme pedagogisen lähestymistavan löytämisen tärkeäksi paitsi ensimmäisen vertaisarvioinnin kommenttien vuoksi, myös sen empiirisen havainnon takia, että valmentajia esiintyy yhä enemmän lumilautailukilpailuissa lumilautailijoiden taustajoukoissa. Oletimme, että tulevan artikkelimme lukijakunta saattaisi hyvinkin hyötyä oikeanlaisten yhteistyömuotojen kehittelystä nuorisokulttuuristen lajien valmennussuhteisiin.

\subsection{Neljännen osatutkimuksen toteutus: lumilautailijan resursointi lautailijoiden ja managerien näkemyksissä}

Tutkimuksen neljännessä osatutkimuksessa tarkastelin suomalaisten lumilautailijoiden uran mahdollistavaa rahoitustaustaa. Tutkimus perustui perusaineistolle, josta hyödynsin sekä lumilautailijoiden että urheilumanagerien ja sponsorien team managerien haastattelut. Kun osatutkimus eteni, tutkimusongelman fokus muuttui rahoitustaustasta resursointiin, sillä tutkimus sivusi pelkkien rahansiirtojen sijasta myös lumilautailijoiden tietynlaiselle rahoitustaustalle otollista tekniikan ja yhteiskuntajärjestelmän kehittymistä. Tutkimuskysymykset kuitenkin keskittyivät lumilautailijoiden uran mahdollistavaan rahoitukseen kahden kysymyksen suunnasta: 1) Ketkä rahoittavat lumilautailijoiden uraa ja miten sekä 2) millaista lumilautailijan uratoimintaa rahoittajat haluavat kehittää ja ylläpitää?

Jäsentelin aineistoa koodausvaiheessa kolmella koodilla: kuka maksaa; miten maksaa; mistä maksaa. Lisäksi loin koodausvaiheessa aineistolle taustaa kysymällä, keitä aineiston lumilautailijat ovat, eli asettamalla heitä ammattilumilautailukentän genreihin ja katsomalla, mistä osasta Suomea he ovat lähtöisin. Piirtelin jälleen paperille hahmotelmia koodausvaiheessa, mikä tämän osatutkimuksen kohdalla tarkoitti taulukoita vastausten teemoista (liite 3).

Koodauksen jälkeen hahmottelin tutkimuksen löydöksiä Mikael Lindfeltin (Lindfelt 2007; 2010) huippu-urheilukategorioiden avulla, minkä jälkeen selitin lyhyesti löydösten asettumista Lindfeltin kategorioihin ja niiden ulkopuolelle urheiluhistorian ja kulttuurintutkimusten (Hartley 2005a; 2005b; Ilmanen 2005; 2012) avulla. Resursointia tarkastelin tutkimuksessa vain tukena, vaikka se voi aiheuttaa urheilijalle myös paineita. 


\subsection{Viidennen osatutkimuksen toteutus: lumilautailijoiden urheilu-urien tavoitteet}

Viimeisen osatutkimuksen aiheena oli nuorisourheilun sosialisaatioympäristöihin kuuluvat tavoitteet. Tarkastelimme Hannu Itkosen kanssa tehdyssä artikkelissa lumilautailussa ilmeneviä, tavoitteita koskevia, normeja ja vertasimme niitä aiempien tutkimusten löydöksiin moderneissa urheilukulttuureissa vaikuttavista tavoitenormeista. Hyödynsimme tutkimuksen perusaineistosta lumilautailijoiden haastattelut.

Koodasimme ja teemoittelimme lumilautailijoiden tavoitteita aineistolähtöisesti (Braun \& Clarke 2006), joskin tiedostimme huomaavamme helposti lukeneisuutemme vuoksi säännönmukaisuuksia, jotka koskivat lumilautailukilpailuja ja -mediatuotantoja (Ojala 2014), vapauden ja luovuuden pyrkimyksiä (Hänninen 2007; Ojala 2014; Humphreys 2003) sekä tyylillistä, kielellistä ja taidollista erottautumista (Thorpe 2011, 115-138, Hänninen 2012). Jätimme urheilulajin paremman teknisen hallitsemisen huomioitta, koska tulkitsimme sen tautologisena tavoitteena urheilijoiden urilla. Löysimme 11 koodia, joista jätimme löydökset sponsorien, mediayhtiöiden ja kilpailuorganisaatioiden hyödyttämisestä käsittelemättä, koska artikkelin pituus oli tarkasti rajattu. Jäljelle jääneistä kahdeksasta koodista yhdistelimme kuusi teemaa, joiden yhdistelyistä olen esittänyt esimerkin liitteessä (3) Vertasimme löytämiämme teemoja moderneissa urheilukulttuureissa aiempien tutkimusten mukaan vallinneisiin tavoitteisiin (Dunning 1999, 71-72; Laine 1992; Itkonen 2003; Kokkonen 2008). Tarkastelimme, mitkä lumilautailun sosialisaatioympäristössä ylläpidetyt tavoitteet ovat modernin urheiluperinteen jatketta ja mitkä haastavat sitä. Modernista urheiluperinteestä poikkeavia tavoitteita tarkastelimme Pushkala Prasadin (2005, 211-239) ja Steven Seidmanin (1994) tutkimuksissaan kokoamien, jälkimodernille ajalle tyypillisiksi tulkittujen ideologisten virtausten valossa.

\subsection{Aineisto sekä itsenäisenä kokonaisuutena että keräyskontekstiinsa sidottuna}

Lumilautailua on tyypillisesti tutkittu liikkumismuotona, jonka aatemaailma tarjoaa vaihtoehtoisuutta perinteisiin lajeihin nähden (Humphreys 1996; 1997; 2003; Thorpe \& Wheaton 2011; Thorpe 2011). Tämän aatemaailman perustavanlaatuisuus näkyy myös siinä, kuinka lumilautailu on tyypitelty vaikkapa nuorisokulttuurin tai elämäntapalajien kategorioihin. Aatemaailman keskeisyys aiempien lumilautailututkimusten tuloksissa on syy siihen, että tätä väitöskirjatyötä raamittaa hermeneuttinen suhde tietoon.

Organisaatiotutkija Anshuman Prasadin (2002; Prasad 2005, 30) mukaan hermeneuttista perinnettä seuraavien tutkimusten kirjo vaihtelee löyhästi ja tiukasti hermeneutiikkaa hyödyntävien tutkimusten välillä. Olen ottanut tiu- 
kasti hermeneuttista traditiota seuraavien metodien sijasta löyhästi vaikutteita hermeneuttisesta perinteestä. Hermeneutiikan noudatteleminen on tarkoittanut tässä tutkimuksessa analysoitavan aineiston tarkastelua osana nuorisokulttuurisille lajeille ominaista aatemaailmaa ja osana urheilun perinnettä, sekä toisaalta sen huomioimista, että nuorisokulttuuristen lajien aatemaailma ja urheilun perinteet realisoituvat tarkastelemissani ilmiöissä. Vaikka olen tiedostanut analyysivaiheessa tämän hermeneuttiseksi kehäksi kutsutun lähestymistavan paremman ymmärryksen saavuttamisesta, sekä pyrkinyt pääsemään ilmeisten oletusteni taakse tiedostamalla ne ja antamalla myös aineiston puhua (Gadamer 2004, 293-295), en ole käsitellyt missään vaiheessa hermeneuttista otetta systemaattisena työskentelytapana tai metodina, mikä kuitenkin sopii myös Gadamerin $(2004,25)$ alkuperäiseen ajatusmalliin.

Ensimmäisessä osatutkimuksessa peilasin lumilautailijoiden hyväksyviä ja huolestuneita asenteita lumilautailun aatemaailmaan niissä näkemyksissä, joita he esittivät ammattilumilautailun institutionalisoitumiskehityksestä. Aineistona toimi tutkimuksen perusaineisto. Toimme Hannu Itkosen kanssa aiempia tutkimuksia aineistonaan käyttävässä toisessa osatutkimuksessa esiin lumilautailun aatemaailman sijasta alakulttuuristen teorioiden perinteet, joiden valossa tarkastelimme löydöksiämme median roolista nuorisokulttuurisessa liikkumisessa. Aineistoksi valikoituivat aiemmat tutkimukset. Kolmas osatutkimus valotti suomalaisten lumilautailijoiden suhtautumista valmentajiin jälleen lumilautailulle ominaiseen aatemaailmaan peilaten. Aineiston tutkimuskysymykset rakentuivat perusaineiston analyysille, mutta tutkimuskysymykseen lähdimme vastaamaan sosiaalisessa mediassa ja Skiexpo-messuilla keräämiemme vastausten pohjalta. Neljäs tutkimus taas selitti ammattilumilautailuun kehittynyttä rahoitusmallia otollisella yhteiskuntajärjestelmään liittyvällä ideologialla. Aineistona oli jälleen tutkimuksen perusaineisto. Viides osatutkimus tarkasteli lumilautailijoiden tavoitteita suhteessa modernissa urheiluperinteessä ylläpidettyihin tavoitteisiin hyödyntäen perusaineistosta lumilautailijoiden haastatteluja. Vaikka olen siis pyrkinyt analysoimaan aineistoa itsenäisenä kokonaisuutenaan, olen myös palauttanut aineiston analyysivaiheessa osaksi sitä tapahtumahorisonttia, jossa aineisto on kerätty ja jossa informanttien mielipiteet muodostavat merkityksiä. Eri aineistojen hyödyntäminen eri artikkeleissa havainnollistuu kuvion 1 avulla. 
KUVIO 1 Tutkimuksen aineiston hyödyntäminen tutkimuksen vaiheissa.

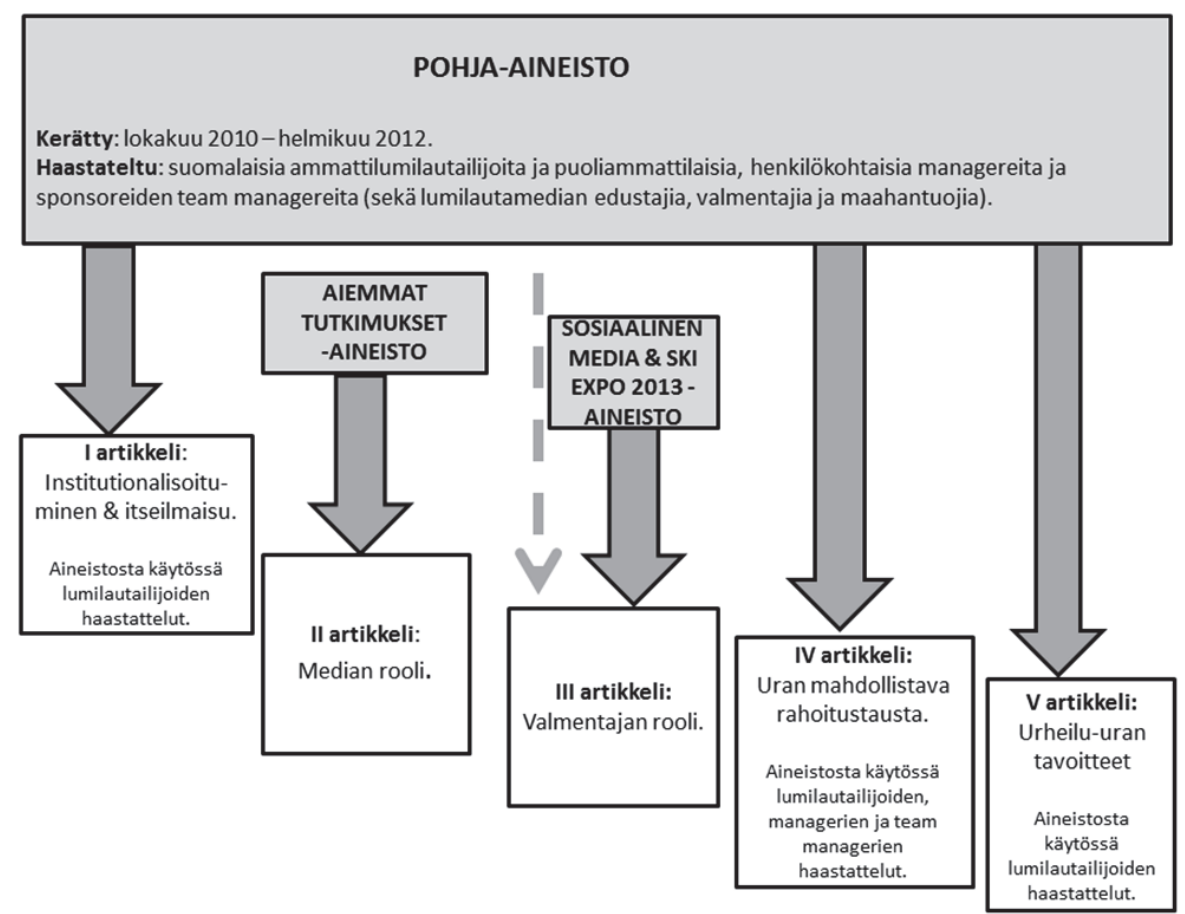

Kuvion harmaissa laatikoissa ovat kuvattuina tutkimuksen aineistot, joista ensimmäisenä keräsin perusaineiston, mutta jonka lisäksi tarvitsin puheluaineistoa, aiemmat tutkimukset -aineistoa sekä sosiaalisen median kautta ja Skiexpo-messuilla vuonna 2013 keräämääni aineistoa artikkelien tutkimusongelmien vastaamiseen.

Hermeneuttiseen perinteeseen sopivasti en missään tutkimuksen vaiheessa ajatellut tekeväni laadullisen positivismin tavoin objektiivista tiedettä ja analysoivani jotain ulkopuolista, vaan koen tuoneeni omia vivahteitani mukaan tulkintaan (Prasad 2005, 33). Lisäksi tartuin haastatteluja analysoidessani informanttien puheeseen heidän tapanaan hahmottaa ja rakentaa maailmaa tietyssä kulttuurisessa kontekstissa sen sijaan, että olisin ajatellut vastauksia jotakin ilmiötä koskevina faktoina. Yhtä lailla kun tämä konstruktivistinen näkemys on ominainen laadulliselle tutkimukselle, antaa se tilaa niille ihmisen muistia tarkasteleville tutkimuksille (esim. Portelli 2009; Turrini 2013), jotka huomioivat ihmisen muistin monikerroksisuuden ja luovuuden näkemysten ja tapahtumien merkityksellistämisessä. 


\section{LÖYDÖKSET}

Seuraavissa alaluvuissa esittelen väitöskirjatutkimukseni keskeiset löydökset. Raportoin löydökset alaongelma kerrallaan päätyen löydösten yhteenvetoon.

\subsection{Suomalaisten lumilautailijoiden sopeutuminen ammattilumilautailukentän instituutioihin}

Tutkimuksen yksi keskeisistä löydöksistä oli ammattilumilautailun kahden alakentän - kilpalumilautailun ja kuvauslumilautailun - hahmottuminen erillisiksi kentiksi (kuvio 2), jotka rakentuvat eri institutionaalisille elementeille. Nämä kaksi alakenttää tarjoavat lumilautailijoiden tulkintojen mukaan erilaiset mahdollisuudet itseilmaisulle niiden erilaisten organisoitumismuotojen vuoksi. 
KUVIO 2 Lumilautailun organisoituminen suhteutettuna vauhdin ja maaston muokkaukseen.

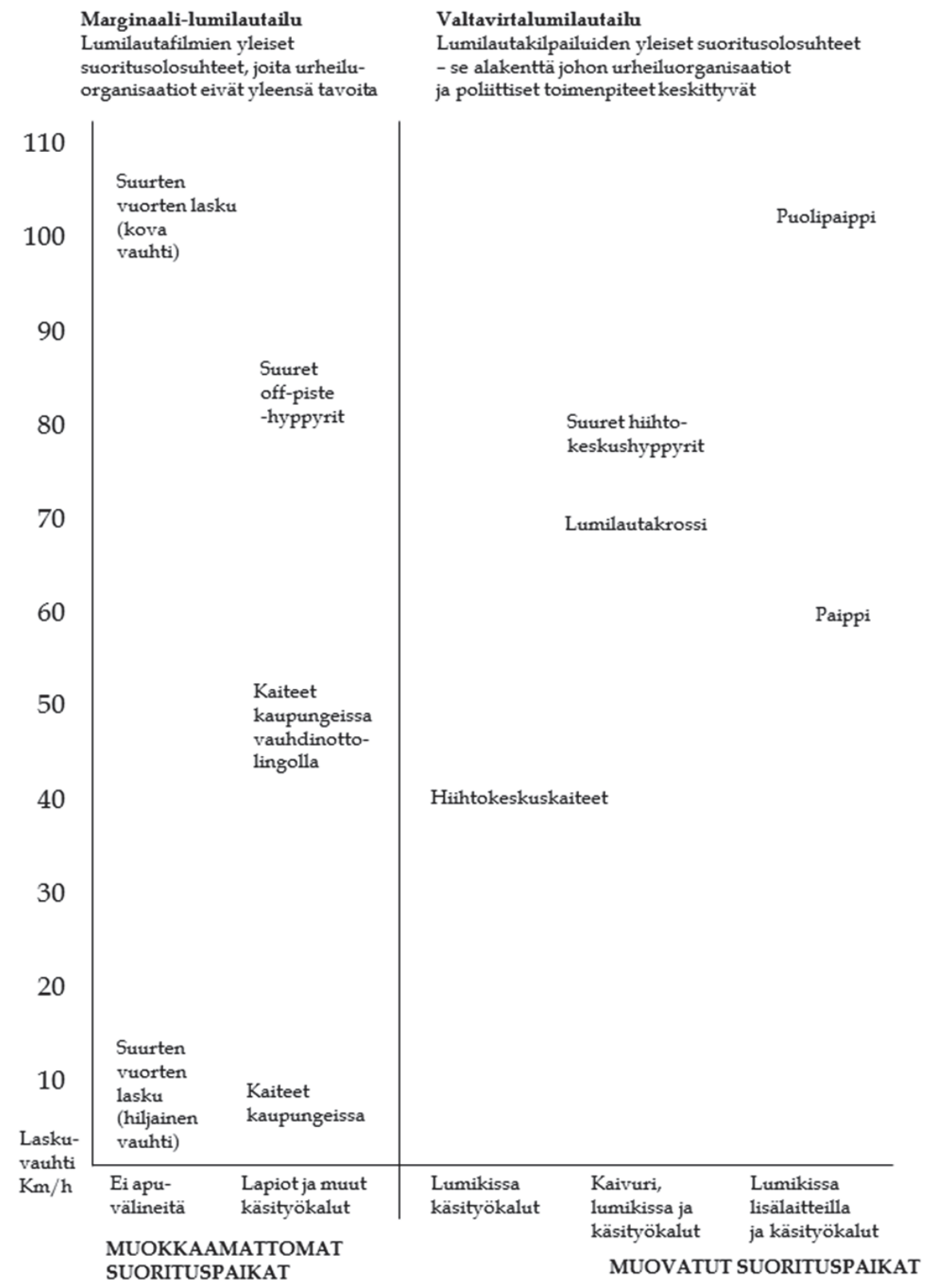

Kuvion 2 vasemmassa laidassa ovat kuvauslumilautailulle, eli lumilautailun erikoismedian ja sosiaalisen median tuotannoille tyypilliset maastot. Niitä valmistellaan enintään lapioin maastojen hyödyntämiseksi freestyle- 
lumilautailijoiden tarkoituksiin. Vähäinen valmisteluaste tarkoittaa myös sitä, että ympäristöt ovat muuttuvaisia - niin kutsuttuja luonnollisia ympäristöjä. Esimerkiksi kaupunkien kaduilla tai vuorten takamaastoissa tapahtuva lumilautailu joutuu sopeutumaan suorituspaikkoihin, joita ei ole suunniteltu lumilautailemista varten. Kuvion 2 oikeassa laidassa olevat maastot sen sijaan ovat kilpailuissa tavanomaisia ympäristöjä, joiden aikaansaamiseksi tarvitaan lapioiden lisäksi myös rinne- ja kaivinkoneita. Nämä ympäristöt voidaan standardisoida siten, että rata on kaikille sama, toisinaan jopa useassa kilpailussa. Toisaalta taas kilpailuille ominaiset lumilautailuympäristöt saattavat vähentää loukkaantumisriskiä, kun ympäristö on suunniteltu mahdollisimman hyväksi urheilusuorituksia varten.

Sekä kilpailujen että kuvaamisen alakentät tarjosivat lumilautailijoille areenoita taitojen näyttämiseen ja vertailuun sekä heidän sponsoreilleen mahdollisuuden saada kaipaamaansa näkyvyyttä. Lumilautailijat olivat ennen muuta kiitollisia sponsoreilleen ammattilaisuransa mahdollistamisesta. He olivat valmiita hyödyttämään sponsoreitaan eri keinoin, mikä tarkoitti normatiivisten elementtien, eli tässä tilanteessa rooliodotusten, vahvaa hyväksyntää (Scott 2001). Kuvaamisen alakenttä oli kuitenkin tutkimukseni mukaan arvostetumpi kuin kilpailemisen. Tämä arvojärjestys ilmeni siten, että kilpalumilautailun kentällä toimineet informantit kokivat tarpeelliseksi selitellä syitä sille, että he olivat valinneet tai ajautuneet kyseiselle alakentälle. Samaa tarvetta ei ilmennyt kuvaavien lumilautailijoiden puheessa.

Kilpailujen alakentän alemmasta arvostuksesta huolimatta kilpailujen kautta uraansa toteuttavat lumilautailijat eivät olleet millään lailla katkeria urapolkunsa vuoksi, vaan olivat kiitollisia siitä, että saattoivat toteuttaa rakasta harrastustaan ammattinaan. Tutkimus osoitti Czarniawskan ja Joergesin (1996) sekä Czarniawskan \& Sevónin (1996) ideoiden leviämisprosessin mallia hyödyntämällä, kuinka lumilautailijat kykenivät puheessaan kääntämään kilpailujen vertailevuutta ja äärimmilleen menevää progressiota arvostavan ideologian lumilautailun arvoihin paremmin sopivaksi. Lumilautailijat arvostivat kilpailemisessa korkeatasoisia lumilautailusuorituksia ja todistivat kokevansa intohimoa lumilautailua kohtaan jopa ahdistavissa kilpailuympäristöissä. Näin ollen tutkimus tuki Sahlin-Andersonin (1996), Greenwoodin ja kumppaneiden (2008) sekä Salinin ja Wedlinin (2008) näkemyksiä siitä, että ideoiden omaksumiseen vaikuttaa tunne siitä, mikä edistäisi toimijan pyrkimyksiä kussakin ympäristössä. Kilpalumilautailun kontekstissa omaksutut ideologiat ja toimintamallit käännettiin sellaiseen muotoon, että ne mahdollistivat lumilautailijalle sopivan elämäntavan ammattina juuri kilpailujen kautta. Näiden positiivisten kertomusten kautta lumilautailijat ylläpitivät omaa ammatti-identiteettiään.

Vaikka kilpailujen kautta uraansa toteuttavat lumilautailijat onnistuivat kääntämään kilpailujen toimintamallit ja ideologiat niin, etteivät ne olleet ristiriidassa lajin perinteisen eetoksen kanssa, olivat lumilautailijat yleisesti huolissaan siitä kehityskulusta, jota kilpailut edistävät. Lumilautailun muuttuminen vakavaksi urheiluksi ja lumilautailijoiden kontrollin menettäminen oman lajinsa kehityksestä aiheutti huolta lumilautailijoissa. Lumilautailijat syyttivät lajin 
ulkopuolisia toimijoita, kuten olympialaisia, FIS:iä ja massamediaa lumilautailulle harmillisesta kehityksestä. Tutkimus esittelikin Scottin (2001) mallia hyödyntäen sitä valtapeliä, joka urheilijoiden ja urheiluorganisaatioiden ympärille voi syntyä niiden taistellessa omien päämääriensä ajamisesta: niillä ideologioilla ja käytännöillä, joita massamedia ja olympialaiset ovat pyrkineet lumilautailussa institutionalisoimaan, ei ole lumilautailijoiden keskuudessa legitimiteettiä. Samaan aikaan nämä voimakkaat organisaatiot tuovat lajiin niitä resursseja, jotka mahdollistavat lumilautailijoiden ammattilaisuuden.

Lumilautailijat syyttivät FIS:iä regulatiivisten institutionaalisten elementtien edistämisestä lajissaan. Nämä elementit näkyivät kilpailuratojen, formaattien ja ilmaisuvapauden säätelynä. Samalla kun kilpailuorganisaatiot ovat tehneet lajista yhtenäisten ratojen, tuomarointilinjojen ja kilpailumuotojen myötä ymmärrettävää suurelle yleisölle, on säätely ristiriidassa lumilautailun perinteisen eetoksen kanssa. Säätely vaarantaa lumilautailijoiden luovan ilmaisuvapauden. Näin ollen kilpailuorganisaatioiden ajamia ideologioita ja käytäntöjä ei ole haluttu hyväksyä suoraan. Lumilautailijat kuitenkin huomasivat myös oman kilpailuorganisaationsa, TTR:n, omaksuneen niitä toimintamalleja, joita he vierastivat muissa kilpailuorganisaatioissa. Tulkitsin toimintatapojen yhtenäistymisen johtuvan samasta homogenisoitumisilmiöstä, jota tapahtuu DiMaggion ja Powellin (1983) mukaan silloin, kun kenttä alkaa vakiintua.

Ammattilumilautailun toinen alakenttä, kuvauslumilautailun kenttä näyttäytyi tutkimuksessa ihailtuna sen vuoksi, että sen nähtiin mahdollistavan luovuus, todelliset vaihtoehdot ja lumilautailijoiden päätösvalta. Nämä lumilautailun perinteiseen eetokseen sopivat kulttuuriskognitiiviset institutionaaliset elementit varmistivat alakentän legitimiteetin. Siten tämä alakenttä ei perustunut sääntelylle, vaan lumilautailijat jakoivat ymmärryksen alakentän toimintatavoista ja arvoista ja kokivat pääsevänsä itse päättämään omista valinnoistaan. Holly Thorpen $(2011,13)$ kirjassaan kuvailemaa tuntemusta sponsoreilta tulevista paineista lumilautakuvauksissa ei esiintynyt tämän tutkimuksen aineistossa. Lumilautailijat pikemminkin kokivat nauttivansa niistä moninaisista keinoista heidän taitojensa ja elämäntapansa esittelylle, joita kuvauslumilautailun alakenttä tarjosi.

Kuten edellä esitellyssä kuviossakin ilmenee, kuvauslumilautailussa ominaiset suorituspaikat ovat muuttuvaisia, eivätkä tuomarit kerro lumilautailijoille, millaiset temput johtavat arvostettuun asemaan. Kuvauslumilautailun alakentällä lumilautailijoiden taidot olivat siis jaetuista käsityksistä ja kontekstista (Scott 2001, 57-61) riippuvaisia; ne vaativat kulloistenkin trendien seuraamista ja kykyä ymmärtää, mitä kannattaa urallaan tehdä. Lisäksi lumilautailijat kokivat positiiviseksi sen, että he kykenivät antamaan kuvausmateriaalin kautta sponsoreilleen heidän kaipaamaansa alakulttuurista näkyvyyttä. Näin ollen kuvauksen alakentän legitimaatioperusta lepää laillisten ja näennäislaillisten sopimusten sijasta rakenteita ja identiteettejä koskevien yhteisten ymmärrysten sekä sisäistettyjen työntekijä-työnantaja-suhteiden varassa (Scott 2001, 54-56). Tulkitsin Lawrencen (2008) resurssien omistus -näkökulmia hyödyntäen, että lumilautailijoiden sponsorit ja mediatuotannot ovat niin riippuvaisia lumilau- 
tailijoiden persoonista, luovuudesta ja kyvyistä kehitellä uusia tyylejä ja tekniikoita, että sponsoreille ja mediatuotannoille olisi suorastaan harmiksi säännöstellä lumilautailijoiden ilmaisuun liittyviä merkityksiä ja toimintamalleja.

Vaikka lumilautakuvauksen alakentän jaetulle ymmärrykselle perustuvat toimintamallit aiheuttivat hyväksyntää enemmän kuin kilpalumilautailun alakentälle tyypillinen tapa säädellä toimintaa, aiheutti kuvauspuolen vapaamielinen toimintalogiikka myös huolta lumilautailusuoritusten tason heikkoudesta. Vaikka määrittelinkin kilpailujen ja kuvausten alakentät erillisiksi käsitteellisellä tasolla, liikkuvat ideat kilpailujen ja kuvauksien välillä ilman merkittäviä raja-aitoja. Lumilautailijat tietävät kehitystason kummallakin puolella, mikä aiheuttaa paineita lumilautailijoille erillisistä alakentistä riippumatta, ja tämä epävarmuus johtaa imitaatioon (Sevón 1996).

Piirsin kahden alakentän ja instituutiotutkimusten avulla tutkimuksessani kuvan ammattilumilautailusta ilmiönä, joka ei ole yhtenäinen toimintamalliensa suhteen. Lumilautailun kaksi erillistä alakenttää mahdollistivat erilaiset keinot lumilautailijoiden itseilmaisulle: Kilpalumilautailun alakentän äärilaita on siirtynyt yhä enemmän kohti säätelyä ja normatiivisuutta, mikä aiheuttaa ristiriitoja lumilautailun perinteisen eetoksen kanssa ja heikentää niitä lumilautailijoiden tapoja itseilmaisulle, joita he lajissaan perinteisesti arvostavat. Mahdollisuus omien mielipiteiden ja elämäntapojen esiintuomiselle on kilpailuareenojen säätelyn vuoksi rajoitetumpaa kuin erikois- ja sosiaalisen median tuotannoissa, koska kilpailuorganisaatiot omistavat kilpailujen areenat. Vaikka tutkimukseni löydökset antoivat ymmärtää, että lumilautakuvausten alakenttä mahdollisti paremmin lumilautailulle ominaisen itseilmaisun kuin lumilautailukilpailujen alakenttä, esitin tutkimuksessani myös kuvauskentän säätelemättömyyden vaikutuksista lumilautailijoiden itseilmaisun tasa-arvoisuudelle: Lumilautakilpailujen organisoitumismallit säätelyineen ja normeineen voivat olla sopivan läpinäkyviä niiden lumilautailijoiden itseilmaisulle, jotka eivät automaattisesti kykene saamaan tilaa kulttuuriskognitiivisiin elementteihin nojaavalla kuvauksen alakentällä. Esimerkiksi naiset eivät saa helposti omille suorituksilleen näkyvyyttä hyvin maskuliiniseksi tulkitussa lajissa (Anderson 1999; Thorpe 2006; 2008; 2009b; Sisjord 2009). Eräissä lumilautailukilpailuissa sen sijaan säännöt naisten ja miesten sarjoista varmistavat naisten statuksen varteenotettavina lumilautailijoina.

\subsection{Median rooli suomalaisten lumilautailijoiden uralla}

Toinen osatutkimus osoitti aiempien tutkimustulosten ja Thorntonin (1996; 2005 [1995]) teoreettisen välineistön avulla, kuinka valtavirtamedialla, erikoismedialla ja sosiaalisella medialla on jokaisella oma roolinsa nuorisokulttuurisessa liikkumisessa. Samoin kuin Thornton (1996, 128-129) esitti jo liki 20 vuotta aikaisemmin, päädyimme mekin Hannu Itkosen kanssa tehdyssä artikkelissamme sellaiseen johtopäätökseen, ettei valtavirtamediaa voi tulkita alakulttuurin ulkopuoliseksi toimijaksi. Vaikka valtavirtamedia valtavirtaistaa lajeja yksinker- 
taistamalla ja kaupallistamalla niitä esimerkiksi mediakorporaatioiden omissa kilpailutapahtumissa, on valtavirtamedian moraalinen paniikki aiheuttanut Thorntonin (emt.) tulosten tavoin myös nuorisokulttuurisessa liikkumisessa alakulttuurin sisäisen identiteetin vahvistumista. Valtavirran moraalinen paniikki osoittaa alakulttuurin erityisyyden. Samalla valtavirtamedian tarjoamat areenat ovat näyttäytyneet urheilijoiden silmissä vaihtoehtoisina joillekin perinteisille urheiluorganisaatioille, kuten olympialaisille (Coates, Clayton \& Humberstone 2010). Näin ollen, vaikka esimerkiksi valtavirtamediaan kuuluvan ESPN-mediakorporaation on koettu X Games -kilpailuillaan urheilullistaneen nuorisokulttuurista liikkumista (Rinehart 2008a) ja vähentäneen sen alakulttuurisuutta, on valtavirtamedia ylläpitänyt alakulttuurista imagoa valtavirtayleisön silmissä ja vahvistanut alakulttuurista käytöstä myös lajien sisällä.

Erikoismedian rooli nuorisokulttuurisessa liikkumisessa on nähty tutkimuksemme kirjallisuudessa alakulttuurin sisäisenä toimijana, joka Thorntonin $(1996,151)$ tutkimustuloksia mukaillen luokittelee ilmiöitä arvolatautunein sanamuodoin ja opettaa jäseniä kuluttamaan ja toimimaan alakulttuurin arvojen ja ideologioiden mukaisesti. Näin erikoismedia siis opettaa alakulttuurin jäsenille alakulttuurisen pääoman kartuttamisen kannalta oleellisia seikkoja. Koska erikoismedian toimittajat ovat itse lajien harrastajia, välittävät he mediayleisön mielestä lajille autenttisia arvoja ja ideologioita, mikä taas tarjoaa voimakkaita keinoja identiteetinrakennukseen esimerkiksi ruumillisten käytänteiden ja hierarkioiden opettamisen kautta. Wheatonin ja Bealin (2003) tutkimuksen mukaan juuri alakulttuurista identiteettiään etsivät lajin harrastajat ovat erikoismedian aktiivisessa yleisössä enemmistöä. Näin ollen esimerkiksi monien nuorisokulttuuristen lajien maskuliinisuus ja keinot ylläpitää sitä välittyvät lajien harrastajille huomaamatta.

Alakulttuurin sisäinen media ei ole yritysmaailmasta erillinen toimija, vaan kaupallinen yhteistyö on vankkaa medioiden rahoittamisessa ja kaupallisten brändien luomisessa ja ylläpidossa. Erikoismedian ja kaupallisten toimijoiden tiivis yhteistyö, jossa ammattiurheilijoilla ja puoliammattilaisilla on merkittävä tehtävänsä, on luonut nuorisokulttuurisiin lajeihin sekä kilpailuista poikkeavia areenoita taitojen näyttämiselle että urheilijoille mahdollisuuksia edetä urallaan ilman kilpailujen käymistä.

Olimme tätä tutkimusta tehdessämme yllättyneitä, kuinka vähän verkkomedian ja nuorisokulttuurisen liikkumisen kohtaamisia on tutkittu, vaikka virtuaalikommunikaation tutkiminen on ollut alakulttuuritutkimuksessa arkipäivää jo yli 20 vuotta (Wilson 2008). Tutkimuksemme havaitsi aiempien tutkimusten käsitelleen verkkomediaa nuorisokulttuurisessa liikkumisessa paikasta riippumattomien yhteisöjen luojana. Verkkomediavälitteiset yhteisöt häivyttivät niitä nuorisokulttuurisen lajien harrastajien sosioekonomisen ja biologisen taustan ominaispiirteitä, jotka kasvokkaisissa yhteisöissä olisivat läsnä. Verkkomedian toimintatavat hämärsivät tutkimuksemme mukaan myös muita perinteisempien mediamuotojen kategorioita: kaupallisuus ja ei-kaupallisuus, sekä mediakäyttäjän ja -tuottajan rajat häilyivät verkkomedian ja nuorisokulttuurisen liikkumisen kohdatessa. Lisäksi lajikäytännöt sekoittuivat mediakäytän- 
töihin, kun harrastajat etsivät verkon kautta uusia suorituspaikkoja ja jakoivat tallenteita suorituksistaan verkossa. Verkkomedian kautta nuorisokulttuurisiin lajeihin oli tullut myös harrastajia, joille mediaympäristöt olivat liikkumisympäristöjä tutumpia.

Tutkimuksessamme huomasimme, että verkkomedian roolin hahmottaminen nuorisokulttuurisessa liikkumisessa on yhä aiempien tutkimusten perusteella hankalaa. Tutkimuksemme aineistossa ei vielä pohdittu lainkaan verkkomedian valtavirtaisuutta tai alakulttuurisuutta. Epäilemme, ettei kaikki verkkomedian materiaali ole nuorisokulttuuristen lajien harrastajille samanarvoista. Joitakin verkkomateriaaleja pidetään alakulttuurisesti autenttisempina kuin toisia. Tämä aihepiiri vaatisi kuitenkin osakseen oman tutkimuksensa. Emme kyenneet artikkelissamme tarttumaan vielä tähän tutkimustehtävään.

\subsection{Valmentajien rooli suomalaisten lumilautailijoiden uralla}

Holly Thorpen kanssa tekemämme osatutkimuksen teemoittelu 15 suomalaisen ammattilumilautailijan ja puoliammattilaisen haastatteluaineistolle paljasti neljä eri pääteemaa niistä rooleista, joita lumilautailijat antoivat valmentajille omilla urillaan: 1) Valmentaja on hyödyllinen lumilautailutaitojen oppimiselle; 2) valmentaja on hyödyllinen fysiikkatreenin ja elämänhallintataitojen kannalta; 3) valmentaja on hyödyllinen managerina ja resurssien jakajana; 4) valmentaja on hyödytön.

Vain ensimmäisessä kategoriassa informantit kokivat valmentajan perinteisen valmentajamallin (ks. Cassidy, Jones \& Potrac 2009, 33) mukaisesti henkilönä, joka parantaa lumilautailutaitoja ja auttaa onnistuneisiin suorituksiin. Näin kokevia informantteja oli aineiston vastaajista vain kaksi ammattilaista ja kolme puoliammattilaista. Heistäkin jokainen silti painotti, ettei valmentaja voi korvata vertaisten tarjoamaa tietoa, ja vain yksi jätti mainitsematta sen, että valmentajan tulisi olla juuri lopettanut ammattilainen, joka osaa opettamansa temput itse. Ymmärrettävästi nopeasti kehittyvässä ja muuttuvassa lajissa valmentajan taitotasoa koskevan vaatimuksen täyttäminen on huomattavan hankalaa. Lumilautailijoiden näkemys yhteisöllisen oppimisen hyödyntämisestä oli kuitenkin ehdoton sellaiselle valmentajalle, jonka lumilautailijat kokisivat hyödyttävän itseään.

Viidestätoista informantista kolme arvosti omia kokemuksiaan valmentajista fysiikkansa treenaamiselle, ja kaksi puoliammattilaista arvosti valmentajan näkemyksiä fysiikkatreenin lisäksi myös henkiseen valmentautumiseen. Lisäksi kaksi informanttia mainitsi valmentajan mahdollisesti hyödylliseksi sellaisille nuoremmille lumilautailijoille, joiden tulisi oppia hyviä elämänhallintataitoja.

Kolmannessa teemoittelun paljastamassa kategoriassa valmentaja näyttäytyi managerina ja resurssien hallinnoijana. Tähän kategoriaan kuuluneita kommentteja esittäneitä informantteja emme laskeneet siitä syystä, että osa informanteista kyseenalaisti vahvasti, voiko managerointia ja resurssien hallinnointia edes ajatella valmentajan tehtäväksi. Tutkimuksessa ilmeni kuitenkin useita 
kommentteja valmentajasta, joka olisi hyödyllinen lumilautojen vahaajana, matkojen järjestelijänä ja suoritusten filmaajana, mutta jolla ei kuitenkaan olisi lopulta sanan sijaa suoritusten sisältöihin.

Tutkimuksen teemoittelu osoitti mielenkiintoisen huomion, jolle emme tutkimuksessa lähteneet etsimään lopulta vastausta: haastatellut naislumilautailijat kokivat valmentajan pääosin hyödylliseksi lumilautailutaitojensa kehittämisessä, kun taas suurin osa mieslumilautailijoista epäili valmentajan hyödyllisyyttä samaan tarkoitukseen. Mieslumilautailijoiden näkemykset eivät johtuneet kokemusten puutteesta valmentajien kanssa työskentelyssä. Valmentajakokemuksista huolimatta - tai ehkä niistä johtuen - valmentajan hyödyttömyyttä alleviivaavat kommentit olivat aineistossa enemmistönä. Informanttien mukaan vertaisilta oppii enemmän ja paremmin kuin valmentajilta; ja toisaalta jos lumilautailijalla ei ole motivaatiota oppimiseen, eivät informantit nähneet valmentajan kykenevän muuttamaan tilannetta riittävästi. Informantit oppivat toisilta lumilautailijoilta tietoja ja taitoja lumilautailutekniikoihin ja tyyleihin liittyen. Toisaalta samat informantit saattoivat olla epätietoisia siitä, millaisia rooleja valmentajan voisi odottaa ottavan. Laudan voitelun tai matkojen järjestämisen he kokisivat hyödyllisenä, mutta nämä tehtävät kuuluisivat heidän mielestään mahdollisesti jollekin toiselle henkilölle kuin valmentajalle.

Yksi tutkimuksen keskeisistä löydöksistä oli, että ammattilumilautailija tarvitsee menestyäkseen myös vertaisten arvostusta, eikä arvostusta saa toimimalla lumilautailukulttuurin arvojen vastaisesti. Tämä arvostus vaikuttaa mahdollisuuteen luoda uraa niin keskeisesti, että myös valmennussuhteiden tulisi ottaa lumilautailukulttuurin omaleimaiset arvot huomioon. Omaehtoisuus on lumilautailun yksi tärkeistä arvoista, minkä myös lumilautailijan tulisi olla omaksunut tämän tutkimuksen perusteella. Tyylin ja luovuuden (Humphreys 2003) sekä vapauden, taidokkuuden ja alakulttuurisen yhteyden (Beverland, Farrelly \& Quester 2010) arvostaminen on aiempien tutkimusten perusteella lumilautailukulttuurissa niin keskeistä, ettei näihin arvoihin sosiaalistamista soisi häirittävän vääränlaisilla urheilija-valmentaja-suhteilla. Tulkitsimme omaehtoisuuden ja harrastajalähtöisyyden ihanteiden vaikuttaneen tutkimuksemme informanttien kommentteihin niin vahvasti, että he kokivat vertaissuhteiden tarjoaman hierarkiattomuuden itselleen hyödyllisempänä kuin sen valtasuhteen, johon he urheilija-valmentaja-suhteissa tutkimusten (Markula \& Pringle 2006; Denison \& Scott-Thomas 2010; Denison, Mills \& Jones 2013) mukaan väistämättä ajautuisivat.

Tutkimuksemme tehtävään liittyi lisäksi sellaisen pedagogisen lähestymistavan löytäminen lumilautailun valmennussuhteisiin, joka mahdollistaisi lumilautailun arvojen säilyttämisen. Yritimme löytää strategian, jossa valmentajasuhde perustuisi hierarkiattomuudelle, lumilautailijan omaehtoisuudelle ja vertaisten hyödyntämiselle.

Huomasimme tutkimuksemme informanttien kommenteista, että suurin osa hyvin menestyvistä suomalaisista lumilautailijoista tuntee oppivansa kaiken tärkeän lumilautailutaitoihin liittyvän omilta lumilautailukavereiltaan. Tehokas vertaisoppiminen on mahdollista, koska lumilautailijoilla on riittävä mo- 
tivaatio oppimiseen, he tiedostavat mitä he haluavat oppia, he huomaavat, kuinka oppimistavoitteet voidaan saavuttaa ja luonnolliset oppimisympäristöt tukevat taitojen hyödyntämistä tietyn oppimisympäristön ulkopuolellakin. Lumilautailijat näyttävät siis itse toimivan niiden periaatteiden mukaisesti, jotka ovat Hmelo-Silverin ja Eberbachin (2012) mukaan ongelmakeskeisessä oppimisstrategiassa keskeisiä. Voidaan kuitenkin olettaa, etteivät kaikki lumilautailijat löydä itsenäisesti tehokasta vertaisoppimisen ryhmää. Samalla yhä useampi lumilautailija myös pyrkii pärjäämään olympialaisten kaltaisilla kilpailuareenoilla, jolloin valmentautuminen voi näyttäytyä yhtenä keinona lisätä menestysmahdollisuuksia. Koska lumilautailun keskeisten arvojen omaksuminen ja noudattaminen on ammattilumilautailijan uralle elinehto, päädyimme suosittelemaan lumilautailijoiden itsenäisesti omaksumaa ongelmakeskeistä oppimisstrategiaa myös urheilija-valmentaja-suhteisiin.

Ongelmakeskeisen oppimisstrategian eduiksi tulkitsimme lumilautailijan ja hänen henkilökohtaisten tavoitteidensa asettamisen keskiöön, vertaisoppimisen keskeisyyden sekä hierarkiattomuutta painottavan lähestymistavan. Lumilautailijan henkilökohtaisten tavoitteiden asettaminen keskiöön tarkoittaa ammattilumilautailijoiden kohdalla sitä, että heidän tavoitteensa eivät välttämättä ole yhteneväisiä esimerkiksi Suomen Lumilautaliiton tai jonkun muun urheiluorganisaation tavoitteiden kanssa. Tämä tavoitteiden ristiriita, joka voi esiintyä vaikka silloin, kun lumilautailija asettaa lumilautailukuvaukset arvokilpailuiden edelle, ei ole ongelmakeskeisessä oppimisstrategiassa mahdollinen: oppijan oppiminen ymmärretään oppijan omien tavoitteiden myötä tapahtuvaksi. Valmentaja voi toki pyrkiä keskusteluilla avaamaan lumilautailijan omat tavoitteet hänelle paremmin näkyviksi, mutta valmentajan tehtävänä ei ole ohjata lumilautailijoiden tavoitteita sopimaan joidenkin ulkopuolisten intressien tavoitteisiin.

Ongelmakeskeinen oppimisstrategia toi eteemme myös sen valmentajan roolin, jonka tehtävänä on kyseenalaistaa oppijan ajatuksia (Savery \& Duffy 1995). Näimme lumilautailukulttuurin omaleimaisten arvojen olevan siinä tilanteessa myös haitallisia lumilautailijalle, jos hänen henkilökohtaiset tavoitteensa eivät istu lajikulttuurin arvoihin. Esimerkiksi päämäärätietoinen valmentautuminen olympialaisiin voi vaatia lumilautailijalta perinteisten lajikulttuurin arvojen hylkäämistä. Tällöin valmentaja voi tukea urheilijaa hänen henkilökohtaisissa tavoitteissaan, jotka ovat ristiriidassa ehkä jopa urheilijalle läheisen vertaisryhmän kanssa.

Ongelmakeskeisessä oppimisstrategiassa valmentajan tehtävänä on olla tiedon tarjoajan sijasta oppimisen tukija (Hmelo-Silver \& Eberbach 2012), joka tämän tutkimuksen tulosten mukaan varmistaisi lumilautailijalle ennen muuta hyvät harjoitteluolosuhteet ja toimivan vertaisryhmätyöskentelyn. Näin ollen informanttien valmentajalle hyödyllisiksi kokemat managerin tai resurssien hallinnoijan roolit kuuluisivat ongelmakeskeisen oppimisstrategian mukaan ilman muuta valmentajalle. Urheilija-valmentaja-suhteen hierarkiattomuutta vahvistaa lumilautailun kontekstiin sovellettuna se ongelmakeskeisen oppimisstrategian näkemys, ettei valmentajalla ole oikeita vastauksia olemassa, vaan 
valmentajan esittämät kysymykset pyrkivät saamaan oppijassa aikaan hänelle soveltuvien ratkaisujen löytymisen. Valmentaja voi esimerkiksi kysyä lumilautailijalta kysymyksiä hänen tuntemuksistaan tai vastaavasti kehottaa vertaisryhmää keskusteluihin, jolloin urheilija voi itse huomata tarpeen jonkun puuttuvan taidon oppimiselle. Lisäksi valmentaja voi varmistaa urheilijalle sellaiset olosuhteet, joissa urheilija huomaa muita lumilautailijoita havainnoimalla omia epäkohtiaan ja asettaa itselleen uusia tavoitteita.

Hyvät havainnointi- ja suoristusolosuhteet toteutuvat esimerkiksi leirejä järjestämällä tai varmistamalla tiiviin yhteistyön hiihtokeskusten kanssa. Vertaisryhmätyöskentelyn hyödyt olivat Saveryn ja Duffyn (1995) mukaan siinä, että vertaisryhmä mahdollistaa oppijan ideoiden testauksen muiden oppijoiden reaktioita tarkkailemalla. Hyvän vertaisryhmätyöskentelyn organisoidun järjestämisen koimme kuitenkin hankalaksi: vaikka ongelmakeskeisessä oppimisstrategiassa valmentajan tehtäväksi lankeaisi vertaisryhmän suhteiden hallinta siten, että jokainen ryhmän jäsen voisi tuoda oman panoksensa tasapuolisesti näkyville (Savery \& Duffy 1995; Hmelo-Silver \& Eberbach 2012), ei tasavertaisten suhteiden luominen nuorisokulttuurisissa ryhmittymissä ole aivan ongelmaton tehtävä. Nuorisokulttuuriset hierarkiat varmistavat juuri sen, että joidenkin vaikutusmahdollisuudet sosiaalisissa ryhmittymissä ovat paremmat kuin toisten, kuten monista eri suunnista nuorisokulttuureita lähestyneet tutkimukset todistavat (esim. Terpstra 2006; Atencio \& Wright 2009; Bešic \& Kerr 2009).

Tulimme pohdinnoissamme myös siihen päätelmään, ettei yksi kiinteä vertaisryhmä mahdollista nopeasti muuttuvissa nuorisokulttuurisissa lajeissa aina omien ideoiden testaamista parhaalla mahdollisella tavalla. Myös muiden ryhmien mielipiteiden ja reaktioiden havaitseminen voisi olla oppijalle hyödyllistä. Siksi koimme muuttuvaisessa ja trendeille alttiissa lumilautailussa tärkeäksi sen, että lumilautailijat pääsevät harjoittelemaan esimerkiksi leireille, joissa omien taitojen vertaileminen itselle vieraiden lumilautailijoiden taitoihin on mahdollista. Valmentajan tehtävä hierarkisuutta karttavassa lajissa voisi olla siis niiden olosuhteiden varmistaminen, joiden kautta oppija kykenee imemään laaja-alaisesti vaikutteita, ja joiden kautta vertailu muihin lumilautailijoihin mahdollistuu. Tällöin valmentaja ei pyrkisi esittämään lumilautailijalle itse oikeita vastauksia, vaan toisi oppijan siihen ympäristöön, jossa oppija kykenee keksimään vastauksia ja jopa kysymyksiä itse - usein vertaisiinsa tukeutuen.

\subsection{Suomalaisten lumilautailijoiden uran mahdollistava resursointi}

Väitöskirjatyön neljännen osatutkimuksen mukaan suomalaisen ammattilumilautailijan uran maksavat pääosin sponsorit. Lumilautailijan tehtävänä on antaa oikeanlaista näkyvyyttä sponsoreilleen ja sponsorit maksavat siitä palkkaa. Osa palkasta tulee provisioperustaisena suoritusten mukaan. Lisäksi lumilautailijat 
saavat sponsoreiltaan matkabudjetin, joka on usein ensimmäinen sponsorin rahallinen kädenojennus nuorelle lumilautailijalle. Lumilautailijat myös tienaavat kilpailuista sijoituksensa mukaan palkintorahaa, jonka suuruus voi olla jopa useita kymmeniä tuhansia euroja, mutta reilusti vähemmän kuin vaikkapa golfin huipputasolla. Tutkimuksen kaksi urallaan alkuvaiheessa olevaa lumilautailijaa myös mainitsi urheilijatuet itselleen merkittävinä rahoituslähteinä, ja kolme lumilautailijaa totesi liiton leiritykset hyödyllisinä tukina.

Tutkimukseni mukaan lumilautailijoiden sponsorit halusivat lumilautailijan tuovan näkyvyyttä, jonka kautta sponsorin brändi yhdistyy arvostettuihin lumilautailutaitoihin oikeanalaisissa medioissa ja sponsorille tärkeällä markkina-alueella. Sponsorit myös maksoivat lumilautailijalle toimimisesta alakulttuurissa arvostettujen asenteiden mukaisesti. Lumilautailijalle oli tärkeää omata arvostettuihin fyysisiin suorituksiin tarvittavat taidot, mutta yleensä pelkät urheilutaidot tai varsinkaan kilpailumenestys eivät riittäneet takaamaan hyviä sponsorisopimuksia. Sponsoriperusteisen rahoituksen pohjana on siis brändin liittäminen tiettyyn ryhmään ja toimintaan, joiden hienovaraisista merkitysrakenteista lumilautailijat ovat paremmin perillä kuin sponsorit itse.

Mielenkiintoinen sponsorien alakulttuurisia toimintatapoja valottava löydös oli se, että sponsorit varmistivat medianäkyvyytensä antamalla tarvittavat resurssit lumilautailijoiden medianäkyvyyden tuottamiseen. Sponsorit antoivat joko lumilautakuvausten produktioihin suoraan rahaa tai lumilautailija kokosi itse tarvittavan osaamisen ja rahoituksen mediamateriaalin tuottamiseen. Koin näiden rahoitusmallien eron merkittävänä siitä syystä, että ensimmäisessä mallissa raha tulee sponsorilta suoraan mediayhtiölle, kun taas jälkimmäisessä lumilautailija ottaa itse vastuun rahoituksestaan ja produktionsa tuottamisesta. Tämä rahoitusperustan ero oli merkittävä urheilijan vastuun ja vaadittavien taitojen kannalta, kuten myöhemmin tässä koonnissakin ilmenee.

Mikael Lindfeltin (2007; 2010) huippu-urheilukategorioita hyödyntämällä tutkimukseni osoitti, että kilpalumilautailun huipputasolla ylläpidetään sekä kansallisuusaatteeseen nojaavaa FIS:n kilpailukiertuetta ja olympialaisia että täysin kaupallisiin ja kansainvälisiin toimintamalleihin nojaavaa WSF-kiertuetta ja yksittäisiä kutsukilpailuja. Siten lumilautailukilpailuiden huipputaso mukailee kansallisia ja kaupallisia agendoja sekoittaessaan Lindfeltin mallin yleisöhuippu-urheilua. Tulkitsin kuitenkin tutkimuksessani, että huippulumilautailuun on luettava myös lumilautailijoiden arvostamat suoritukset erikoismediassa siitä syystä, että niiden arvostus lumilautailijoiden ja lumilautailua intensiivisesti seuraavan yleisön keskuudessa on niin korkea (ks. Lindfelt 2010). Näiden mediatuotteiden kaupallinen toimintalogiikka ja kansainvälisyys, sekä mediatuotantoihin keskittyvien lumilautailijoiden taloudellinen itsenäisyys, mitkä Lindfelt $(2007 ; 2010)$ tulkitsee ammattilaishuippu-urheilun piirteinä, vahvistavat huippulumilautailun ammattiurheilumaisuutta.

Lindfeltin teoriakehikko ohjasi huomaamaan tutkimuksen keskeisen löydöksen, eli sen rahoitusrakenteen olemassaolon, jonka tulkitsen nuorisokulttuurisille lajeille ominaiseksi internetin aikakaudella: Lumilautailuun oli kehittynyt sellainen tapa olla huipulla, joka ei sopinut mihinkään Lindfeltin esittä- 
mään kategoriaan. Internetin kautta välitettyihin lumilautailun mediatuotantoihin keskittyvät lumilautailijat olivat monesti tuottajia, jotka loivat taitojensa esittelyyn omat areenansa keksimällä sopivat formaatit ja suorituspaikat sekä etsimällä tuotantoon tarvittavat resurssit.

Jos erikoismedia oli aiemmin ottanut vastuun mediatuotannon toteuttamisesta, olivat tutkimuksen lumilautailijat mukautuneet internet-aikakauteen ottamalla yksityisyrittäjämäisen asenteen ja kehittämällä osaamisensa ympärille mediaprojektin. Tämä malli on nimettävissä luovaksi yrittäjyysurheiluksi, jonka määrittelen seuraavasti: urheilija ottaa vastuun sen areenan taloudellisesta tuottamisesta ja teknisestä toteuttamisesta, jossa kykenee esittämään taitojaan lajinsa huipputasolla yleensä eri medioita hyväkseen käyttäen, ja tekee sitä ammatikseen. Urheilun huipputaso näyttää rahoitusperustaltaan luovan yrittäjyysurheilun ja Lindfeltin $(2007 ; 2010)$ kolmen kategorian myötä seuraavalta:

TAULUKKO 2 Urheilun huipputason areenat ja rahoitukselliset perusteet.

\begin{tabular}{|c|c|c|}
\hline & Areenat & $\begin{array}{c}\text { Rahoitukselliset } \\
\text { ominaispiirteet }\end{array}$ \\
\hline $\begin{array}{l}\text { Harrastushuippu- } \\
\text { urheilu }\end{array}$ & $\begin{array}{l}\text { Kansainväliset kilpai- } \\
\text { lut, jotka perustuvat } \\
\text { kansalliselle agendalle. }\end{array}$ & $\begin{array}{c}\text { Eivät omaa vahvaa taloudellista } \\
\text { systeemiä ja mediakiinnostusta. } \\
\rightarrow \text { Ei laajaa ammattilaisur- } \\
\text { heilun järjestelmää. }\end{array}$ \\
\hline $\begin{array}{l}\text { Yleisöhuippu- } \\
\text { urheilu }\end{array}$ & $\begin{array}{c}\text { Kansainväliset kilpai- } \\
\text { lut, joista osa kansalli- } \\
\text { selle ja osa kaupallisel- } \\
\text { le agendalle perustu- } \\
\text { via. }\end{array}$ & $\begin{array}{l}\text { Sekoitus harraste- ja ammatti- } \\
\text { laishuippu-urheilua. }\end{array}$ \\
\hline $\begin{array}{l}\text { Ammattilaishuippu- } \\
\text { urheilu }\end{array}$ & $\begin{array}{l}\text { Kansainväliset kilpai- } \\
\text { lut, jotka perustuvat } \\
\text { kaupalliselle agendalle. }\end{array}$ & $\begin{array}{c}\text { Rakentuu vahvoille sponsoreille } \\
\text { ja laajalle mediakiinnostukselle. } \\
\rightarrow \text { Ammattilaistuminen } \\
\text { mahdollista jo ennen } \\
\text { korkeinta huipputasoa. }\end{array}$ \\
\hline $\begin{array}{l}\text { Luova yrittäjyysur- } \\
\text { heilu }\end{array}$ & $\begin{array}{l}\text { Mediatuotannot, jotka } \\
\text { perustuvat kaupallisel- } \\
\text { le agendalle ja ver- } \\
\text { taisarvioinnille. }\end{array}$ & $\begin{array}{l}\text { Rakentuu urheilijan yksi- } \\
\text { tyisyrittäjämäiselle toiminnalle, } \\
\text { vahvoille sponsoreille ja ala- } \\
\text { kulttuurin sisäiselle viestinnälle. }\end{array}$ \\
\hline
\end{tabular}


Jos harrastushuippu-urheilu, yleisöhuippu-urheilu ja ammattilaishuippuurheilu rakentuvat rahoitukselliselle pohjalle, joka perustuu joko kansalliselle tai kansainväliselle kiinnostukselle ja viestimiselle, ovat luovan yrittäjyysurheilun perusteet alakulttuurin sisällä. Luova yrittäjyysurheilu on siis syntynyt siihen markkinarakoon, joka aiheutuu nuorisokulttuuristen lajien pirstaleisuudesta (Wheaton 2013; Ojala 2014), halusta tuottaa mediamateriaalia sekä myydä tuotteita alakulttuurin sisäisille yleisöille.

Luovan yrittäjyysurheilun nimeäminen urheiluksi esimerkiksi liikkumisen, ruumiillisuuden tai fyysisyyden sijaan liittyy siihen näkemykseen, että myös luovan yrittäjyysurheilun areenat ovat kilpailuun perustuvia. Lumilautailijat kilpailevat huipputasolla toisten lumilautailijoiden kanssa, vaikka areenat ovat mediavälitteisiä, tuotannot lumilautailijoiden itsensä organisoimia, suorituspaikat muuttuvaisia, eivätkä tuomarit määritä voittajia. Luovan yrittäjyysurheilun suoritusten arviointiperusteisiin sekoittuvat oletettavasti kulttuuriteollisuudelle ominaiset toiminnot, kuten tallenteiden taiteelliset edesottamukset. Mutta kuten tutkimuksestani ilmeni, ovat fyysiset suoritukset vertaisarviossa aina keskiössä. Jos taas puhuttaisiin sellaisesta fyysisten suoritteiden muodosta, joka on mediavälitteinen, muttei pyri kilpailemaan fyysisten suoritusten tasossa tietyn urheilulajin sisällä (esim. Duudsonit), voisi toimintaa kuvata paremmin vaikkapa performatiivisen sisällöntuotannon käsite.

Vertaamalla lumilautailun historiaa muiden urheiluhistoriikkien kuvaamiin laji- ja ammattilaistumiskehityksiin tutkimuksessani selvisi, ettei lumilautailu kehittynyt kansallisuuteen nojaavasta toiminnasta kohti kansainvälisyyttä ja amatööriydestä kohti ammattilaisuutta samanlaisin kasvukivuin kuin moni muu laji. Lumilautailussa kiinteät suhteet sponsoreihin ja erikoismediaan rakentuivat varhain ilman herrasmiesmäisyyden menettämisen pelkoa. Samalla tiivis yhteistyö erikoismedian kanssa toi lumilautailua urheilun kentältä lähemmäs kulttuurin kenttää. Vasta Kansainvälisen Olympiakomitean kiinnostuttua lumilautailusta lajiin kehitettiin kansallisiin organisaatioihin nojaavia toimintamalleja ja kilpailuja (Howe 1998). Lumilautailu kehittyi siis monista perinteisistä lajeista poikkeavasti ammattilaishuippu-urheilusta kohti yleisöhuippu-urheilua, eli kansainvälisiltä areenoilta ja kaupallisista agendoista kohti kansallisuuteen nojaavia areenoita ja toimintamalleja.

Neljännen osatutkimukseni perusteella saatoin myös tulkita uuden lumilautailusukupolven sosiaalistumisen kansallisiin toimintamalleihin sen huomion myötä, että uudet lumilautailun sukupolvet olivat valinneet riskittömyyden ja jääneet paikallisille areenoille kansainvälisten sijaan, toisin kuin suomalaisen ammattilumilautailun edeltävä sukupolvi. Kuten Lindfeltin (2010) tutkimukseen nojaamalla saattoi arvailla, voi riskittömänä vaihtoehtoina lumilautailijoille näyttäytyvällä, kansallisiin toimintamalleihin nojaavalla toimintatavalla olla negatiiviset vaikutukset ammattilaisuuteen kiinnittymiselle. Sponsorin markkinointialueen ja lumilautailijan riskinottokyvyn yhteys näytti neljännen osatutkimuksen perusteella tärkeältä lumilautailijan uran rahoituksessa, minkä vuoksi Suomeen ja Eurooppaan jääminen oli sponsorisopimusten kannalta huonompi vaihtoehto kuin Yhdysvaltoihin lähteminen. 
Kulttuurin kentälle ominaiset toimintamallit auttoivat lumilautailijoita omaksumaan Hartleyn (2005a) esittelemiä, kulttuuriteollisuudelle ominaisia, yrittäjyysmalleja. Niissä yritykset mukailevat projekteja ja luovaa osaamista yhdistetään teollisuuden toimintamalleihin, kuten luovan yrittäjyysurheilun kuvauksesta ilmenee. Luovan teollisuuden toimintamallit sopivat tee-se-itseasennetta, luovuutta ja muuntelua arvostavaan lumilautailukulttuuriin.

Saatoin havaita lumilautailun kulttuurihistorioita (Howe 1998; Thorpe \& Wheaton 2011) ja Hartleyn (2005a; 2005b) luovan teollisuuden tutkimuksia hyödyntämällä neljännessä osatutkimuksessani, että luovan yrittäjyysurheilun kehittyminen lumilautailijoiden uria mahdollistavaksi rahoitusrakenteeksi oli sekä alakulttuurin oman toiminnan että internetin kehitykseen nojaavien, teollisuuden rakenteita tukevien, poliittisten ohjelmien aikaansaannosta. Lisäksi yrittäjyysurheilun kehittyminen oli osa sponsorien agendaa, sillä luovan teollisuuden tuotteet perustuvat osallistumiselle ja yksilölliselle kulutukselle (Hartley 2005a), mikä tukee sponsorien markkinointitavoitteita. Totesinkin viimeisessä osajulkaisussani, että luovan yrittäjyysurheilun kehittyminen nuorisokulttuurisiin lajeihin oli itsestään selvä jatkumo huippu-urheilun rahoitusmalleissa internetin aikakaudella.

\subsection{Lumilautailijoiden poikkeavat tavoitteet suhteessa perinteisiin urheilulajeihin}

Viides osatutkimus tarkasteli lumilautailijoiden urheilu-urakertomuksissa näkyviä normeja tavoitteista ja vertasi niitä aiempiin tutkimuksiin moderneissa urheilukultttuureissa vallinneisiin ja vallitseviin tavoitteisiin. Löysimme Hannu Itkosen kanssa tehdyssä osatutkimuksessa kuusi lumilautailijoiden tavoitetta kuvaavaa teemaa: 1) kilpailumenestys, 2) totisuuden haastaminen ironialla, 3) pyrkimys muuttuvaisen urheilukulttuurin esittelyyn mediatuottein, 4) lumilautailusta nauttiminen menestyksestä välittämättä, 5) pyrkimys uravalintojen vapauteen sekä 6) halu olla muiden silmissä ennen muuta "hyvä tyyppi".

Ensimmäiseen teemaan kuuluvissa kommenteissa lumilautailijat ilmaisivat toiveensa kilpailumenestyksestä joko suorasti tai epäsuorasti. Arvostetuimpia kilpailuja olivat suuret kutsukilpailut. Olympialaiset jakoivat mielipiteitä. Osa oli asettanut olympialaisissa pärjäämisen tavoitteekseen. Osalle olympialaiset kuvasivat lumilautailulle vieraita tavoitteita ja toimintatapoja. Tulkitsimme Sahlinin ja Wedlinin (2008) tutkimusta hyödyntäen, että lumilautailijat haastoivat liiallista totisuutta ironian keinoin ja muokkasivat käytäntöjen merkitystä nuorisokulttuuriselle lajilleen sopivampaan muotoon. Toimiessaan modernin yhteiskunnan instituutioiden, kuten koululaitoksen alaisuudessa, lumilautailijat saattoivat vain naureskella käytännöille ilman, että kykenivät muuttamaan todellisuuta haluamaansa suuntaan.

Nauttiminen lumilautailemisesta oli selkeästi tulkittavissa lumilautailijoiden korkeimmaksi päämääräksi. Aineisto sisälsi määrällisesti paljon komment- 
teja, joissa lumilautailemisesta nauttiminen perusteli haastatelluille heidän tekemisiään ja valintojaan. Lumilautailu-uraan liittyvä menestys ei saanut häiritä nauttimista ja nauttiminen teki jopa hengenvaarallisten riskien ottamisesta merkityksellistä.

Lumilautailijoiden tavoitteissa esiintyvä pyrkimys vapauteen kytkeytyi vapauteen ja velvollisuuteen valita omannäköinen tapa olla lumilautailija (ks. myös Hänninen 2007). Tämä teema sisälsi kommentit, joissa lumilautailijat kertoivat haluistaan valita kilpailemisen ja kuvaamisen väliltä. Lisäksi se sisälsi lumilautailijoiden tavoitteet valita oma ilmaisutyylinsä ja itselleen mieluisat suoritusolosuhteet. Paradoksaalisesti normi vapaudesta velvoitti tekemään valintoja, joihin kaikilla ei ollut yhtälaista mahdollisuuta. Valintoja rajoittivat resurssit, jotka määräsivät mahdollisuuksia ottaa osaa kilpailuihin tai kuvauksiin.

Lumilautailijat tavoittelivat myös arvostusta hyvänä jätkänä, mikä tarkoitti arvostusta sosiaalisten taitojen ja ulospäin suuntautuneisuuden vuoksi. Kuten teeman nimi kuvaa, näissä kommenteissa puhuttiin maskuliinisilla määritteillä sosiaalisen kyvykkyyden ihanteista. Holly Thorpen (2011, 139-147) mukaan miehisten käytäntöjen luonnollistuminen on niin lumilautailussa kuin urheilussa yleensäkin hyvin tyypillistä.

Verratessamme löydöksiämme aiempiin tutkimuksiin moderneista urheilukulttuureista huomasimme, että osa lumilautailijoiden tavoitteista oli tulkittavissa modernin urheiluperinteen jatkeena. Lajikulttuurissa arvostettu kilpailumenestys ei poikennut modernista urheilusta. Myös lumilautailijoiden urakertomuksissa esiintyneen erikoistumisen sekä kilpalumilautailuun tähtäävien laskijoiden valmennusjärjestelmän voi tulkita suojelevan modernille urheiluperinteelle ominaisia tavoitteita.

Lumilautailijat liittivät kilpailumenestykseen myös sellaisia merkityksiä, joilla tulkitsimme heidän haastavan modernien urheilukulttuurien tavoitteita. He haastoivat kilpailukäytäntöjen totisuutta esimerkiksi tekemällä pilaa menestyksestään (ks. Prasad 2005, 219-220). Jälkimodernin ajan kulttuuriseen ilmapiiriin tulkitsimme sopivan myös sen, kuinka lumilautailijat sekoittavat liikkumiskäytäntöjä ja mediakäytäntöjä (ks. Seidman 1995, 2). Lumilautailijoiden mediatuotannot rakentuvat epämuodollisesti ja kunkin filmiryhmän näköisesti. Heidän pitää kyetä työstämään identiteettiään ja tekemään valintoja, koska tavoitteita ei ole määrätty ulkoa päin. Epämuodollisessa ympäristössä toimimiseen tarvitaan sosiaalista kyvykkyyttä, jota lumilautailijat arvostivat ja jota he tavoittelivat.

Nuorisokulttuuristen lajien sosialisaatioympäristö on huomattavasti relativistisempi kuin modernien urheilukulttuurien. Ehdotonta suorituskeskeisyyttä ei vaadita, vaan sosiaaliset taidot, nauttiminen ja omannäköinen ura tarjoavat myös hyväksyntää ja onnistumisen kokemuksia. Tulkitsimme, että valinnanvara tavoitteiden keskellä luo myös epävarmuutta normeista, sillä nuorten tulee tulkita muuttuvia ympäristöjä ja ottaa riskejä ilman ulkopuolista ohjausta. Mikko Salasuon ja Anni Ojajärven (2014) tutkimukseen vertaamalla kysyimme, josko nuorisokulttuuristen liikkumismuotojen viehätystä voisi selittää sillä, että 
nuoret saavat asettaa tavoitteita omaehtoisemmin kuin moderneissa urheilukulttuureissa.

\subsection{Löydösten yhteenveto}

Otin väitöskirjatyössäni tutkimusongelmaksi sen, kuinka eri tekijät vaikuttavat suomalaisten freestyle-lumilautailijoiden kiinnittymisessä ammattilaisuuteen. Ensimmäisessä osaongelmassa vastasin tutkimusongelmaan tarkastelemalla lumilautailijoiden sopeutumista ammattilumilautailukentän instituutioihin sen kautta, kuinka lumilautailijat tulkitsevat mahdollisuutensa itseilmaisuun ammattilumilautailukentän lähivuosien muutosten seurauksena. Tutkimukseni paljasti, että ammattilumilautailun kentällä on kaksi alakenttää, jotka tarjoavat lumilautailijoiden tulkintojen mukaan erilaiset mahdollisuudet itseilmaisulle niiden erilaisten organisoitumismuotojen vuoksi.

Lumilautailun mediatuotantojen ympärille muodostuva alakenttä on lumilautakilpailujen alakenttää arvostetumpi sen mahdollistaman vapauden takia. Kilpailun alakentälle erikoistuneet lumilautailijat olivat kiitollisia siitä, että saattoivat toteuttaa rakasta harrastustaan ammattinaan. Kilpailujen vertailevuutta ja äärimmilleen menevää progressiota alleviivaavat kilpailuiden ideologiat kääntyivät lumilautailijoiden näkemyksissä lumilautailun arvoihin paremmin sopiviksi korkeatasoisiksi lumilautailusuorituksiksi ja intohimoksi lumilautailua kohtaan. Lumilautailijat olivat huolissaan lumilautailun säätelystä ja standardisoitumisesta, jonka he kokivat pilaavan mahdollisuutensa itseilmaisuun. Syypäiksi säätelylle he nimesivät usein lumilautailukentän ulkopuoliset urheiluorganisaatiot. Kuvauksen alakenttä rakentui säännösten ja ulkopuolisten asettamien normien sijaan alakulttuurin omille normeille ja jaetulle yhteisymmärrykselle. Tämä organisoitumismalli mahdollisti lumilautailijoiden mielikuvissa vapaamman itseilmaisun. Lumilautailijat olivat kuitenkin huolissaan lumilautailun tason säilymisestä kuvauksen alakentällä, koska toiminnan organisoituminen oli hyvin vapaata.

Toisessa osatutkimuksessa lähdin tarkastelemaan median roolia suomalaislumilautailijoiden urilla, mutta tutkimusongelma laajentui tutkimusprosessin myötä koskemaan median roolia nuorisokulttuurisessa liikkumisessa. Tutkimus paljasti, että valtavirtamedialla, erikoismedialla ja sosiaalisella medialla on jokaisella oma roolinsa nuorisokulttuurisessa liikkumisessa. Valtavirtamedia opettaa lajia suurelle yleisölle, muttei sitä mikä olisi alakulttuurisen pääoman kartuttamisen kannalta oleellista. Erikoismedia tarjoaa nuorisokulttuurisen liikkumisen alakulttuureissa juuri sitä tietoa, joka näyttäytyy autenttisena, ja opettaa alakulttuurista jäsenyyttä nuorison liikkumiskulttuureissa. Erikois- ja verkkomedia tuovat esiin niitä keinoja, joiden avulla lajit pakenevat normittumista. Erikois- ja verkkomedia antaa tilaa ja näkyvyyttä uudenlaisille suoritusympäristöille ja sellaisille suorituksille, jotka eivät urheilukilpailuissa saisi ehkä jalansijaa. Lisäksi verkkomedia sekoittaa liikkumis- ja mediakäytäntöjä yhä enemmän. 
Kolmas osatutkimus selvitti valmentajien roolia lumilautailijoiden kiinnittymisessä ammattilaisuuteen. Tutkimus paljasti valmentajalle neljä roolikategoriaa: 1) Valmentaja on hyödyllinen lumilautailutaitojen oppimiselle; 2) valmentaja on hyödyllinen fysiikkatreenin ja elämänhallintataitojen kannalta; 3) valmentaja on hyödyllinen managerina ja resurssien jakajana; 4) valmentaja on hyödytön. Varsinkin menestyvimmillä mieslumilautailijoilla viimeinen kategoria oli yleisin. Tutkimuksen yksi keskeisistä löydöksistä oli, että lumilautailijat kokevat oppivansa vertaisiltaan enemmän ja paremmin kuin valmentajilta. Merkittävää oli, että ammattilumilautailijat tarvitsevat menestyäkseen myös vertaisten arvostusta, eikä arvostusta saa toimimalla lumilautailukulttuurin arvojen vastaisesti. Tämä arvostus vaikuttaa lumilautailijoiden mahdollisuuteen edetä urallaan niin keskeisesti, että myös valmennuksessa käytettävien oppimisstrategioiden tulisi ottaa lumilautailukulttuurin omaleimaiset arvot huomioon. Kolmas osatutkimus osoitti, että lumilautailijoille ominaiset oppimistavat olivat hyvin samankaltaisia, joita ongelmakeskeisessä oppimisstrategiassa suositaan. Ongelmakeskeinen oppimisstrategia sopisi epähierarkisuudessaan ja oppijakeskeisyydessään hyvin myös lumilautailussa ylläpidettyihin arvoihin.

Neljäs osatutkimus otti kohteekseen ammattilumilautailijoiden rahoitustaustan tarkastelemalla, ketkä lumilautailijoiden uraa rahoittavat, ja millaista uratoimintaa rahoittajat haluavat kehittää ja ylläpitää. Tutkimus vastasi tutkimusongelmaan toteamalla yksiselitteisesti, että suomalaisen ammattilumilautailijan uran maksavat pääosin sponsorit. Lumilautailijoille oli tärkeää omata arvostettuihin fyysisiin suorituksiin tarvittavat taidot, mutta yleensä pelkät urheilutaidot tai varsinkaan kilpailumenestys eivät riittäneet takaamaan ammattilaisuuden mahdollistavaa rahoitusta. Lumilautailijan piti sopia sponsoroivan brändin imagoon ja omata vertaisten arvostusta alakulttuurissa. Lisäksi huomasin sponsorin markkinointialueella ja lumilautailijan riskinottokyvyllä olevan yhteyden rahoituksessa: suomalaisten lumilautailijoiden uuden sukupolven taipumus jäädä Suomeen ja Eurooppaan voi olla uhka lumilautailijoiden rahoitukselle.

Neljäs osatutkimus havaitsi lumilautailukilpailuiden huipputason sopivan Mikael Lindfeltin $(2007,2010)$ huippu-urheilumallin yleisöhuippu-urheilun kategoriaan sekoittaessaan organisoitumisessaan kansallisia ja kaupallisia agendoja. Lumilautailijat olivat myös omaksuneet kilpaurheilusta poikkeavan tavan luoda uraa huipulla mediatuotantojen avulla. Nimesin tavan luovaksi yrittäjyysurheiluksi. Luovassa yrittäjyysurheilussa lumilautailijat hyödyntävät luovalle teollisuudelle tyypillisiä tee-se-itse-identiteettejä ja toimintamalleja, jolloin he itse tuottavat areenat taitojensa näyttämiselle ja hankkivat mediaproduktioihinsa tarvittavan rahoituksen ja osaamisen.

Viides osatutkimus tarkasteli lumilautailijoiden tavoitteita ja vertasi niitä tutkimuksiin modernien urheilukulttuurien tavoitteista sekä jälkimodernin ajan aatevirtauksiin. Koodaamisen ja teemoittelun avulla tulkitsimme lumilautailun sosiaalistumisympäristön sisältävän sisältävän kuusi keskeistä tavoitetta: kilpailumenestykseen pyrkimisen, totisuuden haastamisen ironialla, pyrkimyksen 
muuttuvaisen urheilukulttuurin esittelyyn mediatuottein, tavoitteen lumilautailusta nauttimiseen menestyksestä välittämättä, pyrkimyksen uravalintojen vapauteen sekä halun olla muiden silmissä hyvä tyyppi. Huomasimme kilpailumenestyksen olevan tavoitteena modernin urheiluperinteen jatke. Lumilautailijat pyrkivät kuitenkin hämärtämään kilpailumenestyksen tavoittelun totisuutta ironian keinoin. Lumilautailijoiden tavoitteissa oli myös monia jälkimoderniin aikakauteen sopivia piirteitä, jotka tekivät lumilautailusta sosiaalistumisympäristönä tavoitteiden osalta monipuolisemman kuin moderneista urheilukulttuureista. Lumilautailijat kyseenalaistivat huippu-urheilemisen totisuuden asettamalla nautiskelemisen menestystä tärkeämmäksi tavoitteeksi ja valitsivat omannäköisensä uran valmiiksi määrätyn sijasta. Ainakin kuviteltavissa olevien mahdollisuuksien määrä on moderneihin urheilukulttuureihin verrattuna laajempi, joskin kaikki tavoitteet eivät olleet lumilautailijoille tasa-arvoisesti valittavissa. Olen koonnut osatutkimusteni keskeiset löydökset kuvioon 3.

KUVIO 3 Suomalaisten freestyle-lumilautailijoiden uraa raamittavat asenteet, olosuhteet ja resurssit.

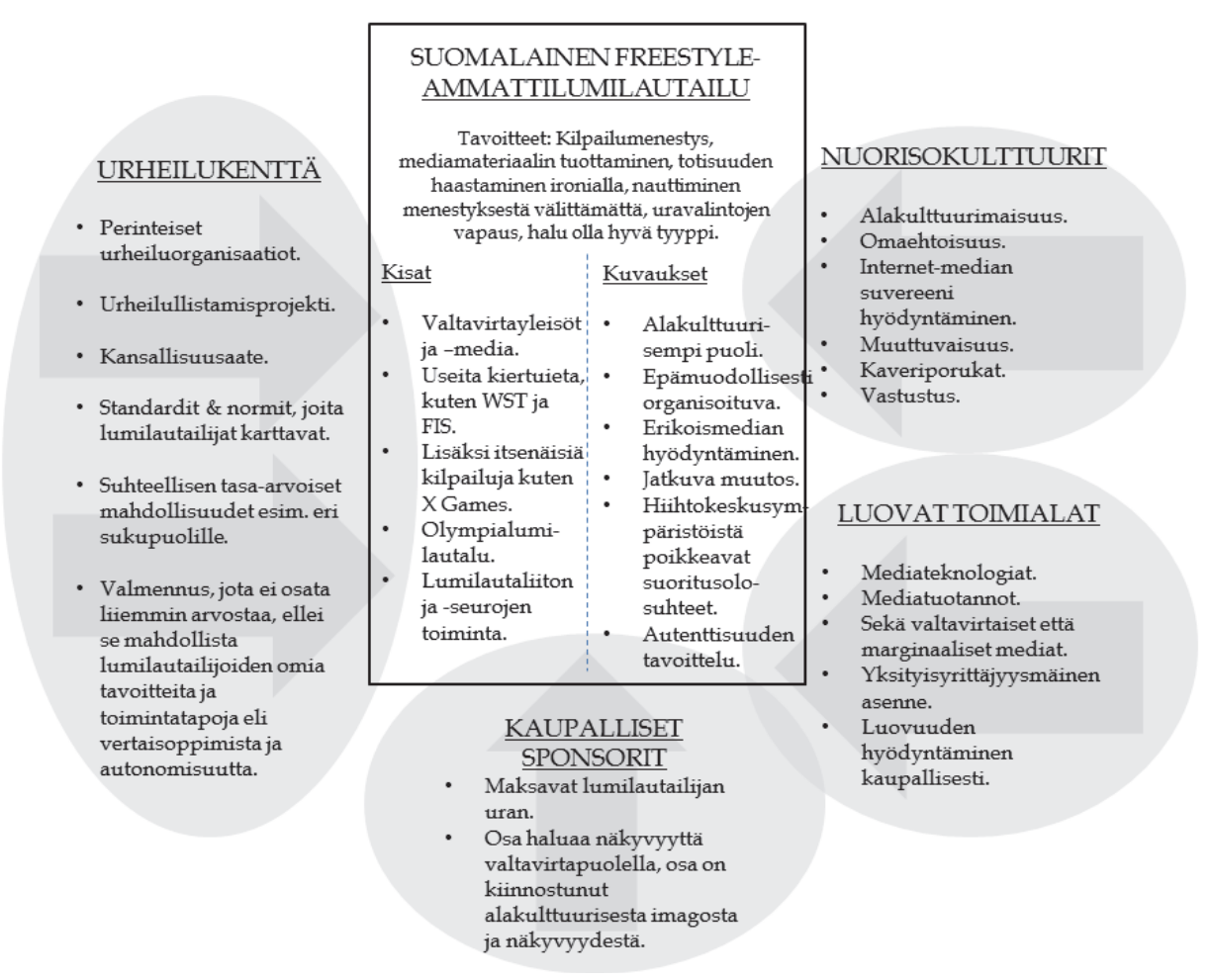

Kuvion keskellä on suomalainen freestyle-lumilautailuun keskittyvä ammattilaiskenttä tavoitteineen ja alakenttineen. Ympärillä olevilta kentiltä omaksutut ja työntyvät vaikutteet tekevät ammattilumilautailusta kentän, jossa on piirteitä urheilusta, kaupallisuudesta, luovista toimialoista ja nuorisokulttuureista. Nämä kaikki vaikutteet yhdessä lumilautailukentän sisäisen toiminnan kanssa 
raamittavat suomalaisten freestyle-lumilautailijoiden uraa määrittäen lumilautailulle ominaisia asenteita, olosuhteita ja resursseja. 


\section{JOHTOPÄÄTÖKSET}

Seuraavat kolme alalukua keskittyvät tutkimukseni merkitykseen akateemiselle tutkimusperinteelle. Neljäs alaluku tarkastelee tutkimuksen löydöksiä mahdollisten käytännön hyötyjen näkökulmasta. Viimeinen alaluku kiteyttää tunnelmani tukimusprosessin päätteeksi.

\subsection{Tutkimuksen anti lumilautailun ja nuorisokulttuurisen liikkumisen tutkimukselle}

Aiemmat nuorisokulttuurista liikkumista tarkastelleet tutkimukset ovat esittäneet lajit fragmentoituneina eli epäyhtenäisinä kokonaisuuksina (Coates, Clayton \& Humberstone 2010; Thorpe \& Wheaton 2011; Thorpe 2011, 28-29; Thorpe 2012a, 78; Snyder 2012; Wheaton 2013, 35). Tutkimukseni vahvistaa näitä huomioita empiirisillä tutkimuslöydöksillä freestyle-lumilautailun kentän kahtiajaosta lajin huipputasolla. Ammattilumilautailun rakenne ei ole muodostunut perinteisten urheilulajien tapaan kilpailujen ympärille, vaan erikoismedian tallenteet ovat mahdollistaneet kehityksen ja taitojen esittelyn perinteisistä urheilulajeista poikkeavilla areenoilla. Lisäksi lumilautailukulttuurissa arvostetut uratavoitteet sallivat perinteisiä urheilulajeja monipuolisemmat urapolut.

Tutkimukseni tuo lisätietoa myös siihen, kuinka hierarkiat muodostuvat nuorisokulttuurisissa lajeissa. Yhdenkin lajin harrastustyylin, kuten tässä tapauksessa freestyle-lumilautailun, sisällä voi olla hyvin hienovaraisia sosiaalisia rakenteita, jotka määrittävät harrastajien statusta alakulttuurin sisällä. Tässä tutkimuksessa mediaproduktioiden alakenttä näyttäytyi arvostetumpana kuin kilpailujen, koska se noudatteli enemmän alakulttuurissa ylläpidettyjä arvoja.

Tutkimus vahvisti myös aiempien tutkimusten (Thorpe 2007; 2011, 27-28) väitteitä lumilautailun valtavirtaistumisesta, mutta myös haastoi niitä. Tutkimukseni mukaan lumilautailijavetoisten kilpailuorganisaatioiden ja niiden järjestämien kilpailujen koetaan monin tavoin samankaltaistuneen perinteisten urheiluorganisaatioiden kanssa. Myös osa lumilautailijoiden tavoitteista on hy- 
vin samankaltaisia perinteisten urheilukulttuurien kanssa. Tämä ei kuitenkaan tarkoita, että ammattilumilautailu olisi kauttaaltaan valtavirtaistunut. Fragmentoituneen lajin harrastajilla ja ammattilaisilla on yhä alakulttuurille ominaisesti keinoja paeta valtavirtaistumista. Jälkimodernille ajalle luontuvat lumilautailijoiden tavoitteet, joissa pyritään totisuuden haastamiseen, omannäköiseen uraan ja nauttimiseen, mahdollistavat valtavirtaistumisen vastustamisen. Lisäksi lumilautailijat pakenevat normitetuista suoritusolosuhteista median avulla alakulttuurin omaan merkitysmaailmaan, jossa autenttisuuden symboliikka ymmärretään.

Nuorisokulttuuristen lajien harjoittajat saattoivat esitellä mediatallenteiden kautta omia taitojaan itse löytämissään suorituspaikoissa ilman virallisia tuomareita, valmiiksi päätettyjä olosuhteita ja televisioinnin tai kilpailuorganisaatioiden määrittämiä aikatauluja. Näin ollen urheilujärjestöillä, mediayhtiöillä ja sponsoreilla ei ole ollut nuorisokulttuuristen lajien viestinnässä samaan tapaan valtaa kuin perinteisessä huippu-urheilussa (ks. Turtiainen 2012, 102). Nuorisokulttuureista puhuttaessa voisi jopa todeta, että media luo nuorille mahdollisuuksia paeta aikuisten maailmaa. Samalla aikuisten maailma valtavirtamedian moraalisine paniikkeineen tarjoaa tarpeellisen peilauspinnan alakulttuurisen identiteetin säilyttämiselle. Verkkomedian myötä liikkumiskäytäntöjen ja median kytkennät ovat yhä vahvistuneet, joskin tämäkään tutkimus ei kyennyt avaamaan kunnolla verkkomedian ja nuorisokulttuurisen liikkumisen kohtaamisia nopeasti muuttuvassa maailmassa. Näin tutkimus yhtyi liikuntasosiologi Brian Wilsonin (2008) näkemykseen lisätutkimuksen tarpeesta verkkomedian ja alakulttuurien yhteistyössä.

Vaikka tutkimuksen löydökset tukivatkin aiempia tutkimuksia urheilun ja nuorisokulttuurisen liikkumisen fragmentoitumisesta ja valtavirtaistumisesta, ei tutkimukseni antanut aihetta tulkita kehityssuuntien lisääntyneen dramaattisesti jonkun tapahtumaketjun seurauksena. Kulttuurisosiologi Angela McRobbien $(1994,28)$ mukaan fragmentoitumiskehitystä ja liikuntasosiologi Michele K. Donnellyn (2008) mukaan valtavirtaistumiskehitystä diagnosoidaan tutkimuksissa jopa liikaa kuitenkaan osoittamatta empiirisesti lähtötilannetta ja tietyn kehityksen lisääntymistä. Tutkimukseni perusteella kilpailullisuutta, ammattilaisuutta, erilaisia harrastustyylejä, vastustusta ja valtavirtaisuutta on ollut lumilautailun alkuvuosista asti. Toki monet lumilautailun piirteet ovat vahvistuneet lajin kasvaessa, mutta esimerkiksi alakulttuurisen median kehitys on ollut valtavaa samaan aikaan, kun perinteisen urheilukulttuurin mukainen kilpailutoiminta on lisääntynyt.

Tutkimukseni toi myös lisätietoa alakulttuurien yhteistyöstä kaupallisten tahojen kanssa. Yhteistyö monien kaupallisten sponsorien kanssa antaa resursseja rakentaa alakulttuurista merkityksenantoa suhteellisen vapaasti, sillä sponsorit ovat myös tästä merkityksenannosta riippuvaisia. Siten kaupallisuus ei ole automaattisesti alakulttuurisuuden vastakohta nuorisokulttuurisessa liikkumisessa, kuten aiemmat tutkimukset (Edwards \& Corte 2010; Wheaton 2013, 37) ovat jo osoittaneet. Näin ollen tutkimukseni sekä tukee että haastaa aiempia tutkimustuloksia nuorisokulttuuristen lajien rakenteista ja kehityksistä. 


\subsection{Löydösten merkitys liikunnan organisoidun toiminnan ja urheiluvalmennuksen tutkimuksille}

Nuorisokulttuurisen liikkumisen omaehtoisuuteen, vapauteen ja hauskuuteen kannustava ilmapiiri tekee perinteisen hierarkkisen organisoitumisen ja yhteistyön urheiluorganisaatioiden kanssa haastavaksi, kuten Kari Steen-Johnsen (2008) tutkimuksessaan toteaa. Haasteita eivät aiheuta vain nuorisokulttuurisen liikkumisen arvot. Tutkimukseni toi ilmi, että suomalaisten lumilautailijoiden yhteistyö kaupallisten toimijoiden ja median kanssa on vankkaa ja alkaa suhteellisen varhain. Lisäksi vertaisilla on merkittävä rooli taitojen opettajina. Lumilautailijoiden urakehitys perustuu siis urheilijan, median, sponsorin ja vertaisten väliselle yhteistyölle, jossa perinteisellä organisoidulla toiminnalla ei ole vankkaa jalansijaa.

Lumilautailu ilmentää tämän tutkimuksen perusteella liikuntasosiologi Hannu Itkosen (1996, 227-229) nimeämän eriytyneen toiminnan kauden piirteitä: lumilautailijat ovat valinneet sellaisen liikunnallisen elämäntavan, johon kuuluu perinteisistä lajeista poikkeavia ja helposti muuttuvia tyylejä ja tavoitteita. Näitä liikkumismuotoja on hankala tavoittaa seuratoiminnan kautta. Tutkimukseni mukaan varsinkin mediatuotantoihin keskittyvät lumilautailijat luovat uraa urheilujärjestelmästä erillään omiin verkostoihinsa ja tavoitteisiinsa nojaten. Näin nuorisokulttuuristen lajien uudenlaiset toimintakulttuurit haastavat perinteisten liikuntajärjestöjen tapoja ja tarpeellisuutta.

Lumilautailijoiden ja seuratoiminnan intressien ja toimintatapojen kohtaamisongelmien vuoksi lumilautailuun ei ole kehittynyt sellaista vahvaa julkisuus-markkinallista seuratyyppiä, jonka Itkonen (1996, 230-234) esittää nykyajan kapitalistiselle yhteiskuntajärjestelmälle ominaiseksi seuratoiminnan kehitysvaiheeksi. Pikemminkin suomalaiselle lumilautailukentälle on syntynyt paljon yksityisiä palveluntuottajia, jotka edistävät lajia harrastajatasolla kaupallisin päämäärin. Nämä yritykset rakentavat hiihtokeskuksiin suoritusolosuhteita, järjestävät kilpailuja ja tapahtumia, tuottavat mediasisältöjä ja pitävät leirejä kaikkea sitä, mikä on perinteisesti ollut seuratoiminnan ydinaluetta. Vahvat siteet sponsoreihin ja arvostetuimpien kilpailujen rakentuminen kaupallisille toimintamalleille vie lumilautailijoita yhä kauemmas seuroista ja liitoista siten, etteivät edes kilpailu-uralle tähtäävät lumilautailijat ole riippuvaisia perinteisistä urheiluorganisaatioista kuin enintään uransa alkuvaiheilla. Kaupallisuudelle rakentuva organisoitumismalli tarkoittaa kuitenkin myös sitä, etteivät yleishyödyllistä tukea tarjoavat seurat ole tasoittamassa niiden urheilijoiden urapolkuja, joille lajiin heittäytyminen on suuri taloudellinen riski (ks. Kahma 2012; Piispa 2013).

Tutkimuksen löydökset osoittivat myös, etteivät nuorisokulttuuristen lajien urheilijat anna helposti valtaa valmentajille omiin fyysisiin suorituksiinsa liittyen. Perinteisesti urheiluvalmennuksessa valmentaja on ollut merkittävä tiedon antaja ja erikoisosaaja (Potrac \& Cassidy 2006; Cassidy, Jones \& Potrac 2009), jonka roolia urheilijan uralla ei ole kyseenalaistettu (Taylor \& Garratt 
2013). Tutkimukseni vahvisti aiempia tuloksia (Humphreys 1996; 1997; 2003; Wheaton 2004; 2013, 29; Booth \& Thorpe 2007) nuorisokulttuuristen lajien pyrkimyksistä omaehtoisuuteen ja vapauteen, jolloin yhteistyö auktoriteettien kanssa on lähtökohtaisesti epäilyttävää. Jos kuitenkin urheilijan ja valmentajan välinen suhde rakentuisi epähierarkkisemmalle ja lajikulttuuria kunnioittavammalle lähestymistavalle, jossa lumilautailijoiden monimuotoisia tavoitteita arvostettaisiin, voisivat nuorisokulttuuristenkin lajien urheilijat kokea hyötyvänsä valmennuksesta. Näin tutkimus vahvisti aiempien tutkimusten (SteenJohnsen 2008; Thorpe 2009a; 2009c; Ronglan 2011) viestiä lajikulttuurin ymmärtämisen ja huomioonottamisen tärkeydestä kaikessa organisoidussa toiminnassa.

Jos ongelmakeskeisen oppimisstrategian hyödyt on ymmärretty valmentajien koulutuksessa (Jones \& Turner 2006; Gilbert, Gallimore \& Trudel 2009; Cushion et al. 2010), antoivat tämän tutkimuksen löydökset ymmärtää, että niiden arvo voi olla merkittävä myös urheilijoiden valmennuksessa. Samoin tutkimus haastoi perinteistä valmentaja-urheilija-ajattelua osoittamalla urheilijoiden hyötyvän suuresti vertaisvalmennuksesta, mitä ei urheilun valmennuskirjallisuudessa ole liiemmin noteerattu.

\subsection{Uusia näkemyksiä urheilun, liikunnan ja liikkumisen käsitteellistämiseen}

Nuorisokulttuurista liikkumista on käsitelty yleensä erillään perinteisestä urheilusta, minkä huomaa jo urheilun ja nuorisokulttuurisen liikkumisen käsitteistä. Kuilu kasvaa siirryttäessä huippu-urheilun tasolle; ellei tarkasteluihin irroteta vain nuorisokulttuurisen urheilun kilpailuihin orientoituneita muotoja tai todeta esimerkiksi lumilautailun siirtyneen kohti perinteisiä urheilulajeja olympialaisten myötä (Thorpe 2007; 2011; Thorpe \& Wheaton 2011). Kuitenkin myös nuorisokulttuuristen lajien mediatuotannot perustuvat epämuodolliseen kilpailemiseen fyysisissä suoritteissa. Mediatuotteita myös arvostetaan lajikulttuureissa. Haastoinkin tutkimuksessani perinteisen tavan ajatella huippu-urheilua ja tarkastelin lumilautailun huipputasoa kokonaisuutena muiden huippuurheilumuotojen rinnalla.

Mikael Lindfeltin (2007; 2010) käsitteet harrastehuippu-urheilu, yleisöhuippuurheilu ja ammattilaishuippu-urheilu, joiden avulla myös sektoritutkimukset (Opetus- ja kulttuuriministeriö 2010) ovat hahmottaneet eri urheilulajien rakenteissa ilmeneviä mahdollisuuksia ja haasteita, saivat tutkimukseni myötä rinnalleen luovan yrittäjyysurheilun käsitteen. Luova yrittäjyysurheilu rakentuu urheilijan yksityisyrittäjämäisen toiminnan, kiinteän sponsoriyhteistyön ja alakulttuurisen viestinnän yhteistyönä. Siten tämä tutkimustulos viestii urheilutuotteen, median ja markkinoiden kiinteästä suhteesta, josta lukuisat urheilututkijat ovat kirjoittaneet aiemmin (esim. Itkonen 1996, 230; Horne 2006, 40-43; Boyle \& Haynes 2009, 17-18). 
Luovan yrittäjyysurheilun käsitteessä kiteytyy urheilun kulttuurinen käänne. Lisäksi käsitteeseen sisältyy näkemys urheilukulttuurin fragmentoitumisesta. Nuorisokulttuurisen liikkumisen luonteva yhteistyö erikois- ja verkkomedian kanssa on mahdollistanut monien eri liikkumistyylien syntymisen ja välittämisen nopeasti laajoille yleisöille. Huomasin tutkimuksessani sponsorien rahoittavan luovan yrittäjyysurheilun ylläpitoa juuri siitä syystä, että ne haluavat profiloitua valtavirran sijasta alakulttuurisina toimijoina ja myydä alakulttuurin kuluttajille. Näin ollen urheilu, media ja markkinat kietoutuvat myös urheilurakenteiden syvemmillä tasoilla, mikä asettaa vaatimuksen erikoismedian vahvemmasta huomioimisesta urheilukenttää hahmottelevissa tutkimuksissa.

Tutkimuksessani esiin nouseva luovien luokkien esiinmarssi huippuurheiluun on tarkoittanut luovan yrittäjyysurheilijan syntymistä, kun huipputason urheilijat ovat ottaneet erikois- ja verkkomedian omien urheilusuoritustensa välityskanaviksi. Tämän kehityskulun alleviivaaminen voi näyttäytyä huippu-urheilututkimuksen perinteen valossa vieraalta. Eihän lumilautailun mediamuodoissa ole edes yhtenäisiä, urheilulle ominaisia sääntöjä, jotka esimerkiksi Mikael Lindfelt (2007; 2010; 2012) esittää urheilulajeja yhdistäviksi tekijöiksi. Tutkimukseni haastoi kuitenkin vanhoja tutkimusnäkökulmia samaan tapaan kuin nuorisokulttuurinen liikkuminen haastaa urheilukenttää. Fyysisten suoritusten tasosta kilpaileminen on yhä uusissa toimintatavoissa keskeistä, mutta tee-se-itse-aktivismiin kannustaen.

Tämän tutkimuksen yksi keskeinen löydös oli huippu-urheilun ja luovan teollisuuden lähentyminen nuorisokulttuurisen liikkumisen huipputasolla. Lumilautailun kaltaiset uudet lajit eivät ole neuvotelleet amatööriyden ja ammattilaisuuden moraalisista perusteista perinteisten lajien tavoin (Ilmanen 2005; 2012). Siten esimerkiksi lumilautailu on kyennyt rakentamaan vapaasti yhteistyötä niin kaupallisten toimijoiden kuin mediankin kanssa omat arvopohjansa huomioiden. Ehkä nuorisokulttuuriset lajit ovat tästä syystä kehittyneet erityisen taitaviksi merkitysten välittäjiksi uusliberalistisessa kapitalismissa. Tämä asetelma nostaa esiin kuitenkin kysymyksen siitä, onko kaikilla nuorilla yhtäläiset mahdollisuudet luokkalähtökohdista, etnisestä taustasta ja sukupuolesta riippumattomaan luovan yrittäjyysurheilun toimijuuteen? Kysymys jää seuraavien tutkimusten selvitettäväksi.

\subsection{Maailma on nuorison (alakulttuurinen) peili}

Muuttuvaisen nuorisokulttuurisen liikkumisen tukeminen on tiedetty haasteeksi liikuntapolitiikassa (ks. esim. Valtion liikuntaneuvosto 2011). Omaehtoisuutta ja nopeaa muutosta henkivät nuorisokulttuurit asettavat jäyhät tukijärjestelmät tilanteisiin, joissa nuorilta saatetaan vaikkapa kieltää liikkuminen heidän spontaanisti etsimissään suorituspaikoissa, mutta mahdollisuutta uuden paikan osoittamiselle ei ole (Itkonen 2012). Tämän tutkimuksen valossa on ymmärrettävä, että järjestelmävastaisuus voi olla myös nuorison liikkumisen 
elinehto: alakulttuurit syntyvät alakulttuurisen toiminnan ja urheilukentän tai yhteiskunnan reagoinnin tuotteena. Aikuisten maailman älähdys kertoo nuorisokulttuurisen liikkumisen harrastajille jostakin erityisestä; omista rajoista, omista säännöistä, omasta identiteetistä.

Alakulttuurien hierarkiajärjestelmät, muuttuvaisuus ja niiden jäsenten tyylittely aiheuttaa nuorisokulttuuristen lajien epäyhtenäisyyttä. Toisin kuin monet urheilulajit, nuorisokulttuurit ovat elettyä kulttuuria, jonka tavoitteita, sääntöjä ja muuttumista eivät rajoita urheilujärjestöt. Jos perinteiset urheilujärjestöt ja valtavirtamedia saattavat määrätä lajin säännöistä lumilautailun kilpailupuolella, on varsinkin mediatuotantoihin perustuva harrastaminen ja ammattilaisuus tiukoista säännöistä vapaata. Nuorisokulttuurinen liikkuminen organisoituu tutkimukseni mukaan vahvasti media-areenoita hyödyntäen omia tavoitteitaan, hienovaraisia normejaan ja yhteistä ymmärrystään noudattaen. Edes paikallisten liikuntaseurojen on vaikea tarjota tälle ryhmälle mitään, mitä he kokisivat tarvitsevansa.

Väitöskirjatyöni haastoi ajattelemaan yhteistyötä nuorisokulttuuristen liikkumismuotojen kanssa laajemmin kuin perinteisenä seuratoimintana tai valmennustukena. Nuorisokulttuuristen lajien omaleimaiset arvot sekä pyrkimys vapauteen ja muutokseen tarvitsee ympärilleen tilaa ja autonomisuutta. Valmennustasolla näitä piirteitä voidaan tukea valitsemalla yhteistyömuotoja, jotka tukevat urheilijan omia tavoitteita, päätösvaltaa, resursointia, epähierarkisuutta, vertaisvalmennusta ja luovuutta. Seura- tai liittotoiminnan tasolla lajituki voi olla resurssien mahdollistamista nuorten omaan toimintaan: seura voi ostaa harrastajien käyttöön mediakalustoa, jota jäsenet voivat käyttää vapaasti; liitto voi varmistaa hyvät suorituspaikat neuvottelemalla hiihtokeskusten kanssa yhteistyöstä; kaupunki voi sallia katujen käytön luoviin liikuntasuorituksiin. Nuorisokulttuurit eivät välttämättä tarvitse muuta kuin sanattoman luvan luoda uutta jo olevista resursseista.

Joskus säätely ja vahva ohjaus voivat olla joillekin harrastajille hyväksi. Tutkimukseni mukaan kaikki harrastajat eivät omaa yhtäläisiä verkostoja, alakulttuurista hyväksyntää tai taustatukea. Esimerkiksi naisten lumilautailusuoritukset eivät saisi välttämättä suurtakaan tunnustusta, jos toiminta olisi alakulttuurin omissa käsissä. Suurten kilpailujärjestäjien säännöstöt naisten ja miesten omista sarjoista ja televisioinneista ovat antaneet myös naislumilautailulle arvoa. Yhtä lailla voidaan olettaa, että jotkut lumilautailijat hyötyisivät, ja jo hyötyvät, aktiivisesta valmennuksesta ja seuratoiminnasta, vaikka nämä näkemykset olivat omassa tutkimusaineistossani harvassa. Organisoidun toiminnan ja poliittisen päätöksenteon haasteena onkin omata herkkyys eri ryhmien tarpeiden havaitsemiselle eri aikoina ja lajikulttuureita kunnioittaen.

Havaitsi tutkimuksessani myös, että lajikulttuurien kunnioittaminen ja paljon urheilukenttää puhuttanut urheilija keskiössä -ajattelumalli vaatii aitoa lajitietämystä ja urheilijoiden kuuntelua. Esimerkiksi lumilautailussa yhteistyö valmentajien kanssa on joillekin urheilijoille normaalia ja fysiikkavalmennus jopa yleistä, mutta suurin osa ei koe hyötyvänsä perinteisestä lajivalmentamisesta millään tavalla. Siten valmentajien mediassa ja urheilukulttuurissa saama 
meriitti ei aseta urheilijaa keskiöön, vaan kielii järjestelmävetoisuudesta. Samoin lajille ohjatut valmennustuet muistuttavat siirtomaapolitiikkaa silloin, jos lumilautailijat toivoisivat valmennuksen sijasta managerointia ja mentorointia, tai jos lumilautailijoiden omat tavoitteet poikkeavat valmennustukien myöntäjien toivomista saavutuksista.

Lajikulttuurin tuntemuksen ja arvostuksen tärkeys johtuu myös lajin fragmentoituneisuudesta. Tutkimukseni mukaan alakulttuuriset mediatuotannot mahdollistavat lumilautailijoille fyysisen ilmaisuvapauden ja lajin arvojen vaalimisen paremmin kuin urheilun arvokilpailut. Ilmaisuvapauden mahdollistaa myös alakulttuurisen imagon haluavilta sponsoreilta tuleva rahoitus, jossa alakulttuurisen viestinnän ja merkityksenannon, eli omaehtoisuuden rajoittaminen olisi typerää. Jos kuitenkin urheilujärjestelmää kehitetään kansallisin päämäärin ja arvokilpailuihin tähdäten, asetetaan urheilija jälleen tavoitteineen sivuun. Keiden päämäärin urheilijauria rakennetaan, jos päämäärät asetetaan lajien ulkopuolelta?

\subsection{Parhaani tein, katsotaan mihin se riittää}

Yksi väitöstutkimus freestyle-lumilautailusta ei avaa tyhjentävästi lumilautailua, eikä varsinkaan nuorisokulttuurista liikkumista. Ei siitäkään syystä, että nuoret ovat lähtökohtaisesti fiksuja: miksi tehdä kuten eilen, jos tänään on jo uusi päivä? Näin ollen nuorisokulttuuriseen liikkumiseen jää yhä paljon tutkittavaa.

Omaehtoisuuden kytkeytyminen seuratoimintarakenteeseen, valmennuskulttuurin muuttuminen, lumilautailijoiden asenteet vaihtoehtoisia pedagogisia lähestymistapoja kohtaan, vertaisvalmennuksen toimivuus laajemmin urheilukulttuurissa, fragmentoituneisuuden mahdollistavat liikunnan ja urheilun tukijärjestelmät, nuorisokulttuurisen liikkumisen merkityksenannon aito nuorisokulttuurisuus, yhdenvertaisen osallistumisen mahdollistaminen nuorisokulttuuristen hierarkioiden keskellä, mediamuotojen hyödyntäminen nuorisokulttuurisissa valtaneuvotteluissa. Nämä ovat vain muutamia esimerkkejä mahdollisista mielenkiintoisista tutkimuskohteista, joiden myötä saisimme lisää tietoa nuoria liikuttavista olosuhteista.

Nuorisokulttuurin, ammattilaisurheilun, huippu-urheilun ja luovan teollisuuden rajapinnoilla tapahtuu tämän tutkimuksen perusteella jatkuvasti niin paljon liikuntasosiologian alalle uutta, että tapaustutkimus yhdestä nuorisokulttuurisesta liikkumismuodosta voi osoittautua toimivaksi työkaluksi avaamaan laajempia käytäntöjä ja yhteiskunnallisia ilmiöitä. Samalla se kehottaa tutkimaan ennakkoluulottomasti lisää. Nuorisokulttuurinen liikkuminen pakottaa poikkitieteelliseen lähestymistapaan, mikä avaa mahdollisuuksia tarkastella liikkumisen ilmiöitä osana suurempaa yhteiskunnallista kertomusta. Ymmärtääkseni lumilautailijoiden valmennusasenteita minun oli otettava etäisyyttä urheilun valmennuskirjallisuuteen ja etsittävä kasvatustieteissä, hoitotieteissä ja hallintotieteissä tutkittuja toimintamalleja. Tarkastellessani lumilautailun rakentumista minun oli luotettava intuitiooni urheiluteorioiden riittämättömyy- 
destä ja tähyiltävä kulttuurintutkimuksen suuntaan. Lähestyessäni ammattilumilautailun rahoitusrakenteita, jouduin soveltamaan ennakkoluulottomasti vanhoja näkemyksiä ja kehittämään uutta. Nuorten kekseliäisyys ajaa avarakatseisuuteen. 


\section{SUMMARY}

This study examined Finnish freestyle snowboarder's access to the field of professional snowboarding with five research questions: How do Finnish snowboarders conform to the institutions of the professional snowboarding field? What is the role of the media in the careers of Finnish snowboarders? What role do coaches play in the careers of Finnish snowboarders? What kind of financing allows for a career in professional snowboarding? What kind of career goals do snowboarders set for themselves? For each research question, there is a corresponding article in the doctoral thesis.

The primary data of the study included semi-structured interviews with 16 professional and 5 semi-professional snowboarders aged between 17 and 31 (19 male, 2 female) and their managers (4 personal managers, 5 sponsors' team managers). The questions dealt with themes as follows: the informant's career background; the development from a hobby into a more serious pursuit; becoming attached to professionalism; job description; profession-related pressures, and learning skills concerning snowboarding and careers. During the research process, I also utilized previous studies of action sports and follow-up questions for the informants. The data was transcribed, coded and themed according to each research question.

The first sub-study outlined the institutionalization process in professional freestyle snowboarding by utilizing the semi-structured interviews of Finnish snowboarders. I used concepts introduced by W. Richard Scott $(2001 ; 2008)$ when outlining the differences between the competition and niche media arenas and examining the institutional elements stressed within each arena. I also examine the possibilities for self-expression allowed by the two arenas.The study addressed how, in the history of snowboarding, the incorporation into the Olympics in particular has allowed the development towards large audiences, and with W. Richard Scott's concepts, towards regulative institutional elements, which again have limited the possibilities for self-expression. However, the side of professional snowboarding which is organized around niche media has, partially due to marketing reasons, emphasized normative and cultural cognitive institutional elements and allowed a freer rein on self-expression. This has presented the latter as more attractive in the pro riders' view. Furthermore, the study proposes that multifaceted struggles over the social and symbolic space in the field have resulted in there being enough room for both lifestyle and sport.

The second sub-study, carried out with Hannu Itkonen, was a secondary study and built upon Sarah Thornton's (1996, 2005 [1995]) views on the media and subculture as it reviewed how scholars have previously examined the role of the media in action sports. Our data included 48 studies, of which one was a report and one a journalistic cultural history. Only four of the studies took internet-assisted media into consideration while other studies paid attention to the mainstream media and niche media. Thornton's (Thornton 1996; 2005 [1995]) views on subcultural capital offered us an apt tool for understanding the roles 
and influences of the media concerning action sports. Our examination revealed that the mass media can diminish the versatile nature of action sports and present action sports as standardized and easily understandable. Conversely, niche media and social media in particular, make it possible to show the sport's development without norms, which is important in order for versatile action sports to develop and stay vital. It seems that the popularity and alternate nature of the ESPN's X games is based on a combination of traditional competition format and the production of high-quality media material. In this case, performances by athletes which serve purposes different to simply winning competitions may also receive media coverage. Moreover, our study showed that social media poses challenges for scholars of action sports, although it allows for a stronger merging and mingling of the media and action sports than was previously possible.

The third sub-study, which I carried out with Holly Thorpe, examined how snowboarders perceive the role of a coach in their careers. At first we utilized the primary data of the study. However, we found necessary to collect more precise data related to coaching, and so we conducted 15 semi-structured interviews with Finnish professional and semi-professional snowboarders dealing with the benefits of coaches. In our study, we found that peers and mentors share not only knowledge which is important concerning career maintenance and enhancing functions, but also knowledge on a more day-to-day level concerning successful performances. We suggested that coaching approaches in action sports should cherish the unique values of action sports and enable successful peer-to-peer learning among snowboarders. These training conditions could be reached, we claim, with the Problem-based learning approach (Savery \& Duffy 1995; Hmelo-Silver \& Eberbach 2012) in which the coach is a facilitator and assistant for reflection who ensures complex but beneficial training surroundings and peer collaboration for the snowboarders. The findings of the study explicated how snowboarders are connected by thousands of hair-thin ties to the sports system. Sports organizations, such as the Finnish snowboarding Association, also have to accept the reality that snowboarders understand themselves to be entrepreneurs of their own lives rather than conforming to traditional coach-athlete relationship (see Siisiäinen 2007).

In the fourth sub-study I examined Finnish snowboarders' career resourcing. The sub-study was built upon the primary data, which I utilized in its entirety. The sub-study found that resources for Finnish professional snowboarders' careers come from commercial sponsors who strive for media coverage and association with valued snowboarding performances, attitudes, and trends.The snowboarders were more aware of the delicate meaning structures of snowboarding than the brands were. I applied Mikael Lindfelt's $(2007 ; 2010)$ findings concerning categories of elite sports to my findings concerning resources. I then set out the aspects in which snowboarding does and doesn't fit Lindfelt's categories with the help of previous studies (Hartley 2005a; 2005b; Ilmanen 2005; 2012). Lindfelt's model led me to notice that a career path in snowboarding may be indeed different to traditional sports. Some snowboarders are cultural pro- 
ducers who gather the necessary knowledge, actors and resources around them and build media productions around their snowboarding skills. Practices typical to cultural industries (Hartley 2005a), in which cultural producers combine their knowledge and skills with creativity and internet technology, have been adapted to professional snowboarding's subfield of media productions. I have named this model of elite athletic career "creative sports entrepreneurship". As a result, this study states that the media is a significant and fundamental part of action sports even - and especially - at their highest level. Furthermore, it also claims that the media should be better taken into account in studies and applications concerning these rather new sporting cultures.

The fifth sub-study, carried out with Hannu Itkonen, examined the dynamic socialization environments of youth sports in modern and postmodern eras. We investigated how goal-related norms snowboarding differ from athletic goals in modern youth sports. The study utilized the snowboarder interviews of the primary data as well as previous studies (e.g. Elias \& Dunning 1971; Dunning 1979; 1999; Itkonen 2003; 2012; Kokkonen 2008) concerning sporting goals in modern sport cultures. Our study indicated that the socialization environments of youth sports have become more diverse due to the norms cherished in action sports. Although snowboarding competitions continue the goal traditions of modern sports, the diversity and versatility of snowboarding styles and the array of goals within the sport allow participants to construct their identities in more creative ways than athletes in modern sports. Moreover, snowboarders avoid the seriousness of modern sports by ironizing the goal and rule orientation of sports also in snowboarding competitions.

The key findings of the study are presented in figure 4 below: 
FIGURE 4. The attitudes, circumstances, and, resources framing the careers of Finnish freestyle snowboarders.

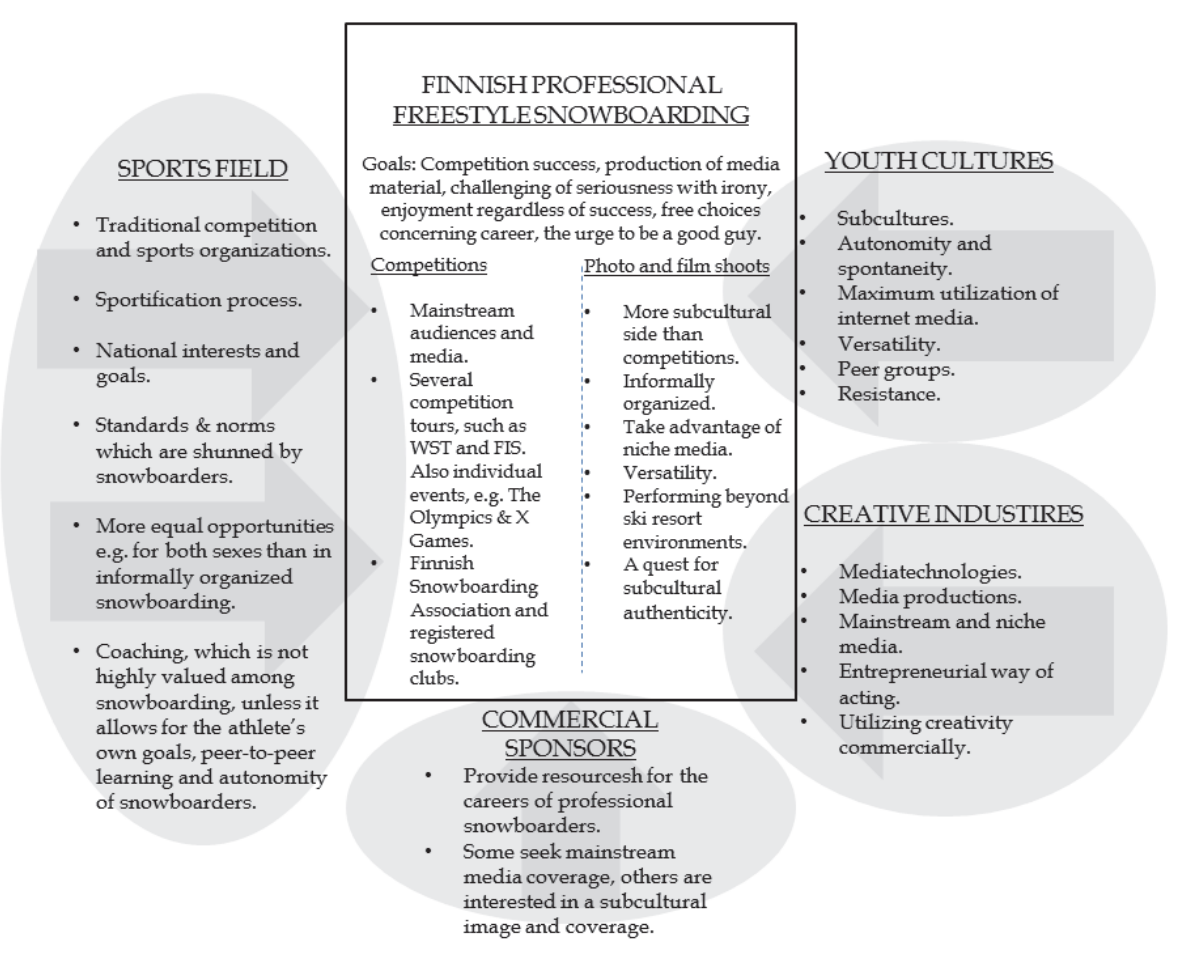

At the centre of the figure is the field of professional snowboarding with its goals and sub-fields. Adopted influences and influences which are intruding from surrounding fields make professional snowboarding a field featuring characteristics from sports, commerce, creative industries and youth cultures. All of these features, together with activity within the field of snowboarding set a framework for the Finnish freestyle snowboarders' career paths, determining the attitudes, circumstances and resources they encounter. 


\section{LÄHTEET}

Aarresola, O. \& Konttinen, N. 2012a. Nuori Urheilija -tutkimus: 14-15vuotiaiden yksilöurheilijoiden harjoittelu, urheilupolut ja mikroympäristö. Jyväskylä: Kilpa- ja huippu-urheilun tutkimuskeskus KIHU. KIHUn julkaisusarja 29.

Aarresola, O. \& Konttinen, N. 2012b. Vanhemmat moni-ilmeinen vaikuttaja kilpaurheiluun sosiaalistumisessa. Liikunta \& Tiede 49 (6), 29-35.

Alapuro, R. 2006. Miten Bourdieu tuli Suomeen. Teoksessa S. Purhonen \& J. P. Roos (toim.) Bourdieu ja minä. Tampere: Vastapaino, 55-69.

Alastalo, M. \& Åkerman, M. 2010. Asiantuntijahaastattelun analyysi: faktojen jäljillä. Teoksessa J. Ruusuvuori, P. Nikander \& M. Hyvärinen (toim.) Haastattelun analyysi. Tampere: Vastapaino, 372-392.

Alfermann, D. \& Stambulova, N. 2007. Career transitions and career termination. Teoksessa G. Tenenbaum \& R. C. Eklund (toim.) Handbook of sport psychology. Hoboken: John Wiley \& Sons, 712-733.

Amis, J. 2005. Interviewing for case study research. Teoksessa D. L. Andrews, D. S. Mason \& M. L. Silk (toim.) Qualitative methods in sports studies. Oxford \& New York: Berg, 104-138.

Andersen, S. S. \& Ronglan, L. T. 2012. Elite sports in Nordic countries: perspectives and challenges. Teoksessa S. S. Andersen \& L. T. Ronglan (toim.) Nordic elite sports: same ambitions - different tracks. Oslo: Universitetsforlaget, 11-24.

Anderson, K. L. 1999. Snowboarding: the construction of gender in an emerging sport. Journal of Sport \& Social Issues 23 (1), 55-79.

Antikainen, A. 1992. Kasvatus, koulutus ja yhteiskunta. Helsinki: WSOY.

Areng, S. \& Willners, M. 1995. Lumilautailu. Porvoo: Werner Söderström.

Aro, R. \& Wilska, T.-A. 2011. Kun mikään ei riitä -vai riittäisikö jo? Hyvinvointikatsaus 13 (1), 80-83.

Atencio, M. \& Wright, J. 2009. 'Ballet it's too whitey': discursive hierarchies of high school dance spaces and the constitution of embodied feminine subjectivities. Gender \& Education 21 (1), 31-46.

Atkinson, M. \& Young, K. 2008. Tribal play: subcultural journeys through sport. Bingley: Jai.

Barker, D., Barker-Ruchti, N., Rynne, S. \& Lee, J. 2014. Moving out of sports: a sociocultural examination of Olympic career transitions. International Journal of Sports Science \& Coaching 9, 255-270.

Barrows, H. S. \& Mitchell, D. L. M. 1975. An innovative course in undergraduate neuroscience experiment in problem-based learning with problem boxes. British Journal of Medical Education 9, 223-230.

Beal, B. 2005. Skateboarding : an alternative to mainstream sports. Teoksessa J. Coakley \& P. Donnelly (toim.) Inside sports. London: Routledge, 133-139.

Bennett, A. 2007. As young as you feel: youth as a discursive construct. Teoksessa P. Hodkinson \& W. Deicke (toim.) Youth cultures: scenes, subcultres and tribes. London: Routledge, 23-36. 
Bennett, A. \& Kahn-Harris, K. 2004. Introduction. Teoksessa A. Bennett \& K. Kahn-Harris (toim.) After subculture: critical studies in contemporary youth culture. New York: Palgrave Macmillan, 1-18.

Bennett, G., Henson, R. K. \& Zhang, J. 2003. Generation Y's perceptions of the action sports industry segment. Journal of Sport Management 17, 95-115.

Bennett, G., Henson, R. \& Zhang, J. 2002. Action sports sponsorship recognition. Sport Marketing Quarterly 11, 174-185.

Bennett, G. \& Lachowetz, T. 2004. Marketing to lifestyles: action sports and generation Y. Sport Marketing Quarterly 13, 239-243.

Bešic, N. \& Kerr, M. 2009. Punks, goths, and other eye-catching peer crowds: do they fulfill a function for shy youths? Journal of Research on Adolescence 19 (1), 113-121.

Beverland, M. B., Farrelly, F. \& Quester, P. G. 2010. Authentic subcultural membership: antecedents and consequences of authenticating acts and authoritative performances. Psychology and Marketing 27, 698-716.

Bloom, G. A., Stevens, D. E. \& Wickwire, T. L. 2003. Expert coaches' perceptions of team building. Journal of Applied Sport Psychology 15 (2), 129-143.

Bourdieu, P. 1984. Distinction: a social critique of the judgement of taste. Cambridge: Harvard University Press.

Bowman, C. L. \& McCormick, S. 2001. Comparison of peer coaching versus traditional supervision effects. The Journal of Educational Research 93, 256-262.

Boyle, R. \& Haynes, R. 2009. Power play: sport, the media and popular culture. 2. painos. Edinburgh: Edinburgh University Press.

Braun, V. \& Clarke, V. 2006. Using thematic analysis in psychology. Qualitative Research in Psychology 3 (2), 77-101.

Breivik, G. 2010. Trends in adventure sports in a post-modern society. Sport in Society 13, 260-273.

Bruce, T. 2010. Using theory to escape the descriptive impasse. Waikato Journal of Education 15 (2), 7-19.

Bryant, S. E. 2005. The impact of peer mentoring in organizational knowledge creation and sharing. Group and organization management. 30, 319-338.

Bryant, S. E. \& Terborg, J. R. 2008. Impact of peer mentor training on creating and sharing organizational knowledge. Journal of Managerial Issues 20, 11-29.

Brymer, E. \& Schweitzer, R. 2013. The search for freedom in extreme sports: a phenomenological exploration. Psychology of Sport \& Exercise 14 (6), 865873.

Butryn, T. M. \& deGarris, L. 2008. Johnny Rodz and the Jade Ring: Larry and Ted's excellent adventure in pro wrestling. Teoksessa M. Atkinson \& K. Young (toim.) Tribal Play : subcultural journeys through sport. Bingley: Jai, 337-351.

Cassidy, T., Jones, R. L. \& Potrac, P. 2009. Understanding sports coaching: the social, cultural and pedagogical foundations of coaching practice. 2. painos. London: Routledge. 
Coates, E., Clayton, B. \& Humberstone, B. 2010. A battle for control: exchanges of power in the subculture of snowboarding. Sport in Society 13, 10821101.

Cohen, A. K. 2005 [1995]. A general theory of subcultures. Teoksessa K. Gelder (toim.) The subcultures reader. 2. painos. Abigdon: Roudledge, 50-59.

Clarke, J., Hall, S., Jefferson, T \& Roberts, B. 2005 [1995]. Subcultures, cultures and class. Teoksessa K. Gelder (toim.) The subcultures reader. 2. painos. Abigdon: Roudledge, 94-104.

Crawford, R. 2007. Media and extreme sport. Teoksessa D. Booth \& H. Thorpe (toim.) Berkshire encyclopedia of extreme sports.Great Barrington: Berkshire, 197-200.

Crosset, T. \& Beal, B. 1997. The use of "subculture" and "subworld" in ethnographic works on sport: a discussion of definitional distinctions. Sociology of Sport Journal 14 (1), 73-85.

Cushion, C. 2006. Mentoring: harnessing the power of experience. Teoksessa R. L. Jones (toim.) The sports coach as educator: re-conceptualising sports coaching. London: Routledge, 128-144.

Cushion, C. J., Armour, K. M. \& Jones, R. L. 2006. Locating the coaching process in practice: models 'for' and 'of' coaching. Physical Education \& Sport Pedagogy 11, 83-99.

Cushion, C., Nelson, L., Armour, K., Lyle, R., Jones, R., Sandfold, R. \& O'Callaghan, C. 2010. Coach Learning and Development: A Review of Literature. January 2010, Sports Coach UK.

Czarniawska, B. \& Joerges, B. 1996. Travels of ideas. Teoksessa B. Czarniawska \& G. Sevón (toim.) Translating organizational change. Berlin: Walter de Gruyter, 13-48.

Czarniawska, B. \& Sevón, G. 1996. Introduction. Teoksessa B. Czarniawska \& G. Sevón (toim.) Translating organizational change. Berlin: Walter de Gruyter, $1-12$.

Denison, J., Mills, J. \& Jones, L. 2013. Effective coaching as a modernist formation: a Foucauldian critique. Teoksessa P. Potrac, W. Gilbert \& J. Denison (toim.) The Routledge handbook of sports coaching. London: Routledge, 388-398.

Denison, J. \& Scott-Thomas, D. 2010. Michel Foucault: power and discourse: the 'loaded' language of coaching. Teoksessa R. L. Jones, P. Potrac, C. Cushion \& L. T. Ronglan (toim.) The sociology of sports coaching. London: Routledge, 27-39.

Denzin, N. K. 2007. Qualitative methodology. Teoksessa C. D. Bryant \& D. L. Peck (toim.) 21st century sociology: a reference handbook. Thousand Oaks: Sage, 88-107.

Di Maggio, P. \& Powell, W. 1983. The iron cage revisited: institutional isomorphism and collective rationality in organizational fields. American Sociological Review 48, 147-160. 
Donnelly, M. K. 2008. Alternative and mainstream: Revisiting the sociological analysis of skateboarding. Teoksessa M. Atkinson \& K. Young (toim.) Tribal play: subcultural journeys through sport. Bingley: Jai, 197-214.

Donnelly, P. 1990. Subcultures in sport: resiliance and transformation. Teoksessa A. G. Ingham \& J. W. Loy (toim.) Sport in social development: Traditions, transitions, and transformations. Champaign: Human Kinetics Publishers, 119-145.

Dunning, E. 1999. Sport matters: sociological studies of sport, violence, and civilization. London: Routledge.

Dunning, E. 1971. The development of modern football. Teoksessa E. Dunning (toim.) The sociology of sport. London: Frank Cass and Company, 133-151.

Edwards, B. \& Corte, U. 2010. Commercialization and lifestyle sport: lessons from 20 years of freestyle BMX in 'Pro-Town, USA'. Sport in Society 13, $1135-1151$.

Elias, N. \& Dunning, E. 1971. Folk football in medieval and early modern Britain. Teoksessa E. Dunning (toim.) The sociology of sport. London: Frank Cass and Company, 116-132.

Eskola, J. \& Suoranta, J. 2003. Johdatus laadulliseen tutkimukseen. 6. painos. Tampere: Vastapaino.

Faulkner, R. R. \& Becker, H. S. 2008. Studying something you are part of: the view from the bandstand. Ethnologie Française 38 (1), 15-21.

Florida, R. L. 2005. The flight of the creative class: the new global competition for talent. New York: HarperBusiness.

Florida, R. 2002. The rise of the creative class: and how it's transforming work, leisure, community and everyday life. New York: Basic Books.

Gadamer, H. 2004. Truth and method. 2. painos. London, New York: Continuum.

Galipeau, J. \& Trudel, P. 2006. Athlete learning in a community of practice : is there a role for the coach? Teoksessa R. L. Jones (toim.) The sports coach as educator: re-conceptualising sports coaching. London: Routledge, 77-94.

Garnham, N. 2005. From cultural to creative industries: an analysis of the implications of the "creative industries" approach to arts and media policy making in the United Kingdom. International Journal of Cultural Policy 11, 15-29.

Gelder, K. 2005. The Field of Subcultural Studies. Teoksessa K. Gelder (toim.) The subcultures reader. 2. painos. Abigdon: Roudledge, 1-15.

Gilbert, W., Gallimore, R. \& Trudel, P. 2009. A learning community approach to coach development in youth sport. Journal of Coaching Education 2, 1-21.

Greenwood, R., Oliver, C., Sahlin, K. \& Suddaby, R. 2008. Introduction. Teoksessa R. Greenwood, C. Oliver, K. Sahlin \& R. Suddaby (toim.) London: Sage, 1-46.

Grove, S. J. \& Dodder, R. A. 1982. Constructing measures to assess perceptions of sport functions: an exploratory investigation. International Journal of Sport Psychology 13 (2), 96-106. 
Guest, G., Bunce, A. \& Johnson, L. 2006. How many interviews are enough?: an experiment with data saturation and variability. Field Methods 18, 59-82.

Haakonsen, T. 2014. Terje Haakonsen: Why I still hate the Olympics. Whitelines Snowboarding Magazine. Viitattu 24.6.2014: http:// whitelines.com/features/comment/terje-haakonsen-why-i-stillhate-the-olympics.html.

Hanton, S., Fletcher, D. \& Coughlan, G. 2005. Stress in elite sport performers: a comparative study of competitive and organizational stressors. Journal of sports sciences 23, 1129-1141.

Hartley, J. 2005a. Creative industries. Teoksessa J. Hartley (toim.) Creative industries. Oxford: Blackwell, 1-40.

Hartley, J. 2005b. Creative identities. Teoksessa J. Hartley (toim.) Creative industries. Oxford: Blackwell, 106-116.

Hasanen, E. 2001. Lumilautailun kulttuurinen merkityksenanto. Jyväskylän yliopisto. Liikunnan sosiaalitieteiden laitos Pro gradu -tutkielma.

Hebdige, D. 1988. Hiding in the light: on images and things. London: Routledge. Hebdige, D. 1979. Subculture: the meaning of style. London: Routledge.

Hetland, A. \& Vitterso, J. 2012. The feelings of extreme risk: exploring emotional quality and variability in skydiving and BASE jumping. Journal of Sport Behavior 35, 154-180.

Hmelo-Silver, C. E. \& Eberbach, C. 2012. Learning theories and problem-based learning. Teoksessa S. Bridges, C. McGrath \& T. Whitehill (toim.) Researching problem-based learning in clinical education: the next generation. New York: Springer, 3-17.

Horne, J. 2006. Sport in consumer culture. Basingstoke: Palgrave Macmillan.

Howe, S. 1998. (Sick): a cultural history of snowboarding. New York: St. Martin's Griffin.

Hubball, H. \& Butler, J. 2006. Learning-centred approaches to games education: Problem-based learning (PBL) in a Canadian youth soccer program. . Journal of Physical Education New Zealand 39, 20-35.

Hubball, H. \& Robertson, S. 2004. Using problem-based learning to enhance team and player development in youth soccer. The Journal of Physical Education, Recreation \& Dance 75 (4), 38-52.

Hufman, J. 2008. 20 years of Mack Dawg Productions - a legacy of influence. Viitattu 27.7.2014: http:// snowboarding.transworld.net/uncategorized/20-years-of-mackdawg-productions/.

Hughson, J. 2008. 'They think it's all over': sport and the end of subculture debate. Teoksessa M. Atkinson \& K. Young (toim.) Tribal play: subcultural journeys through sport. Bingley: Jai, 49-66.

Humphreys, D. 2003. Selling out snowboarding: the alternative response to commercial co-optation. Teoksessa R. Rinehart \& S. Sydnor (toim.) To the extreme: alternative sports, inside and out. New York: State University of New York Press, 407-428. 
Humphreys, D. 1997. 'Shredheads go mainstream'? Snowboarding and alternative youth. International Review for the Sociology of Sport 32, 147160.

Humphreys, D. 1996. Snowboarders: Bodies out of Control and in Conflict. Sporting Traditions 13 (1), 3-23.

Hänninen, R. 2012. Puuterilumen lumo: tutkimus lumilautailukulttuurista. Jyväskylän yliopisto. Jyväskylä studies in humanities 191.

Hänninen, R. 2007. Vapauden merkitys lumilautakulttuurissa. Elore 14 (2), 1-19.

Ilmanen, K. 2012. Urheilun eriytynyt moraaliperusta. Teoksessa H. Ilmanen \& H. Vehmas (toim.) Liikunnan areenat: Yhteiskuntatieteellisiä kirjoituksia liikunnasta ja urheilusta. Jyväskylän Yliopisto, Liikuntatieteiden laitos, Tutkimuksia 1/2012, 175-188.

Ilmanen, K. 2005. Amatööriys urheilun arvoperustana. Teoksessa P. Kauppinen \& A. Nevala (toim.) Liikunnan monet kasvot.Joensuu: Pohjois-Karjalan historiallinen yhdistys, 157-170.

Irwin, G., Hantoon, S. \& Kerwin, D. G. 2004. Reflective practice and the origins of elite coaching knowledge. Reflective Practice 5, 425-442.

Itkonen, H. 2012. Nuorten liikkumisen muuttuvat muodot, tilat ja tavoitteet. Teoksessa K. Ilmanen \& H. Vehmas (toim.) Liikunnan areenat: yhteiskuntatieteellisiä kirjoituksia liikunnasta ja urheilusta. Jyväskylän Yliopisto, Liikuntatieteiden laitos, Tutkimuksia 1/2012, 157-174.

Itkonen, H. 2003. Nuorisourheilun muuttuvat muodot, tilat ja tavoitteet. Teoksessa S. Aapola \& M. Kaarninen (toim.) Nuoruuden vuosisata: suomalaisen nuorison historia. Helsinki: Suomalaisen Kirjallisuuden Seura, 327-434.

Itkonen, H. 1996. Kenttien kutsu: tutkimus liikuntakulttuurin muutoksesta. Helsinki: Gaudeamus.

Jensen, S. Q. 2006. Rethinking subcultural capital. Young 14, 257-276.

Jones, R. L., Harris, R. \& Miles, A. 2009. Mentoring in sports coaching: a review of the literature. Physical Education \& Sport Pedagogy 14 (3), 267-284.

Jones, R. L. \& Turner, P. 2006. Teaching coaches to coach holistically: can problem-based learning (PBL) help? Physical Education \& Sport Pedagogy 11, 181-202.

Jong, M. de, Kamsteeg, F. \& Ybema, S. 2013. Ethnographic strategies for making the familiar strange: struggling with 'distance' and 'immersion' among Moroccan-Dutch students. Journal of Business Anthropology 2, 168-186.

Kahma, N. 2012. Sport and social class: the case of Finland. International Review for the Sociology of Sport 47, 113-130.

Kivinen, O. 2006. Habitukset vai luontumukset? Pragmatistisia näkökulmia bourdieulaisittain objektiiviseen sosiologiatieteeseen. Teoksessa S. Purhonen \& J. P. Roos (toim.) Bourdieu ja minä. Tampere: Vastapaino, 227-265.

Knuuttila, S. 2010. Tutkimusaineistojen muodostaminen. Teoksessa J. Pöysä, H. Järviluoma \& S. Vakimo (toim.) Vaeltavat metodit. Joensuu: Suomen Kansantietouden Tutkijain Seura, 19-42. 
Kokkonen, J. 2013. Liikuntaa hyvinvointivaltiossa: suomalaisen liikuntakulttuurin lähihistoria. Suomen Urheilumuseosäätiön tutkimuksia no 2. Helsinki.

Kokkonen, J. 2008. Kansakunta kilpasilla: urheilu nationalismin kanavana ja lähteenä Suomessa 1900-1952. Helsinki: Suomalaisen Kirjallisuuden Seura.

Koski, P. \& Heikkala, J. 1998. Suomalaisten urheiluorganisaatioiden muutos: lajiliitot professionaalistumisen prosessissa. Jyväskylän yliopisto, Liikunnan sosiaalitieteiden laitos, tutkimuksia no 63/1998.

Kram, K. E. \& Isabella, L. A. 1985. Mentoring alternatives: the role of peer relationships in career development. Academy of Management Journal 28 (1), 110-132.

Kärmeniemi, M., Lämsä, J. \& Savolainen, J. 2013. Aikuisurheilujoiden sosioekonominen asema ja taloudelliset tukijärjestelmät. Kihun julkaisusarja 44. Kilpa- ja huippu-urheilun tutkimuskeskus KIHU.

Ladyshewsky, R. 2006. Peer coaching: a constructivist methodology for enhancing critical thinking in postgraduate business education. Higher Education Research \& Development 25, 67-84.

Laine, L. 1992. Urheilu valtaa mielet. Teoksessa T. Pyykkönen (toim.) Suomi uskoi urheiluun.Helsinki: Liikuntatieteellinen Seura, 101-131.

Lawrence, T. B. 2008. Power, institutions and organizations. Teoksessa R. Greenwood, C. Oliver, K. Sahlin \& R. Suddaby (toim.) The Sage handbook of organizational institutionalism. London: Sage, 170-197.

Lear, J. 2006. Radical hope: ethics in the face of cultural devastation. Cambridge: Harvard University Press.

Liberman, N. 2003. X Games deal part of McDonald's youth kick: fast-food giant riding new extreme-sports sponsorship in bid to reach males in late teens, early 20s. Street \& Smith's Sportsbusiness Journal 6 (3), 3.

Lilja, E. 2013. Lajijuntti ankeuttaa urheilun. Helsingin Sanomat, Pääkirjoitus 29.12.2013.

Lindfelt, M. 2012. Järkeviin odotuksiin - mahdollisiin maaleihin. Liikunta \& Tiede 6 (49), 10-14.

Lindfelt, M. 2010. Elite sports in tension: making identification the core moral norm for professional sports in the future. Sport in Society 13, 186-198.

Lindfelt, M. 2007. Eliten è liten-men växer: förändrade perspektiv på elitidrott. FoU rapport 2007:11. Stockholm.

Lindström, T. 2012. Freestyle-lumilautailun sukupuoli. Lapin yliopisto. Sosiologian laitos. Pro gradu -tutkielma.

Lähteenmaa, J. 1991. Alakulttuuriteoria. Teoksessa T. Hoikkala (toim.) Törmäävät tulkinnat: kirja nuorista ja nuoruudesta. Helsinki: Gaudeamus, 255-263.

Lämsä, J. 2004. Huippu-urheilu pohjoismaissa : Selvitys Suomen, Ruotsin, Norjan ja Tanskan liikuntapolitiikasta, huippu-urheilujärjestelmästä sekä urheilun rahoituksesta. Opetusministeriön työryhmämuistioita ja selvityksiä 2004:21. Helsinki. 
Majors, R. 2001. Cool pose: black masculinity and sports. Teoksessa S. M. Whitehead \& F. J. Barrett (toim.) The masculinities reader. Cambridge: Polity Press, 209-217.

Malinowski, B. 2005 [1922]. Argonauts of the Western Pacific: an account of native enterprise and adventure in the Archipelagoes of Melanesian New Quinea. London: Routledge.

Markula, P. \& Pringle, R. 2006. Foucault, sport and exercise: power, knowledge and transforming the self. New York: Routledge.

Marshall, C. \& Rossman, G. B. 2006. Designing qualitative research. 4. painos. Thousand Oaks: Sage.

Marshall, M. N. 1996. Sampling for qualitative research. Family practice 13, 522-526.

McRobbie, A. 1994. Postmodernism and popular culture. London: Routledge.

McRobbie, A. \& Thornton, S. L. 1995. Rethinking 'moral panic' for multimediated social worlds. British Journal of Sociology 46, 559-574.

Miller, L. 2011. Peer coaching and the perceived impact on fostering positive relationships, knowledge creation and sharing among nursing personnel. Doctoral Dissertations, paper 7, University of San Francisco.

Morgan, K., Jones, R. L., Gilbourne, D. \& Llewellyn, D. 2013. Innovative pedagogies in coach education. Teoksessa P. Potrac, W. Gilbert \& J. Denison (toim.) The Routledge handbook of sports coaching.London: Routledge, 486-496.

Mouzelis, N. P. 2008. Modern and postmodern social theorizing: bridging the divide. Cambridge: Cambridge University Press.

Mäkinen, J. 2010. Urheilun rakenteet ja tuki Suomessa, Ruotsissa ja Norjassa. Kihun julkaisusarja nro 17, Kilpa- ja huippu-urheilun tutkimuskeskus KIHU, Jyväskylä.

Neufeld, V. R. \& Barrows, H. S. 1974. The "McMaster philosophy": An approach to medical education. Journal of Medical Education 49, 10401050.

O'Brien, D. \& Slack, T. 2004. The emergence of a professional logic in English Rugby Union: the role of isomorphic and diffusion processes. Journal of Sport Management 18, 13-39.

O'Brien, D. \& Slack, T. 2003. An analysis of change in an organizational field: the professionalization of English rugby union. Journal of Sport Management 17, 417-448.

Ojala, A. 2014. Institutionalisation in professional freestyle snowboarding Finnish professional riders' perceptions. European Journal for Sport and Society 11, 103-126.

Olson, E. 2012. Mixing Marketing With Social Games and Extreme Sports. New York Times. Viitattu 1.10.2014: http://www.nytimes.com/2012/ 05/04/business/media/degree-men-deodorant-turns-to-videomarketing.html?_r=0. 
Opetus- ja kulttuuriministeriö 2010. "Sanoista teoiksi": Huippuurheilutyöryhmän ajatuksia suomalaisen huippu-urheilun kehittämiseksi. Opetusministeriön työryhmämuistioita ja selvityksiä 2010:12.

Parsons, T. 1951. The social system. London: Routledge \& Kegan Paul.

Patton, M. Q. 2002. Qualitative research \& evaluation methods. 3. painos. Thousand Oaks: Sage.

Piispa, M. 2013. "Vapaasti olen saanut valita eikä mihinkään ole pakotettu": Katsaus suomalaisen huippu-urheilijan elämänkulkuun. Teoksessa M. Piispa \& H. Huhta (toim.) Epätavallisia elämänkulkuja. Huippu-urheilijat ja taiteilijat 2000-luvun Suomessa. Nuorisotutkimusverkosto/Nuorisotutkimusseura, julkaisuja 134, 13-55.

Piispa, M. \& Huhta, H. 2013. Epätavallisia elämänkulkuja: huippu-urheilijat ja taiteilijat 2000-luvun Suomessa. Helsinki: Nuorisotutkimusseura. Nuorisotutkimusverkosto/ Nuorisotutkimusseura, julkaisuja 134.

Popovic, M. L. 2006. From Terje to the Flying Red Tomato: snowboarding's incorporation into the Olympic Games. Teoksessa Cultural imperialism in action. Eight international symposium for Olympic Research.The University of Western Ontario: International Center for Olympic Sports, 157-168.

Portelli, A. 2009. What makes oral history different. Teoksessa L. d. Guidice (toim.) Oral history, oral culture, and Italian Americans.Hampshire: Palgrave Macmillan, 21-30.

Potrac, P. \& Cassidy, T. 2006. The Coach as a 'more capable other'. Teoksessa R. L. Jones (toim.) The sports coach as educator: re-conceptualising sports coaching. London: Routledge, 39-50.

Prasad, A. 2002. The contest over meaning: hermeneutics as an interpretive methodology for understanding texts. Organizational Research Methods 5, 12-33.

Prasad, P. 2005. Crafting qualitative research: working in the postpositivist traditions. Armonk: M.E. Sharpe.

Puuronen, V. 2006. Nuorisotutkimus. Tampere: Vastapaino.

Puuronen, V. 1997. Johdatus nuorisotutkimukseen. Tampere: Vastapaino.

Ray, L. J. \& Sayer, R. A. 1999. Culture and economy after the cultural turn. Thousand Oaks: Sage.

Rinehart, R. E. 2008a. Exploiting a new generation: Corporate branding and the co-option of action sport. Teoksessa M. D. Giardina \& M. K. Donnelly (toim.) Youth culture and sport: Identity power and politics.New York: Routledge, 71-89.

Rinehart, R. E. 2008b. ESPN's X Games: Contests of opposition, resistance, cooption, and negotiation. Teoksessa M. Atkinson \& K. Young (toim.) Tribal Play: subcultural journeys through sport. Bingley: Jai, 175-195.

Rinehart, R. E. \& Sydnor, S. 2003. To the extreme: alternative sports, inside and out. Albany: State University of New York Press.

Robinson, D. W. 1985. Stress seeking: selected behavioral characteristics of elite rock climbers. Journal of Sport Psychology 7, 400-404. 
Ronglan, L. T. 2011. Social interaction in coaching. Teoksessa R. L. Jones, P. Potrac, C. Cushion \& L. T. Ronglan (toim.) The sociology of sports coaching. London: Routledge, 151-165.

Ruddock, A. 2013. Youth and media. Thousand Oaks: Sage.

Ruusuvuori, J., Nikander, P. \& Hyvärinen, M. 2010. Haastattelun analyysin vaiheet. Teoksessa J. Ruusuvuori, P. Nikander \& M. Hyvärinen (toim.) Haastattelun analyysi. Tampere: Vastapaino, 9-34.

Ryba, T. V. \& Stambulova, N. B. 2013. The turn towards a culturally informed approach to career research and assistance in sport psychology. Teoksessa N. B. Stambulova \& T. V. Ryba (toim.) Athletes' careers across cultures. London: Routledge, 1-16.

Sahlin, K. \& Wedlin, L. 2008. Circulating ideas: imitation, translation and editing. Teoksessa R. Greenwood, C. Oliver, K. Sahlin \& R. Suddaby (toim.) The Sage handbook of organizational institutionalism. London: Sage, 218242.

Sahlin-Anderson, K. 1996. Imitating by editing success: the construction of organizational fields. Teoksessa B. Czarniawska \& G. Sevón (toim.) Translating organizational change. Berlin: Walter de Gruyter, 69-92.

Salasuo, M. \& Ojajärvi, A. 2014. Melkein sata vuotta poikien liikkumista elämäntapa ja fyysinen aktiivisuus neljän sukupolven lapsuudessa ja nuoruudessa. Kasvatus \& Aika 8 (1), 98-112.

Savery, J. R. \& Duffy, T. M. 1995. Problem based learning: an instructional model and its constructivist framework. Educational Technology 35 (5), 31-38.

Schulz, W. 2004. Reconstructing mediatization as an analytical concept. European journal of communication 19 (1), 87-101.

Scott, W. R. 2008. Approaching adulthood: the maturing of institutional theory. Theory and Society $37,427-442$.

Scott, W. R. 2001. Institutions and organizations. 2. painos. Thousand Oaks: Sage.

Seidman, I. 2006. Interviewing as qualitative research: a guide for researchers in education and the social sciences. 3. painos. New York: Teachers College Press.

Seidman, S. 1994. Introduction. Teoksessa S. Seidman (toim.) The postmodern turn: new perspectives on social theory. Cambridge: Cambridge University Press, 1-23.

Seiler, S. 2014. Same sitius, altius, fortius ... more women, crashes, and McTwists? International Journal of Sports Physiology \& Performance 9, 122-127.

Sevón, G. 1996. Organizational imitation in identity transformation. Teoksessa B. Czarniawska \& G. Sevón (toim.) Translating organizational change. Berlin: Walter de Gruyter, 49-67.

Siisiäinen, M. 2007. Something old and something new: Finnish Voluntary Associations around the turn of the Millenium. Teoksessa H. Itkonen, A. Salmikangas \& E. McEvoy (toim.) The changing role of public, civic and 
private sectors in sport culture: proceedings of the 3rd EASS conference (European Association for Sociology of Sport) held on 2-5- July in Jyväskylä, Finland. Tutkimuksia / Jyväskylän yliopisto, Liikuntatieteiden laitos, 3/2007, 110-119.

Sisjord, M. K. 2013. Women's snowboarding - some experiences and perceptions of competition. Leisure Studies, 32, 507-523.

Sisjord, M. K. 2009. Fast-girls, babes and the invisible girls. Gender relations in snowboarding. Sport in Society 12, 1299-1316.

Skille, E. A 2011. Change and isomorphism - A case study of translation processes in a Norwegian sport club. Sport Management Review 14, 79-88.

Snyder, G. J. 2012. The city and the subculture career: professional street skateboarding in LA. Ethnography 13, 306-329.

Stambulova, N. B. \& Alfermann, D. 2009. Putting culture into context: cultural and cross-cultural perspectives in career development and transition research and practice. International Journal of Sport \& Exercise Psychology 7, 292-308.

Steen-Johnsen, K. 2008. Networks and the organization of identity: the case of Norwegian snowboarding. European Sport Management Quarterly 8, 337358.

Suomen Lumilautaliitto 2013. Tuloslaskelma, 1.1.2013-31.12.2013.

Suomen Lumilautaliitto s.a. Jäsenseurat. Viitattu 26.5.2014: http://www.fsa.fi/index.php/liitto/jasenseurat/.

Suomen Valmentajat ry 2014. Vuoden 2013 valmentaja Pekka Koskela. Viitattu 8.8.2014: http:/ / www.suomenvalmentajat.fi/?x138327=489598.

Takala, T. 1999. Mitä kasvatussosiologia tutkii? Teoksessa T. Takala (toim.) Kasvatussosiologia. 4.-6. painos. Helsinki: WSOY, 10-17.

Taylor, W. G. \& Garratt, D. 2013. Coaching and professionalisation. Teoksessa P. Potrac, W. Gilbert \& J. Denison (toim.) Routledge handbook of sports coaching. London: Routledge, 27-39.

Terpstra, J. 2006. Youth subculture and social exclusion. Young 14, 83-99.

Thornton, S. 2005 [1995]. The social logic of subcultural capital. Teoksessa K. Gelder (toim.) The Subcultures Reader. 2. painos. London: Routledge, 184192.

Thornton, S. 1996. Club cultures: music, media and subcultural capital. Hanover \& London: Wesleyan University Press.

Thorpe, H. 2012a. Snowboarding: the ultimate guide. Santa Barbara: Greenwood Press.

Thorpe, H. 2012b. 'Sex, drugs and snowboarding': (il)legitimate definitions of taste and lifestyle in a physical youth culture. Leisure Studies 31, 33-51.

Thorpe, H. 2011. Snowboarding bodies in theory and practice. New York: Palgrave Macmillan.

Thorpe, H. 2010. Bourdieu, gender reflexivity, and physical culture: a case of masculinities in the snowboarding field. Journal of Sport \& Social Issues $34,176-214$. 
Thorpe, H. 2009a. The psychology of extreme sport. Teoksessa T. Ryba, R. Schinke \& G. Tenenbaum (toim.) The cultural turn in sport and exercise psychology.Morgantown: Fitness Information Technology, 361-394.

Thorpe, H. 2009b. Bourdieu, feminism and female physical culture: gender reflexivity and the habitus-field complex. Sociology of Sport Journal 26, 491-516.

Thorpe, H. 2009c. Understanding 'alternative' sport experiences: a contextual approach for sport psychology. International Journal of Sport \& Exercise Psychology 7, 359-379.

Thorpe, H. 2008. Foucault, technologies of self, and the media: discourses of femininity in snowboarding culture. Journal of Sport \& Social Issues 32, 199-229.

Thorpe, H. 2007. Snowboarding. Teoksessa D. Booth \& H. Thorpe (toim.) Berkshire encyclopedia of extreme sports. Great Barrington: Berkshire, 286-294.

Thorpe, H. 2006. Beyond "decorative sociology": contextualizing female surf, skate, and snowboarding. Sociology of Sport Journal 23, 205-228.

Thorpe, H. 2005. Jibbing the gender order: females in the snowboarding culture. Sport in Society 8, 76-100.

Thorpe, H. \& Wheaton, B. 2011. 'Generation X Games', action sports and the Olympic movement: understanding the cultural politics of incorporation. Sociology 45, 830-847.

Thrift, N. 1999. Capitalism's Cultural Turn. Teoksessa L. Ray \& A. Sayer (toim.) Culture and economy after the cultural turn. Thousand Oaks: Sage, 135162.

Trudel, P., Gilbert, W. \& Werthner, P. 2010. Coach education effectiveness. Teoksessa J. Lyle \& C. Cushion (toim.) Sport coaching: professionalisation and practice. London: Elsevier, 135-152.

Turner, D. 2013. The civilized skateboarder and the sports funding hegemony: a case study of alternative sport. Sport in Society 16, 1248-1262.

Turrini, J. M. 2013. "Well I don't care about history": oral history and the making of collective memory in punk rock. Notes 70, 59-77.

Turtiainen, R. 2012. Nopeammin, laajemmalle, monipuolisemmin: digitalisoituminen mediaurheilun seuraamisen muutoksessa. Turun Yliopisto, Historian, kulttuurin ja taiteiden tutkimuksen laitos, Kulttuurituotannon ja maisemantutkimuksen julkaisuja 37.

USSA 2012. Bower named olympic coach of year. Viitattu 26.6.2014: http://my.ussa.org/news/bower-named-olympic-coach-year.

Valo, M. 2013. Monografia vai artikkeliväitöskirja? Yliopistopedagogiikka 20 (1), 25-27.

Valtion liikuntaneuvosto 2011. Valtion liikuntaneuvosto 2007-2011: Yhteenveto liikuntaneuvoston ja sen jaostojen toimikaudesta. Valtioneuvosto, Helsinki.

Wagg, S., Brick, C., Wheaton, B. \& Caudewell, J. 2009. Key concepts in sport studies. London: Sage. 
Walker, R. 2002. Bull market. How does a caffeine-loaded energy drink become a billion-dollar brand? Red Bull's creators inject their product with the adrenaline-by-association of extreme sports, and they never stop in the quest for buzz. Outside 27 (4), 72-77.

Wernick, A. 1991. Promotional culture: advertising, ideology and symbolic expression. London: Sage.

Westenholz, A. 2009. Institutional entrepreneurs performing in meaning arenas: transgressing institutional logics in two organizational fields. Teoksessa R. Meyer, K. Sahlin \& M. J. Ventresca (toim.) Institutions and ideology. Bradford: Emerald Group, 283-311.

Wheaton, B. 2013. The cultural politics of lifestyle sports. Abingdon: Routledge.

Wheaton, B. 2004. Introduction: Mapping the lifestyle sport-scape. Teoksessa B. Wheaton (toim.) Understanding lifestyle sports: consumption, identity and difference. London: Routledge, 1-28.

Wheaton, B. \& Beal, B. 2003. 'Keeping it real': subcultural media and the discourses of authenticity in alternative sport. International Review for the Sociology of Sport 38, 155-176.

Wiley, C. G. E., Shaw, S. M. \& Havitz, M. E. 2000. Men's and women's involvement in sports: an examination of the gendered aspects of leisure involvement. Leisure Sciences 22, 19-31.

Wilson, B. 2008. Believe the hype? The impact of the internet on sport-related subcultures. Teoksessa M. Atkinson \& K. Young (toim.) Tribal play: subcultural journeys through sport. Bingley: Jai, 135-152.

Wittlake, S. 2011. Scotty Wittlake Olympics. Viitattu 27.10.2012: http://www.buoloco.com/web6/content/scotty-wittlake-olympics.

Woermann, N. 2012. On the slope is on the screen: prosumption, social media practices, and scopic systems in the freeskiing subculture. American Behavioral Scientist 56, 618-640.

Wolcott, H. 1988. Ethnographic Research in Education. Teoksessa R. M. Jaeger (toim.) Complementary methods for research in education. Washington, DC: American Educational Research Association.

World Snowboard Tour s.a. History. Viitattu 26.6.2014: http://www.worldsnowboardtour.com/history/.

Wylleman, P., Alfermann, D. \& Lavallee, D. 2004. Career transitions in sport: European perspectives. Psychology of Sport \& Exercise 5, 7-20.

Yinger J. M. 1960. Contraculture and subculture. American Sociological Review 25 (5), 625-635.

Young, K. \& Atkinson, M. 2008. Introduction: a subcultural history. Teoksessa M. Atkinson \& K. Young (toim.) Tribal play: Subcultural journeys through sport. Bingley: Jai, 1-46.

Zon, H. van 2013. The unholy alliance of neoliberalism and postmodernism. Vlaams Marxistisch Tijdschrift 47 (2), 110-114.

Zwart, R. C., Wubbles, T., Bergen, T. C. M. \& Bolhuis, S. 2007. Experienced teacher learning within the context of reciprocal peer coaching. Teachers and Teaching: Theory and Practice 13, 165-187. 


\section{LIITTEET}

Liite 1, teemahaastattelut

\section{TEEMAHAASTATTELURUNGOT}

(Kaikkien alkuun taustatiedot: Nimi, tämänhetkiset sponsorit/työpaikka.)

\section{LASKIJOIDEN TEEMAT:}

1) INFORMANTIN URATAUSTA

- Milloin laskeminen alkoi?

- Missä laskeminen alkoi?

- Keiden kanssa?

- Mitä vanhemmat ajattelivat lajivalinnasta?

- Oliko seuratoiminnassa mukana?

- Millaiset harjoitteluolosuhteet olivat?

2) LUMILAUTAILUN KEHITYS HARRASTUKSESTA VAKAVAMMIN OTETTAVAKSI URAKSI/HARJOITTELUKSI

- Milloin kilpailut tai kuvaaminen tulivat mukaan?

- Miten päätyy maailmalle?

- Mitkä ovat lupaavan lumilautailijan tunnuspiirteet?

3) LASKIJAN KIINNITTYMINEN AMMATTILAISUUTEEN

- Milloin ja kuinka saanut esimmäiset sponsorisopimukset?

- Mitkä ovat sponsorisopimusten solmimisessa tärkeitä? (kielitaito, sosiaalisuus?)

- Kuinka suomalaisuus on vaikuttanut uramahdollisuuksiin?

4) INFORMANTIN TYÖNKUVAUS (lumilautailijan kannalta)

- Kilpaileeko vai kuvaako?

- Mitä vaadittavia taitoja oma työnkuva vaatii?

- Kenen intressi kisaaminen tai kuvaaminen on, ja kuka sen mahdollistaa?

- Millaista edustamista sponsorisopimukset vaativat?

- Millaiset tukijoukot ammattilaisuuden taustalla ovat? (managerit? kuka auttaa avaamaan ovia?)

- Millaista treeniohjelmaa noudattaa tällä hetkellä?

- Kuinka näkee lumilautailun kilpailuiden vakavoitumisen?

5) AMMATTILAISUUDEN PAINEET

- Tuleeko kisa- tai kuvaustilanteessa koskaan yritettyä liikaa? (miksi?)

- Kuinka loukkaantumiset ovat vaikuttaneet uraan? 
- Miltä tuntuu laskea ja treenata rinteessä, kun kaikki tunnistavat?

- Kuinka motivaatio on säilynyt ja muuttunut uran aikana?

- Mikä on ollut kuumottavin laskukeikka?

6) LUMILAUTAILU- JA URATAITOJEN OPPIMINEN

- Miten se tietty porukka, jossa olet laskenut, on vaikuttanut laskemiseen?

- Mietitkö temppuja harjotellessa miltä ne näyttävät kuvatessa?

- Mietitkö temppuja harjotellessa, että ne pitää saada kisatilanteessa päälle kerrasta?

- Maskuliinisuuden vaatimus: Jos joku naislaskija osaisi tehdä paremmin jonkun tempun, miltä se tuntuisi?

\section{MANAGERIEN TEEMAT:}

1) INFORMANTIN URATAUSTA

- Millon managerit tulivat mukaan bisnekseen?

- Miten itse tulit mukaan bisnekseen?

3) LASKIJAN KIINNITTYMINEN AMMATTILAISUUTEEN

- Keitä/millaisia laskijoita/ millä perusteella otat laskijoita edustettaviksi?

- Mitkä ovat laskijalle tarpeelliset/toivottavat taidot managerin silmin?

- Mikä hyöty laskijasta on sponsorille?

- Mitä hyötyä/haittaa muista sponsoreista on sponsorille?

- Mikä on markkina-alueen vaikutus laskijan uraan?

- Mistä löydät edustettavat laskijat?

- Mikä on laskijan persoonan vaikutus siihen mihin hän lopulta päätyy (kisoihin vai kuvauksiin vai molempiin)?

4) INFORMANTIN TYÖNKUVAUS

- Mitä teet laskijan hyväksi?

- Keitä edustat?

\section{TEAM MANAGERIEN TEEMAT (JA KYSYMYKSET)}

Samat kuin managereilla, mutta ilman ensimmäistä teemaa.

\section{MAAHANTUOJIEN TEEMAT (JA KYSYMYKSET)}

3) LASKIJAN KIINNITTYMINEN AMMATTILAISUUTEEN 
- Mitä hyötyä laskijasta on maahantuojalle?

4) INFORMANTIN TYÖNKUVAUS

- Mitä teet laskijan hyväksi?

- Keitä edustat?

\section{VALMENTAJIEN TEEMAT (JA KYSYMYKSET)}

2) LUMILAUTAILIJAN KEHITTYMINEN HARRASTELIJASTA VAKAVAMMIN OTETTAVAKSI ROOKIEKSI

- Mikä on laskijan perhetaustan merkitys hänen urallaan?

- Miksi hyviä mieslaskijoita tulee enemmän kuin naislaskijoita?

- Mistä näkee kuka on varteen otettava tulokas?

- Mikä on sopiva ikä erikoistumiselle, ja missä vaiheessa pitäisi kehityksen jo näkyä?

\section{3) LASKIJAN KIINNITTYMINEN AMMATTILAISUUTEEN}

- Millaisia laskijoita otat edustettaviksi maajoukkueeseen?

- Mitkä ovat laskijalle tarpeelliset/toivottavat taidot valmentajan silmin?

- Mistä löydät edustettavat laskijat maajoukkueeseen?

- Mikä on laskijan persoonan vaikutus siihen, mihin hän lopulta päätyy (kisoihin vai kuvauksiin)?

- Millaisia tilanteita liiton sponsorisopimukset aiheuttavat laskijoiden sponsorisopimuksille?

- Kuinka paljon yrität suitsia nuorten urheilijanalkujen alakulttuurisia tapoja?

\section{4) INFORMANTIN TYÖNKUVAUS}

- Mitä teet laskijan hyväksi?

- Mitä hyötyä valmentajasta ja liitosta on yleisesti laskijalle?

\section{LUMILAUTAILUMEDIAN EDUSTAJIEN TEEMAT (JA KYSYMYKSET)}

3) LASKIJAN KIINNITTYMINEN AMMATTILAISUUTEEN

- Keitä/millaisia/ millä perusteella otat laskijoita edustettaviksi lehtenne juttuihin ja kuviin tai leffaanne?

- Mitkä ovat laskijalle tarpeelliset tai toivottavat taidot? 
- Onko laskijan maantieteellisellä alueella merkitystä siihen, miten hän päätyy edustettaviksi lehteenne tai leffaanne? (Mikä on markkina-alueen vaikutus laskijan uraan?)

- Mistä löydät edustettavat laskijat kuviin ja juttuihin tai leffaan?

4) INFORMANTIN TYÖKUVAUS

- Mitä hyötyä lehdessä tai leffassa esiintymisestä on laskijalle? (Mitä teet laskijan hyväksi?)

- Millaiselle kohdeyleisölle teette lehteä tai filmiä? 
Liite 2, valmennuskysymykset

VALMENNUSTUTKIMUKSEN KYSYMYKSET (jatkoa kuudenteen teemaan)

ONKO SINULLA VALMENTAJAA TÄLLÄ HETKELLÄ?

Jos kyllä, niin:

- mikä valmentajan rooli on?

- kuinka usein näette?

- mitä teette yhdessä?

- kuinka valmentaja auttaa treenaamisessa?

OLETKO TEHNYT YHTEISTYÖTÄ VALMENTAJIEN KANSSA ENNEN? Jos kyllä, niin:

- kuinka monen kanssa?

- mitä pidit näiden valmentajien kanssa työskentelystä?

JOS ET TYÖSKENTELE NYT VALMENTAJAN KANSSA, NIIN MIKSI ET?

- Haluaisitko työskennellä valmentajan kanssa?

- Mitä haluaisit valmentajan tekevän kanssasi?

MILLAISIA TAITOJA NÄET ETTÄ VALMENTAJA TARVITSEE TOIMIAKSEEN AMMATTILUMILAUTAILIJOIDEN KANSSA?

MIKÄ ON MIELIKUVASI SIITÄ, MIHIN VALMENTAJIA TARVITAAN LUMILAUTAILUSSA?

- Eroaako se mielestäsi muista urheilulajeista, esim. niistä joita olet harrastanut aiemmin? 
Liite 3. Aineiston koodaus.

A. Näyte koodaamisesta ensimmäisessä osatutkimuksessa.

\begin{tabular}{|c|c|c|}
\hline TEKSTIKOHTA & $\begin{array}{l}\text { INSTITUTION. } \\
\text { ELEM. }\end{array}$ & SEURAUKSET \\
\hline $\begin{array}{l}\text { Mut ne on ne aika, } \\
\text { [naurahtaa] tosi usein on, } \\
\text { vähän liianki usein on } \\
\text { semmoset ty,- niinku } \\
\text { ennalta arvattavat et ne } \\
\text { tietää mitä siel tulee olee. } \\
\text { Seki on yks asia mihin } \\
\text { lumilautailussa pitäis } \\
\text { kiinnittää huomiota nii, } \\
\text { mahollisimman } \\
\text { monipuolisia, niinku } \\
\text { slopestylen juttuja, tai } \\
\text { pipejäki vois vähän } \\
\text { muuttaa, et niinku, se on } \\
\text { just se on vähän sääli et se } \\
\text { on menny sill- siihen niinku, } \\
\text { FISissä varsinki et se pitää } \\
\text { olla joku standardi, mikä on } \\
\text { lumilautailussa sitä sanaa ei } \\
\text { sais ees käyttää et on } \\
\text { standardi mun mielestä. Ja } \\
\text { sit tota ni, TTR:ssäki on } \\
\text { vähän menny siihen että } \\
\text { tehään ne neljä hyppyriä, ni } \\
\text { kaikki voi tehä neljä } \\
\text { tuplakorkkia, et kuka sen } \\
\text { tekee ensimmäisenä, tai } \\
\text { jotaki tämmöstä tiäkkö et } \\
\text { niinku; et on ihan niinku } \\
\text { mun mielestä ihmeell- tai } \\
\text { siis, emmä sano et mä oon } \\
\text { oikeessa et mä ajattelen niin, } \\
\text { mut mun mielestä se ei } \\
\text { pitäis asettaa jotain rajoja } \\
\text { sille, vaan tehä } \\
\text { mahollisimman } \\
\text { monipuolisesti kaikkia } \\
\text { asioita ois paras. }\end{array}$ & Regulatiivinen. & $\begin{array}{l}\text { Lajin } \\
\text { standardisoituminen. } \\
\text { Laskijan vapaus vähenee. } \\
\text { Suuren yleisön } \\
\text { mielenkiinto lisääntyy. }\end{array}$ \\
\hline
\end{tabular}


B. Näyte koodaamisesta kolmannessa osatutkimuksessa.

\begin{tabular}{|l|l|}
\hline \multicolumn{1}{|c|}{ TEKSTIKOHTA } & \multicolumn{1}{|c|}{ VALMENTAJAN HYÖDYT } \\
\hline $\begin{array}{l}\text { Siis ainoo mul ois vaa vähän et mitä } \\
\text { joilleki skideille et niinku et, niinku et } \\
\text { kattoo sit jotain henkistä puolta ja sitä } \\
\text { ehkä sitte et niinku et mitä syö ja sit } \\
\text { muistaa just jotain keskuvartaloo kun- } \\
\text { touttaa ku sitä ei kukaa koskaa tee } \\
\begin{array}{l}\text { [naurua], siis jotain tollasta, ni siihen } \\
\text { se vois, mut itse laskemiseen ni emmä } \\
\text { usko et. }\end{array}\end{array}$ & $\begin{array}{l}\text { Fyödytön valmentaja lumilautailutai- } \\
\text { tojen oppimisessa. }\end{array}$ \\
\hline
\end{tabular}

C. Näyte koodaamisesta neljännessä osatutkimuksessa.

\begin{tabular}{|l|l|}
\hline \multicolumn{1}{|c|}{ TEKSTIKOHTA } & KUKA MAKSAA \\
\hline $\begin{array}{l}\text { Nii on, mä, mä tiesin et mä saan diilei, } \\
\text { ne piti olla, mul oli ehdotukset ja } \\
\text { kaikki alla, sit siin kesti et mä sain vast } \\
\text { marraskuussa diilit, ja mitähän mä } \\
\text { sain faijalta, mä lainasin varmaa }\end{array}$ & Ensimmäinen sponsorisopimus. \\
$\begin{array}{l}\text { seittemän-kaheksan tonnii olin sillee } \\
\text { lainannu, ni sit rupes vähän }\end{array}$ & Isä maksoi ennen sponsoreita. \\
$\begin{array}{l}\text { kuumottaa että tuleeks niit diilejä } \\
\text { ikinä, tiätsä sillee. Faijaki oli sillee et, } \\
\text { mieti nyt et jos sä et saa niit diilei ni }\end{array}$ & \\
\hline $\begin{array}{l}\text { tost tulee aika pitkä kesäduuni sulle } \\
\text { tietsä etee. (nauraa) Mut kyl ne sit tuli }\end{array}$ & \\
\hline $\begin{array}{l}\text { ja sit marraskuussa mä sain maksettuu } \\
\text { ne mutsille ja faijalle, mä sain sit }\end{array}$ & \\
$\begin{array}{l}\text { kaikki kerralla vaa. Kyl ne sillee } \\
\text { ymmärs, mut totta kai siin kestää ku } \\
\text { vähän vääntää, ku totta kai sponsorit } \\
\text { yrittää saada mahollisimman halvalla } \\
\text { ku ekaa vuotta ja sillee et ei mihinkää } \\
\text { ihan älyttömää hintaa et sä joutusit ite } \\
\text { tehä kesäduunii et sä pääsisit ees } \\
\text { kuvaamaa johonki standardille ni. }\end{array}$ & \\
\hline
\end{tabular}


D. Näyte koodien yhdistymisestä teemoiksi viidennessä osatutkimuksessa.

\begin{tabular}{|c|c|c|}
\hline TEKSTIKOHTA & KOODIT & TEEMAT \\
\hline 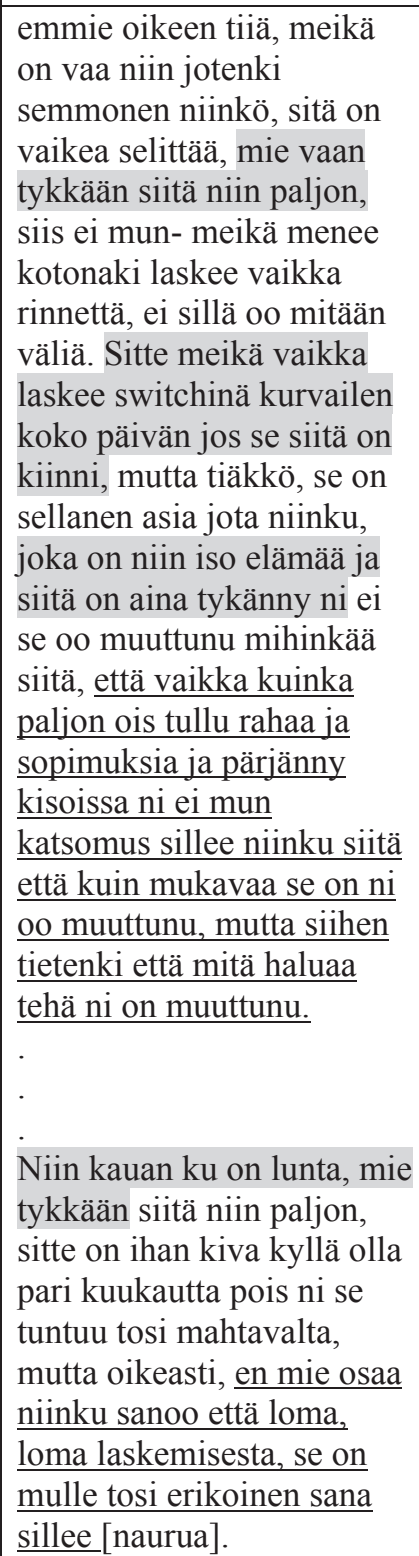 & $\begin{array}{l}\text { Tykkääminen. } \\
\text { (Osoitus tykkäämi- } \\
\text { sestä, että laskee tylsäs- } \\
\text { säkin paikassa vaikka } \\
\text { väärin päin.) } \\
\text { Tykkääminen. }\end{array}$ & $\begin{array}{l}\text { (Tykkääminen \& Sitou- } \\
\text { tuneisuus }>\text { ) } \\
\text { Nauttiminen me- } \\
\text { nestyksestä välittämättä. }\end{array}$ \\
\hline
\end{tabular}




\title{
ORIGINAL PAPERS
}

\begin{abstract}
I
INSTITUTIONALISATION IN PROFESSIONAL FREESTYLE SNOWBOARDING - FINNISH PROFESSIONAL RIDERS' PERCEPTIONS.
\end{abstract}

by

Anna-Liisa Ojala, 2014

European Journal for Sport and Society, 11 (2), 103-126.

Reproduced with kind permission by European Journal for Sport and Society. 


\title{
MEDIAN MERKITYS NUORISOKULTTUURISESSA LIIKKUMISESSA
}

\author{
by
}

Anna-Liisa Ojala \& Hannu Itkonen, 2013

Nuorisotutkimus, 31 (4), 20-35.

Reproduced with kind permission by Nuorisotutkimus. 


\title{
III
}

\section{THE ROLE OF THE COACH IN ACTION SPORTS: USING A PROBLEM-BASED LEARNING APPROACH}

\author{
by
}

Anna-Liisa Ojala \& Holly Thorpe, 2015

International Sport Coaching Journal, 2 (1), 64-71.

Reproduced with kind permission by International Sport Coaching Journal. 


\section{LUOVAN LUOKAN ESIINMARSSI HUIPPU-URHEILUUN : \\ TAPAUSTUTKIMUS SUOMALAISTEN \\ AMMATTILUMILAUTAILIJOIDEN JA HEIDÄN MANAGEREIDENSA \\ NÄKEMYKSISTÄ URHEILU-URAN RESURSOINNISSA}

by

Anna-Liisa Ojala

Submitted to Scientific Journal. 


\section{NAUTINNONHALU VIE VOITONJANON: LUMILAUTAILU JA MUUTTUVAT SOSIALISAATIOYMPÄRISTÖT}

by

Anna-Liisa Ojala \& Hannu Itkonen, (2014)

Kasvatus \& Aika, 8 (4), 7-19.

Reproduced with kind permission by Kasvatus \& Aika. 


\title{
Nautinnonhalu vie voitonjanon: Lumilautailu ja urheilun muuttuvat sosialisaatioympäristöt
}

\author{
Anna-Liisa Ojala ja Hannu Itkonen
}

\begin{abstract}
Urheilun sosiaalistumisympäristöt muodostavat merkittävän kasvualustan suomalaisten nuorten elämässä. Tämä artikkeli paikantaa nuorisourheilun tavoitteita koskevien normien muutoksia kuljettaessa modernista ajasta jälkimoderniin. Tavoitimme lumilautailijoiden haastatteluiden avulla jälkimodernille ajalle sopivia urheiluurien tavoitteita, jotka haastavat moninaisuudessaan modernin totisuuden ja sääntökeskeisyyden, ja jotka tarjoavat omaehtoisemman tulkinnan urheilu-uran onnistumisesta kuin modernit urheilukulttuurit.
\end{abstract}

\section{Johdanto}

Nuorisokulttuurisen liikkumisen käsite on syntynyt tarpeesta ymmärtää nuorille ominaista liikkumista, joka monella tavalla haastaa modernille urheilukulttuurille tyypillisiä ruumiinkulttuureita ja sosialisaatioympäristöjä (esim. Itkonen 2003; Ojala \& Itkonen 2013). Osa nykyajan nuorista rakentaa esimerkiksi lumilautailun, skeittauksen ja parkourin keinoin uudenlaista ruumiinkulttuuria, jossa lähtökohdat urheilemiselle ovat aiemmista sukupolvista poikkeavat. Tästä lähtökohdasta käsin jäljitämme artikkelissamme urheilun muuttuvia sosialisaatioympäristöjä modernista yhteiskunnasta jälkimoderniin siirryttäessä. Rajaamme tutkimuskohdettamme tarkastelemalla lumilautailussa esiintyviä normeja suhteessa modernin ajan urheilukulttuureiden normeihin. Tutkimuskysymykseksemme asetamme sen, kuinka suomalaisten lumilautailijoiden urheilu-urakertomuksissa näkyvät normit urheilijan tavoitteista poikkeavat moderneissa urheilukulttuureissa syntyneistä nuorisourheilulle asetetuista tavoitteista.

Englanninkielisissä tutkimuksissa käytetään nuorisokulttuurisen liikkumisen sijasta käsitteitä action sports, lifestyle sports, extreme sports tai alternative sports (ks. Tomlinson et al. 2005, 2). Suomalaisissa tutkimuksissa liikkumisen nuorisokulttuurisuudella viitataan siihen, etteivät liikkumismuodot ole aikuisten säätelemän urheilu- ja liikuntamaailman imitointia, vaan nuoret aktiivisesti ja jatkuvasti kehittelevät nuorisokulttuuristen liikkumismuotojen tavoitteita, tekniikoita, sääntöjä, suorituspaikkoja ja tyylejä. (Ojala \& Itkonen 2013 , 21.) Näin myös monet merkitykset ja käytännöt, joita nuoriso liittää harrastukseensa, toimivat nuorille liikkumiseen liittyvinä sosialisaatioympäristöinä. Samalla tulkitsemme ajalle ominaisten kisailujen, pelien ja leikkien heijastavan ympäröivää yhteiskuntaa. Totesivathan jo John W. Loy, Barry D. McPherson ja Gerald Kenyon (1978, 242) klassikkotutkimuksessaan kisailuihin ja leikkeihin siirtyvän yhteiskunnille ominaisia käytäntöjä, jolloin kisailut ja leikit opettavat myös lumilautailukulttuurin ulkopuolelta omaksuttuja normeja, rooleja ja kommunikointimalleja. Nuorisokulttuurinen liikkuminen ei kehity erillään muusta yhteiskunnasta. Se on kanssakäymisissä esimerkiksi muiden nuorisokulttuurien, urheilu- 
kentän, markkinoiden ja median kanssa, mikä muuttaa nuorisokulttuuristen liikkumismuotojen rakenteita, merkityksiä ja käytäntöjä.

Analyysimme tarkastelee lumilautailua sosialisaatioympäristönä juuri tavoitteiden kautta siitä syystä, että liikuntatieteissä urheilulajit on nähty perustavanlaatuisesti samankaltaisina ennen muuta normitettujen sääntöjen ja tavoitteiden vuoksi (Lindfelt 2010, 188). Näin ollen lapset ja nuoret sosiaalistuvat tietynlaiseen tapaan asettaa tavoitteita jo varhain osallistuessaan urheiluharrastuksiin. Sosiaalistuessaan tietynlaisiin käytäntöihin lapset ja nuoret sisäistävät myös näkemyksen siitä, milloin he onnistuvat ja milloin epäonnistuvat omilla urheilu-urillaan. Empiiriset havaintomme todistavat nuorisokulttuurisen liikkumisen haastavan perinteisten lajien normilähtökohtia, minkä vuoksi on perusteltua analysoida myös lumilautailijoiden omia tulkintoja osana laajempaa yhteiskunnassa havaittavaa ja samalla muuttuvaa ilmiötä. Urheiluhistoriaan ja historiallisen sosiologian kehyksiin tukeudumme siksi, että koemme sen välttämättömäksi jäljittääksemme nuorten urheilukulttuureita raamittavia normatiivisia muutoksia.

Liikkumisen sosialisaatiota Suomessa on tutkittu aiemmin paikkaan sidottuna ilmiönä (Itkonen 1996; Itkonen \& Simula 2008; Itkonen, Salmikangas \& Simula 2010). Kilpaurheiluun sosiaalistumisessa on keskitytty tarkastelemaan nuorten perheympäristöön liittyviä tekijöitä (Aarresola \& Konttinen 2012). Lisäksi Mikko Salasuon ja Anni Ojajärven (2014) tutkimus fyysisen aktiivisuuden muutoksista eri aikakausien elämäntavoissa on nostettava esiin mainittaessa liikkumisen sosialisaatioympäristöjä koskevia tutkimuksia. He tulkitsivat suomalaisen fyysisen aktiivisuuden muuttuneen sadassa vuodessa agraarin elämäntavan luonnollisesta fyysisyydestä fyysiseen aktiivisuuteen viihdesukupolven kulutusvaihtoehtona (emt). Tässä tutkimuksessa tarkastelemme jotakuinkin saman aikajanan urheilukulttuureita.

Kasvatussosiologi Ari Antikaisen mukaan "sosialisaation ja kulttuurin omaksumisen käsitteet ovat lähes synonyymejä" (1992, 75-76), toisin sanoen yhteiskunta on olemassa sen kulttuurin kautta, jonka yhteiskunnan jäsenet sisäistävät toiminnan ja vuorovaikutuksen myötä. Tässä artikkelissa näkemys sosialisaatiosta kulttuurin omaksumisena on keskeinen. Lisäksi on huomioitava jälkimodernille ajalle ominainen muuttuvuus ja monimutkaisuus, jolloin kulttuuriset ja sosiaaliset valinnat ovat yhä tärkeämpiä nuoren identiteetille (Antikainen 1998, 158). Näillä oletuksilla nuorisokulttuuriset liikkumismuodot näyttäytyvät merkittävänä sosialisaatioympäristönä, jolle altistuminen ja sille ominaisen kulttuurin omaksuminen voi olla myös aktiivinen valinta, joka mahdollistaa nuorelle toivotunkaltaisen identiteetin rakennusaineksia (ks. Giddens 2009, 289). Näin ollen tarkastelemme sosialisaatiota liikkumiskulttuuriin liittyvänä ilmiönä, jossa lajikulttuureissa ylläpidetyt arvot, olosuhteet ja toimintatavat vaikuttavat siihen, millaisia tavoitteita lajien harrastajat omaksuvat ja asettavat itselleen. Tällöin voidaan puhua ryhmän sisällä vallitsevista sosiaalisista normeista. Sisällytämme sosiaalisten normien käsitteeseen kirjoitetut säännöt, sosiaaliset odotukset, oikeudet ja velvollisuudet sekä kulttuurisen yhteisymmärryksen (vrt. Scott 2001, 51-58). On myös oletettavaa, että liikkumiskulttuurin toimijat luovat aktiivisesti uutta omilla teoillaan: he omaksuvat asioita omintakeisesti ja valikoiden, minkä vuoksi kulttuurit ovat jatkuvassa muutoksen tilassa (Sahlin \& Wedlin 2008, 225).

Esittelemme urheilun tavoitteiden kehittymistä osana laajempaa modernien urheilukulttuurien normittumista. Urheilulajien sääntöjen vakiintuminen vaikutti myös urheilukulttuurien sisälle syntyneisiin tavoitteita koskeneisiin normeihin. Urheilukulttuureista puhumme monikossa kautta artikkelin, jotta välttäisimme oletuksen eri urheilulajien perinteiden, käytäntöjen ja arvojen samankaltaisuudesta. Aloitamme esittelemällä käsitekehikkomme ja aineistomme, josta jatkamme tutkimuskontekstin eli lumilautailun historian tarkasteluun. 
Sen jälkeen esittelemme teemoittelumme ja tarkastelemme modernia urheilukulttuuria haastavia löydöksiämme suhteessa jälkimodernia aikaa määrittäviin piirteisiin.

\section{Keskeiset käsitteet ja tutkimusaineisto}

Lumilautailua modernin urheilukulttuurin osana on mahdollista jäsentää modernin ja jälkimodernin käsitteillä. Suomalaisessa viitekehyksessä olisi perusteltua käyttää myös teollisuusyhteiskunnan ja palveluyhteiskunnan jakoa, sillä kiinnittyminen työhön on määrittänyt myös urheilukulttuurien kehittymistä Suomessa (ks. Raiskio 2005). Modernin ja jälkimodernin ajan ideologiset suuntaukset ovat edistäneet urheilukulttuurien normien kehittymistä, minkä vuoksi analyysissä on päädytty hyödyntämään juuri tätä käsitteistöä.

Moderni aika nojaa valistuksen ideologioihin, jotka kannustivat ihmisiä pyrkimään rationaalisuuteen ja tarttumaan uusiin haasteisiin (Prasad 2005, 215; Seidman 1994, 4). Teollistuminen 1800-luvulla oli näiden ideologioiden lapsi, kuten myös modernit urheilukulttuurit. Modernilla ajalla koulutus, uskonto, terveydenhuolto, hallinto, perhe ja urheilu eriytyivät omiksi yhteiskunnallisiksi alueikseen (Prasad 2005, 215). Urheilussa alettiin vakiinnuttaa pelien sääntöjä ja peliolosuhteita sekä perustaa urheiluorganisaatioita valvomaan niitä (Dunning 1999, 53-54; 61-64). Suomessa oli esimerkiksi jo 1920-1930 -luvuilla yli tuhat urheilun keskusjärjestöihin kuulunutta seuraa (Itkonen 2003, 333). Lajien sääntöjä kehiteltiin niin selkeiksi ja tunnetuiksi, että ne tukivat urheilun tavoitteita selvittää yksilöiden, joukkueiden ja maiden välisiä paremmuuksia pelien voittamisen ja häviämisen avulla (ks. Dunning 1999, 71-72). Modernin ajan tunnusmerkiksi ja samalla kansakunnan rakentamiseen tarvittavaan yhdenmukaistamiseen urheiluun liittyvät arvot sopivat hyvin (Kokkonen 2008, 45, 56-70). Lasten ja nuorten urheilemisessa modernin ajan ihanteet ja niitä seuraavat käytännöt johtivat 1900-luvun puolivälistä alkaen erillisiin ikäkausijärjestelmiin ja kilpailusarjoihin (Itkonen 2003, 331-334). Nuorisourheilusta muodostui sosiaalistumisympäristönä yhä järjestelmällisempi ja kauaskatseisempi. Taitoja mitattiin ja tavoitteita asetettiin systemaattisesti kehitysvaiheeseen suhteuttaen. Toki aiempiinkin kisailuihin liittyi keskinäistä kilpailua, mutta ennätystulosten kirjaaminen ja kauaskantoisten urheilutavoitteiden asettaminen oli mielekästä vasta sen jälkeen, kun lajit ymmärrettiin samanlaisina tilanteesta riippumatta.

Vaikka suuri osa maailman maista elää vielä vahvasti modernia aikaa, ovat länsimaat jo useiden yhteiskuntatieteilijöiden mukaan siirtyneet jälkimoderniin aikakauteen (esim. Bauman 1996). Yleensä tutkimusteksteissä jälkimoderniin aikaan viitataan myös postmodernin, myöhäismodernin tai refleksiivisen modernin käsitteillä (ks. lisää esim. Mouzelis 2008). Käytämme tässä tutkimuksessa jälkimodernin käsitettä siksi, että se on mielestämme vakiintunut suomalaisen liikuntatieteen tutkimuskäsitteistöön paremmin kuin postmoderni, myöhäismoderni tai refleksiivinen moderni (ks. esim. Itkonen 2012, 170-171).

Joidenkin tutkijoiden mielestä jälkimoderni aika tarkoittaa vain kiihtynyttä modernin kehitystä (esim. Mouzelis 2008, 1-2), mutta tässä artikkelissa termillä viitataan modernin ajan rinnalla eläviin ideologisiin tapoihin haastaa modernia aikaa. Vaikka aikakauteen viittaavan jälkimodernin ja filosofisiin näkemyksiin viittaavan postmodernismin käsitteet on pyritty pitämään erossa, ovat niiden sisällöt usein sekoittuneet, kuten Stephen Waggin ja kumppaneiden (2009 174-180) liikuntasosiologisessa käsiteselvityksessä. Jälkimodernin ajan irtiotot modernista näkyvät muun muassa populaarikulttuurin ja taiteen sekä niiden sisäisten eri tyylisuuntien rajojen hämärtymisessä. Samoin totisuus ja elitismipyrkimykset ovat korvautuneet hauskanpidolla ja ironialla varsinkin kulttuurituotannoissa. Silti keskeisiä modernin ajan ideologioita, kuten demokratiaa ja suvaitsevaisuutta arvostetaan yhä. 
(Prasad 2005, 219-220; Seidman 1994, 2-4.) Lisäksi modernissa ajassa erillisiksi aloikseen ja alueikseen eriytyneet yhteiskunnan osaset ovat Seidmanin $(1994,2)$ mukaan jälkimodernilla ajalla sekoittuneet. Tämä kehitys tarkoittaa sitä, että esimerkiksi vapaa-aikaa ja työtä on jälleen hankala erottaa toisistaan, tai että median ja urheilun rajat hämärtyvät ihmisten esitellessä urheilusuorituksiaan internetissä.

Etsimme vastauksia tutkimuskysymykseemme teemoittelemalla haastatteluaineistoamme ja peilaten löytyneitä teemoja aiempiin tutkimuksiin modernin ajan nuorisourheilun tavoitteista sekä jälkimodernille ajalle ominaisista aatteellisista virtauksista. Aatteilla tarkoitamme tässä ihmisten suhtautumista ympäröivään maailmaan. Tutkimusasetelmaa puoltaa se, että perinteiset urheilulajit tulkitaan tutkimuksissa modernille ajalle tyypillisinä ruumiinkulttuureina (Itkonen 2012, 171), kun taas nuorisokulttuuristen lajien on tulkittu tarjoavan keinoja jälkimodernille ajalle tyypillisiin identiteetin ja riskinhallinnan pyrkimyksiin (Wheaton 2013, 4-5). Nuorisourheilua tarkastellessamme jätämme sinällään merkittävän harrasteliikunnan huomiotta. Nuorisourheilulla viittaamme tavoitteellisempaan harrastamiseen, jossa harrastamisen intensiteetti on vahvempi.

Haastatteluaineistomme koostuu marraskuun 2010 ja helmikuun 2012 välillä Skiexpomessuilla, epävirallisilla maajoukkueleireillä sekä lumilautailutapahtumissa Suomessa ja Oslon maailmanmestaruuskilpailuissa kerätyistä teemahaastatteluista. Haastatteluissa käsitellään suomalaisen ammattilumilautailijan uraa aloittelijasta ammattilaiseksi. Haastateltavat valittiin lumipallometodia käyttämällä, eli edelliset haastateltavat suosittelivat sellaisia haastateltavia, joilla olisi hyvää tietoa suomalaisen lumilautailijan urasta. Haastatelluista 16 oli haastattelujen tekoaikaan ammattilaisia ja viisi puoliammattilaisia (19 miestä ja 2 naista); iältään 17-31 -vuotiaita. Haastattelut kestivät puolesta tunnista tuntiin. Kaikkien 21 lumilautailijan haastattelut nauhoitettiin ja litteroitiin. Kolmeen haastatteluun osallistui kaksi toisensa hyvin tuntevaa lumilautailijaa samanaikaisesti. Haastatteluista kolme tehtiin puhelimitse pitkien välimatkojen tai aikatauluongelmien vuoksi. Haastattelujen teemat kohdistuivat suomalaisen lumilautailijan urapolkuihin. Teemoja oli kuusi: 1) informantin uratausta, 2) lumilautailun kehitys harrastuksesta vakavammin otettavaksi uraksi, 3) laskijan kiinnittyminen ammattilaisuuteen, 4) informantin työnkuvaus, 5) ammattilaisuuden paineet ja 6) lumilautailu- ja urataitojen oppiminen. Haastattelujen keruuprosessi oli itsessään mielenkiintoinen kuvaus lumilautailijoiden asenteista ja arjesta. Kysymysrunkoa ei ehditty käydä kaikissa haastatteluissa kattavasti läpi, sillä kaverit saattoivat hakea informantin rinteeseen kesken haastattelun tai haastattelua tehtiin informantin toiveesta haasteellisessa paikassa kuten baarissa. Jokainen haastattelu sisältää kuitenkin rikasta kerrontaa lumilautailijoiden tavoitteista.

Aineisto on analysoitu jäsentämällä lumilautailijoiden tavoitteita koodaten ja teemoitellen. Koodasimme aluksi haastatteluaineiston etsien siitä mahdollisimman paljon erilaisia uratavoitteita. Vaikka lähdimme aineistolähtöisesti liikkeelle, olemme tietoisia siitä, että koodauksessa ja teemoittelussa tutkijan katsetta ja tulkintaa ohjaa aina aiempi tuntemus tutkittavasta aiheesta (Braun \& Clarke 2006). Katseemme kohdistui koodausvaiheessa aineistossa säännönmukaisuuksiin, jotka koskivat lumilautailukilpailuja ja -mediatuotantoja (Ojala 2014), vapauden ja luovuuden pyrkimyksiä (Hänninen 2007; Ojala 2014; Humphreys 2003) sekä tyylillistä, kielellistä ja taidollista erottautumista (Thorpe 2011, 115-138; Hänninen 2012). Olemme jättäneet aineistosta urheilulajin paremman hallitsemisen tavoitteena huomioimatta, sillä oletamme sen olleen urheilijoilla tautologisena tavoitteena kautta aikojen heidän urheilu-urillaan. Lisäksi jätimme ulkopuolisten toimijoiden (kilpailuorganisaation, sponsorien, mediayhtiöiden) hyödyttämistä koskevat tavoitteet artikkelin tiukasti rajatun koon vuoksi raportoimatta. Vertasimme löydöksiämme aiempiin tutkimuksiin 
modernien urheilukulttuurien tavoitteista. Modernista urheiluperinteestä poikkeavia tavoitteita tarkastelimme Pushkala Prasadin (2005, 211-239) ja Steven Seidmanin (1994) tutkimuksissaan kokoamien, jälkimodernille ajalle tyypillisiksi tulkittujen aatteellisten virtausten valossa.

Lumilautailun kehitys urheiluna ja nuorisokulttuurin.

Nykylumilautailun juuret juontavat 1960-1970-luvun Yhdysvaltoihin ja siellä vallinneeseen vaihtoehtoilmapiiriin, jossa liikkumista kehitettiin perinteisestä kilpaurheilusta poikkeavaksi ruumiinkulttuuriksi (Thorpe \& Wheaton 2011, 831). Uusissa liikkumismuodoissa arvostettiin muuhun kilpaurheiluun liittyvän totisuuden ja suorittamisen sijasta luovuutta, hauskuutta, harrastajalähtöisyyttä, vapautta ja itseilmaisua (Wheaton 2004, 9-12). Nämä nuorisokulttuurisen liikkumisen eetokseksi kutsutut aatteet (Gilchrist \& Wheaton 2011, 111; Ojala 2014) saivat voimaa 1960-1980-lukujen beat- ja punk-ideologioista (Humphreys 2003, 412-413).

Lumilautailua kuitenkin kehitettiin alusta alkaen systemaattisesti myös vakavasti otettavan urheilun suuntaan. Sherman Poppenin Michiganissa 1960-luvun puolivälissä kehittämät suositut lumilelut houkuttelivat lisää lumilautojen kehittelijöitä, joista osa näki modernin urheilukulttuurin mahdollisuutena lumilautailulle. (Thorpe 2011, 21-22, Howe 1998, 9-11). Kalifornian skeittikulttuurista lajin pariin tulleet harrastajat kuitenkin vierastivat lumilautailun urheilullistamista ja kehittivät lajia selvästi nuorisokulttuurisempaan suuntaan (Howe 1998, 39-52).

Ensimmäiset lumilautaorganisaatiot perustettiin 1980-luvun puolivälissä. Paikallisemmat lumilautailuorganisaatiot koottiin vuonna 1991 yhdeksi kansainväliseksi kattojärjestöksi, International Snowboarding Federationiksi (ISF). (Humphreys 2003, 409.) Lumilautailukilpailuista muodostui nuorisokulttuurisia käytäntöjä välittäviä juhlia, joissa imettiin uusia vaikutteita ja pidettiin hauskaa (ks. Howe 1998, 55). Sosiaalistumisympäristönä lumilautailu poikkesi siis merkittävästi saman aikakauden edustamiseen ja tuloksellisuuteen tähdänneestä kilpaurheilusta (ks. Heinilä 1974, 11).

Yhtä aikaa organisaatioiden kanssa perustettiin ensimmäiset lumilautailulehdet ja tuotettiin lumilautafilmit, joita rahoittivat kasvavasta lajista innostuneet lumilautailuyritykset. (Howe 1998, 103-104.) Erikoismedian rooli oli alusta alkaen merkittävä: se välitti harrastajille tietoa lumilautailukulttuurin trendeistä ennen kuin valtavirtamedia oli kiinnostunut lajista (Ojala 2014, 106). Nämä trendit tarjosivat nuorisokulttuurisia aineksia lumilautailijoiden identiteettien rakentamiseen. Lumilautailun ensivuosikymmenien kulttuurihistorian kirjoittanut Susanna Howe $(1998,107)$ kuvaakin, että valo- ja filmikuvaajista tuli nopeasti lumilautateollisuuden imagon tekijöitä. Erikoislehdet, -videot ja nettijulkaisut mahdollistavat nykyäänkin modernin kilpaurheilun toimintatapojen haastamisen osana nuorisokulttuurista liikkumista (Ojala \& Itkonen 2013). Suomalaisessa mediassa lumilautailu esiintyi ensimmäistä kertaa vuonna 1984 (Hänninen 2012, 19). Neljä vuotta myöhemmin Suomeen perustettiin jo lumilautaliitto (Areng \& Willners 1995, 14).

Kansainvälinen Olympiakomitea (KOK) kiinnostui 1990-luvun alussa nuoria innostavasta lajista ja nimitti Kansainvälisen Hiihtoliiton (FIS) lumilautailun vastuuorganisaatioksi olympia-areenoille. Lumilautailijat vastustivat FISiä ja kannattivat äänekkäästi omaa lajiorganisaatiotaan. Olympiakomitean kiinnostus nuorisokulttuurisista lajeista ei ollut yllätys, sillä olympialaisten viehätys nuorten yleisöjen parissa oli laskenut selvästi. (Thorpe \& Wheaton 2011, 833-837.) Olympialaiset vauhdittivat kilpalumilautailun kehitystä kohti ratoja ja lajeja normittavia sääntöjä sekä kansallisuuksien edustamista.

Lumilautailijoiden vastareaktio olympiaurheilulle oli 2000-luvun alussa perustettu Ticket to Ride -organisaatio (TTR). Se korvasi vanhat lumilautailun kattojärjestöt ja liitti erilli- 
set kilpailut osaksi lumilautailun suurinta kiertuetta, World Snowboard Touria (WST). Lumilautailun normittumista on pyritty välttämään TTR:n sertifioimissa kilpailuissa muun muassa siten, että luovuuden säilymistä on tuettu vastustamalla vakiintuneiden kilpailuratojen käyttöönottoa (ks. Deschenes s.a.).

Vaihtoehtoisista kilpailukiertueista huolimatta kilpalumilautailun sosialisaatioympäristö voidaan tulkita modernin urheilukulttuurin jatkeeksi. Kilpailumenestykseen tähdätään keinoin, jotka normittavat lumilautailua nuorisokulttuurina. Kilpailut sääntöineen, kilpailuorganisaatioineen ja tiettyyn lumilautailumuotoon erikoistuneine lumilautailijoineen edustavat modernin ajan sivilisoitumispyrkimyksiä ja perinteistä urheilukulttuuria. Myös valmennusjärjestelmä kantaa modernin aikakauden perinteitä mukanaan. Lumilautailu on kehittynyt kilpailutoimintansa osalta nuorisokulttuurisuuden muodoksi, johon on muodostunut pysyvämpiä organisointikäytäntöjä sekä sääntöjä, jotka myös ohjaavat urheilijoiden tavoitteita (Ojala 2014; Booth \& Thorpe 2007, 185-188).

Lumilautailun tavoitteiden kulttuuriset merkitykset

Haastatteluaineistosta on tiivistettävissä toistuvia, tavoitteita koskevia kulttuurisia merkityksiä, jotka ovat kiteytettävissä kuudeksi erillisteemaksi. Nämä ovat: 1) kilpailumenestys, 2) totisuuden haastaminen ironialla, 3) pyrkimys urheilukulttuurin esittelyyn mediatuottein, 4) tavoite lumilautailusta nauttimiseen menestyksestä välittämättä, 5) pyrkimys uravalintojen vapauteen sekä 6) halu olla muiden silmissä ennen muuta "hyvä tyyppi". Seuraavaksi nämä lumilautailijoiden itsensä esiintuomat kulttuuriset merkitykset esitellään edellä luetellussa järjestyksessä.

Kuten Ojala (2014) on osoittanut tutkimuksessaan, lumilautailijat keskittyvät yleensä joko kilpailemiseen tai kuvaamiseen, ja usein kuvaaminen on suomalaisille lumilautailijoille ollut kilpailemista mielekkäämpää. Vain kaksi tämän artikkelin haastatelluista lumilautailijoista halusi toteuttaa uraansa pelkästään kilpailemalla. Näin kansainvälisissä kilpailuissa erittäin hyvin menestynyt lumilautailija selvensi omaa suhdettaan kilpailuihin kertomalla, että sitä kautta saattoi päästä kuvauksiin:

Justii oltii tuol Japanissa ja joku kysy sitä et miten niinku, et miks te valitsitte ton kisapuolen ettekä niinku sit kuvausta, ja mä vaa vastasin siihen että, et emmä oo sitä oikeestaa ikinä valinnu, että jotenki, siis kyllä mua kiinnostais lähtee just kuvaamaa ja tehä tommossii mutta, jotenki sillon justiisa nuorempana se oli niin helppo ku ties et tuol on kisat et mennää sinne, et sielt saa, et jos siel pärjää ni saa sit vähän nimee ja sitä kautta voi saada sit just jotain kuvausjuttui, mut, mut tota. Enhän mä nyt tiedä, nythän pitää olla sit aika paljon jotain suhteita sit jos haluu johonki leffoihin ja tälläsiin. (14.11.2010, mies.)

Lumilautailijoiden mediatuotantoihin liittyviä tavoitteita tarkastelemalla voidaan huomata, että jälkimoderniin tapaan median ja urheilun alueet sekoittuvat hyvin vahvasti (Seidman 1994, 2), eikä liikkumiskäytäntöjä ole enää helppo erottaa mediakäytännöistä. Edellisestä esimerkistä voidaan myös havaita, miten nuorisokulttuurisen liikkumisen mediatuotannot eivät rakennu formaaleille säännöille tai urheiluorganisaatioiden toiminnalle, vaan ne organisoituvat sangen epämuodollisesti. Näin organisoituva sosiaalistumisympäristö ei ole kuitenkaan säännöiltään vapaa, vaan sääntöjä ylläpidetään epämuodollisesti ryhmän sisällä. Lumilautailijat tarvitsevatkin kulttuurista tietoa kuhunkin lumilautailutyyliin ja ryhmään hyväksyttävistä käytännöistä ja ajatusmalleista. Lisäksi heillä pitää olla edellisessäkin esimerkissä mainittuja suhteita päästäkseen mukaan vapaasti organisoituviin mediaproduktioihin, sillä ne eivät perustu modernin urheilujärjestelmän kaltaisille valmiille reiteille. (Ojala 
2014, 117-119.) Edellisestä esimerkistä käy ilmi, miten kilpailuihin keskittyvät lumilautailijat toivoivat saavuttavansa menestystä varsinkin suurimmissa kutsukilpailuissa, kuten mediayhtiö ESPN:n järjestämissä X Games -kilpailuissa. On kiinnostavaa, miten nämä maininnat saattoivat olla kuin sivuhuomautuksia uralla: "Pitäis yrittää päästä Japanin kisoihin" (15.11.2010, mies)

Olympialaiset oli aihe, joka sai monen haastatellun lumilautailijan tunteet kuumenemaan. Monet ovat innoissaan päästessään mukaan valtavirtayleisön arvostusta nauttiviin kilpailuihin, kuten seuraavasta esimerkistä voi tulkita: "No viimevuonna olympialaisissa, sillon jännitti . . . Ja sit ku pääs sinne semifinaaleihin ni sillon tuntu jo ihan sikahyvältä . . . mut sit ei saanu siihen finaalii kerättyy enää itteesä, mutta . . . kyl mä oon ihan tyytyväinen siihen" (14.11.2010, mies). Kuitenkin aineistostamme oli myös tulkittavissa, ettei osa kilpailuja käyvistä lumilautailijoista halua kilpailla olympialaisissa, vaan kokee kisojen pakottaneen lumilautailun tiettyyn muottiin sekä tappaneen lajin luovuuden ja olosuhteiden muuntelun: "Ei lumilautailu oo koskaan ollu mulle silleen, mul ei oo ikinä ollu ketään joka on kertonu mulle et mee hyppään tosta, toi on nyt ihan eri juttu toi maajoukkue ja olympiameiniki et, mä en pysty siihen samaistuun millään" (5.11.2010, mies).

Luovuuden puolustaminen olikin lumilautailijoille erityisen tärkeä seikka, mikä tuli monessa haastattelussa painavasti esille. Monipuolisuutta ja muuttuvuutta haluttiin vaalia, kuten seuraavasta haastattelusta voi tulkita: "Vähän liianki usein on semmoset niinku ennalta arvattavat [kilpailuradat], et ne tietää mitä siel tulee olee . . . mun mielestä ei pitäis asettaa jotain rajoja sille, vaan tehä mahollisimman monipuolisesti kaikkia asioita ois paras" (6.11.2010, mies). Pohdimmekin, josko pyrkimys luovuuteen olisi ollut syytä nostaa yhdeksi lumilautailijoiden tavoitteita kuvaavaksi teemaksi. Tulkitsimme pyrkimyksen luovuuteen kuuluvan lopulta samaan teemaan, johon liittyy pyrkimys vapauteen, jota käsittelemme myöhemmin tässä luvussa.

Kertoessaan itselleen tärkeistä kilpailutavoitteista ja saavutuksista lumilautailijat toisinaan palauttivat niiden merkityksen nuorisokulttuuriin ironisoimalla totisuutta: "Jos pääsee semeihin [semifinaaliin] ni saa rannekkeen loppubileisiin" (2.4.2011, mies). Ironian muodot viittasivat nuorisokulttuurille legitiimeihin toimintamalleihin, kuten juhlimiseen tai palkintorahojen käyttämiseen vertaisyhteisöä palvelevalla tavalla. Tämänkaltainen puhe sopii osaksi nuorisokulttuuriin liittyvää identiteetin työstämistä sellaisessa ympäristössä, joka periaatteessa edustaa aikuisten kilpaurheilukulttuuria. Käytäntöjen merkitystä muutetaan niin, että se sopii omaan kulttuuriseen identiteettiin (Sahlin \& Wedlin 2008, 225).

Aina kilpailuihin tähtäävät nykylumilautailun toimintamallit eivät taipuneet haastattelemiemme lumilautailijoiden tulkinnoissa heidän nuorisokulttuuriinsa sopivaan muotoon. Yksi esimerkki nuorisokulttuurin ja urheilukulttuurin kohtaamisesta ilmeni haastattelussa kahden mieslumilautailijan kanssa. He olivat muuttaneet Vuokattiin käydäkseen ammattikoulua ja osallistuakseen urheiluakatemian toimintaan. He naureskelivat valmennuksen tavoitteellisuudelle ja käytännöille esimerkiksi seuraavanlaisesti:

i1: Ne treenit aina mitä ne vetää välillä ni ne menee hiihtoliiton treenien puolelle.

i2: Joo menee vähän niinku, asian, vittu, ytimestä ohi.

i1: Ensvuonna on tulos sillee et siel on kolme ryhmää . . kehittyjät, haastajat ja sitte pro ryhmä. [naurua] Et meijät jaettais niinku ryhmii! 


\title{
i2: Joo siel jaetaan joihinki ryhmii niinku laskijat tai jotain vit- ihan älytöntä. (2.4.2011, 2 miestä)
}

Näille normatiivisille ryhmäjaoille lumilautailijat saattoivat vain naureskella. Käydessään koulua Vuokatissa lumilautailun ehdoilla he alistuivat kilpailuihin tähtäävään valmennustoimintaan, joka ei sopinut heidän näkemykseensä lumilautailulle sopivista käytännöistä.

Kilpailu- ja kuvaamissaavutusten lisäksi lumilautailuun sisältyy normi sellaisesta tavoitteellisuudesta, jossa itse lumilautailusta nauttiminen on uran korkein päämäärä. Aineistossa tämä tuli esiin useissa toteamuksissa, joissa lumilautailusta nauttimista verrattiin ulkoisiin saavutuksiin ja todettiin intohimon jatkuneen niistä huolimatta:

\begin{abstract}
Sitä on vaikea selittää, mie vaan tykkään siitä niin paljon, siis ei mun- meikä menee kotonaki laskee vaikka rinnettä, ei sillä oo mitään väliä . . . se on sellanen asia jota niinku, joka on niin iso elämää ja siitä on aina tykänny ni ei se oo muuttunu mihinkää siitä, että vaikka kuinka paljon ois tullu rahaa ja sopimuksia ja pärjänny kisoissa ni ei mun katsomus sillee niinku siitä että kuin mukavaa se on ni oо muиttunu. . . Se rakkaus siihen lajii, se ei oо muиttunu ikinä, ja se on tärkeintä, koska monille ihmisille se muuttuu bisnekseksi, mie tiedän myös niitäki nimeltä mainitsemattomia, joille se munttuu täydeks bisnekseks ... että ku niillä loppuи diilit [sponsorisopimukset], ni ne kertoo jossaki, että nyt meikä lopettaa, ja se on ihan naurettavaa, ei se oo mitään helvetin jääkiekkoa et siitä pitää kertoa et lopettaa, meikästä se on niin että vitsi, jos oikeesti tykkää jostakin lajista ni sie teet sitä koko sun elämäs, niin paljon ku mahollista. (6.11.2010, mies)
\end{abstract}

Edellisestä esimerkistä voi tulkita, että lumilautailijat myös kritisoivat toisten lumilautailijoiden tavoitteita vahvoin ilmauksin, etenkin, jos toiset eivät osoita lumilautailun motiiviksi omaa nautintoaan. Esimerkistä voi tulkita myös lumilautailijoiden tavan luoda identiteettiä erottautumalla modernista urheilusta, mikä tässä yhteydessä tapahtui vertaamalla lumilautailua jääkiekkoon ja aiemmassa esimerkissä vertaamalla hiihtoon. Alakulttuureita tutkineen sosiologi Sarah Thortonin mukaan ihmiset vahvistavatkin omaa identiteettiään erottautumisen kautta, sillä erottautuminen jostain on yksinkertaisempaa kuin kuulumisen osoittaminen johonkin $(2005,118)$.

Intohimoa lajiin käytetään argumenttina hetkille, jolloin tekemisessä ei tunnu olevan mitään järkeä tai kun lumilautaileminen vaatii suuria riskinottoja. Seuraava esimerkki (5.11.2011) kuvaa yhden lumilautailijan suhtautumista riskinottoon, joka kuitenkin perustellaan lumilautailusta nauttimisella:

Mua ei haittaa ollenkaa vaik lähtis vittu henkiki, et se on mitä mä teen. Mä diggaan siit niinku niin vitusti! Et, kyl niinku, sillai ku vetää niit putskuhyndiiki [hyppyreitä pehmeässä lumessa] ni kylhä niihinki tulee niit reikii alastuloihin ja sä et todellakaan haluu tulla niihin, mut kyl meitsi haluu vaan tätä niin paljon et räiskii viel sinne ihan tyhmästi sillai, et kyl tästä voi käydä viel huonostiki ... et se oo niinku tää laji. Aina käy.

Lajista nauttiminen on niin vahva normi lumilautailukulttuurissa, että sen ympärille kyetään rakentamaan tavoitteen saavuttamisesta kertovia narratiiveja, kuten riskien ottaminen nautinnon vuoksi.

Kuten aiemmissa tutkimuksissakin on todettu, tavoittelevat lumilautailijat myös vapauden kokemuksia (esim. Hänninen 2007, 4-5; Ojala 2014, 115-119; Humphreys 2003). 
Tähän teemaan liitämme myös puheen luovuudesta, joka tässä aineistossa kytkeytyi tavoitteisiin vapaudesta valita suoritusolosuhteensa, temppunsa ja ilmaisutyylinsä. Lumilautailua tutkineen Riitta Hännisen mukaan lajissa on vapaus ja jopa velvollisuus "valita oma tapansa olla lumilautailija" (2007, 14). Tähän vapauden tavoitteeseen liitämme haastateltujen puheen suunnitelmistaan kilpailla tai kuvata, kuten seuraavan haastatteluesimerkin:

\begin{abstract}
No, mä en oikee tiiä, kyl mä siis toden näkösesti tuun enemmän kuvaa, mut emmä koskaa tuu sellai et pelkästää kuvaisin, et kisat on, siis just sillaii et kävis kaudes jonku verran kisoja ja sit jos sais kuvattuuki jotain ni se ois siistii . . . mut tota en niinku tosiaankaa sitä koko kautta just et, mä en haluu sitäkää et koko kauden kuvaa ja sit se on tommost, emmä tiiä onks se niin hauskaa, et, se on muutenki aina kauden jossain vaihees siistii et pääsis vaan laskee ihan, ei ois mitään kuvauksii tai kisoi, et pääsis vaa laskee ihan itelle. (15.11.2010, mies.)
\end{abstract}

Vapaus valita kilpailemisen ja kuvaamisen välillä liittyy myös mielestämme jälkimoderniin aikaan. Valinnanvapaus ei ole kaikille lumilautailijoille kuitenkaan yhtäläinen mahdollisuus. Aineistomme kahden naislumilautailijan mukaan mahdollisuuksien kenttä on heillä suppeampi kuin miehillä. Kilpailuista saatavat palkintosummat saattavat olla niin paljon pienempiä, että niihin osallistumista punnitaan tarkasti vaikka menestystä voisi olla tiedossa: "Just ku oli noi Pleasure Jamit, ni siellä se on aika iso se palkintojen ero. . . se on niinku plus miinus nolla. Et ei siitä niinku hirveesti jää voitolle.” (15.11.2010, nainen). Samaan valintamahdollisuuksien näennäisyyteen kuuluu se seikka, että jotkut lumilautailijat haluaisivat ottaa osaa lumilautailukuvauksiin enemmän, mutta heillä ei ollut siihen vaadittavia resursseja.

Vaikka kaikilla lumilautailijoilla ei ole samanlaisia valinnan mahdollisuuksia, ovat kuviteltavissa olevat mahdollisuudet lisääntyneet moderniin urheilukulttuuriin verrattuna. Tämä näkemys sopii sosiologi Zygmunt Baumanin kuvaukseen ihmisten muotivirtausten kaltaisista identiteettiprojekteista muuttuvaisella jälkimodernilla ajalla $(2004,85)$. Valintojen keskellä identiteettiä on työstettävä. Jokaisen lumilautailijan odotetaan valitsevan omannäköisensä uran (Hänninen 2007, 14). Lajikulttuurissa vallitsevat arvot määräävät kuitenkin legitiimejä tavoitteita. Tämä tarkoittaa esimerkiksi sitä, että lumilautailusta on osattava nauttia, vaikka siltä ei aina tuntuisikaan, sillä nauttiminen on lumilautailijuuteen kuuluva tavoite.

Hyvän jätkän normi ei tullut aineistossa esiin niinkään suorasti ilmaistuna tavoitteena, vaan yleisinä mainintoina sellaisista lumilautailijoista, jotka pääsevät tavoitteisiinsa sosiaalisten taitojensa ja ulospäinsuuntautuneisuutensa vuoksi. Sosiaalisten taitojensa vuoksi arvostettu lumilautailija ei ollut missään nimessä liikanimi sellaiselle lumilautailijalle, joka ei osannut lumilautailla, kuten seuraavasta esimerkistä ilmenee: 'Kyllähän se on niinku jos on semmonen sosiaalinen tyyppi, ni onhan se nyt helpompi semmosen kans niinku toimia ja oppia tunteen se . . . että joko pitää olla ihan helevetin hyvä laskeen tai sitte pitää olla mukava jätkä" (13.11.2010, mies). Sosiaaliset taidot koetaan tärkeinä tavoitteina lumilautailun kaltaisessa sosiaalistumisympäristössä siitä syystä, ettei lumilautailu ole modernin urheilun tavoin organisoitunut pelkästään urheiluorganisaatioiden varaan. Mediatuotannot vaativat suhteita, kuten esimerkki haastattelustamme aiemmin kuvasi. Vapaamuotoisesti organisoituvassa ja nopeasti muuttuvassa lumilautailussa sosiaaliset siteet merkitsevät enemmän kuin sellaisissa urheilun sosiaalistumisympäristöissä, joissa menestyminen riippuu pelkästään urheilutuloksista. 
Tätä teemaa voi kutsua hyvän jätkän normiksi siitä syystä, että maskuliiniseksi osoitetussa lumilautailukulttuurissa miehiset toimintamallit luonnollistuvat herkästi. Sosiaaliseen toimintaan kuten taitojen kehittymiseenkin liittyvät huomiot saavat miesten tekotapoja noudattelevia ihanteita, mikä on ollut urheilussa tavallista kautta aikojen. (Thorpe 2011, 139147.) Maskuliinisuus näkyi aineistossamme esimerkiksi seuraavanlaisena ilmaisuna: "Muijil on vaan niin muijatyyli ja muijatrikit, et ei se vaan oo mahollista et ne tekee samallaisii trikkei [temppuja] ku jätkät, emmä osaa selittää sit enempää.” (5.11.2010, mies).

\section{Johtopäätökset}

Tässä artikkelissa on tarkasteltu lumilautailukulttuurin tavoitteita koskevia normeja suhteessa modernien urheilukulttuurien vastaaviin. Lumilautailu edustaa tutkimuksessamme nuorisokulttuuriseksi liikkumiseksi luokiteltavaa ruumiinkulttuuria. Lumilautailu ei ole jäänyt mitenkään poikkeavaksi tai irralliseksi saarekkeeksi urheilun yleisessä modernisoitumiskehityksessä. Lumilautailukilpailut vakiintuneine formaatteineen ja urheiluorganisaatioineen sekä kilpailemiseen keskittyvine tavoitteineen ovat tyypillisiä esimerkkejä modernin aatemaailman mukaisesta urheilun sosialisaatioympäristöstä. Ilmiönä nuorisokulttuurinen liikkuminen on hyvä esimerkki jälkimodernin ajan ominaispiirteistä. Nuorisokulttuuristen lajien monimuotoisuus ja muuttuvaisuus tarjoavat mahdollisuuksia jälkimodernien nuorten identiteetinrakentamiseen. Jälkimoderniin aikaan sopivasti lumilautailijat myös karttavat perinteisten urheilulajien totisuutta ironisoiden sen tavoitteellisuutta kilpailuissa. Lisäksi lumilautailijat haastavat moderneja urheilukulttuureita esittelemällä taitojaan kilpailuiden sijasta mediatuotteiden välityksellä, asettamalla lumilautailusta nauttimisen kilpailuvoittoja tai mediamenestystä korkeammaksi saavutukseksi sekä pyrkimällä oman näköiseen uraan ja sosiaaliseen kyvykkyyteen.

Artikkelimme osoittaa, miten nuorten maailma on jälkimodernina aikana täynnä erilaisia elämäntapoja ja -tyylejä, jolloin yhtenäisille näkemyksille, kokemuksille ja uskomuksille ei ole edes urheilukulttuurissa enää samalla tavalla tilaa kuin ennen. Tavoitteista on uusissa urheilukulttuureissa monia erilaisia versioita, jotka toisinaan kilpailevat keskenään, mutta yleensä vain hyväksyvät toistensa yhtäaikaisen olemassaolon. Sosialisaatioympäristönä nuorisokulttuuriset liikkumismuodot tarjoavat siis moderneihin urheilukulttuureihin verrattuna enemmän valinnanvaraa, mutta myös epäselvyyttä normeista, sillä tavoitteet ja säännöt eivät ole selkeitä ja muuttumattomia. Nuoren tulee kyetä tulkitsemaan sitä, mikä kulloinkin on hyväksyttyä ja tavoiteltavaa. Kaikilla ei kuitenkaan ole täysin yhtäläisiä mahdollisuuksia valintojen tekemiseen. Toisaalta lajien monimuotoisuus antaa nuorille mahdollisuuden nähdä urheilu-uran onnistumiseen liittyvät saavutukset laajemmin kuin moderneissa urheilulajeissa. Nuorisokulttuuriset liikkumismuodot eivät näyttäisi tulkintamme mukaan vaativan harrastajilta ehdotonta suorituskeskeisyyttä edes huipputasolla. Myös nauttimisen osoittaminen, omien polkujen löytäminen ja sosiaaliset taidot tarjoavat hyväksyntää vertaisten keskuudessa.

Myös lumilautailukilpailuihin osallistuvien nuorten asenteissa on nähtävissä sellaisia nuorisokulttuurisuuden muotoja, jotka sopivat hyvin jälkimodernille ajalle ominaiseen ja perinteisestä urheilukulttuurista poikkeavaan populaarin ja elitismin rajan hämärtymiseen ja hämärryttämiseen. Jälkimoderniin sopivasti lumilautailijat haastoivat kilpailukäytäntöjen totisuutta hauskanpidolla ja ironialla (ks. Prasad 2005, 219-220). Näistä löydöksistä huolimatta lumilautailun kehitystä ei voi tulkita täysin modernisoitumiskehityksestä erillisenä. Vaikka perinteiset urheilutraditiot ovat monelta osin murtuneet jälkimodernin ajan nuoriso- 
kulttuureissa, on vapautuminen sangen rajallista toimittaessa modernin ajan instituutioiden, kuten koululaitoksen tai perinteisten urheiluorganisaatioiden alaisuudessa.

Kun vertaa tämän artikkelin löydöksiä Mikko Salasuon ja Anni Ojajärven (2014) tutkimukseen poikien fyysisen aktiivisuuden muutoksista sadan vuoden ajalla, voi havaita, että nuorisokulttuurinen liikkuminen tarjoaa nuorille liikkumisen sosiaalistumisympäristöjä, joissa nuoret voivat ottaa riskejä ja toteuttaa itseään ilman vanhempien valvontaa. Kun Salasuon ja Ojajärven tutkimille nykynuorille liikunta oli aiemmista sukupolvista poiketen pakon tai vapaaehtoisuuden sijaan vanhempien säätelemä sosiaalistumisympäristö, näyttävät nuorisokulttuurisen liikkumisen sosialisaatioympäristöt nykyään perin omaehtoisilta. Jatkossa onkin syytä kysyä, johtuuko nuorisokulttuurisen liikkumisen viehätys juuri sosiaalistumisympäristöjen omaehtoisuudesta?

\section{Lähteet}

\section{Haastattelut}

Kahdenkymmenenyhden suomalaisen ammattilaislumilautailijan ja puoliammattilaisen teemahaastattelut, jotka Anna-Liisa Ojala teki marraskuun 2010 ja helmikuun 2012 välillä Skiexpo-messuilla, epävirallisilla maajoukkueleireillä sekä lumilautailutapahtumissa Suomessa ja Oslon maailmanmestaruuskilpailuissa.

\section{Digitaaliset lähteet}

Deschenes, Nate s.a. Terje [www-lähde]. < http://snowboardmag.com/stories/the-olympicissue-terje-haakonsen-interview $>$ (Luettu 15.9.2014).

\section{Kirjallisuus}

Aarresola, Outi \& Konttinen, Niilo 2012. Vanhemmat moni-ilmeinen vaikuttaja kilpaurheiluun sosiaalistumisessa. Liikunta \& Tiede 49 (6), 29-35.

Areng, Saga \& Willners, Martin 1995. Lumilautailu. Porvoo, Helsinki \& Juva: Werner Söderström.

Antikainen, Ari 1992. Kasvatus, koulutus ja yhteiskunta. Porvoo: WSOY.

Antikainen, Ari 1998. Kasvatus, elämänkulku ja yhteiskunta. Porvoo: WSOY.

Bauman, Zygmunt 1996. Postmodernin lumo. Tampere: Vastapaino.

Bauman, Zygmunt 2004. Identity: conversations with Benedetto Vecchi. Cambridge: Polity Press.

Booth, Duncan \& Thorpe, Holly 2007. The Meaning of Extreme. Teoksessa Booth, Douglas \& Thorpe, Holly (toim.) Berkshire Encyclopedia of Extreme Sports. Great Barrington, MA: Berkshire, 181-197.

Braun, Virginia \& Clarke, Victoria 2006. Using thematic analysis in psychology. Qualitative Research in Psychology 3 (2), 77-101.

Dunning, Eric 1999. Sport matters: sociological studies of sport, violence, and civilization. London: Routledge.

Giddens, Anthony 2009. Sociology, 6. painos. Cambridge: Polity Press.

Gilchrist, Paul \& Wheaton, Belinda 2011. Lifestyle sport, public policy and youth engagement: examining the emergence of parkour. International Journal of Sport Policy and Politics, 3 (1) 109-131. 
Heinilä, Kalevi 1974. Urheilu - ihminen - yhteiskunta. Jyväskylä: Gummerus.

Humphreys, Duncan 2003. Selling out snowboarding: the alternative response to commercial co-optation. Teoksessa Robert E. Rinehart \& Synthia Sydnor (toim.) To the extreme: Alternative sports, inside and out. New York, NY: State University of New York Press, 407-428.

Howe, Susanna 1998. (Sick): a cultural history of snowboarding. New York: St. Martin's Griffin.

Hänninen, Riitta 2007. Vapauden merkitys lumilautakulttuurissa. Elore 14 (2), 1-19 [wwwlähde]. < http://www.elore.fi/arkisto/2 07/han2 07.pdf $>$ (luettu 22.11.2014).

Hänninen, Riitta 2012. Puuterilumen lumo: tutkimus lumilautailukulttuurista. Väitöskirja, Jyväskylän yliopisto, Jyväskylä Studies in Humanities 191.

Itkonen, Hannu 1996. Syöksy Sivakkaan. Kylän ruumiillisuutta jäljittämässä. Teoksessa Knuuttila, Seppo \& Liikanen, Ilkka \& Rannikko, Pertti \& Itkonen, Hannu \& Koistinen, Merja \& Oksa, Jukka \& Vakimo, Sinikka (toim.) Kyläläiset kansalaiset. Tulkintoja Sivakasta ja Rasimäestä. Joensuun yliopisto. Karjalan tutkimuslaitoksen julkaisuja 114, 127-156.

Itkonen, Hannu 2003. Nuorisourheilun muuttuvat käytännöt, tavoitteet ja merkitykset. Teoksessa Aapola, Sinikka \& Kaarninen, Mervi (toim.) Nuoruuden vuosisata: suomalaisen nuorison historia. Helsinki: Suomalaisen Kirjallisuuden Seura, 327-343.

Itkonen, Hannu 2012. Nuorten liikkumisen muuttuvat muodot, tilat ja tavoitteet. Teoksessa Ilmanen, Kalervo \& Vehmas, Hanna (toim.) Liikunnan areenat: yhteiskuntatieteellisiä kirjoituksia liikunnasta ja urheilusta. Jyväskylän Yliopisto, Liikuntakasvatuksen laitos, tutkimuksia 1/2012, 157-174.

Itkonen, Hannu \& Simula, Mikko 2008. Kylä liikkumisen tilana - Sivakan lämpimät kiireet. Teoksessa Knuuttila, Seppo \& Rannikko, Pertti \& Oksa, Jukka \& Hämynen, Tapio \& Itkonen, Hannu \& Kilpeläinen, Heidi \& Simula, Mikko \& Vakimo, Sinikka \& Väisänen, Marjaana (toim.) Kylän paikka. Uusia tulkintoja Sivakasta ja Rasimäestä. Helsinki: Suomalaisen Kirjallisuuden Seura, 173-206.

Itkonen, Hannu, Salmikangas, Anna-Katriina \& Simula, Mikko 2010. Liikkumisen sosialisaatio kolmessa kylässä. Tutkimus Matovaaran, Nakertaja-Hetteenmäen ja Sivakkavaaran liikkumiskulttuurien muutoksista. Kasvatus ja Aika 4 (2), 69-82 [www-lähde]. < http://www.kasvatus-ja-aika.fi/site/?page id=266Hannu $>$ (luettu 24.11.2014).

Kokkonen, Jouko 2008. Kansakunta kilpasilla: Urheilu nationalismin kanavana ja lähteenä Suomessa 1900-1952. Helsinki: Suomalaisen Kirjallisuuden Seura.

Lindfelt, Mikael 2010. Elite sports in tension: making identification the core moral norm for professional sports in the future. Sport in Society 13 (2), 186-198.

Loy, John W., McPherson, Barry D. \& Kenyon, Gerald 1978. Sport and social systems. A guide to the analysis, problems, and literature. Reading, MA: Addison-Wesley.

Mouzelis, Nicos P. 2008. Modern and postmodern social theorizing: bridging the divide. Cambridge: Cambridge University Press.

Ojala, Anna-Liisa 2014. Institutionalisation in professional freestyle snowboarding - Finnish professional riders' perceptions. European Journal for Sport and Society 11 (2), 103-126.

Ojala, Anna-Liisa \& Itkonen, Hannu 2013. Median merkitys nuorisokulttuurisessa liikkumisessa. Nuorisotutkimus 31 (4), 20-35.

Prasad, Pushkala 2005. Crafting qualitative research: working in the postpositivist traditions. Armonk: M.E. Sharpe. 
Raiskio, Kaj 2005. Joka ei ole kanssamme on meitä vastaan: tehdasurheilu ja kontrolli Valkeakoskella. Taidetta ja tehdasurheilua, Suomen Urheiluhistoriallisen Seuran vuosikirja. Jyväskylä: Ateena Kustannus, 13-26.

Scott, William Richard 2001. Institutions and organizations, 2. painos. Thousand Oaks, CA: Sage.

Sahlin, K. \& Wedlin, L. 2008. Circulating ideas: Imitation, translation and editing. Teoksessa Greenwood, Royston, Oliver, Christine, Sahlin, Kerstin \& Suddaby, Roy (toim.) The Sage handbook of organizational institutionalism. London: Sage, 218-242.

Salasuo, Mikko \& Ojajärvi, Anni 2014. Melkein sata vuotta poikien liikkumista - Elämäntapa ja fyysinen aktiivisuus neljän sukupolven lapsuudessa ja nuoruudessa. Kasvatus \& A ika 8 (1), 98-112 [www-1ähde]. < http://www.kasvatus-ja-aika.fi/site/? $\underline{\text { lan=1\&page } \mathrm{id}=609}>$ (luettu 24.11.2014).

Seidman, Steven 1994. Introduction. Teoksessa Seidman, Steven (toim.) The postmodern turn: new perspectives on social theory. Cambridge: Cambridge University Press, 1-23.

Thornton, Sarah 2005 [1995]. The social logic of subcultural capital. Teoksessa Gelder, Ken (toim.) The subcultures reader, 2. painos. London: Routledge, 184-192.

Thorpe, Holly 2011. Snowboarding bodies in theory and practice. New York: Palgrave Macmillan.

Thorpe, Holly \& Wheaton, Belinda 2011. 'Generation X Games', action sports and the Olympic movement: Understanding the cultural politics of incorporation. Sociology 45 (5), 830-847.

Tomlinson, Alan, Ravenscroft, Neil, Wheaton, Belinda \& Gilchrist, Paul 2005. Lifestyle sports and national sport policy: an agenda for research. Report to Sport England, March 2005.

Wagg, Stephen, Brick, Carlton, Wheaton, Belinda \& Caudwell, Jayne 2009. Key concepts in sport studies. London: Sage.

Wheaton, Belinda 2004. Understanding lifestyle sports: consumption, identity and difference. London: Routledge.

Wheaton, Belinda 2013. The cultural politics of lifestyle sports. Abingdon: Routledge.

Anna-Liisa Ojala, FM, YTM, liikunnan yhteiskuntatieteiden tohtorikoulutettava Jyväskylän Yliopistossa. Ojala valmistelee väitöskirjaa lumilautailijoiden urapolkuja raamittavista asenteista, olosuhteista ja resursseista Opetus- ja Kulttuuriministeriön rahoituksella.

Hannu Itkonen, YTT, liikuntasosiologian professori Jyväskylän yliopistossa. 